VILNIAUS GEDIMINO TECHNIKOS UNIVERSITETAS

Vytautas JOCIUS

\title{
CEMENTO TIPO, UŽPILDŲ IR ORO KIEKIO MIŠINYJE ITAKA BETONO ATSPARUMUI UGNIAI
}

DAKTARO DISERTACIJA

TECHNOLOGIJOS MOKSLAI, MEDŽIAGŲ INŽINERIJA (08T)

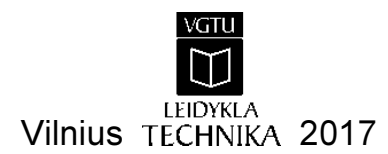


Disertacija rengta 2011-2017 metais Vilniaus Gedimino technikos universitete.

Vadovas

doc. dr. Gintautas SKRIPKIŪNAS (Vilniaus Gedimino technikos universitetas, medžiagų inžinerija - 08T).

Vilniaus Gedimino technikos universiteto Medžiagų inžinerijos mokslo krypties disertacijos gynimo taryba:

\section{Pirmininkas}

dr. Viktor GRIBNIAK (Vilniaus Gedimino technikos universitetas, medžiagu inžinerija - 08T).

\section{Nariai:}

dr. Diana BAJARE (Rygos technikos universitetas, medžiagų inžinerija - 08T), dr. Irmantas BARAUSKAS (Kauno technologijos universitetas, chemijos inžinerija - 05T),

dr. Marijonas SINICA (Vilniaus Gedimino technikos universitetas, medžiagų inžinerija - 08T),

prof. dr. Juozas VALIVONIS (Vilniaus Gedimino technikos universitetas, statybos inžinerija - 02T).

Disertacija bus ginama viešame Medžiagų inžinerijos mokslo krypties disertacijos gynimo tarybos posèdyje 2017 m. rugpjūčio 28 d. 14 val. Vilniaus Gedimino technikos universiteto senato posèdžių salèje.

Adresas: Sauletekio al. 11, LT-10223 Vilnius, Lietuva. Tel.: (8 5) 274 4956; faksas (8 5) 270 0112; el. paštas doktor@vgtu.lt

Pranešimai apie numatomą ginti disertaciją išsiųsti $2017 \mathrm{~m}$. liepos $18 \mathrm{~d}$. Disertaciją galima peržiūrèti VGTU talpykloje http://dspace.vgtu.lt/ ir Vilniaus Gedimino technikos universiteto bibliotekoje (Sauletekio al. 14, LT-10223 Vilnius, Lietuva).

VGTU leidyklos TECHNIKA 2017-044-S mokslo literatūros knyga http://leidykla.vgtu.lt

ISBN 978-609-476-042-6

(C) VGTU leidykla TECHNIKA, 2017

(C) Vytautas Jocius, 2017

vytautas.jocius@vgtu.lt 
VILNIUS GEDIMINAS TECHNICAL UNIVERSITY

Vytautas JOCIUS

CEMENT TYPE, AGGREGATES AND AIR CONTENT IN CONCRETE MIXTURE INFLUENCE ON THE FIRE RESISTANCE OF CONCRETE

DOCTORAL DISSERTATION

TECHNOLOGICAL SCIENCES,

MATERIALS ENGINEERING (08T)

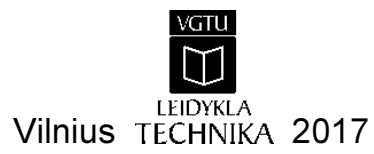


Doctoral dissertation was prepared at Vilnius Gediminas Technical University in 2011-2017.

\section{Supervisor}

Assoc. Prof. Dr Gintautas SKRIPKIŪNAS (Vilnius Gediminas Technical University, Materials Engineering - 08T).

The Dissertation Defence Council of Scientific Field of Materials Engineering of Vilnius Gediminas Technical University:

\section{Chairman}

Dr Viktor GRIBNIAK (Vilnius Gediminas Technical University, Materials Engineering - 08T).

\section{Members:}

Dr Diana BAJARE (Riga Technical University, Materials Engineering - 08T), Dr Irmantas BARAUSKAS (Kaunas University of Technology, Chemical Engineering - 05T),

Dr Marijonas SINICA (Vilnius Gediminas Technical University, Materials Engineering - 08T),

Prof. Dr Juozas VALIVONIS (Vilnius Gediminas Technical University, Civil Engineering - 02T),

The dissertation will be defended at the public meeting of the Dissertation Defence Council of Materials Engineering in the Senate Hall of Vilnius Gediminas Technical University at 2 p. m. on 28 August 2017.

Address: Saulètekio al. 11, LT-10223 Vilnius, Lithuania.

Tel.: +370 5274 4956; fax +370 5270 0112; e-mail: doktor@vgtu.lt

A notification on the intend defending of the dissertation was send on 18 of July 2017.

A copy of the doctoral dissertation is available for review on the VGTU repository http://dspace.vgtu.lt/ and at the Library of Vilnius Gediminas Technical University (Sauletekio al. 14, LT-10223 Vilnius, Lithuania). 


\section{Reziumè}

Betono atsparumas ugniai yra svarbus veiksnys pastatų konstrukcijų gaisrinei saugai, kuri apibrèžiama remiantis šiais kriterijais: $\mathrm{R}$ - geba atlaikyti konstrukciju apkrovas, E - atitikti (tenkinti) vientisumo ir I - izoliavimo charakteristikas nustatytą laiką gaisro metu. Šiuo metu projektuojant gelžbetoninių konstrukcijų atsparumą ugniai yra atsižvelgiama i apsauginio sluoksnio iki armatūros storį, tačiau nevertinamos betono, iš kurio pagaminta konstrukcija, eksploatacinès savybès ir sudedamosios dalys: cemento sudetis, užpildo charakteristikos ir betone esantis oro kiekis.

Atlikta nemažai mokslinių tyrimų vertinant padarytą gaisro žalą konstrukcijoms iš cementinio betono. Tačiau, mažai dèmesio skiriama betono sudètinių dalių įtakai - cemento, užpildų bei cheminių i̇maišų, turinčių skirtingą įtaką betono savybėms. Betonas yra daugiakomponentis kompozitas, kurio struktūra yra sudètinga, o veikiant gaisrui betone vyksta daug procesų - nuo šilumos perdavimo, vandens garų migracijos iki ịvairių cheminių junginių skilimų. Šiame darbe atliktuose tyrimuose sprendžiamas pagrindinis uždavinys - ištirti cemento tipo, užpildų bei oro kiekio ịtaką cementinio betono atsparumui ugniai.

Disertaciją sudaro įvadas, trys skyriai, bendrosios išvados, naudotos literatūros ir autoriaus publikacijų disertacijos tema sąrašai. İvadiniame skyriuje aptariama tiriamoji problema, darbo aktualumas, aprašomas tyrimu objektas, formuluojamas darbo tikslas bei uždaviniai, darbo mokslinis naujumas, darbo rezultatų praktinè reikšmè, ginamieji teiginiai. Ivvado pabaigoje pristatomos disertacijos tema autoriaus paskelbtos publikacijos ir pranešimai konferencijose bei disertacijos struktūra. Pirmasis skyrius skirtas literatūros analizei betoninių bei gelžbetoninių konstrukcijų atsparumo ugniai klausimais. Skyriaus pabaigoje pateikiamos išvados ir formuluojami disertacijos uždaviniai. Antrajame skyriuje aprašytos tyrimams naudotos medžiagos ir atliktų tyrimų metodikos bei naudota įranga. Trečiajame skyriuje pateikti betono destrukcinių procesų tyrimai aukštose temperatūrose bei skirtingų cementų, įvairių užpildų ir oro kiekio betono mišinyje itakos betono atsparumui ugniai tyrimų rezultatai. Darbo pabaigoje suformuluotos bendrosios išvados.

Disertacijos tema paskelbti 3 moksliniai straipsniai ir perskaityti 5 pranešimai Lietuvos bei kitų šalių konferencijose. 


\section{Abstract}

Fire resistance of concrete is an important factor for buildings structures fire safety - essential characteristics of buildings, it is defined on the basis of the following criteria: $\mathrm{R}$ - ability to withstand structural loads, E - conform to (satisfy) integrity and I - insulation characteristics for the fire resistance period given. During reinforced concrete structures design several criteria are taken into account, excluding, however, performance characteristics and components of concrete (e.g. composition of cement, characteristics of aggregates and air content in concrete mixture) which is used to make the structure.

There are a number of scientific researches carried out with various types of cement concrete to assess the damage caused to cement concrete structures. However, insufficient attention is being paid to the impact of the components of concrete - cements, aggregates and chemical admixtures having different influence on concrete properties. Concrete is a multi-component composite with a complex structure, which if exposed to a fire has numerous processes taking place in it - from heat transfer, water vapor migration to various disintegrations of chemical compounds. The main objective of the researches carried out in the dissertation was to analyze the impact of the types of cement, aggregates and air content in concrete mixture on the fire resistance of cement concrete.

The dissertation consists of an introduction, three chapters, general conclusions, the list of references and author's publications on the topic of the dissertation. The introduction reveals the investigated problem, the importance of the dissertation, describes the object of the research, describes the purpose and the tasks of the dissertation, the scientific novelty, the practical significance of results examined in the paper and defended statements. The introduction ends in presenting the author's publications on the subject of the dissertation and presentations in conferences and defining the structure of the dissertation. The first chapter revises the literature used, defines the issues of the impact of high temperatures on the fire resistance of concrete and reinforced concrete structures. At the end of the chapter, conclusions are given and the tasks for the dissertation are formulated. The second chapter presents the materials used for the research, as well as the methodology and the equipment used. The third chapter presents peculiarities of destruction processes of concrete in high temperature and the impact of different types of cements, aggregates and air content on the fire resistance of concrete. At the end of the thesis, general conclusions are given.

Three articles on the subject of the dissertation were published and five re-

ports on the subject of the dissertation have been presented in Lithuanian and foreign conferences. 


\section{Žymèjimai}

\section{Simboliai}

a - atstumas nuo temperatūros veikiamo betono paviršiaus iki armatūros sunkio centro, $\mathrm{mm}$;

$\mathrm{a}_{500}$ - atstumas nuo temperatūros veikiamo betono paviršiaus iki sluoksnio, kuriame pasiekiama $500{ }^{\circ} \mathrm{C}$ temperatūra, mm;

E 30 arba E 180 - elementas, standartinio gaisro sąlygomis atitinkantis vientisumo E kriterijų $30 \mathrm{~min}$ arba $180 \mathrm{~min}$;

I 30 arba I 180 - elementas, standartinio gaisro sąlygomis atitinkantis šilumos izoliavimo I kriterijų $30 \mathrm{~min}$ arba $180 \mathrm{~min}$;

$\mathrm{R}$ - koreliacijos koeficientas;

$\mathrm{R}^{2}$ - determinacijos koeficientas;

R 30 arba R 180 - elementas, standartinio gaisro sąlygomis atitinkantis laikomosios galios R kriterijų 30 min arba 180 min;

$\mathrm{S}_{\mathrm{e}}$ - vidutinis standartinis nuokrypis;

$\tau$ - trukmè, min;

$\mathrm{T}$ - temperatūra, ${ }^{\circ} \mathrm{C}$. 


\section{Santrumpos}

DTA - diferencinè terminè analizé;

DTG - diferencinè termogravimetrija;

IR - infraraudonujų spindulių spektroskopinè analizè;

$\mathrm{TG}$ - termogravimetrinè analizè.

\section{Terminai ir apibrèžimai}

Apsauginis sluoksnis - bet kokia medžiaga ar medžiagų derinys, kuriuo padengiamas konstrukcijos elementas, siekiant padidinti jo atsparumą ugniai.

Atsparumas ugniai - konstrukcijos charakteristika gaisro metu atlaikyti nustatytą trukmę apkrovas (R kriterijus), vientisumą (E kriterijus), izoliavimo charakteristikas (I kriterijus).

Kritinė armatūros temperatūra - armatūros temperatūra, kurioje gaisro sąlygomis, esant tam tikram plieno ịtempių lygiui, numatoma elemento irtis.

Mineralinis priedas - tai smulkiai sumaltos gamtinès uolienos arba pramonès atliekos, kurių dedama maišant mišinius.

Orą įtraukianti įmaiša - tai medžiaga, didinanti oro kiekị mišiniuose ir sudaranti smulkių sferinių oro porų tinklą. Oro ịtraukimas ị mišinị vyksta mišinio maišymo metu.

Oro kiekis betono mišinyje - tai oro kiekis, išreikštas procentais ir atsirandantis mišinio sferinèse porose, susidarančiose maišymo metu.

Standartinis gaisras - gaisras, kuris vystosi pagal standarte LST EN 1363-1:2012 aprašytą etaloninę temperatūros ir laiko kreivę.

Sumažintasis skerspjūvis - elemento skerspjūvis, imamas skaičiuojant konstrukcijų elgseną ugnyje ir taikant sumažintojo skerspjūvio metodą. Jis gaunamas iš liekamojo skerspjūvio atemus tas skerspjūvio dalis, kurios laikomos netekusiomis stiprumo ir standumo. 


\section{Turinys}

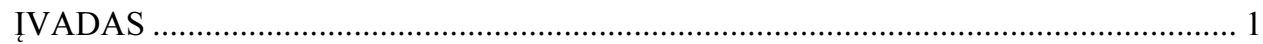

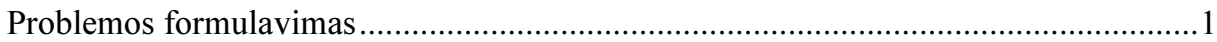

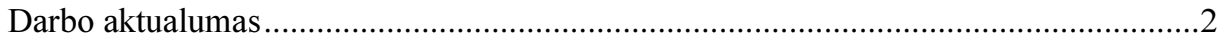

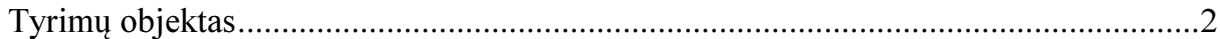

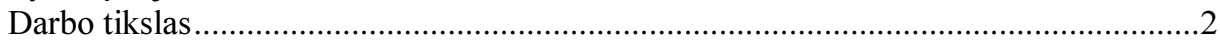

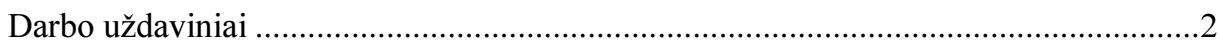

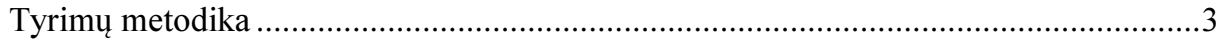

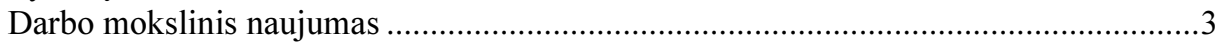

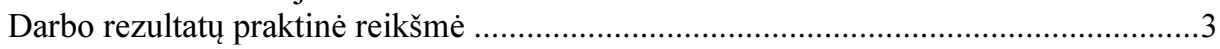

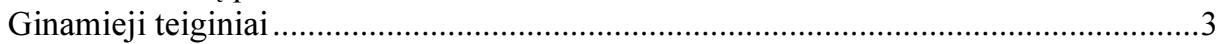

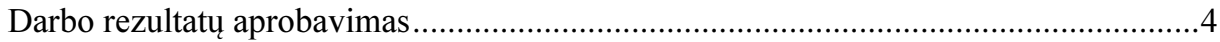

Disertacijos struktūra.........................................................................................

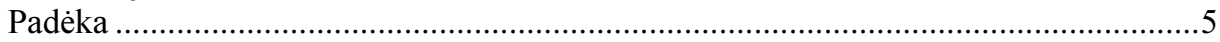

1. TEMPERATŪROS ITAKOS BETONO KOMPONENTAMS, STRUKTŪRAI IR SAVYBĖMS MOKSLINIŲ TYRIMŲ ANALIZE் .................................................... 7

1.1. Cementinio akmens ir betono struktūra .................................................................

1.1.1. Portlandcemenčio hidratacijos produktai ir struktūra ................................... 9

1.1.2. Cementinio akmens poringumas ........................................................... 12

1.1.3. Betono gamybai naudojami užpildai ..................................................... 13

1.1.4. Priedų ir cheminių įmaišų įtaka betono struktūrai ........................................ 14 


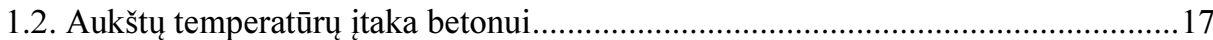

1.2.1. Dehidratacijos procesai cementiniame akmenyje ................................... 17

1.2.2. Betono užpilduose vykstantys fizikiniai ir cheminiai procesai aukštose

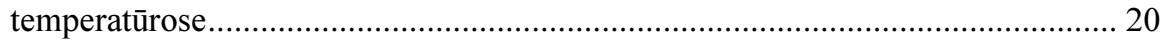

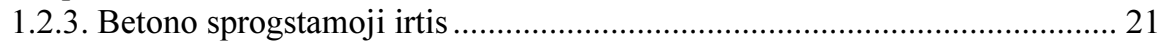

1.3. Gelžbetonio atsparumo ugniai vertinimo charakteristikos ....................................22

1.4. Apsauginio betono sluoksnio storio iki armatūros vertinimas................................24

1.5. Pirmojo skyriaus išvados ir disertacijos uždavinių formulavimas.........................26

2. TYRIMAMS NAUDOTOS MEDŽIAGOS IR ATSPARUMO UGNIAI

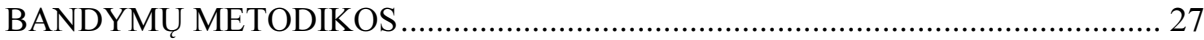

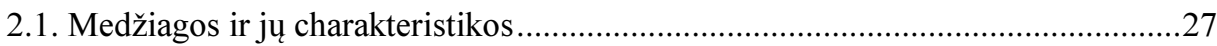

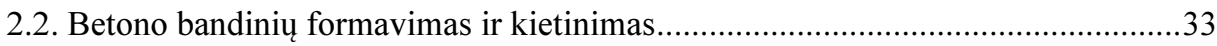

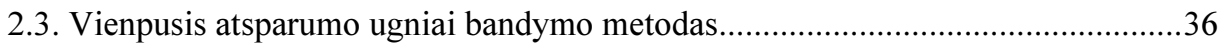

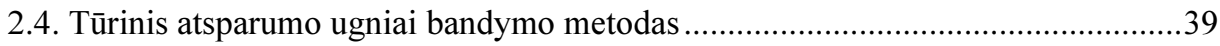

2.5. Cementinio akmens ir betono savybių vertinimas .................................................4

2.5.1. Cementinio akmens ir užpildų termogravimetrinè ir infraraudonūjų

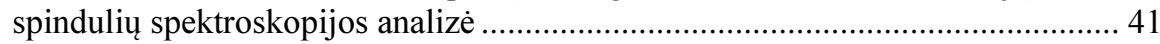

2.5.2. Betono savybių pokyčiai po kaitinimo …………...................................... 42

2.5.3. Betono dilatometrinè ir mikrostruktūros analizè........................................ 42

2.6. Tyrimų rezultatų statistinio apdorojimo metodika..................................................43

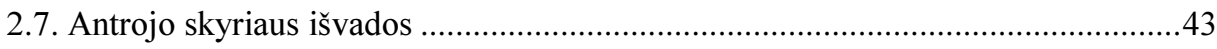

3. CEMENTO TIPO, UŽPILDU BEI ORO KIEKIO ITTAKA BETONO IRIMO PROCESAMS VEIKIANT AUKŠTAI TEMPERATÜRAI ………............................. 45

3.1. Mineraliniu priedų įtaka betono atsparumui ugniai ..............................................46

3.1.1. Temperatūros pasiskirstymas betone su skirtingais cementais esant vienpusiam temperatūros poveikiui ..................................................................... 46

3.1.2. Temperatūros pasiskirstymas betone su skirtingais cementais esant tūriniam temperatūros poveikiui ........................................................................ 50

3.1.3. Mineralinio priedo itaka cementinio akmens destrukciniams procesams ... 52

3.1.4. Mineralinio priedo įtaka betono savybiu pokyčiams veikiant aukštai

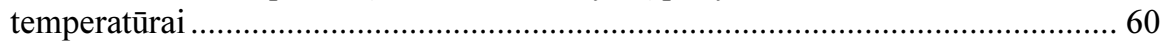

3.2. Užpildų ịtaka betono atsparumui ugniai ...........................................................63

3.2.1. Temperatūros pasiskirstymas betone su skirtingais užpildais esant vienpusiam temperatūros poveikiui

3.2.2. Temperatūros pasiskirstymas betone su skirtingais užpildais esant

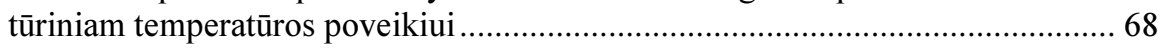

3.2.3. Destrukciniai procesai užpilduose veikiant aukštai temperatūrai ................ 70

3.2.4. Užpildo mineralinès sudeties įtaka betono savybių pokyčiams veikiant aukštai temperatūrai .............................................................................................. 72

3.3. Itraukto oro kiekio itaka betono atsparumui ugniai ...............................................76

3.3.1. Temperatūros pasiskirstymas betone su skirtingu oro kiekiu esant vienpusiam temperatūros poveikiui 
3.3.2. Oro kiekio ịtaka betono savybių pokyčiams veikiant aukštai temperatūrai

3.3.3. Betono su skirtingu oro kiekiu mikrostruktūros pokyčiai veikiant

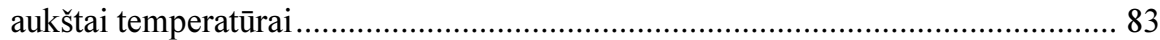

3.3.4. Temperatūrinio režimo betone gaisro metu prognozavimas ........................ 87

3.4. Trečiojo skyriaus išvados ............................................................................... 90

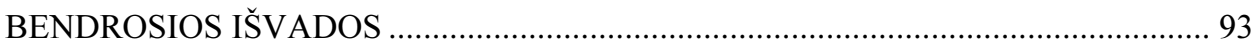

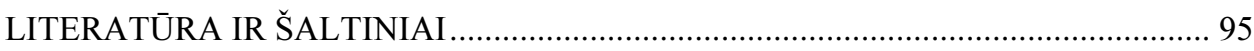

AUTORIAUS MOKSLINIŲ PUBLIKACIJŲ DISERTACIJOS TEMA SĄRAŠAS ... 103

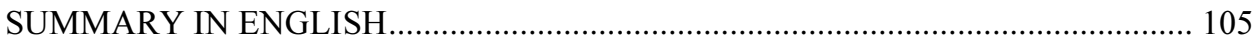

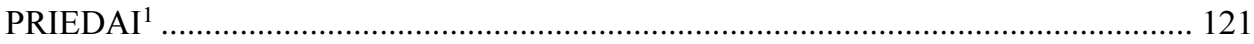

A priedas. Disertacijos autoriaus sąžiningumo deklaracija ................................... 122

B priedas. Bendraautorių sutikimai teikti publikacijose skelbtą medžiagą mokslo

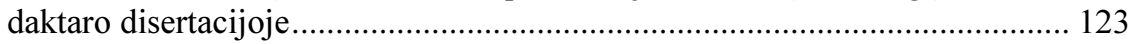

C priedas. Autoriaus mokslinių publikacijų disertacijos tema kopijos..................... 125

${ }^{1}$ Priedai pateikiami pridètoje kompaktinèje plokštelèje 



\section{Content}

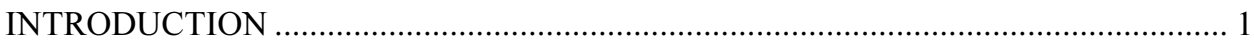

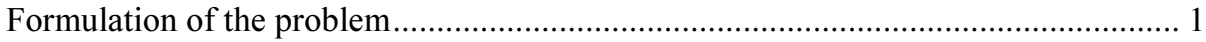

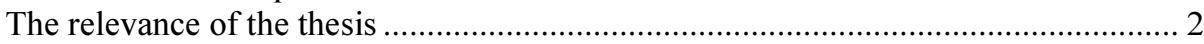

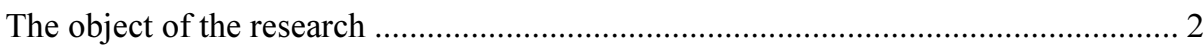

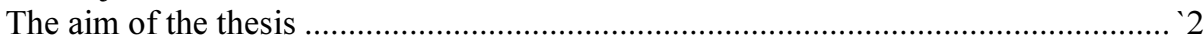

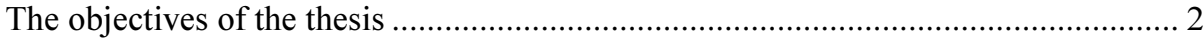

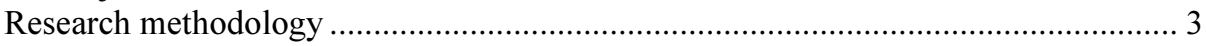

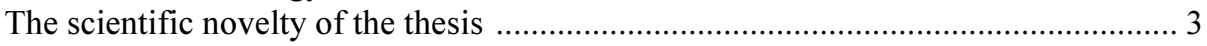

The practical value of the research finding ………............................................... 3

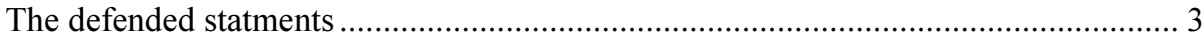

The approval of the research findings ................................................................ 4

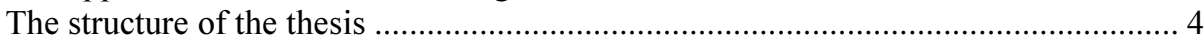

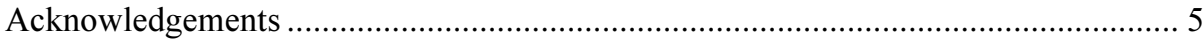

1. SCIENTIFIC RESEARCH ANALYSIS OF TEMPERATURE INFLUENCE ON CONCRETE COMPONENTS, STRUCTURE AND PROPERTIES ........................... 7

1.1. Structure of the hardened cement paste and concrete........................................... 7

1.1.1. Potland cement hydration products and structure ……………………....... 9

1.1.2. Porosity of hardened cement paste ………….......................................... 12

1.1.3. Aggregates for concrete production ......................................................... 13

1.1.4. Influence of aditives and chemical admixtures on concrete structure......... 14

1.2. High-temperature influence on concrete ........................................................... 17

1.2.1. Dehydration processes in hardened cement paste ...................................... 17 
1.2.2. Physico and chemical processes in concrete aggregates at high

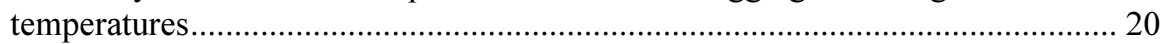

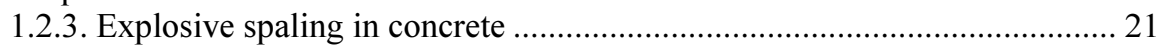

1.3. Evaluation parameters of reinforced concrete fire resistance ............................. 22

1.4. Evaluation of protective layer of concrete to reinforcement .............................. 24

1.5. Conliusions of first chapter and formulation of thesis objectives........................ 26

2. MATERIALS USED FOR TESTING AND FIRE RESISTANCE TESTING

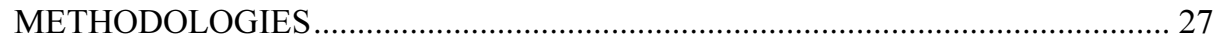

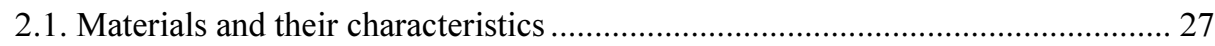

2.2. Preparation and hardering of concrete samples ............................................... 33

2.3. One-sided fire resistance evaluation method ..................................................... 36

2.4. Volumetric fire resistance evaluation method ..................................................... 39

2.5. Evaluation of hardened cement paste and concrete properties ........................... 41

2.5.1. Thermogravimetric and infrared spectroscopy analysis of hardened

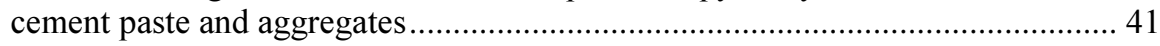

2.5.2. Changes in concrete properties after heating ............................................ 42

2.5.3. Dilatometrical and microstructure analysis of concrete.............................. 42

2.6. Method of statistical analysis of testing results .................................................... 43

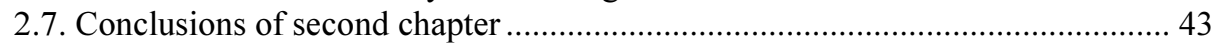

3. TYPE OF CEMENT, AGGREGATES AND THE AMOUNT OF AIR INFLUENCE ON CONCRETE EXPOSURED TO ELEVATED HIGH TEMPERATURES

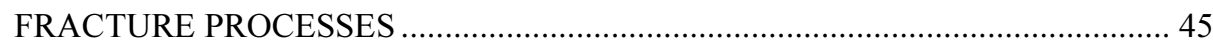

3.1. Infuence of mineral additives on concrete fire resistance ................................... 46

3.1.1. Temperature distribution in concrete with different cements during

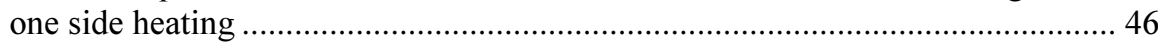

3.1.2. Temperature distribution in concrete with different cements during

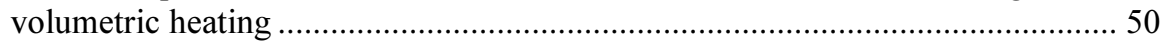

3.1.3. Infuence of mineral aditives on hardened cement paste destruction

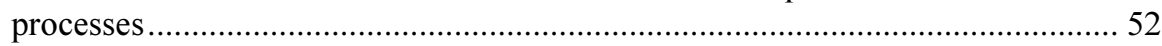

3.1.4. Infuence of mineral aditives on concrete changes in properties exposed

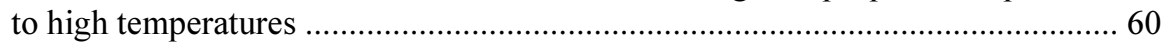

3.2. Influence of aggregates on concrete fire resistance ............................................ 63

3.2.1. Temperature distribution in concrete with different aggregates during

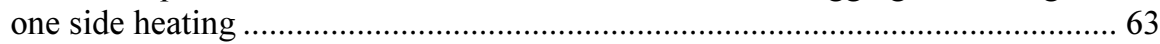

3.2.2. Temperature distribution in concrete with different aggregates during

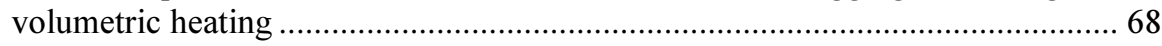

3.2.3. Destructive processes in aggregates exposured to high temperature .......... 70

3.2.4. Inluence of mineral composition of aggregates changes in properties in concrete exposured to high temperature …………….......................................... 72

3.3. Infuence of entrained air content on concreate fire resistance............................. 76

3.3.1. Temperature distribution in concrete with different amount of air during one side heating 
3.3.2. Infuence of air content on concreate changes in properties exposured to high temperature

3.3.3. Microstructure changes in concrete with different air content exposured to high temperature.

3.3.4. Prediction of temperature distribution in concrete during fire ................... 87

3.4. Conclusions of third chapter............................................................................. 90

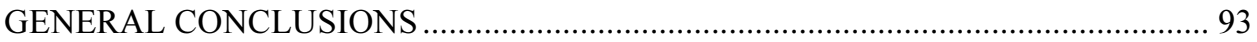

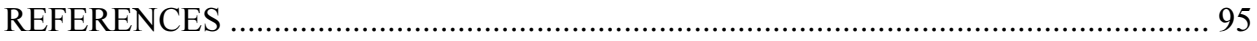

LIST OF SCIENTIFIC PUBLICATIONS BY THE AUTHOR ON THE TOPIC OF

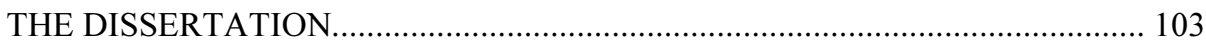

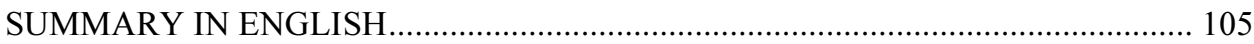

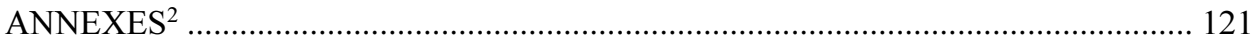

Annex A. Author declaration of academic integrity ............................................. 122

Annex B. The co-authors' agreements for providing the materials of the joint publications in the thesis.............................................. 123

Annex C. Copies of the scientific publications by the author on the topic of the

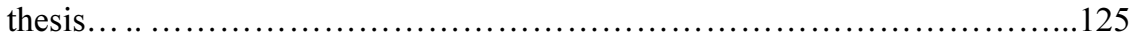

${ }^{2}$ The annexes are provided in the enclosed compact disc. 



\section{Ivadas}

\section{Problemos formulavimas}

Gelžbetoninių konstrukcijų gamybai gali būti naudojami ịvairūs cementiniai betonai, kurie gali skirtis cemento tipu, užpildais ir cheminèmis įmaišomis. Tai daro įtaką betono mikrostruktūrai ir vykstantiems procesams aukštose temperatūrose. Betono struktūros ypatumai yra svarbūs vertinant betono atsparumą ugniai. Šiuo metu projektuojant gelžbetoninių konstrukcijų atsparumą ugniai nepakankamai atsižvelgiama ị konstrukcijų gamybai naudojamo betono charakteristikas, gamybai naudojamas medžiagas bei sudètị ir ypač i ịtraukto oro kieki betone.

Gelžbetoninių konstrukcijų atsparumas ugniai nustatomas pagal betono apsauginio sluoksnio storị iki armatūros, tačiau gelžbetoninèse konstrukcijose, kurioms keliami dideli atsparumo ugniai reikalavimai (kriterijus R 180), siekiant išvengti papildomų apsauginių sluoksnių reikalinga tiksliai įvertinti temperatūrinių laukų pasiskirstymą betono skerspjūvyje ir tinkamai parinkti tokio betono gamybai naudojamas medžiagas bei jo sudèti.

Šiame darbe nagrinèjami skirtingo tipo cementų, įvairių užpildų bei oro kiekio įtaka betono atsparumui ugniai. 


\section{Darbo aktualumas}

Vienas iš esminių statybinėms medžiagoms keliamų reikalavimų - atsparumas ugniai. Norint pagaminti efektyvias didelio atsparumo ugniai gelžbetonines konstrukcijas, būtina vertinti paties betono techninius pokyčius aukštose temperatūrose, tinkamai parinkti tokio betono žaliavas, komponentų kiekius jame, sukurti aukštoms temperatūroms atsparią betono mikrostruktūrą (optimizuoti betono poringumą). Darbo rezultatai taikytini atsparių gaisrui gelžbetoninių konstrukciju projektavimui ir padidinto atsparumo ugniai cementinio betono gamybai.

\section{Tyrimų objektas}

Darbe tiriamas betono su skirtingais cementais, turinčiais skirtingus mineralinius priedus (aukštakrosnių šlako, klinties), skirtingais stambiaisiais užpildais (žvirgždo, granito skaldos, dolomito skaldos, keramzito) bei skirtingu itraukto oro kiekiu atsparumas ugniai.

\section{Darbo tikslas}

Ištirti cemente esančių mineralinių priedų (aukštakrosnių šlako, klinties), skirtingų betono užpildų ir įtraukto oro kiekio betono mišinyje įtaką betono atsparumui ugniai.

\section{Darbo uždaviniai}

Darbo tikslui pasiekti sprendžiami šie uždaviniai:

1. Nustatyti aukštos temperatūros pagal standartinę gaisro kreivę paveiktų betonų su skirtingais cementais, užpildais ir įtraukto oro kiekiu temperatūrų pasiskirstymą betono skerspjūvyje ir aprašyti tai matematiškai.

2. Ištirti irimo procesus dèl temperatūrinio poveikio betone su skirtingais cementais bei užpildais.

3. Nustatyti betono su skirtingu įtraukto oro kiekiu mikrostruktūros bei fizikinių mechaninių savybių pokyčius veikiant aukštai temperatūrai. 
4. Nustatyti naudotinas betono gamybai žaliavas bei reikiamą oro kiekị betono mišinyje projektuojant padidinto atsparumo ugniai betonines konstrukcijas.

\section{Tyrimų metodika}

Betono mišinių technologinių charakteristikų vertinimui naudoti standartiniai slankumo, tankio, oro kiekio nustatymo metodai. Sukietejusiam betonui tirti naudoti gniuždymo stiprio, ultragarso impulso sklidimo greičio bandymų metodai. Betono temperatūrinių laukų išsidèstymui tirti naudoti vienpusio ir tūrinio atsparumo ugniai nustatymo metodai pagal standartinę gaisro kreivę. Cementinio akmens irimo procesams, skirtingiems užpildams ir betonui tirti buvo naudojami masès nuostolių, termogravimetrijos, infraraudonujų spindulių spektroskopijos ir dilatometijos metodai. Mikrostruktūros pokyčiai betone buvo tiriami naudojant skenuojančią elektroninę mikroskopiją.

\section{Darbo mokslinis naujumas}

Atlikus tyrimus, gauti šie medžiagų inžinerijos mokslui nauji rezultatai:

1. Gauti temperatūros pasiskirstymo dèsningumai betonuose su skirtingais cementais, užpildais bei skirtingu įtraukto oro kiekiu aplinkos temperatūrai keičiantis pagal standartinę gaisro kreivę.

2. Nustatyta ịtraukto oro kiekio betono mišinyje itaka betono atsparumui ugniai ir efektyvus jo kiekis padidinto atsparumo ugniai betonuose.

\section{Darbo rezultatų praktinè reikšmè}

Pateikti praktiniai siūlymai dèl cemento tipo, užpildų ir cheminių įmaišų parinkimo projektuojant padidinto atsparumo ugniai betono sudètis.

Gauti rezultatai naudotini apsauginio betono sluoksnio iki armatūros projektavimui norimo atsparumo ugniai gelžbetoninèse konstrukcijose pagal autoriaus siūlomas matematines lygtis.

\section{Ginamieji teiginiai}

1. Cemente esantis mineralinis priedas (aukštakrosnių šlakas), darantis ịtaką adsorbuoto vandens kiekiui cementiniame akmenyje ir užpildo mineraluose 
vykstantys kristalinės gardelès pokyčiai sukeliantys deformacinius procesus kaitinamame betone, daro neigiamą itaką betono atsparumui ugniai.

2. Oro kiekio betono mišinyje padidinimas iki $5 \%$ kompensuoja temperatūrines deformacijas betone ir vandens garų migracijos sukeltą slègi veikiant aukštai temperatūrai ir naudotinas betono atsparumo ugniai padidinimui.

\section{Darbo rezultatụ aprobavimas}

Disertacijos tema paskelbtos trys publikacijos užsienio mokslo žurnaluose, iš kurių dvi referuojamos duomenų bazèje Scopus.

Disertacijoje atliktų tyrimų rezultatai buvo paskelbti penkiuose pranešimuose mokslinèse konferencijose Lietuvoje ir užsienyje:

- Jocius V. 2011. Cementinio betono irimo mechanizmas veikiant aukštai temperatūrai, 14-oji Lietuvos jaunujų mokslininkų konferencija „Mokslas - Lietuvos ateitis“.

- Jocius V., Skripkiūnas G., Lipinskas D. 2012. Cemento tipo įtaka betono atsparumui ugniai. Respublikinė konferencija „Medžiagų inžinerija 2012 “.

- Jocius V., Skripkiūnas G., Lipinskas D. 2013. The Infuance of Cement Type and Different Types of Fillers on Fire Resistance of Concrete. Rygos technikos universiteto 54-oji tarptautinè mokslinè konferencija.

- Jocius V., Skripkiūnas G., Lipinskas D. 2013. Cemento tipo ir užpildų itaka betono atsparumui ugniai. Respublikinè konferencija „Medžiagų inžinerija 2013“.

- Jocius V., Skripkiūnas G., Lipinskas D. 2014. Agregates Infuance on the Fire Resistance of Concrete. Rygos technikos universiteto 55-oji tarptautinè mokslinè konferencija.

\section{Disertacijos struktūra}

Disertaciją sudaro įvadas, trys skyriai, bendrosios išvados, naudotos literatūros ir disertacijos autoriaus publikacijų sąrašai.

Darbo apimtis yra 103 puslapiai, neiskaitant santraukos anglu kalba ir priedų, tekste panaudotos 5 numeruotos formulès, 60 paveikslų ir 20 lentelių. Rašant disertaciją remtasi 108 literatūros šaltiniais. 


\section{Padéka}

Nuoširdžiai dèkoju Varšuvos technikos universiteto Plocko filialo Chemijos instituto darbuotojams, vadovaujamiems prof. habil. dr. Barbaros Pacevskos už vertingus patarimus ir atliktus termogravimerijos bei infraraudonujų spindulių spektroskopinius tyrimus mokslinès stažuotès metu. 



\section{1}

\section{Temperatūros ịtakos betono komponentams, struktūrai ir savybèms mokslinių tyrimų analizè}

Skyriuje analizuojami literatūros šaltiniai apie temperatūros ittaką betono komponentams, struktūrai ir savybèms. Nagrinèjama cementinio akmens struktūra, poringumas ir vykstantys procesai aukštose temperatūrose, betono gamybai naudojamų skirtingų užpildų savybès ir vykstantys fizikiniai - cheminiai procesai aukštose temperatūrose, bei gelžbetoninių konstrukcijų vertinimas atsparumo ugniai požiūriu.

Skyriaus tematika paskelbti trys straipsniai (Jocius et al. 2013; Jocius et al. 2014; Jocius, Skripkiūnas 2016).

\subsection{Cementinio akmens ir betono struktūra}

Cementinis akmuo yra poringas kūnas, kuriame didžiają dalị kietosios fazès sudaro koloidinio dispersiškumo mikrokristalai, kurie suriša gana didelị kiekị vandens (Eisinas et al. 2009).

Betonas - kompozitas, susidedantis iš rišamosios medžiagos, užpildų, vandens bei priedų. Sumaišius cementą su vandeniu vyksta daugybe cheminių 
reakcijų, kurios vadinamos cemento hidratacijos procesu. Kaitinant betoną vyksta cemento mineralų ir naujadarų dehidratacijos procesai, kurie ardo betono mikrostruktūrą (Skripkiūnas 2007).

Betonas yra konglomeratinès struktūros medžiaga sudaryta iš cementinès matricos ir užpildų. Konglomeratinè struktūra betone kartojasi keliais lygmenimis, tai yra betoną sudaro stambieji užpildai, pasiskirstę skiedininès dalies matricoje. Skiedininę dali sudaro smulkieji užpildai, pasiskirstę cementinèje tešloje arba sukietejusiame cementiniame akmenyje, o cementini akmeni sudaro cemento hidratacijos produktai (Skripkiūnas 2007).

Rišamosioms medžiagoms priskiriamas portlandcementis ir jo atmainos šlakiniai ir pucolaniniai cementai bei aliuminatinis cementas, plètrusis cementas ir kiti. Priklausomai nuo cemento klinkerio mineralinès sudeties, priedų ir gaunamų cemento savybių gaminami ịvairūs cementai. Išskiriami penki ịprastinio cemento tipai: CEM I - portlandcementis, CEM II - sudetinis portlandcementis, CEM III - šlakinis cementas, CEM IV - pucolaninis cementas ir CEM V - sudètinis cementas. CEM I portlandcementi sudaro 95-100\% klinkeris, CEM II/A-S šlakini portlandcementị sudaro 80-94 \% klinkeris ir 6-20\% aukštakrosnių šlakas, CEM II /A-LL klinties portlandcementị sudaro 80-94 \% klinkeris ir 6-20\% klintys, CEM III/B šlakini cementą sudaro 20-34 \% klinkeris ir 66-80 \% aukštakrosnių šlakas (LST EN 197-1:2011).

Kita betono sudedamoji dalis yra užpildai. Smulkiuoju užpildu vadinamas toks užpildas, kurio stambiausios dalelès yra ne didesnès kaip $4 \mathrm{~mm}$, o stambiuoju užpildu vadinamas toks užpildas, kurio stambiausios dalelès ne mažesnès kaip $4 \mathrm{~mm}$ ir smulkiausios dalelès ne mažesnès kaip $2 \mathrm{~mm}$. Pagal kilmę užpildai skirstomi ị: gamtinius, dirbtinius, iš pramonès atliekų bei iš antriniu žaliavų. Pagal stambiojo užpildo kieki konglomeratai skirstomi i ,plaukiojančios" struktūros, kai stambusis užpildas atskirtas storais skiedininès dalies sluoksniais ir vienas su kitu nekontaktuoja, ị kontaktinès struktūros, kai skiedinine dalis užpildo visas tuštumas tarp stambiojo užpildo, sudarydama nedidelio storio apvalkalus aplink stambiuosius užpildus ir stambiaporès struktūros, kai skiedininès dalies tūris mažesnis už tuštumų tūrị tarp stambiojo užpildo dalelių ir skiedinys tik padengia stambuji užpildą plonu sluoksniu, o tuštumos tarp stambiojo užpildo lieka neužpildytos (Deltuva et al. 1982).

Vanduo arba vandeniniai tirpalai sudaro betono mišiniuose skystają fazę. Dèl fizikinių ir cheminių procesų mišiniai, užmaišyti vandeniu, ịgauna rišlumą ir tam tikras reologines savybes. Vanduo atlieka svarbų vaidmenį hidratacijos procesuose. Statybinių mišinių ruošimui vanduo turi atitikti tam tikrus reikalavimus, t. y. negali būti priemaišų, kurios sukelia sukietejusio betono koroziją, organinių priemaišų, kurios lètina rišiklių hidratacijos procesus, ribojamas chloridų, sulfatų, šarmų, fosfatų, nitratų kiekis, kuris sukelia betono sulfatinę arba šarminę betono korozijas (Deltuva et al. 1982). 
Kietejjimo procesams reguliuoti arba technologinėms savybėms išgauti dedami priedai. Jie skirstomi ị mineralinius ir chemines ịmaišas. Cheminès ịmaišos - tai cheminès medžiagos, kurių nedideli kiekiai ị mišinius įmaišomi ruošimo metu. Pagal veikimo pobūdị cheminès įmaišos skirstomos ị keletą grupių: reologines savybes reguliuojančios, rišimosi ir kietejjimo intensyvumą reguliuojančios, specialiosios, daugiafunkcinius priedus. Mineraliniai priedai - tai smulkiai sumaltos gamtinès uolienos arba pramonès atliekos, kurių dedama maišant mišinius, jie skirstomi i aktyviuosius priedus ir mikroužpildus (Žurauskienè et al. 2012). Išvardintos betono sudedamosios dalys yra svarbios projektuojant atitinkamas savybes turintị betoną.

\subsubsection{Portlandcemenčio hidratacijos produktai ir struktūra}

Portlandcemenčio kietejjimas vyksta vandens terpejje, prisotintoje kalcio hidroksido $\mathrm{Ca}(\mathrm{OH})_{2}$. Cemento mineralai su vandeniu sudaro naujus hidratuotus junginius. Svarbiausi produktai, susidarantys cemento hidratacijos metu yra trys (Balandis et al. 2004; Некрасов 1957):

1. Kalcio hidrosilikatai (C-S-H).

2. Kalcio hidroksidas $(\mathrm{CH})$.

3. Kalcio hidrosulfoaliuminatas - trisulfate $(\mathrm{AFt})$ arba viensulfate $(\mathrm{AFm})$ forma.

Kalcio hidrosilikatų sudètis priklauso nuo įvairių veiksnių, ypač nuo temperatūros ir $\mathrm{Ca}(\mathrm{OH})_{2}$ koncentracijos tirpale. Dikalcio silikatui reaguojant su vandeniu susidaro kalcio hidrosilikatai, kaip ir trikalcio silikato hidrolizės metu, tačiau neišsiskiria $\mathrm{Ca}(\mathrm{OH})_{2}$. Hidratuojantis trikalcio aliuminatui, formuojasi skirtingi kalcio hidroaliuminatai, iš kurių stabilus yra $3 \mathrm{CaO} \cdot \mathrm{Al}_{2} \mathrm{O}_{3} \cdot 6 \mathrm{H}_{2} \mathrm{O}$. Reaguodamas su vandeniu, tetrakalcio aliumoferitas hidrolizuojasi ir susidaro kalcio hidroaliuminatas $3 \mathrm{CaO} \cdot \mathrm{Al}_{2} \mathrm{O}_{3} \cdot 6 \mathrm{H}_{2} \mathrm{O}$ ir kalcio hidroferitas $\mathrm{CaO} \cdot \mathrm{F}_{2} \mathrm{O}_{3}$ - $\mathrm{nH}_{2} \mathrm{O}$ (Бутт 1980). Kalcio hidroferitas toliau jungiasi su $\mathrm{Ca}(\mathrm{OH})_{2}$ ir virsta didesnio bazingumo junginiu. Gipsas reaguoja su trikalcio aliuminatu ir suformuoja trisulfati kalcio hidrosulfoaliuminatą $3 \mathrm{CaO} \cdot \mathrm{Al}_{2} \mathrm{O}_{3} \cdot 3 \mathrm{CaSO}_{4} \cdot 31 \mathrm{H}_{2} \mathrm{O}$. Cemento mineralų hidratacijos greitis yra skirtingas. Greičiausiai hidratuoja trikalcio aliunimatas, po to tetrakalcio aliumoferitas, vèliau trikalcio silikatas (alitas), ir lèčiausiai hidratuoja dikalcio silikatas (belitas) (Некрасов, K 1957).

Mokslininkai atliko portlandcemenčio tešlų su ịvairiais katalizinio krekingo katalizatoriais ir lakiujų pelenų mišinių pakaitalais termogravimetrines analizes. Katalizatoriaus kiekiai tyrime varijavo nuo $0-15 \%$, lakiuju pelenu - nuo 0-30 \%. Tešlos buvo išlaikomos nuo 3 iki 365 dienų. Termogravimetrinè analizè parodè, kad padidinus katalizatoriaus procentini kieki sistemoje, kalcio aluminato hidrato ir kalcio aliumosilicio hidrato taip pat padideja. Lakiuju pe- 
lenų proporcijos didinimas nemodifikuoja cemento tešlose gautų hidratų tipų (Velazquez et al. 2016).

Mokslininkai tyrinejo didelio stiprumo savarankiškai sutankinto betono, kuriame buvo $\mathrm{TiO}_{2}$ nanodalelių ir industrinių pelenų, stiprumo ir ilgaamžiškumo charakteristikas. Jie nustate, $\mathrm{kad}^{\mathrm{TiO}}{ }_{2}$ dalelèmis pakeitus cementą iki $4 \%$, buvo pagreitintas $\mathrm{C}-\mathrm{S}-\mathrm{H}$ gelio formavimasis dèl padidejusio kristalinio $\mathrm{Ca}(\mathrm{OH})_{2}$ kiekio ankstyvoje hidratacijos stadijoje ir taip pagerinta betono struktūra, stiprumas ir ilgaamžiškumas (Jalal et al. 2013).

Hidratacijos pradžioje kalcio hidrosilikatų kristalai būna smulkūs, jų storis sudaro kelias molekules, nepastovus vandens kiekis gardeleje suteikia hidrosilikatui koloido savybių ir leidžia sudaryti lygiagrečias sąaugas bei sulaikyti didelị kiekị vandens. Silikato geliuose yra ne tik chemiškai surišto, bet ir didelis kiekis adsorbuoto vandens. Cementui kontaktuojant su vandeniu, cemento mineralai tirpsta, ir $\mathrm{Ca}^{+}$jonai išsiskiria tol, kol tirpalas pasiekia pusiausvyrą. Vèliau nusodinami jonai, ir susidaro kristalų hidratai, cementas ima kietèti (Teilor 1996).

Mokslininkai išskiria keturis portlandcemenčio formavimosi etapus (Teilor 1996; Gawin et al. 2006; Hertz 2003):

1. Cemento dalelès, patekusios i vandeni, pradeda tirpti.

2. Stambių cemento dalelių paviršiuje susidaro hidratacijos produktų sluoksnis. Smulkiausios dalelès pavirsta hidratacijos produktų branduoliais. Cemento dalelès, pasidengusios hidratais, plečiasi, nes hidratų tūris yra didesnis už cemento miltelių tūrị.

3. Dèl plètimosi mažesnieji branduoliai kontaktuoja su didžiujjų dalelių paviršiumi, taip įsiterpia ir sudaro klasterio struktūrą.

4. Toliau plečiantis klasteriai kontaktuoja išsiplètusiose vietose ir sulimpa tarp savęs, sudarydami tiltelių struktūrą.

Hidratuojant cementui, vandens ir cemento tešloje išsiskiria šiluma, kuri ivairiais hidratacijos etapais yra skirtinga, tai pat skiriasi ir skirtingų markių cementų išskiriama hidratacijos šiluma.

Portlandcemenčio kietejjimo procesas trunka ilgai. Kietinant aukštesnejje temperatūroje kompozito stiprumas didejja kelis kartus greičiau ir gali pasiekti reikiamą stiprumą po $4-5$ parų kietejjimo. Prie $100-110^{\circ} \mathrm{C}$ temperatūros vyksta šutinimas, kuris žymiai paspartina hidratacijos procesus ir padidina cementinio akmens stiprumą. Stiprumas padideja iki 150-180 \% (Hung et al. 2001).

Portlandcemenčiui hidratuojant susidaro cementinis akmuo iš tokių mineralų: kalcio hidroksido, dikalcio hidrosilikato, kalcio hidrosulfoaliuminato, kalcio hidroaliuminato, kalcio hidroaliumoferito, nehidratuotų cemento mineralų.

Šie mineralai sudaro tankią ir stiprią cemento akmens struktūrą, susidedančią iš kristalinès ir gelinès struktūros medžiagos. 1.1 paveiksle pateiktas 
cemento akmens struktūros formavimasis hidratacijos metu (Khoshnazar et al. 2012).

a)<smiles></smiles>

b)

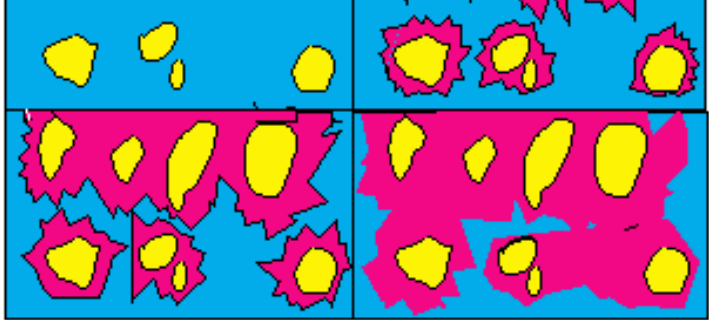

c)

d)

1.1 pav. Portlandcemenčio akmens struktūros formavimasis hidratacijos metu: a) plastiška būklè; b) rišimasis; c) pradinè struktūra; d) galutinè struktūra (Khoshnazar et al. 2012)

Fig 1.1. Portland cement stone structure formation during a hydratation: a) the plastic state; b) binding of cement paste; c) the primary structure; d) the final structure (Khoshnazar et al. 2012)

Cemento dalelèms reaguojant su vandeniu įvyksta reakcijos, kurių metu dali vandens suriša fiziškai, chemiškai, o nesureagavęs laisvas vanduo lieka didelèse kapiliarinèse porose. 1.2 paveiksle pateikta hidratuoto kalcio silikato vandens formu schema (Kumar et al. 2005).

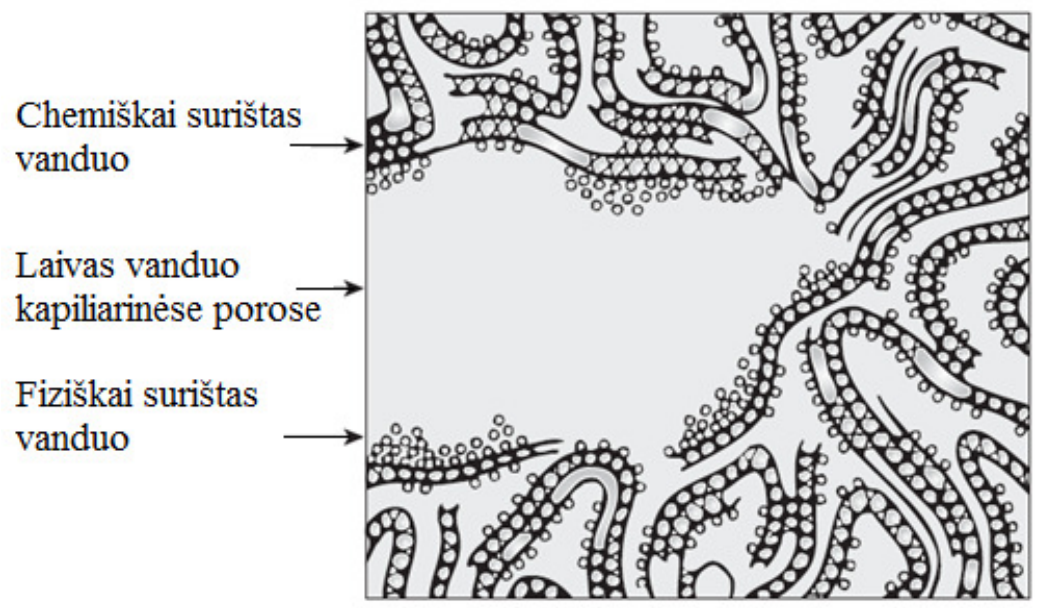

1.2 pav. Hidratuoto kalcio silikato vandens formų schema (Kumar et al., 2005)

Fig 1.2. Water forms scheme of fydrated calcium silicate (Kumar et al., 2005) 


\subsubsection{Cementinio akmens poringumas}

Cemento akmenyje yra labai ịvairaus dydžio porų, kurių dydis skiriasi tūkstančius kartų. Poros pagal formą, dydị ir prigimtị gali būti skirstomos ị tris grupes: kapiliarinès, gelio ir oro poros. Kapiliarinès poros sukietejusiame cemento akmenyje atsiranda išgaravus vandens pertekliui. Gaminant mišinị ir siekiant išgauti technologines savybes, vandens kiekis imamas didesnis, negu reikalingas cheminėms reakcijos. Vandens perteklius pasiskirsto gelio porose ir tarpuose tarp nesureagavusių cemento dalelių ir hidratacijos naujadarų. Iš jų išgaravus laisvam vandeniui lieka kapiliarinès poros, kurios susisiekia viena su kita siaurais kanalais. Kapiliarinių porų skersmuo yra $0,1-10 \mu \mathrm{m}$, jų kiekis cemento akmenyje daugiausia priklauso nuo laisvojo vandens kiekio ir hidratacijos laipsnio. Didejant V/C santykiui ir laisvojo vandens kiekiui cemento akmenyje, didèja kapiliarinių porų kiekis (Kalliopi 2006).

Cemento akmens kapiliarinis poringumas mažeja didejant cemento hidratacijos laipsniui, nes susidarančio naujadarų gelio tūris apie 2,2 karto didesnis už nehidratavusio cemento tūrị, ir cemento hidratacijos produktai užima dalị vandeniu užpildyto tūrio (Skripkiūnas 2007).

Gelio poros - tai tuštumos tobermoritiniame gelyje tarp šio gelio dispersinès fazès dalelių. Gelio poros daug smulkesnès už kapiliarines poras. Jų dydis yra 150-200 nm, jos apie 10 kartų didesnès už vandens molekulių dydị. Gelio porų kiekis cemento akmenyje didèjant hidratacijos laipsniui didèja, nes didëja paties gelio kiekis cemento akmenyje. Gelio poros labai smulkios, tačiau vandens pasišalinimas iš gelio porų sukelia cemento akmens susitraukimą ir valkšnumą. Oro poros cemento akmenyje yra stambiausios ir gali siekti iki kelių milimetrų dydžio. Jos yra uždaros, ju forma artima sferai. Oro poros susidaro maišant mišinius. Oro kiekiui padidinti dedami specialūs orą ịtraukiančios imaišos. Itraukto oro poros būna 50-200 $\mu \mathrm{m}$ dydžio ir yra daug stambesnès už kapiliarines poras. Jos mažina sukietejjusio mišinio stiprumą, tačiau didina atsparumą šalčiui ir vandens nelaidumą (Kalliopi 2006).

Oro poros mišinyje susidaro maišant mišini. Kietosios fazès paviršiuje esantis oras maišymo metu, pridèjus skystosios fazès i mišinį, uždaromas mišinyje. Šis oras vadinamas ị mišinị įtrauktu oru. Tankinimo metu šis oras susikaupia ir sudaro paprastai sferinès formos uždaras poras. Oro kiekiui mišinyje padidinti naudojami specialios cheminès įmaišos. Oro kiekis mišinyje priklauso nuo užpildo stambumo - kuo smulkesni užpildai mišinyje, tuo didesnis įtraukto oro kiekis. Stambiagrūdžiuose mišiniuose oro kiekis būna apie $1-1,5 \%$, o smulkiagrūdžiuose siekia 5-6\%. Oro kiekis mišinyje turi neigiamą įtaką sukietejjusio mišinio stiprumui, tačiau padidina jo atsparumą šalčiui (Kalliopi 2006). 
Cemento akmens poringumas kinta didejant cemento hidratacijos laipsniui. Didejjant cemento hidratacijos laipsniui, mažeja bendrasis ir kapiliarinis poringumas tačiau didejja gelio porų kiekis (Skripkiūnas 2007).

\subsubsection{Betono gamybai naudojami užpildai}

Užpildai - tai inertinis mišinių komponentas, kuris sudaro didžiają mišinio tūrio dalį, net iki $95 \%$. Svarbiausia užpildų paskirtis - užpildyti tūrị mišinyje, sumažinti rišiklio kieki ir pagerinti betono technines savybes (Skripkiūnas 2007; Naujokaitis 2007). Mokslininkas Xing ịvardija, kad užpildas sudaro didžiąją dalį betone ir užima nuo 60 \% iki 80 \% tūrio. Nuo užpildo koncentracijos mišinyje priklauso betono struktūra ir savybès. Užpildai paprastai užpildo betono tūrị, o vienoks ar kitoks rišiklis, kurio tūris mišinyje paprastai būna kelis kartus mažesnis už užpildo tūrį, tik suriša betone užpildo daleles. Gaminant kompozitinius mišinius, būtina ịvertinti komponentų savybes, užpildo daleles, formą, išsidèstymą, paviršiaus šiurkštumą ir kitas sukietejusio kompozito ilgaamžiškukui ịvertinti būtinas savybes. Dažnai siekiama gauti optimalios struktūros mišinị ir reikiamos kokybès betoną. Dažniausiai betone naudojami užpildai yra smèlis, žvirgždas, dolomito skalda, granito skalda ir lengvajam betonui keramzitas (Naujokaitis 2006).

Smèlis yra smulkusis betono užpildas, kurio frakcijos dydis yra nuo $0 \mathrm{~mm}$ iki $4 \mathrm{~mm}$ dydžio. Smèlis yra nuosèdinè uoliena, turinti gana ịvairią mineralinę sudètí, daugiausiai kvarco. Dalelès būna ịvairių formų: kampuotų, apzulintų ir t. t. Cheminè smèlio sudètis pateikta 1.1 lentelèje (Vonsavičius 1961).

1.1 lentelè. Cheminè smèlio sudètis, $\%$

Table 1.1. The chemical composition of the sand, \%

\begin{tabular}{|c|c|c|c|c|c|c|c|c|}
\hline $\mathrm{SiO}_{2}$ & $\mathrm{Al}_{2} \mathrm{O}_{3}$ & $\mathrm{Fe}_{2} \mathrm{O}_{3}$ & $\mathrm{CaO}$ & $\mathrm{MgO}$ & $\begin{array}{c}\mathrm{R}_{2} \mathrm{O}\left(\mathrm{K}_{2} \mathrm{O}\right. \\
\left.+\mathrm{Na}_{2} \mathrm{O}\right)\end{array}$ & $\mathrm{SO}_{3}$ & $\mathrm{CO}_{2}$ & $\begin{array}{c}\text { Kaitinimo } \\
\text { nuostolis, \% }\end{array}$ \\
\hline 93,36 & 3,74 & 0,42 & 0,48 & 0,50 & 1,58 & 0,02 & 0,34 & 0,26 \\
\hline
\end{tabular}

Žvirgždas yra stambusis betono užpildas, kurio frakcijos dydis yra nuo $4 \mathrm{~mm}$. Žvirgždas yra nuosėdinè uoliena, kuri kaip ir smèlis turi įvairią mineralinę sudèti priklausomai nuo vyraujančių uolienų (Naujokaitis 2006).

Dolomitas yra karbonatų klasės kalcito grupès mineralas. Kristalai trigoninès singonijos, romboedro arba daugiakampio pavidalo. Būna ịvairių atspalvių - nuo šviesiai pilkos iki tamsiai pilkos spalvos. Kietumas nuo 3,5 iki 4,0 pagal Moso skalę. Dolomituose $\mathrm{CaCO}_{3}$ vidutiniškai yra 53,13\%, $\mathrm{MgCO}_{3}$ $38,52 \%, \mathrm{SO}_{3}-\mathrm{iki} 3,8 \%$ (Naujokaitis 2006).

Granitas yra magmine intruzine uoliena. Granitas kristalizuojasi iš aukštos temperatūros $600-700{ }^{\circ} \mathrm{C}$ lydalo žemès gelmèse, todèl mineralai suaugę siene- 
lèmis ir labai sukibę - nepažeisto granito poringumas tesiekia $0,01 \%$. Jis sudarytas iš kvarco 20-40\%, feldšpato - ortoklazo 40-70\% ir žèručio - muskovito arba biotito 5-20\%. Dèl to granitas atsparus aukštos temperatūros poveikiui ir turi mažą vandens igeriamumą (igertis $0,2-0,5 \%$ ), yra praktiškai nelaidus vandeniui. Jo kietumas yra nuo 5,5 iki 7,0 pagal Moso skalę (Naujokaitis 2006).

Keramzitas - tai aukštoje temperatūroje degto molio granulès, kurios net keturis kartus lengvesnès už gamtoje randamus analogus. Karjere iškastas įvairių klodų molis maišomas, peršaldomas, džiovinamas, smulkinamas ir paduodamas ị rutulinę krosnị. Joje, esant $1150{ }^{\circ} \mathrm{C}$ temperatūrai, molio žaliava išsipučia, suformuodama kietą išorini paviršių ir porètą vidaus struktūrą turinčias granules (Deltuva 1982, Naujokaitis 2006).

\subsubsection{Priedụ ir cheminių ịmaišu ịtaka betono struktūrai}

Gerinant betono charakteristikas ị betono sudetị įmaišomi įvairūs priedai. Granuliuotų šlakų veikimas cementinèse sistemose yra toks pat, kaip pucolaninių priedų. Tačiau šlakai skiriasi nuo kitu pucolanų, nes jie patys savaime gali kietèti. Nustatyta, kad aukštakrosnių šlako, sumaišyto su portlandcemenčiu ir užpiltu vandeniu, hidratacijos pagrindinis produktas iš esmès lygiai toks pat, kaip ir portlandcemenčio, t. y. kalcio hidrosilikatas $(\mathrm{C}-\mathrm{S}-\mathrm{H})$. Granuliuoto aukštakrosnių šlako hidratacijos produktai paprastai yra gelio pavidalo, priešingai negu portlandcemenčio. Tai irgi didina granuliuoto aukštakrosnių šlako cementinès tešlos tankumą. Granuliuoto aukštakrosnių šlako hidratacija portlandcemenčio aplinkoje didžiąja dalimi priklauso nuo stikliškos šlako struktūros išskaidymo ir ištirpdymo hidroksilo jonais, išlaisvintais portlandcemenčio hidratacijos metu. Hidrolizuojantis granuliuotam aukštakrosnių šlakui, jis reaguoja su šarmais ir kalcio hidroksidu, sudarydamas papildomą kalcio hidrosilikatą (C-S-H). Aukštakrosnių šlakuose $\mathrm{CaO}, \mathrm{SiO}_{2}, \mathrm{Al}_{2} \mathrm{O}_{3}$ ir $\mathrm{MgO}$ suma sudaro nuo $90 \% \mathrm{iki}$ $95 \%$ visos masès. Be to, juose šiek tiek yra $\mathrm{MnO}, \mathrm{FeO}, \mathrm{CaS}, \mathrm{FeS}$ ir kitų oksidų bei sulfidų. Taigi, didelę šlakų dalį sudaro tie patys oksidai, kurie yra ir portlandcemenčio sudètyje, tik čia yra kitoks jų kiekių santykis. Šlakiniam cementui yra būdingos šios savybès (Vektaris et al. 2006):

1. Hidratuojantis šlakiniam cementui, šilumos išsiskiria mažiau ir per ilgesnį laiko tarpą negu hidratuojantis portlandcemenčiui.

2. Šlakinis cementas vadinamas latentine hidrauline rišamaja medžiaga, nes jos hidratacijos periodas ir kietejimo trukmè ištęsti. Jo stipruminès charakteristikos priklauso nuo kietejimo parų skaičiaus ir kinta kitaip negu portlandcemenčio.

3. Atsparus sulfatų ir chloridų tirpalu poveikiui, nes beveik nèra trikalcio aliuminato. Šiam cementui hidratuojantis, susidaro palyginti nedaug kalcio hidroksido, kuris dar reaguoja su šlaku. Dèl to šlakinio cemento 
akmenyje, veikiamame sulfatų ir chloridų tirpalų, nesusidaro ji ardančių junginių.

4. Didesnis vandens nepralaidumas. Cementinis akmuo, susidaręs hidratuojantis tinkamai sumaltam šlakiniam cementui, yra tankus ir laikui bėgant dar tankejja, jame dominuoja smulkiausios poros. Kapiliaru potencialas auga mažejant jų spinduliui, mažo spindulio kapiliarais vanduo ir kiti skysčiai pakyla ị didesnị aukštị kuriose nesusidaro kapiliarinių jègų. Dèl to skiediniai ir betonai su šlakiniu cementu yra nepralaidūs vandeniui ir ịvairiems druskų tirpalams.

Mokslininkai (Pundienè 2000; Demirel el al., 2010) tyrinejo betoną su aliuminatiniu cementu ir $\mathrm{SiO}_{2}$ mikrodulkèmis. Nustate, kad didinant $\mathrm{SiO}_{2}$ mikrodulkiu kieki rišiklio sudetyje, smarkiai padideja V/C santykis. Tai rodo, kad mikrodulkès adsorbuoja vandens perteklių. Nuo mikrodulkių kinta rišimosi pradžios ir pabaigos laikas. I mišini įmaišius $1 \% \mathrm{SiO}_{2}$ mikrodulkių, rišimosi pradžia fiksuojama 150 min. Imaišius 3,2 \% mikrodulkių, rišimosi pradžia fiksuojama 600 min. Gniuždymo stipris priklauso nuo $\mathrm{SiO}_{2}$ mikrodulkių kiekio ir kietējimo trukmès. Po 2-3 paru kietejimo silpniausias bandinys su didžiausiu $\mathrm{SiO}_{2}$ mikrodulkių kiekiu, tačiau po 6-7 parų kietejjimo tokie bandiniai igauna didžiausią gniuždymo stiprị (Pundienè 2000). Mokslininkas pastebèjo, kad betoną veikiančią temperatūrą padidinus nuo $400{ }^{\circ} \mathrm{C}$ iki $800{ }^{\circ} \mathrm{C}$, ultragarso sklidimo greitis sumažèja dvigubai - nuo $3800 \mathrm{~km} / \mathrm{s}$ iki $1800 \mathrm{~km} / \mathrm{s}$ (Demirel el al., 2010).

Mokslininkas tyrinejjo natrio silikato (skystas stiklas) ir jo tirpalo itaką kaitrai atsparaus betono savybėms. Nustatyta, kad nuo skystojo stiklo tankio priklauso bandinio išsiplètimas. Prie $500-600{ }^{\circ} \mathrm{C}$ temperatūros pastebèta, kad mažesnis skystojo stiklo tankis mažiau išplečia medžiagą. Šios reakcijos vyksta dèl kietejjimo metu nesureagavusio rišiklyje skystojo stiklo plèvelių išsipūtimo. Terminis patvarumas kinta nuo natrio silikato kiekio betone. Mažinant kieki nuo $6,5 \%$ iki 3,7\%, terminis patvarumas padidejja nuo 13 iki 20 terminių ciklų, o jų liekamasis stipris siekia 79-87 \% (Antonovič 1999).

Mokslininkas tyrinejo polipropileno ir metalo plaušų ịtaką didelio stiprumo betonuose aukštose temperatūrose. Bandymams panaudotas portlandcementis CEM I, kurio stiprumo klase 52,5, užpildas, superplastiklis „Cimfluid 2002 “, propileno ir metalo plaušas. Buvo pagaminti 4 tipų bandiniai: be papildomų plaušų, su polipropileno plaušais, su metalo plaušais ir su metalo ir polipropileno plaušais. Nustatyta, kad masès nuostolis temperatūros intervale nuo $300{ }^{\circ} \mathrm{C}$ iki $600{ }^{\circ} \mathrm{C}$ kinta tolygiai, tačiau betonuose su polipropileno plaušais yra didesnis. Mechaninès stiprumo savybès betono su polipropileno ir metalo plaušais yra blogesnès už betono su metalo plaušais, tačiau geresnès už betono be plaušų (Pliya 2011). 
Deflokuliantai, kurie vadinami ir plastikliais, ir dispergatoriais, o apibendrintai - reologijos modifikatoriais, naudojami kaitrai atspariuose betonuose jų reologinèms charakteristikoms pagerinti. Šie priedai turi ịtakos betono sklidumui, klojumui, leidžia sumažinti vandens poreikị. Kai kurie deflokuliantai daro itaką cemento hidratacijai, betono tankiui, poringumui ir stiprumui (MartinezRamirez 2001).

Kinų mokslininkų Sun Bei ir Lin Zhixiang darbe analizuotas ultra aukšto stiprumo betono atsparumas skilinèjimui greitai kaitinant ir greitai šaldant. Eksperimentuojant buvo nustatyta ịvairių priedų kiekio ịtaka staigiam šio betono skilinejjimui aukščiau minètomis sąlygomis. Proceso mechanizmas buvo tiriamas išsamia termine ir rentgeno difrakcijos analize bei elektroniniu mikroskopu ir gyvsidabriniu porometru. Tyrejai nustate, kad plieninio plaušo priemaišos prailgino trūkimo laiką, bet neitakojo betono atsparumo pleišejimui. Atsparumas pleišejimui padidejo pridejus polipropileno (PP) ar plieno ir (PP) pluošto. Nustatyta, kad 0,2 \% (nuo tūrio) PP pluošto priedas (12 mm ar $19 \mathrm{~mm}$ ilgio) labai padidina betono atsparumą pleišèjimui. Pagrindinè teigiamo efekto priežastis yra pluošto formuojami cilindriniai kanalai (Bei et al., 2016).

Dispersinès betono komponentų dalelès gali tureti neigiamą arba teigiamą elektros krūvị. Vienodą krūvị turinčios dalelès viena kitą atstumia, o skirtingos viena kitą traukia. Deflokuliantų veikimas grindžiamas vandens ir cemento bei dispersinių dalelių sistemos jègų tarp dalelių pakeitimu. Šis mechanizmas nèra iki galo išaiškintas. Minimi elektrostatinis, erdvinis ir kapiliarinis efektas bei ju deriniai (Martinez-Ramirez 2001).

Kaitrai atspariems betonams gaminti naudojami ịvairūs deflokuliantai: proteinai, lignosulfonatai, melamino-formaldehido dervos, naftaleno sulfonatai, natrio polifosfatai ir poliakrilatai, turintys neigiamą elektros krūvị. Jų veikimas - elektrostatinis dispergavimas, potencialo perstūmimas į neigiamą sritį. Kai betone susidaro pradinių cemento hidratų, tokio tipo deflokuliantai praranda plastifikavimo efektą. Todèl šiuolaikinèse technologijose yra taikomi nauji deflokuliantai, kurie cemento ir vandens sistemoje sukelia dvigubą efektą elektrostatini bei erdvinị. Jų veikimas efektyvesnis, nes nesulimpa cemento dalelès. Šiai grupei priskiriami polikarboksilato eteriai (Goberis et al., 2007).

Orą ịtraukiančios i̇maišos didina oro kieki mišinyje ir sudaro smulkiu sferinių oro porų tinklą. Šios įmaišos didina sukietejjusio mišinio atsparumą šalčiui. Oro ịtraukimas ị mišinį vyksta mišinio maišymo metu. Orą įtraukianti imaiša tik stabilizuoja oro burbuliukus, susidariusius mišinio maišymo metu. Mišinyje be orą įtraukiančios įmaišos oro burbuliukai greitai susijungia ị stambesnius ir pasišalina iš mišinio tankinimo metu. Orą itraukianti įmaiša - tai paviršiaus aktyvinančios medžiagos, kurios absorbuojasi oro ir vandens paviršiuje. Paviršių aktyvinanti medžiaga sumažina paviršiaus ịtempi dujinès ir skystosios fazès paviršiuje, taip apsaugo oro burbuliukus nuo susijungimo ir 
padidina jų stabilumą. Orą ịtraukianti įmaiša įmaišoma ị mišinius kartu su vandeniu labai nedideliais kiekiais $0,3-1,0 \mathrm{ml}$ vienam kilogramui rišiklio masès. Orą įtraukianti įmaiša pagerina ir betono mišinio technologines savybes: padidina mišinio plastiškumą, sumažina sluoksniavimąsi ir vandens atsiskyrimą (Skripkiūnas 2007).

\subsection{Aukštų temperatūrų įtaka betonui}

\subsubsection{Dehidratacijos procesai cementiniame akmenyje}

Veikiant portlandcemenčio akmeni aukštoms temperatūroms, $\mathrm{Ca}(\mathrm{OH})_{2}$ kristalohidratai, kurių dydis siekia $10 \mathrm{~nm}$, kaitinami praranda vandenį ir pasikeičia i $\mathrm{CaO}$ kristalus, kurių būdingasis dydis yra $10^{-3} \mathrm{~nm}$ (Vydra et al. 2001).

Kalcio oksido savitasis paviršius didelis, todè jis iš aplinkos prisisotina drègmès ir pakartotinai hidratuojasi. Antros hidratacijos metu $\mathrm{Ca}(\mathrm{OH})_{2}$ tūris padideja $44 \%$. Toks reiškinys sukelia visišką cementinio akmens irimą (Shui et al. 2009).

Mokslininkai S. Goberis ir V. Antonovič atliko tyrimus. Bandymams buvo panaudotas portlandcementis (CEM I 42,5). Vandens ir cemento santykis 0,25. Cementiniai bandiniai kietejo 7 paras normaliomis sąlygomis, vẻliau buvo degti ịvairiose temperatūrose nuo $300^{\circ} \mathrm{C}$ iki $1200^{\circ} \mathrm{C}$ ir laikomi 3 paras drègnomis sąlygomis. Bandiniai suyra juos išdegus $600{ }^{\circ} \mathrm{C}$ temperatūroje ir palaikius 3 paras drègnomis sąlygomis (Goberis et al., 2007) (1.3 pav.).

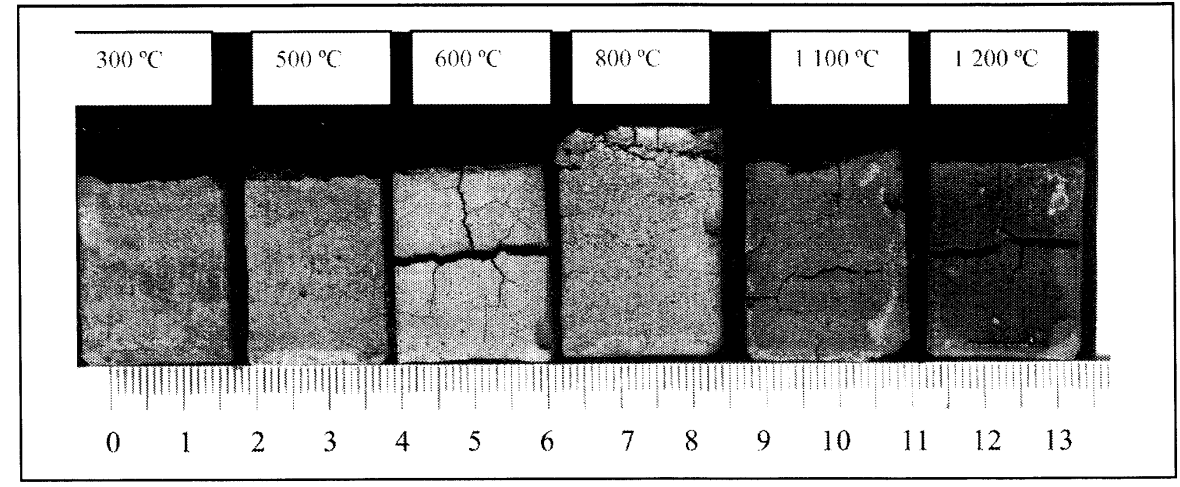

1.3 pav. Portlandcemenčio bandiniai po degimo ir išlaikymo 3 paras drègnomis sąlygomis (Goberis et al., 2007)

Fig 1.3. Portland cement samples after combustion and maintenance for 3 days in humid conditions (Goberis et al., 2007) 
Bandinius išdegus aukštose temperatūrose ir apsaugojus juos nuo drègmès poveikio iš aplinkos gaunami kitokie rezultatai. Bandiniai nesuyra, tačiau jų gniuždymo stipris sumažeja (1.4 pav.).

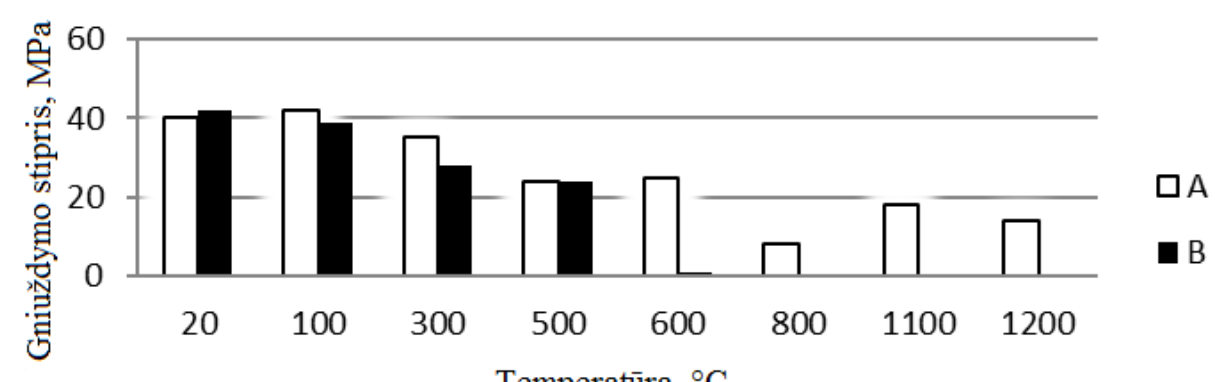

1.4 pav. Portlandcemenčio akmens gniuždymo stipris: A - iškaitintas temperatūroje ir apsaugotas nuo drègmès; B - iškaitintas temperatūroje ir išlaikytas 3 paras drègnomis sąlygomis (Goberis et al., 2007)

Fig. 1.4. Portland stone compressive strength: $\mathrm{A}$ - calcined in temperatures and protected from moisture; B - calcined in temperatures and maintained 3 days in wet conditions (Goberis et al., 2007)

Pateiktame 1.4 paveiksle matome, kad betono bandinius paveikus $500{ }^{\circ} \mathrm{C}$ temperatūra, gniuždymo stipris mažeja apytiksliai dvigubai nuo pradinio stiprio, ir laikymo aplinka po kaitinimo neturi didelès įtakos. Tačiau, betoną paveikus $600{ }^{\circ} \mathrm{C}$ temperatūra, atsiranda žymūs skirtumai, susiję su laikymo sąlygomis po bandymų. Bandiniai praranda gebą atlaikyti apkrovas dèl ịvykusio antrinio hidratacijos proceso, tai yra susidariusio $\mathrm{CaO}$ reakcijos su vandeniu. Virš $500{ }^{\circ} \mathrm{C}$ temperatūros betone pasireiškia žymūs destrukciniai procesai dèl aukščiau minètu priežasčių. Cementinis betonas visiškai praranda stiprumą paveiktas $500^{\circ} \mathrm{C}$ temperatūra (Goberis et al. 2007).

Mokslininkai (Castellote et al. 2004) atliko tyrimus su skirtingais portlandcemenčiais, kuriu skirtingas trikalcio aliuminato $\mathrm{C}_{3} \mathrm{~A}$ kiekis. Pirmasis bandinys turejo $\mathrm{C}_{3} \mathrm{~A}>9 \%$, antrasis $\mathrm{C}_{3} \mathrm{~A}<1 \%$. Bandiniai išlaikomi 28 paras normaliomis sąlygomis. Vèliau buvo kaitinami iki $620^{\circ} \mathrm{C}$ ir normaliomis sąlygomis atvėsinami. Tyrimo rezultatai patvirtina aukščiau aprašytą mechanizmą, kad portlanditas $\mathrm{Ca}(\mathrm{OH})_{2}$, pasiekęs $530-560{ }^{\circ} \mathrm{C}$, skyla ir susidaro kalcio oksidas $(\mathrm{CaO})$. Vèliau aušimo metu kalkès iš aplinkos absorbuoja vandenị ir vèl hidratuoja. Antrą katrą hidratuotas portlanditas yra mažiau kristalizavęsis nei pradinis, ir jo terminio skilimo temperatūra tampa mažesnè. Bandiniuose su trikalcio aliuminato kiekiu $\mathrm{C}_{3} \mathrm{~A}>9 \%$ užfiksuotas mažesnis portlandito suirimas lyginant su trikalcio aliuminato kiekiu $\mathrm{C}_{3} \mathrm{~A}<1 \%$, kai cementinis akmuo suyra visiškai.

Mokslininkas (Arioz 2007) ištyrè keturis skirtingos sudèties betonus skirtingose temperatūrose. Bandymams naudojo portlandcementị, kurio sudètis 
$\mathrm{C}_{3} \mathrm{~S}-38,95 \%, \mathrm{C}_{2} \mathrm{~S}-30,55 \%, \mathrm{C}_{3} \mathrm{~A}-9,91 \%, \mathrm{C}_{4} \mathrm{AF}-11,98 \%$. Užpildui panaudojo susmulkintą kalkakmenį ir upès žvirgždą, kurio didžiausios dalelès siekè $15 \mathrm{~cm}$. Bandymams buvo paruošti $70 \times 70 \times 70$ kubiniai bandiniai, kurie 28 paras laikomi vandenyje, vèliau 6 paras džiovinami aplinkos temperatūroje ir vieną parą laikomi krosnelèje prie $105{ }^{\circ} \mathrm{C}$. Bandiniai kaitinami ir išlaikomi norimoje temperatūroje 2 valandas. Temperatūros kilimo greitis $20{ }^{\circ} \mathrm{C} / \mathrm{min}$. Fiksuojamas paviršiaus pleišejimas (1.5 pav.), masès nuostoliai ir gniuždymo stipris. Masès nuostoliai iki $800{ }^{\circ} \mathrm{C}$ didèja tolygiai iki $10 \%$. Nuo $800{ }^{\circ} \mathrm{C}$ iki $1200{ }^{\circ} \mathrm{C}$ betono masès nuostolis didèja greitai ir siekia $40 \%$. V/C santykis masès nuostoliams įtakos neturi. Gniuždymo stipris prie $800{ }^{\circ} \mathrm{C}$ sumažejja $60 \%$, prie $1200^{\circ} \mathrm{C}$ temperatūros bandinys suyra.
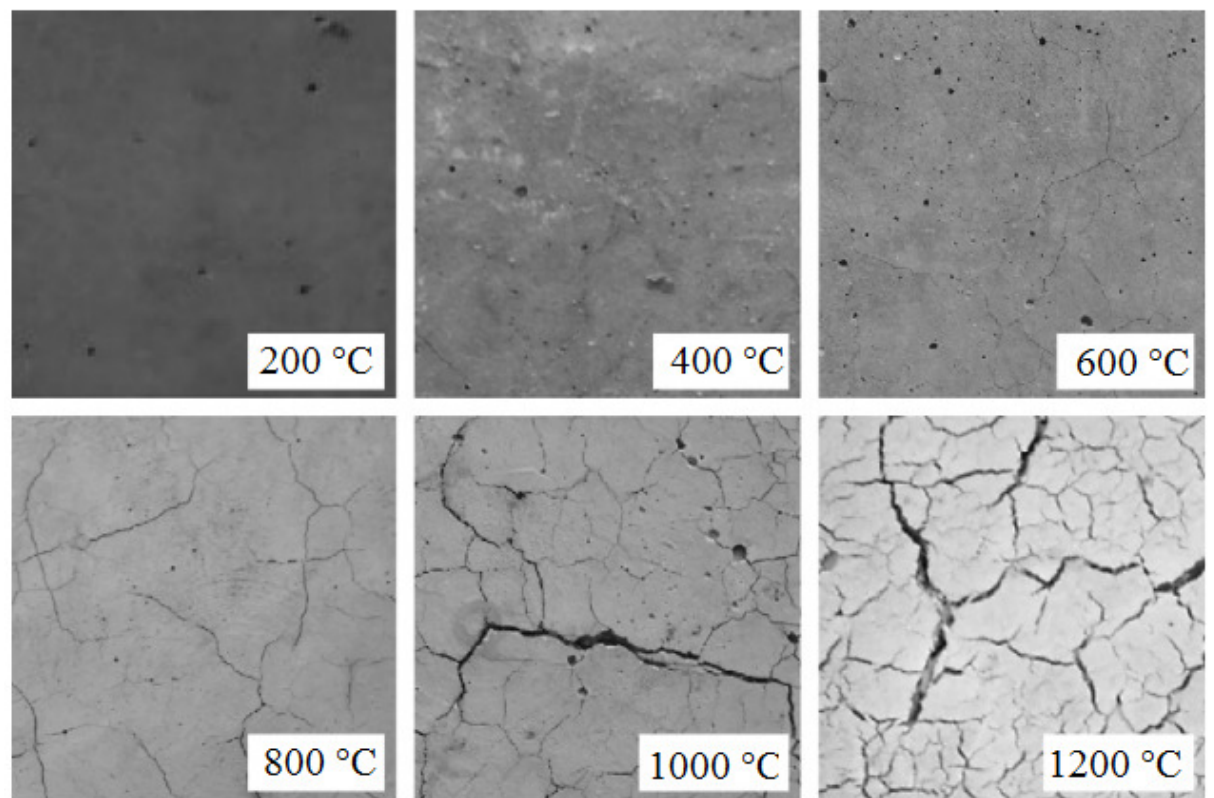

1.5 pav. Paviršiaus ịtrūkimai prie skirtingų temperatūrų (Arioz 2007)

Fig. 1.5. Surface cracking with different temperatures (Arioz 2007)

1.6 paveiksle pateikta cementinio akmens termograma. Analizuojant šios termogramos kreives galima padaryti išvadą, kad pirmasis $\left(130{ }^{\circ} \mathrm{C}\right.$ temperatūros) endoefektas apibūdina adsorbcinio vandens pašalinimą iš gelio pavidalo kalcio hidrosilikatu ir etringito, $170{ }^{\circ} \mathrm{C}$ temperatūros endoefektas apibūdina heksagonalinio hidroaliuminato suirimą, $470{ }^{\circ} \mathrm{C}$ temperatūros endoefektas apibūdina kalcio hidrosilikatų dehidrataciją ir pasiektas $760{ }^{\circ} \mathrm{C}$ temperatūros endoefektas apibūdina kalcio karbonato disociaciją. TG kreivè rodo masės nuostolius yrant cheminiams junginiams (Šiaučiūnas et al. 2007). 


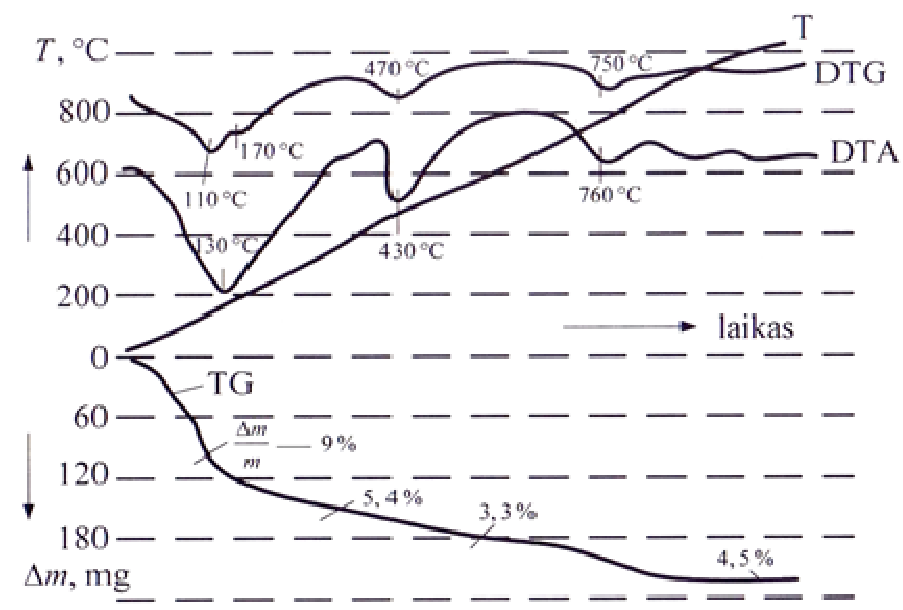

1.6 pav. Cementinio akmens termograma (Šiaučiūnas et al. 2007)

Fig. 1.6. Thermogram of cement stone (Šiaučiūnas et al. 2007)

Mokslininkas (Monteagudo et al. 2014) nagrinejjo cementinès tešlos hidratacijos laipsni su skirtingais priedais. Bandymai atlikti su aukštakrosniu šlaku, pelenais, silicio mikrodulkèmis. Pateikiamos išvados, kad termogravimetija galima kiekybiškai nustatyti hidratacijos laipsni pagal chemiškai surišto vandens santykị su portlanditu.

Termogravimetrijos metodas buvo pritaikytas betono lydymosi temperatūrai nustatyti. Mokslininkas (Hojae et al., 2016) nagrinejo betoną su skirtingais užpildais. Jis tyrẻ betoną su bazaltu, kalkakmeniu, silicio užpildu ir nustatè, kad betonas su bazalto užpildu lydosi prie $1377{ }^{\circ} \mathrm{C}$, su kalkakmeniu prie 1295 $1427{ }^{\circ} \mathrm{C}$ priklausomai ar smulkus, ar stambus pasirinktas užpildas. Šie tyrimai bus pritaikyti atominių reaktorių pagrindų gamybai.

\subsubsection{Betono užpilduose vykstantys fizikiniai ir cheminiai procesai aukštose temperatūrose}

Betono gamybai visais atvejais naudojamas smulkusis užpildas, kuris dažniausiu atveju būna smèlis. Smèlis yra nuosèdinè uoliena, turinti gana ịvairią mineralinę sudèti, daugiausiai kvarco. Kvarcas yra silicio dioksido mineralas, kuris prie $573{ }^{\circ} \mathrm{C}$ temperatūros deformuojasi ir keičia kristalinę gardelę iš betą i alfą, taip didindamas savo tūrị $1,5 \%$, kaitinamas $870{ }^{\circ} \mathrm{C}$ temperatūroje kvarcas virsta tridimitu ir dar padidina tūrị (Deltuva et al. 1982).

Mokslinikas (Arioz 2007) atliko tyrimus su paprastu portlandcemenčiu, panaudojant užpildus - trupintą kalkakmenị ir upès žvirgždą. Betono bandinius paveike temperatūra nuo $200{ }^{\circ} \mathrm{C}$ iki $1200^{\circ} \mathrm{C}$. Mokslininkas pastebejjo, kad paveikus $600{ }^{\circ} \mathrm{C}$ temperatūra, bandiniai vizualiai sutrūkinèjo, paveikus $800{ }^{\circ} \mathrm{C}$ 
temperatūra, bandiniai žymiau sutrūkinèjo, paveikus betono bandinius $1200{ }^{\circ} \mathrm{C}$ temperatūra, bandiniai visiškai suiro. Aukštose temperatūrose bandiniai su upès žvirgždu vertinant stiprumines savybes pasirodè blogiau. Mokslininkas (Xing et al., 2015) iš Prancūzijos nagrinèjo termofizikines užpildų savybes veikiant temperatūrai. Jis atliko bandymus su kvarcitu, titnagu ir kalkakmeniu. Taip pat teigia, kad užpildo mineralinè sudètis labai įtakoja betono šiluminị laidumą. Bazaltas turi mažą pralaidumą, klintys ir dolomitas vidutinị, kvarcas ir smiltainis aukštesnị pralaidumą. Mokslininkai ịvardina nerūdinių iškasenų šiluminị laidumą nuo $1 \mathrm{~W} / \mathrm{mK}$ iki $9 \mathrm{~W} / \mathrm{mK}$ (Marshall 1972; Khan et al.1995; Zoldners 1971).

\subsubsection{Betono sprogstamoji irtis}

Kaitinant betoną galimas srogstamasis efektas. Mokslininkai (Matesova et al. 2006; Mindeguia et al. 2010; John et al. 2013) teigia, kad sprogstamasis efektas galimas prie žemesnių kaip $200{ }^{\circ} \mathrm{C}$ temperatūrų. Kiti autoriai (Hertz 2003; Kumar et al. 2006) ìvardina temperatūras nuo $200-350{ }^{\circ} \mathrm{C}$. Gawin ir kt., kad sprogstamasis efektas pasireiškia esant tokiai temperatūrai (Gawin et al. 2006).

Didelio stiprumo betonas turi didesnę tendenciją sproginèti, nei normalaus stiprumo betonas. Anderberg nurodo, kad paviršiaus trūkinèjimas didèja didèjant betono drégnumui, betono nepralaidumui, išorinès apkrovos gniuždymui, temperatūros greičiui, nesimetrinès temperatūros pasiskirstymui. Betono sprogstamoji irtis yra susijusi su vandens garų slègiu betone. Kaitinant betoną laisvasis vanduo kaista ir garuoja, nesant salygų vandeniui išgaruoti (uždaros poros) atsiranda didelis slègis (Anderberg 1997).

Autoriai Phan ir Carino pateikia tokias išvadas (Phan et al.1998):

- betono sproginèjimas vyksta prie $200-325^{\circ} \mathrm{C}$ temperatūros;

- išankstinè apkrova sušvelnina sproginèjimą;

- betono bandiniai su mažesniu V/C santykiu turèjo didesni potencialą sproginèti nei bandiniai su didesniu V/C santykiu. Tačiau, kai bandymai buvo pakartoti esant švelnesnèms sąlygoms, sprogstamoji irtis pastebèta tik bandiniuose su didesniu V/C santykiu. Bandiniai, pagaminti su V/C 0,57, išvis netrūkinèjo išbandant visomis sąlygomis;

- $\mathrm{SiO}_{2}$ mikrodulkès neturejo žymios įtakos bandinių sproginejjimui.

Mokslininko Mindeguia straipsnyje įvardinamos priežastys (Mindeguia et al. 2010):

- betono vandens laidumas stipriai itakoja vandens skverbimosi greiti kaitinimo metu;

- užpildo terminis nestabilumas padidina atskirų fragmentų atsiradimo galimybę; 
- $\quad$ porų slègi betone sukelia vandens garai. Maksimalus slègis labai priklauso nuo betono mišinio sudeties. Mažas betono pralaidumas sudaro sąlygas didelio slègio atsiradimui porose. Tai seka ir iš P. Laplaso viršslègio lygties, priklausomai nuo porų ir kapiliarų spindulių verčių (Мачюлайтис 1997).

\subsection{Gelžbetonio atsparumo ugniai vertinimo charakteristikos}

Gaisrinès saugos pagrindiniai reikalavimai nurodo, kad kilus gaisrui turi būti apribota rizika žmonių saugai, visuomeniniam ir kaimynų turtui bei aplinkai (LR įsakymas Nr. 1-338 2011).

Rengiant ir projektuojant statinio konstrukcijas, reikia įvertini konstrukcinès sistemos elgseną veikiant gaisro temperatūroms, galimą šilumos poveikị ir teigiamas aktyvių bei pasyvių apsaugos priemonių poveikį gaisro metu. Laikančios konstrukcijos be gaisro atskyrimo funkcijų turi būti projektuojamos taip, kad atlaikymo funkcija R (geba atlaikyti apkrovas) būtų pakankama. Konstrukcijose, kurios projektuojamos gaisro atskyrimo funkcijai užtikrinti, turi būti vertinamas kriterijus E (sandarumas), neturi atsiverti plyšiai, susidaryti skylès, kad gaisro sąlygomis neuždegtu konstrukcijos iš neveikiamos pusès ir taip ribotu gaisro plitimą (Jonaitis et al. 2005). Gaisro metu patalpoje temperatūra gali pakilti iki $1200{ }^{\circ} \mathrm{C}$, pramoniniuose pastatuose ir dar aukščiau. Tokia aukšta temperatūra gali išsilaikyti iki 3 valandų ir ilgiau. Veikiant pastato konstrukcijas tokia aukšta temperatūra ir ilgą laiką, konstrukcijos smarkiai pažeidžiamos. Pažeistos konstrukcijos gali nebeatlaikyti apkrovų, arba jų tolimesnis eksploatavimas tampa negalimas. Siekiant sumažinti gelžbetoninių konstrukcijų pažeidimus gaisro metu, būtina tinkamai ịvertinti gaisro metu vyraujančius procesus. Gelžbetoninių konstrukcijų analizė gaisro metu yra svarbi projektavimo dalis, tačiau elementų elgsena gaisro metu yra labai sudètinga. Skaitiniams metodams reikia daug kompiuterinių išteklių, todèl jų taikymas yra ribotas netgi sudètingomis gelžbetoninių konstrukcijų skaičiavimo programomis (Gribniak et al. 2006). Gelžbetonis yra kompleksinè medžiaga ir jo komponentai - betonas ir plienas - $\mathfrak{i}$ aukštą temperatūrą reaguoja skirtingai. Siekiant tiksliau atlikti vertinimus, reikalinga atskirai vertinti betono ir plieno fizines bei mechanines savybes.

Betoną paveikus aukšta temperatūra kinta jo savybès: tankis, gniuždymo stipris, išauga plastinès deformacijos, keičiasi specifinè betono šiluma ir šilumos laidumas (Eurokodas 2-1-2:2005).

Armatūrinių plienų takumo aikštelè, didejjant temperatūrai, mažèja. Pasiekus $300{ }^{\circ} \mathrm{C}$ temperatūrą ji visiškai pradingsta. Dauguma plienų, naudojamų 
gelžbetoninèse konstrukcijose, yra plastiški. İkaitintos plieninès armatūros mechaninès savybès blogèja. $200-350^{\circ} \mathrm{C}$ temperatūroje S240 klasès armatūra šiek tiek sustipreja, prie $400{ }^{\circ} \mathrm{C}$ temperatūros stiprumas ir takumo riba stipriai sumažèja, tačiau išauga plastiškumas. Plieninès armatūros su legiruotais plienais S600, S800 elgiasi labai panašiai kaip ir angliniai plienai, jų takumo riba taip pat mažeja (Eurokodas 2-1-2:2005).

Veikiant gelžbetoninę konstrukciją aukštai temperatūrai, betonas traukiasi, o plieninè armatūra, turèdama didesni plètimosi koeficientą, plečiasi. Tokioje kompozicijoje susidaro priešingos jègos, kurios eigoje betonas su armatūra gali prarasti sukibtị. Kylant temperatūrai betono ir armatūros sukibtis mažèja, esant $100{ }^{\circ} \mathrm{C}$ temperatūrai lygaus paviršiaus armatūra su sunkiuoju betonu praranda $25 \%$ sukibties. Sunkiojo betono sukibtis su karštai valcuota rumbuota armatūra prie $350{ }^{\circ} \mathrm{C}$ temperatūros yra didesnè, tačiau pasiekus $450{ }^{\circ} \mathrm{C}$ temperatūrą yra prarandama $25 \%$ sukibtis (Ильин 1979).

Standarto LST EN 13369:2013 „Bendrosios surenkamų betoninių gaminiu taisyklès“ 4.3.punktas numato, kad atsparumas ugniai pagal gaisro plitimo parametrus gali būti vertinamas pagal apskaičiavimo metodus, pateiktus LST EN 1992-1-2 (Eurokodas 2), arba pagal bandymus.

Mokslininkai (Bamonte et al. 2015) savo straipsnyje pažymi, kad betono elgsena aukštoje temperatūroje išsamiai tiriama nuo 1970 m., siekiant išskirti pagrindines problemas, susijusias su jo mechaninèmis savybėmis aukštos temperatūros sąlygomis, pavyzdžiui, vykstant cheminiams procesams, kinematinei elgsenai (trumpalaikès ir dèl valkšnumo kylančios deformacijos) bei fizikiniųmechaninių savybių evoliucijai. Šių tyrimų dèka literatūroje apie betono elgseną aukštoje temperatūroje buvo pateikti esminiai modeliai/fizikinio proceso aprašymo modeliai, siekiant pademonstruoti galimą gelžbetonio konstrukcijos elgseną ją kaitinant. Atsižvelgiant ị šį kontekstą, naudojant FORTRAN uždavinių sprendimo priemonę bei GID kaip parengiamąją ir baigiamają sistemą, buvo sukurtas Sijos baigtinio elemento metodas termomechaninèms analizėms atlikti. Skaitiniu būdu buvo sumodeliuota daug kruopščiai sudokumentuotu išsamių bandymų su gelžbetoninèmis kolonomis, paveiktomis standartinio gaisro, igyvendinant keturis skirtingus esminius modelius apie betono elgseną aukštoje temperatūroje, siūlomus literatūroje. Pagrindiniai tikslai: pabrež̌ti kai kurių itin svarbių aspektų vaidmeni gelžbetoninių elementų elgsenai karštos būsenos sąlygomis, ypač antrinị poveikị, trumpalaikę ir dèl valkšnumo kylančią deformaciją ir atlikti sistemini palyginimą tarp skaitinių ir eksperimentinių rezultatų, siekiant ịvertinti ir 1D skaitinio modeliavimo, ir jau pasirinktu esminių betono modelių patikimumą. Gauti rezultatai patvirtina, kad 1D skaitinis modeliavimas iš esmès atitinka eksperimentinius duomenis, jei atsižvelgiama $i$ trumpalaikes ir dèl valkšnumo kylančias deformacijas, taip pat $\mathfrak{i}$ antrini po- 
veikį. Be to, skirtumai tarp tirtų keturių modelių, demonstruojančių betono elgseną gniuždymo atveju, yra gana nedideli.

Mokslininkai bandymo metu tyrè deformavimo greičio poveiki aukštesne temperatūra paveikto didelio stiprumo betono elgseną. Betono prizmès buvo kaitinamos iki $20^{\circ} \mathrm{C}, 200{ }^{\circ} \mathrm{C}, 400{ }^{\circ} \mathrm{C}, 600^{\circ} \mathrm{C}$ ir $800{ }^{\circ} \mathrm{C}$ temperatūros. İkaitintos prizmès buvo paveiktos ašine apkrova, deformacijos greitis $10^{-5} \mathrm{~s}^{-1}$, ir atitinkamai dviem pakartotiniais seisminiais smūgiais dinaminiu deformavimo greičiu $10^{-3}$ ir $0,067 \mathrm{~s}^{-1}$. Bandymų rezultatai rodo, jog kuo aukštesnè temperatūra ir deformavimo greitis, tuo daugiau bus ịtrūkimų ir nuotrupų. Tiek liekamasis gniuždymo stipris, tiek tamprumo modulis mažès kylant temperatūrai. Be to, maksimalią deformaciją sustiprina padidintos temperatūros, tačiau labai ženkliai įtakoja deformavimo greitis. Nustatytas santykis tarp įtempio ir deformacijos bei dinamiško apkrovimo faktoriaus (Jianzhuang et al. 2016).

Jei atlikdami terminę analizę nenorime nuvertinti žalos, kurią gaisro atveju tunelio betoninei dangai padaro sukelta aukšta temperatūra, svarbu ịvertinti skerspjūvyje prarandamą betono dangą. Šiame tyrime skaitinès analizès būdu, taikant elementų pašalinimo modelị bei kombinuoto šilumos perdavimo koeficientą, imituojamas konstrukcijos nuostolis. Buvo atlikta gaisro bandymų serija naudojant standartinio gaisro kreives, kurios skyrèsi pradinès temperatūros gradientu bei maksimalia temperatūra. Optimizuoto kombinuoto šilumos perdavimo koeficiento vertès paimtos iš sutapusių skaitinès analizès rezultatų bei eksperimentų metu gautų duomenų. Rezultatai atskleidžia, kad tiek pradinès temperatūros gradientas, tiek maksimalios temperatūros didèjimas sukelia didelę žalą betoninèms konstrukcijoms. Taip pat gali įtakoti šilumos perdavimo koeficiento padidejimą. Konstrukcijos betono nuostolio atveju kombinuoto šilumos perdavimo koeficiento vertes galima nustatyti iš pradinès temperatūros gradiento bei maksimalios temperatūros verčių. Nepriklausomai nuo to, ar patirtas betono konstrukcijos nuostolis, ar ne. Iš rezultatų buvo išvestos dvi regresijos lygtys. Kalbant apie tikslų pastebètų rezultatų imitavimą, siūlomas terminès analizès metodas, kuris pranašesnis lyginant su tradiciniu metodu (Soo-Ho el al. 2016).

\subsection{Apsauginio betono sluoksnio storio iki armatūros vertinimas}

Elementams veikiant gaisro temperatūrai skaičiuoti taikomi keli metodai (Eurokodas 2-1-2:2005):

- projektavimas naudojantis lentelių duomenimis;

- paprastieji skaičiavimo metodai (taikomi tik tam tikriems elementams, veikiant tik lenkimo momento ir ašinèms jègoms). 
Paprastuoju skaičiavimo metodu nustatoma kaitinamojo skerspjūvio laikomoji geba. Šis metodas taikomas konstrukcijoms, paveiktoms standartine gaisro kreive iki didžiausios gaisro temperatūros. Šiuo metodu vertinamas temperatūrinių laukų pasiskirstymas pjūviuose, betono ir armatūros stipris, tamprumo modulis. Apskaičiuojama laikomoji geba ịvertinus sumažintą skerspjūvị. Elementai turi būti suprojektuoti taip, kad neatplyštu apsauginis betono sluoksnis, nesuirtų dèl sprogstamojo betono irimo, nepasižeistų armatūros inkaravimo vietos (Jonaitis et al. 2005).

Mokslininkai (Ibanez et al., 2015) straipsnyje nagrinejja realistinio skerspjūvio temperatūros prognozavimo metodą bei supaprastintas apvalaus skerspjūvio, betonu užpildytų vamzdinių kolonų, veikiamų ašine apkrova elgsenos ugnyje skaičiavimo metodą. Jie teigia, kad labai trūksta paprastų pasiūlymų, kaip apskaičiuoti betonu užpildytų vamzdinių kolonų temperatūros pasiskirstymo laukus, kai vertinamas ju atsparumas ugniai. Netgi Eurokodas 4-1-2, kuris nurodo vieną iš labiausiai naudojamų kompozicinių kolonų elgsenos ugnyje skaičiavimo metodų, nepateikiama jokių nuorodų projektuotojams, kaip skaičiuoti skerspjūvių temperatūrą. İvertinant, jog tam būtina turèti veikiantị metodą, šiame straipsnyje pateikiamos lygtys, padèsiančios apskaičiuoti temperatūros pasiskirstymą apvaliose, užpildytose ịprastinio stiprumo betonu kolonose. Gauti praktinès išraiškos rezultatai. Antroje darbo dalyje nagrinejjamas ašine apkrova veikiamų ašies kryptimi apkrautų kolonų elgsenos ugnyje skaičiavimo metodo vystymas, remiantis bendrosiomis Eurokodo 4-1-1 dalyje nustatytomis taisyklèmis bei pasitelkiant bendrą supratimą apie betono šerdies skerspjūviui ekvivalentišką kambario temperatūros koncepciją. Siekiant pateikti paprastas formules, atlikta daugialypé netiesinés regresijos analizè, kuriai buvo panaudoti termomechaninių parametrų analizès būdu gauti skaitiniai rezultatai. Prognozuojami rezultatai dar kartą palyginami su gautomis eksperimentinemis vertémis bandymų metu, užtikrinant pagrịstą tikslumą.

Norint tiksliai prognozuoti atsparumą ugniai, ypatingai svarbu tiksliai prognozuoti skerspjūvio temperatūras betonu užpildytuose plieno tuščiaviduriuose profiliuose. Nors su betonu užpildytomis plieno kolonomis buvo atlikta daug terminių bei konstrukcinių bandymų, yra keletas, kurie pateikia pilną ataskaitą apie skerspjūvio šilumos lauko parametrų profilį, tačiau šie modeliai nepatvirtinti. Mokslininkai (Rush D. et al. 2015) nustatè, kad: dèl Eurokodo gairių galima smarkiai pervertinti skerspjūvio temperatūras; siūlomos naujos terminio modeliavimo prielaidos trijose pagrindinèse srityse; ir priešgaisrinès elgsenos ugnyje skaičiavimo gairès yra labai konservatyvios. 


\subsection{Pirmojo skyriaus išvados ir disertacijos uždavinių formulavimas}

1. Betonas su mineraliniais priedais bei cheminèmis imaišomis yra kompozitinè medžiaga, kurioje yra skirtingų hidratacijos produktų ir struktūrų, todèl vertinti gaminių atsparumą ugniai yra labai sudètinga.

2. Didžiają tūrio dalị betone sudaro užpildai, kurie daro įtaką betono elgsenai veikiant aukštai temperatūrai. Užpilde esantis kvarco mineralas prie $573{ }^{\circ} \mathrm{C}$ temperatūros keičia savo kristalinės gardelès struktūrą iš $\beta$ i $\alpha$, kvarco tūris padideja apie $1,5 \%$, o prie $870{ }^{\circ} \mathrm{C}$ temperatūros kvarcas virsta tridimitu, jo tūris dar padidejja. Užpilduose esantys karbonatai $\left(\mathrm{CaCO}_{3}\right.$ ir $\left.\mathrm{MgCO}_{3}\right) 650-800{ }^{\circ} \mathrm{C}$ temperatūros intervale dekarbonizuojasi susidarant $\mathrm{CaO}$ ir $\mathrm{CO}_{2}$, pasireiškiant dideliems masès nuostoliams.

3. Orą ịtraukiančios cheminès i̇maišos gali reguliuoti porų struktūrą ir vidinius betono įtempius užšaldymo metu. Lig šiol nebuvo nagrinèjama oro kiekio itaka betono intensyviam kaitinimui iki aukštų temperatūrų, t. y. atsparumui ugniai.

4. Projektuojant gelžbetonines konstrukcijas pagal šiuo metu galiojančius standartus, atsparumas ugniai vertinamas pagal apsauginio sluoksnio stori, neatsižvelgiant į betono charakteristikas.

Apibendrinus kitų autorių tyrimus ir norint nustatyti cemento tipo, užpildų ir oro kiekio mišinyje įtaką betono atsparumui ugniai reikia išspręsti disertacijoje tokius uždavinius:

1. Nustatyti skirtingų cementų, užpildų ir ịtraukto oro kiekio įtaką temperatūrų pasiskirstymui kaitinamo betono skerspjūvyje.

2. Ištirti irimo procesus dèl temperatūrinio poveikio betone su skirtingais cementais bei užpildais.

3. Nustatyti oro kiekio betono mišinyje itaką betono mikrostruktūros bei fizikinių mechaninių savybių pokyčiams veikiant aukštai temperatūrai.

4. Atlikti temperatūrinio rèžimo betone gaisro metu prognozavimą ir nustatyti naudotinas betono gamybai žaliavas bei reikiamą oro kieki betono mišinyje. 


\section{2}

\section{Tyrimams naudotos medžiagos ir atsparumo ugniai bandymu metodikos}

Šiame skyriuje aprašomos tyrimams naudotos medžiagos ir bandiniai, jų paruošimas, apžvelgiami visi bandymų metodai ir bandymų įranga, kurie buvo naudoti tiriant betono ir cementinio akmens atsparumą ugniai.

Šio skyriaus medžiaga paskelbta dvejuose straipsniuose (Jocius et al. 2013; Jocius et al. 2014) ir pristatyta keturiose mokslinèse konferencijose.

\subsection{Medžiagos ir jų charakteristikos}

Bandymams naudotas portlandcementis su skirtingais mineraliniais priedais: CEM I 42,5 R (be priedų, smulkiai maltas), CEM I 42,5 N (be priedų), CEM II/A-LL 42,5 N (su $17 \%$ klinčiu priedu), CEM II/A-S 42,5 N (su $17 \%$ aukštakrosniu šlako priedu), CEM III/B 32,5 N (su 70 \% aukštakrosniu šlako prie$\mathrm{du})$, gamintojas $\mathrm{AB}$, ,Akmenès cementas“. Cementai atitinka standarto LST EN 197-1:2011 reikalavimus. Gamintojo deklaruojama portlandcemenčio klinkerio cheminè ir mineralinè sudetis pateikta 2.1 lenteleje, cemento mechaninès ir fizikinès savybės 2.2 lentelèje. 
2.1 lentelè. Portlandcemenčio klinkerio cheminè ir mineralinė sudètis

Table 2.1. Portland cement clinker chemical and the mineral composition

\begin{tabular}{|c|c|c|c|}
\hline Cheminè sudetis & Kiekis, \% & Mineralinè sudètis & Kiekis, \% \\
\hline $\mathrm{SiO}_{2}$ & 20,48 & $\mathrm{C}_{3} \mathrm{~S}$ & 56,60 \\
\hline $\mathrm{Al}_{2} \mathrm{O}_{3}$ & 5,55 & $\mathrm{C}_{2} \mathrm{~S}$ & 15,76 \\
\hline $\mathrm{Fe}_{2} \mathrm{O}_{3}$ & 3,58 & $\mathrm{C}_{3} \mathrm{~A}$ & 8,59 \\
\hline $\mathrm{CaO}$ & 63,13 & $\mathrm{C}_{4} \mathrm{AF}$ & 10,85 \\
\hline $\mathrm{SO}_{3}$ & 0,73 & - & - \\
\hline $\mathrm{Cl}^{-}$ & 0,002 & - & - \\
\hline $\mathrm{MgO}$ & 3,99 & - & - \\
\hline $\mathrm{CaO}_{\text {laisvo }}$ & 0,86 & - & - \\
\hline
\end{tabular}

2.2 lentelè. Cemento mechaninès ir fizikinès savybès

Table 2.2. Cement mechanical and physical properties

\begin{tabular}{|c|c|c|c|c|c|}
\hline Cemento savybès & $\begin{array}{c}\text { CEM I } \\
42,5 \mathrm{~N}\end{array}$ & $\begin{array}{c}\text { CEM I } \\
42,5 \mathrm{R}\end{array}$ & $\begin{array}{c}\text { CEM II /A- } \\
\text { LL 42,5N }\end{array}$ & $\begin{array}{c}\text { CEM } \\
\text { II/A-S } \\
42,5 \mathrm{~N}\end{array}$ & $\begin{array}{c}\text { CEM III/B } \\
32,5 \mathrm{~N}-\mathrm{LH}\end{array}$ \\
\hline $\begin{array}{c}\text { Gniuždymo stipris } \\
\text { po 2 paru, MPa }\end{array}$ & $22 \pm 3$ & $28 \pm 2$ & $21 \pm 3$ & $22 \pm 3$ & - \\
\hline $\begin{array}{c}\text { Gniuždymo stipris } \\
\text { po 28 paru, MPa }\end{array}$ & $50 \pm 3$ & $54 \pm 3$ & $47 \pm 3$ & $51 \pm 3$ & $41 \pm 3$ \\
\hline $\begin{array}{c}\text { Rišimosi pradžia, } \\
\text { min }\end{array}$ & 160 & 160 & 190 & 160 & 220 \\
\hline $\begin{array}{c}\text { Rišimosi pabaiga, } \\
\text { min }\end{array}$ & - & - & - & - & 315 \\
\hline $\begin{array}{c}\text { Tūrio pastovumas, } \\
\mathrm{mm}\end{array}$ & $<1,0$ & $<1,0$ & $<1,0$ & $<1,0$ & $<1,0$ \\
\hline $\begin{array}{c}\text { Vandens sąnaudos, } \\
\%\end{array}$ & 24,3 & 25,1 & 25,0 & 25,3 & 30,3 \\
\hline $\begin{array}{c}\text { Liekana ant sieto } 90 \\
\mu \mathrm{m}, \%\end{array}$ & 3,5 & 1,5 & 4,3 & 2,9 & 0,3 \\
\hline $\begin{array}{c}\text { Savitasis paviršius, } \\
\mathrm{cm} \text { /g }\end{array}$ & 3500 & 3700 & 3600 & 3500 & 5000 \\
\hline
\end{tabular}

Smulkiajam užpildui buvo naudotas šamotas frakcija 0/4 ir gamtinis smèlis frakcija 0/4. Šamotas buvo naudotas, kaip termiškai stabilus užpildas atliekant cemento su skirtingais mineraliniais priedais tyrimus. 
Šamotas „Grade -Bos 125“ iš Lenkijos įmonès T-Ozmo. Gamintojo deklaruojami parametrai: frakcija $0 / 4$, naudojimo temperatūra $1250{ }^{\circ} \mathrm{C}$, šamoto mineralinę sudètị sudaro aliumosilikatiniai junginiai, $\mathrm{Al}_{2} \mathrm{O}_{3}$ kiekis $29 \%$, igeriamo vandens kiekis $10-12 \%$. Granuliometriniai tyrimų rezultatai pateikti 2.1 paveiksle.

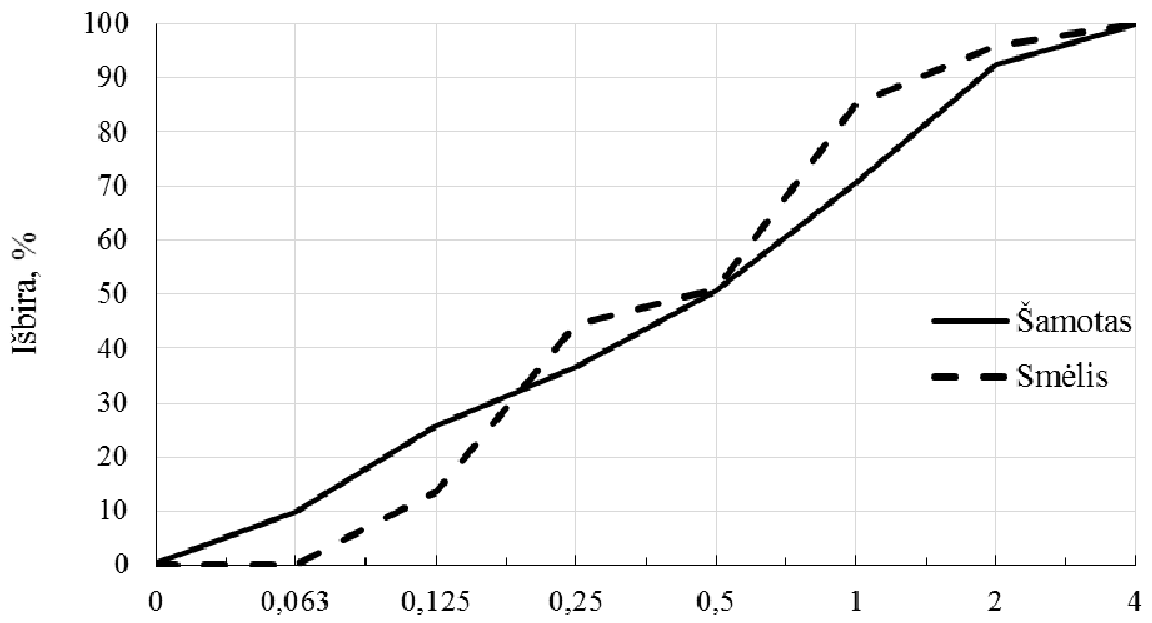

Sietų akučių dydis, mm

2.1 pav. Šamoto ir smèlio granuliometrinè sudètis

Fig. 2.1. The granulometric composition of chamotte and sand

Smèlis (UAB „Poškų karjeras“, Poškų k., Agluonėnų sen., Klaipėdos r.), tenkinantis LST EN 12620:2003+A1:2008 standarto reikalavimus. Gamintojo deklaruojami smèlio fizikinių savybių rodikliai (2.3 lentelè), jo cheminė (2.4 lentelè) bei granuliometrinè sudètis pateikta 2.1 paveiksle.

Smèlio mineralinè-petrografinè sudètis: kvarcas - $60,4 \%$, lauko špatai $12,1 \%$, karbonatai $-15,9 \%$, žèrutis $-0,1 \%$, tamsieji mineralai $-4,0 \%$, kristalinès uolienos $7,5 \%$.

2.3 lentelè. Smèlio fizikinès savybès

Table 2.3. Sand physical properties

\begin{tabular}{|c|c|c|}
\hline Charakteristika & Frakcija & Vidutinè verte \\
\hline Dalelių tankis, $\mathrm{kg} / \mathrm{m}^{3}$ & $0 / 4$ & 2649 \\
\hline Vandens i̇mirkis, \% & $0 / 4$ & 0,59 \\
\hline Piltinis tankis, $\mathrm{kg} / \mathrm{m}^{3}$ & $0 / 4$ & 1669 \\
\hline
\end{tabular}


2.4 lentelè. Cheminè smèlio sudètis

Table 2.4. The chemical composition of the sand

\begin{tabular}{|c|c|c|c|c|c|}
\hline $\mathrm{SiO}_{2}, \%$ & $\mathrm{Al}_{2} \mathrm{O}_{3}, \%$ & $\mathrm{Fe}_{2} \mathrm{O}_{3}, \%$ & $\mathrm{CaO}, \%$ & $\mathrm{MgO}, \%$ & $\begin{array}{c}\text { Kaitinimo } \\
\text { nuostolis, \% }\end{array}$ \\
\hline 77,87 & 4,86 & 0,98 & 6,84 & 0,45 & 5,35 \\
\hline
\end{tabular}

Žvirgždas (UAB „Poškų karjeras“, Poškų k., Agluonènų sen., Klaipèdos r.), tenkinantis LST EN 12620:2003+A1:2008 standarto reikalavimus. Gamintojo deklaruojami žvirgždo fizikinių savybių rodikliai bei granuliometrinè sudètis pateikta 2.5 lentelèje ir 2.2 paveiksle.

Žvirgždo mineralinè-petrografinè sudètis: granitas - 29,4\%, dioritas $2,3 \%$, gabras $-2,0 \%$, porfyritas - $1,9 \%$, kvarcas - 3,0 \%, lauko špatai $1,2 \%$, pilkasis smiltainis $-1,5 \%$, klintis $-32,7 \%$, dolomitas $-26,0 \%$.

2.5 lentelè. Žvirgždo frakcija 4/16 fizikinių ir mechaninių savybių rodikliai

Table 2.5. The data of gravels fraction $4 / 16$ physical and mechanical properties

\begin{tabular}{|c|c|c|}
\hline Charakteristika & Frakcija & Vidutinè vertė \\
\hline Dalelių tankis, $\mathrm{kg} / \mathrm{m}^{3}$ & $4 / 16$ & 2670 \\
\hline Vandens imirkis, $\%$ & $4 / 16$ & 1,30 \\
\hline Piltinis tankis, $\mathrm{kg} / \mathrm{m}^{3}$ & $4 / 16$ & 1597 \\
\hline Atsparumas trupinimui, \% & $10 / 14$ & 19 \\
\hline
\end{tabular}

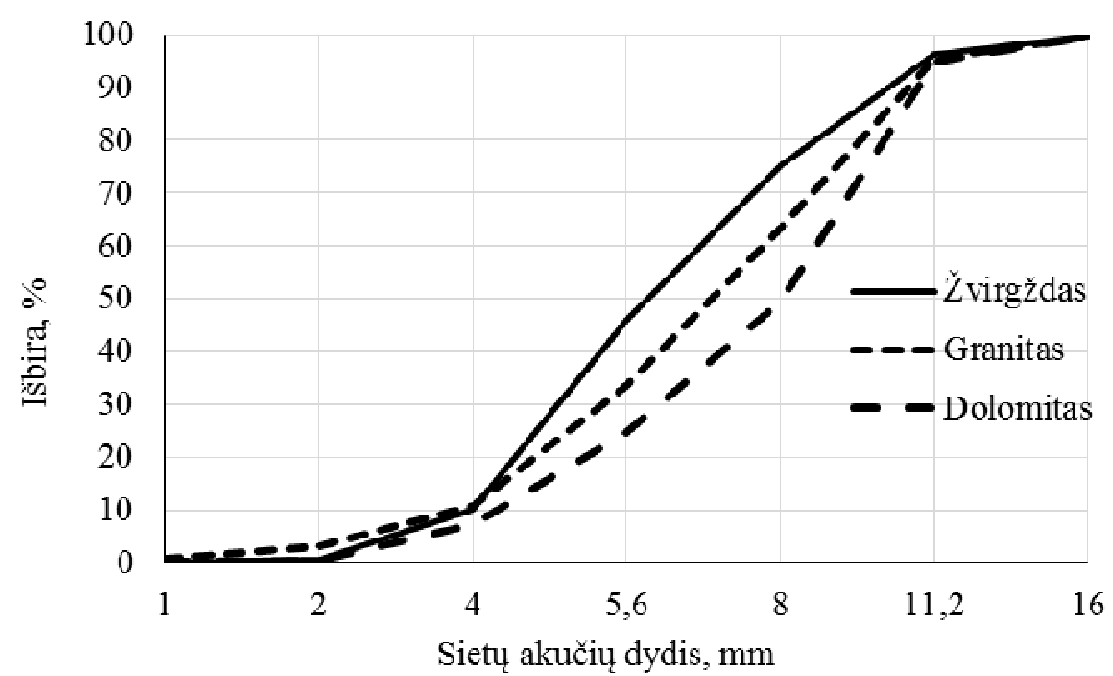

2.2 pav. Žvirgždo, granito skaldos, dolomito skaldos granuliometrinè sudetis

Fig. 2.2. The granulometric composition of gravel, crushed granite and crushed dolomite 
Granitinè skalda iš UAB „Granitinè skalda“, Granito g. 2, Vilnius. Frakcija 4/16. Gamintojo deklaruojami granitinès skaldos fizikinių ir mechaninių savybių rodikliai pateikti 2.6 lenteleje, granuliometrinè sudètis 2.2 paveiksle.

Granito mineralinè-petrografinè sudètis: kvarcas - 23,4\%, feldšpatai $54,7 \%$ (pilkieji plagioklazai $45 \%$ ir kalio feldšpatai $55 \%$ ), biotitas $-21,9 \%$.

2.6 lentelè. Granitinès skaldos frakcija 4/16 fizikinių ir mechaninių savybių rodikliai Table 2.6. The data of granite rubble fraction $4 / 16$ physical and mechanical properties

\begin{tabular}{|c|c|c|}
\hline Charakteristika & Frakcija & Vidutinè verte \\
\hline Dalelių tankis, $\mathrm{kg} / \mathrm{m}^{3}$ & $4 / 16$ & 2667 \\
\hline Vandens imirkis, $\%$ & $4 / 16$ & 1,37 \\
\hline Piltinis tankis, $\mathrm{kg} / \mathrm{m}^{3}$ & $4 / 16$ & 1440 \\
\hline Atsparumas trupinimui, \% & $10 / 14$ & 20 \\
\hline
\end{tabular}

Dolomitinè skalda iš UAB „Dolomitas“, Dolomito g. 6, Petrašiūnų k., Pakruojo r. frakcija 4/16. Gamintojo deklaruojami dolomitinès skaldos fizikiniai ir mechaniniai savybių rodikliai pateikti 2.7 lenteleje, granuliometrinè sudètis 2.2 paveiksle.

Dolomito mineralinè-petrografinè sudètis: dolomitas - 98,6 \%, molis/mergelis $-1,4 \%$.

2.7 lentelè. Dolomitinès skaldos frakcija 4/16 fizikinių ir mechaninių savybių rodikliai Table 2.7. The data of dolomite rubble fraction $4 / 16$ physical and mechanical properties

\begin{tabular}{|c|c|c|}
\hline Charakteristika & Frakcija & Vidutinè vertè \\
\hline Dalelių tankis, $\mathrm{kg} / \mathrm{m}^{3}$ & $4 / 16$ & 2771 \\
\hline Vandens ịmirkis, $\%$ & $4 / 16$ & 1,7 \\
\hline Piltinis tankis, $\mathrm{kg} / \mathrm{m}^{3}$ & $4 / 16$ & 1530 \\
\hline Atsparumas trupinimui, \% & $4 / 16$ & 20 \\
\hline
\end{tabular}

Keramzito žvyro frakcijos 4/8 ir 8/16 iš AB „Palemono keramika“, Pamario g. 1, Kaunas. Gamintojo deklaruojami rodikliai: fr. 4/8 piltinis tankis 500 $600 \mathrm{~kg} / \mathrm{m}^{3}$, daleliu tankis $2155 \mathrm{~kg} / \mathrm{m}^{3}$, vandens igertis iki $20 \%$; fr. $8 / 16$ piltinis tankis $500-600 \mathrm{~kg} / \mathrm{m}^{3}$, daleliu tankis $2185 \mathrm{~kg} / \mathrm{m}^{3}$, vandens igertis iki $15 \%$. Keramzito žvyro granuliometrinè sudètis, pateikta 2.3 ir 2.4 paveiksluose.

Keramzito mineralinę sudèti sudaro kristaliniai aliumosilikatai tokie kaip silimanitas $\left(\mathrm{Al}_{2} \mathrm{O}_{3} \cdot \mathrm{SiO}_{2}\right)$, mulitas $\left(3 \mathrm{Al}_{2} \mathrm{O}_{3} \cdot 2 \mathrm{SiO}_{2}\right)$, plagioklazai $\left(\mathrm{NaAlSi}_{3} \mathrm{O}_{8}\right.$ (albitas) iki $\mathrm{CaAl}_{2} \mathrm{Si}_{2} \mathrm{O}_{8}$ (anortito)) ir kiti. 


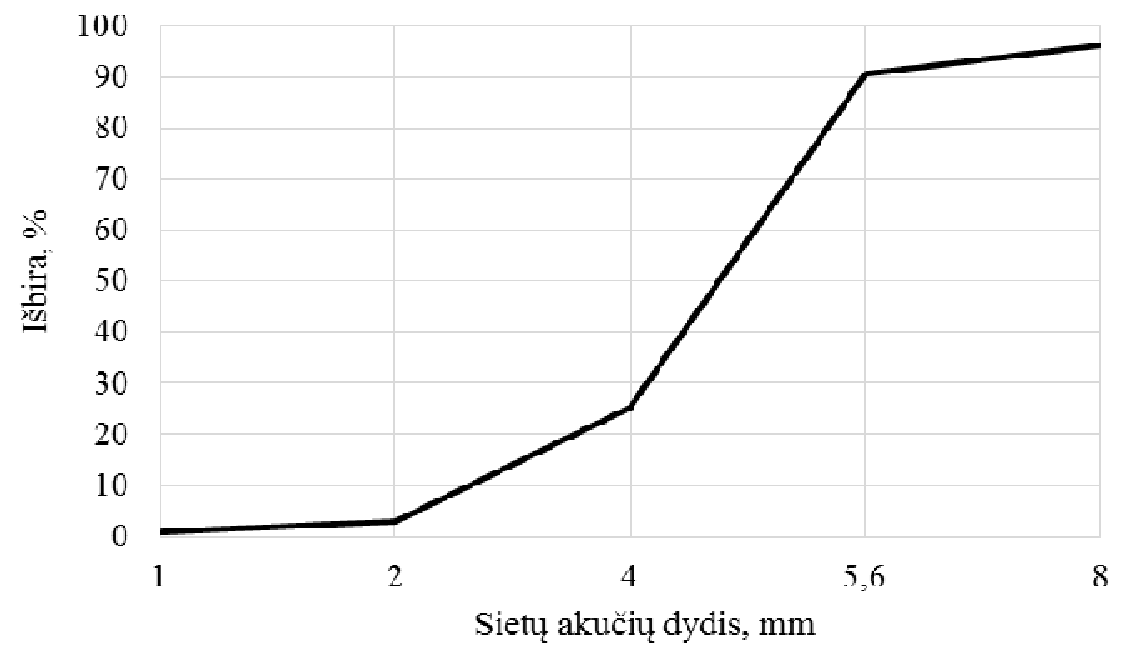

2.3 pav. Keramzito žvyro (frakcija 4/8) granuliometrinè sudètis

Fig. 2.3. The granulometric composition of expanded clay aggregate (fraction 4/8)

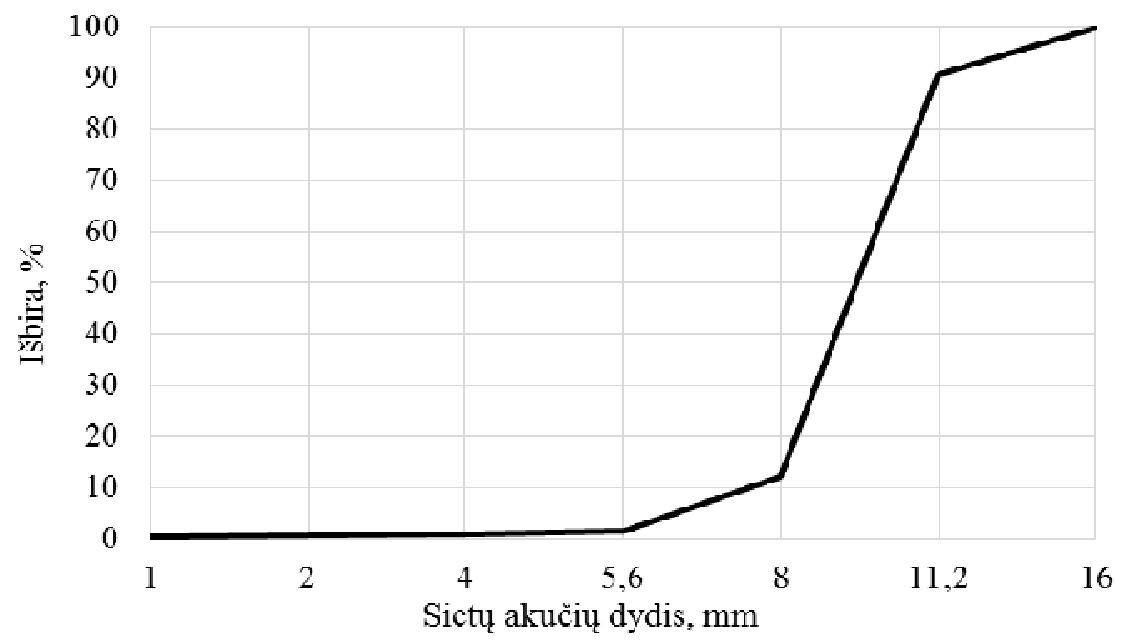

2.4 pav. Keramzito žvyro (frakcija 8/16) granuliometrinè sudètis

Fig. 2.4. The granulometric composition of expanded clay aggregate (fraction $8 / 16)$

Superplastiklis „Dynamon Xtend“, sudarytas iš modifikuotų akrilinių polimeru, galima įmaiša $0,3-2,0 \%$ pagal cemento masę, tankis $1,06 \mathrm{~g} / \mathrm{cm}^{3}, \mathrm{pH}-$ 6,5 , gamintojas Mapei, Norvegija.

Orą itraukianti įmaiša „Rebalit LP“, galima įmaiša $0,2-0,6 \%$ pagal cemento masę, tankis $-1,01 \mathrm{~g} / \mathrm{cm}^{3}$, pH $10 \pm 1$, gamintojas Remei Baltica OÜ, Estija. 


\subsection{Betono bandinių formavimas ir kietinimas}

Išbandytos betono sudètys pateikiamos 2.8-2.10 lentelèse. Betono stiprumo klasė C35/45, kuri tinkama laikančiosioms konstrukcijoms gaminti.

2.8 lentelejje pateikiama betono mišinių sudètys, kurios buvo naudojamos cemento priedu itakai tirti. Tyrimai atliekami su cementu be priedu, su smulkiai maltu cementu, su turinčiu $17 \%$ klinties priedo, su turinčiu $17 \%$ ir $70 \%$ šlako priedo. Vandens ir cemento santykis lygus 0,93 .

2.8 lentelè. Betono mišinio sudètys (medžiagų kiekiai $1 \mathrm{~m}^{3}$ ) cemente esančių mineraliniu priedu įtakai tirti

Table 2.8. The quantities of $1 \mathrm{~m}^{3}$ concrete mixtures for cement additives influence investigation

\begin{tabular}{|c|c|c|c|c|c|c|c|c|}
\hline \multirow{2}{*}{$\begin{array}{l}\text { Sudėties } \\
\text { žymuo }\end{array}$} & \multicolumn{5}{|c|}{ Cementas, kg } & \multirow{2}{*}{$\begin{array}{l}\text { Šamotas } \\
\text { fr. } 0 / 4, \\
\mathrm{~kg}\end{array}$} & \multirow{2}{*}{$\begin{array}{l}\text { Plas- } \\
\text { tiklis, } \\
\text { kg }\end{array}$} & \multirow{2}{*}{$\begin{array}{r}\text { Van } \\
\text { duo, } \\
\mathrm{kg}\end{array}$} \\
\hline & $\begin{array}{l}\text { CEM } \\
\text { I } 42,5 \\
\mathrm{~N}\end{array}$ & $\begin{array}{l}\text { CEM I } \\
42,5 \mathrm{R}\end{array}$ & $\begin{array}{c}\text { CEM } \\
\text { II/A- } \\
\mathrm{LL} \\
42,5 \mathrm{~N}\end{array}$ & $\begin{array}{c}\text { CEM } \\
\text { II/A-S } \\
42,5 \mathrm{~N}\end{array}$ & $\begin{array}{c}\text { CEM } \\
\text { III/B } \\
32,5 \mathrm{~N}- \\
\text { LH }\end{array}$ & & & \\
\hline $\begin{array}{l}\mathrm{C} 1 \mathrm{~N} \text { (be } \\
\text { priedų) }\end{array}$ & 323 & - & - & - & - & 1896 & 6,4 & 300 \\
\hline $\begin{array}{c}\mathrm{C} 1 \mathrm{R} \\
\text { (smul- } \\
\text { kiai } \\
\text { maltas) }\end{array}$ & - & 323 & - & - & - & 1896 & 6,4 & 300 \\
\hline $\begin{array}{l}\text { C2L (17 } \\
\% \text { klin- } \\
\text { ties } \\
\text { priedas) }\end{array}$ & - & - & 323 & - & - & 1896 & 6,4 & 300 \\
\hline $\begin{array}{l}\text { C2S (17 } \\
\% \text { šlako } \\
\text { priedas) }\end{array}$ & - & - & - & 323 & - & 1896 & 6,4 & 300 \\
\hline $\begin{array}{l}\text { C3 (70 } \\
\% \text { šlako } \\
\text { priedas) }\end{array}$ & - & - & - & - & 323 & 1896 & 6,4 & 300 \\
\hline
\end{tabular}

2.9 lenteleje pateikiama betono mišinio sudètis ir kiekiai, kurie buvo naudoti užpildo įtakai tirti. Tyrimai atlikti su žvirgždu, dolomito skalda, granito skalda ir keramzito užpildais. 
2.9 lentelè. Betono mišinio sudètys (medžiagų kiekiai $1 \mathrm{~m}^{3}$ ) užpildo įtakai tirti Table 2.9. The quantities of $1 \mathrm{~m}^{3}$ concrete mixtures for aggregate influence investigation

\begin{tabular}{|c|c|c|c|c|c|c|c|c|c|c|}
\hline \multirow[t]{3}{*}{$\begin{array}{c}\text { Sudèties } \\
\text { žymuo }\end{array}$} & \multicolumn{2}{|c|}{$\begin{array}{c}\text { Cementas, } \\
\text { kg }\end{array}$} & \multicolumn{6}{|c|}{ Užpildas, kg } & \multirow{3}{*}{ 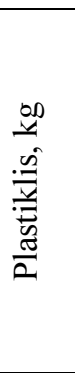 } & \multirow{3}{*}{ 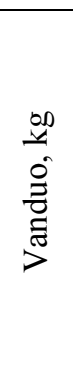 } \\
\hline & \multirow{2}{*}{\begin{tabular}{l}
$z$ \\
$n$ \\
$i$ \\
\multirow{I}{J}{} \\
$\sum_{\mathbb{I}}$
\end{tabular}} & \multirow{2}{*}{ 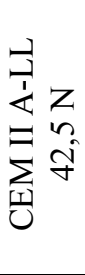 } & \multirow[t]{2}{*}{ 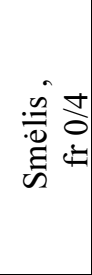 } & \multirow{2}{*}{ 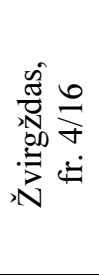 } & \multirow{2}{*}{ 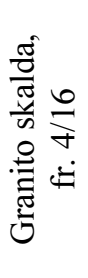 } & \multirow{2}{*}{ 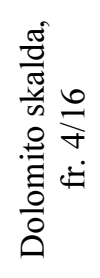 } & \multicolumn{2}{|c|}{ 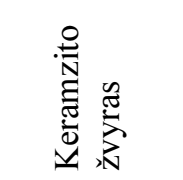 } & & \\
\hline & & & & & & & $\begin{array}{l}\text { fr. } \\
4 / 8\end{array}$ & $\begin{array}{c}\text { fr. } \\
8 / 16\end{array}$ & & \\
\hline $\begin{array}{c}\text { U1Ž } \\
\text { (žvirgž- } \\
\text { das) }\end{array}$ & 331 & - & 856 & 1020 & - & - & - & - & 3,31 & 149 \\
\hline $\begin{array}{l}\text { U1G } \\
\text { (grani- } \\
\text { tas) }\end{array}$ & 331 & - & 856 & - & 1020 & - & - & - & 3,31 & 149 \\
\hline $\begin{array}{l}\text { U1D } \\
\text { (dolomi- } \\
\text { tas) }\end{array}$ & 331 & - & 856 & - & - & 1020 & - & - & 3,31 & 149 \\
\hline $\begin{array}{c}\text { U1K } \\
\text { (keramz- } \\
\text { itas) }\end{array}$ & 331 & - & 856 & - & - & - & 92 & 112 & 3,31 & 149 \\
\hline $\begin{array}{c}\text { U2Ž } \\
\text { (žvirgž- } \\
\text { das) }\end{array}$ & - & 331 & 856 & 1020 & - & - & - & - & 3,31 & 149 \\
\hline $\begin{array}{l}\mathrm{U} 2 \mathrm{G} \\
\text { (grani- } \\
\text { tas) }\end{array}$ & - & 331 & 856 & - & 1020 & - & - & - & 3,31 & 149 \\
\hline $\begin{array}{l}\text { U2D } \\
\text { (dolomi- } \\
\text { tas) }\end{array}$ & - & 331 & 856 & - & - & 1020 & - & - & 3,31 & 149 \\
\hline $\begin{array}{c}\mathrm{U} 2 \mathrm{~K} \\
\text { (keramz- } \\
\text { itas) }\end{array}$ & - & 331 & 856 & - & - & - & 92 & 112 & 3,31 & 149 \\
\hline
\end{tabular}

2.10 lentelejje pateikiama betono mišinio sudetis ir kiekiai, kurie buvo naudoti itraukto oro kiekio ịtakai tirti. Tyrimai atlikti su skirtingomis septyniomis sudètimis. Pirmos penkios sudètys sumaišytos su $0,1 \%, 0,2 \%, 0,3 \%, 0,6 \%$ ir be orą įtraukiančios įmaišos. Gautas oro kiekis betono mišinyje be oro itraukiančios i̇maišos $3,2 \%$, su $0,1 \%$ orą įtraukiančia įmaiša $4,0 \%$, su $0,2 \%$ orą įtraukiančia įmaiša $5,0 \%$, su $0,3 \%$ orą įtraukiančia įmaiša $10,0 \%$, su $0,6 \%$ 
orą įtraukiančia įmaiša 14,0 \%. Norint gauti betoną su vienodu gniuždymo stipriu buvo padidintas cemento kiekis. Padidinus cemento kiekį ir įdejjus $0,3 \%$ orą ịtraukiančios įmaišos, gautas oro kiekis betone yra $8,5 \%$, su $0,6 \%$ gautas oro kiekis siekė $12,0 \%$.

2.10 lentelè. Betono mišinio sudètys (medžiagų kiekiai $1 \mathrm{~m}^{3}$ ) įtraukto oro kiekio įtakai tirti

Table 2.10. The quantities of $1 \mathrm{~m}^{3}$ concrete mixtures for amount of air influence investigation

\begin{tabular}{|c|c|c|c|c|c|c|}
\hline \multirow[t]{2}{*}{ Sudèties žymuo } & \multirow{2}{*}{$\begin{array}{c}\begin{array}{c}\text { Cemen- } \\
\text { tas, kg }\end{array} \\
\text { CEM II } \\
\text { A-LL }\end{array}$} & \multicolumn{2}{|c|}{ Užpildas, kg } & \multirow{2}{*}{$\begin{array}{c}\text { Plas- } \\
\text { tiklis, } \\
\mathrm{kg}\end{array}$} & \multirow{2}{*}{$\begin{array}{c}\text { Orą } \\
\text { ịtrau- } \\
\text { kianti } \\
\text { imaiša, } \\
\%\end{array}$} & \multirow{2}{*}{$\begin{array}{l}\text { Vanduo, } \\
\mathrm{kg}\end{array}$} \\
\hline & & $\begin{array}{l}\text { Smèlis, } \\
\text { fr. } 0 / 4\end{array}$ & $\begin{array}{c}\text { Dolomito } \\
\text { skalda } \\
\text { fr. } 4 / 16\end{array}$ & & & \\
\hline $\begin{array}{c}\text { O (itraukto oro } \\
3,2 \%)\end{array}$ & 331 & 856 & 1020 & 3,31 & 0 & 149 \\
\hline $\begin{array}{c}\text { O-01 (itraukto } \\
\text { oro } 4,0 \% \text { ) }\end{array}$ & 331 & 856 & 1020 & 3,31 & 0,1 & 149 \\
\hline $\begin{array}{c}\text { O-02 (itraukto } \\
\text { oro } 5,0 \% \text { ) }\end{array}$ & 331 & 856 & 1020 & 3,31 & 0,2 & 149 \\
\hline $\begin{array}{c}\text { O-03 (itraukto } \\
\text { oro } 10,0 \% \text { ) }\end{array}$ & 331 & 856 & 1020 & 3,31 & 0,3 & 149 \\
\hline $\begin{array}{c}\text { O-06 (itraukto } \\
\text { oro } 14,0 \% \text { ) }\end{array}$ & 331 & 856 & 1020 & 3,31 & 0,6 & 149 \\
\hline $\begin{array}{l}\mathrm{O}-03 \mathrm{P} \text { (itraukto } \\
\text { oro } 8,5 \% \text { ) }\end{array}$ & 460 & 856 & 1020 & 4,6 & 0,3 & 149 \\
\hline $\begin{array}{c}\text { O-06P (itraukto } \\
\text { oro } 12,0 \% \text { ) }\end{array}$ & 520 & 856 & 1020 & 5,2 & 0,6 & 149 \\
\hline
\end{tabular}

Eksperimentams buvo formuojami betono kubeliai, kurių matmenys $100 \mathrm{~mm} \times 100 \mathrm{~mm} \times 100 \mathrm{~mm}$. Betono mišinio slankumas buvo nustatytas pagal standartą LST EN 12350-2, tankis - pagal LST EN 12350-6, oro kiekis mišinyje naudojant slègini metodą pagal - LST EN 12350-7. Betono kubeliai prieš bandymus buvo išlaikomi 28 paras vandenyje, kurio temperatūra $20 \pm$ $2{ }^{\circ} \mathrm{C}$. Kiekvienos partijos bandinių buvo pagaminta po $12 \mathrm{vnt}$. Po tris bandinius buvo paimta gniuždymo stipriui nustatyti po 28 parų. Betono bandinių gniuždymo stipris nustatytas pagal - LST EN 12390-3:2009. Tankis nustatytas remiantis standarto LST EN 12390-7:2009 reikalavimais. 


\subsection{Vienpusis atsparumo ugniai bandymo metodas}

Vienpusio atsparumo ugniai bandymo metodui naudoti suformuoti skirtingu mišinių betono kubeliai, kurių matmenys $(100 \times 100 \times 100) \mathrm{mm}$. Keturios kubelio briaunos buvo izoliuotos mineraline vata, kitos dvi neizoliuotos. Viena neizoliuota kubelio briauna buvo nukreipta ị krosnies vidų ir veikiama aukštos temperatūros pagal standartine gaisro kreivę. İrangos vaizdas ir bandinio nuotrauka iš veikiamos temperatūra pusès pateikta 2.5 paveiksle.

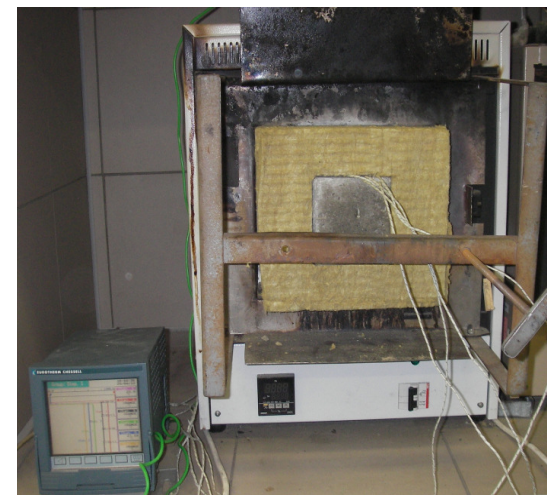

a)

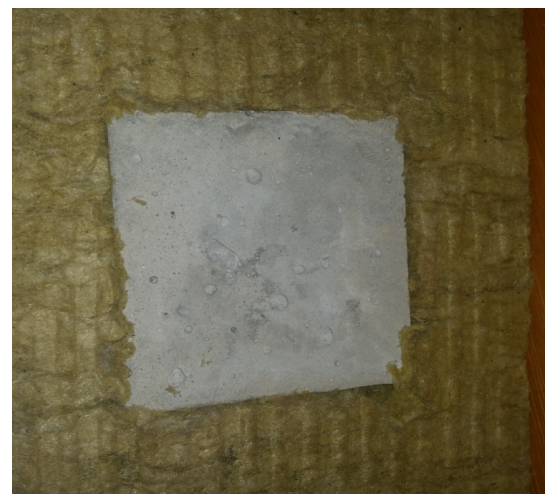

b)

2.5 pav. Bandymų ịrangos ir bandinio vaizdas: a) krosnelè su temperatūros registratoriumi; b) bandinys iš veikiamos temperatūra pusès

Fig. 2.5. Test equipment and sample image: a) oven with temperature recorder;

b) sample image from the exposed to temperature side

Vienpusio atsparumo ugniai kaitinimo kamera sudaryta iš plieninio karkaso, ant kurio iš $2 \mathrm{~mm}$ storio nerūdijančio plieno lakštų suformuota $(200 \times 200 \times 50) \mathrm{mm}$ dydžio kaitinimo kamera. Iš vienos pusès kaitinimo kamera izoliuota aukštoms temperatūroms atsparia šiltinamaja izoliacija. Kaitinimo kamerai šildyti buvo naudojami 8 vnt. 32A13/0,7T220 tipo vamzdiniai elektriniai kaitinimo elementai, kurių kiekvieno galingumas buvo $0,7 \mathrm{~kW}$, skersmuo $13 \mathrm{~mm}$, o ilgis - $200 \mathrm{~mm}$. Visi kaitinimo elementai sujungti lygiagrečiai. Eksperimento principas - kaitinti bandinị iš vienos pusès, kaip numatyta standarte LST EN 1363-1:2012 pagal reglamentuotą temperatūros-laiko priklausomybę. Temperatūros kilimas krosnyje turi atitikti šią priklausomybę:

$$
T-T_{o}=345 \lg _{10}(8 t+1),
$$

čia $t$ - laikas, min; $T$ - krosnies temperatūra, pasiekta per laiką $t,{ }^{\circ} \mathrm{C} ; T_{0}-$ pradinè krosnies temperatūra, ${ }^{\circ} \mathrm{C}$. 


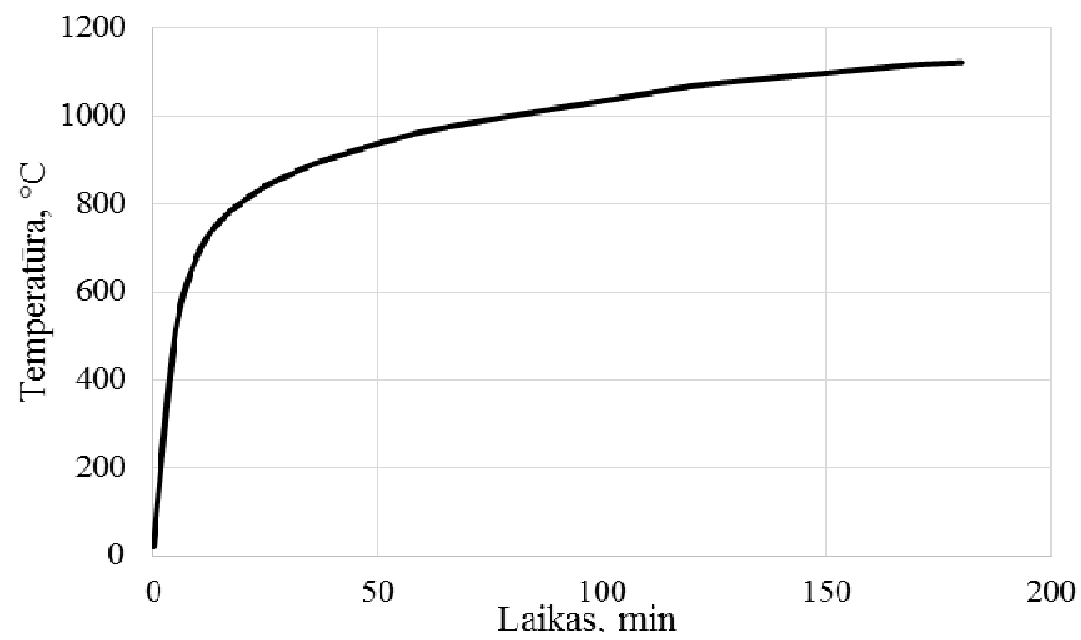

2.6 pav. Standartinè gaisro kreivè (ISO 834)

Fig. 2.6. Standard fire curve (ISO 834)

Bandymui atlikti anksčiau aprašyta įranga užtikrino pasirinktą šiluminį režimą. Keliamos temperatūros svyravimo ribos siekè $1-16^{\circ} \mathrm{C}$. Be abejo, temperatūros pasiskirstymui konstrukcijos skerspjūvyje turi įtakos ir konstrukcijos paviršiui tenkantis šiluminis poveikis bei šio poveikio kaita priklausomai nuo kaitinimo režimo.

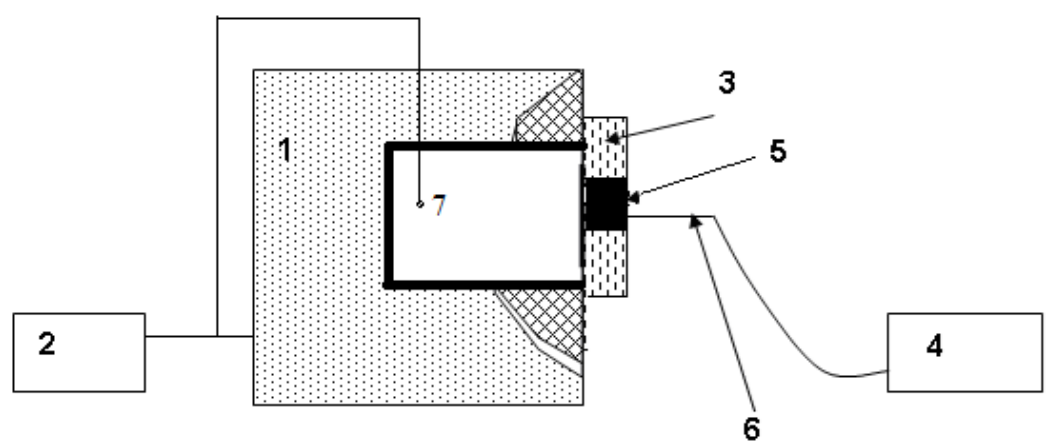

2.7 pav. Vienpusio atsparumo ugniai bandymo metodo principinè schema:

1 - elektrinè krosnelè; 2 - elektrinès krosnelès valdymo blokas; 3 -bandinio laikiklis su mineralinès vatos izoliacija; 4 - temperatūros registravimo prietaisas; 5 - bandinys; 6 - matavimo termoporos K tipo, 7 - elektrinès krosnelès termopora

Fig. 2.7. The principal scheme of the one-side heating equipment that has been used for one side heating tests: 1 - electric oven; 2 - electric oven heating control unit; 3 sample storage device with mineral wool insulating; 4 - temperature recorder; 5 specimen, 6 - measuring thermocouple K type, 7 - thermocouple of electric oven 
Šiluminis režimas buvo reglamentuojamas standartinio gaisro temperatūros, kuri imituoja išsiplètusio gaisro stadiją (post - flashover), priklausomybe nuo laiko (2.6 pav.). Naudojantis minètaja priklausomybe, konstrukcijų atsparumo ugniai bandymai atliekami įvairiose pasaulio šalyse.

Skirtinga temperatūros kaitos sparta kaitinimo kameroje svarbi keliais aspektais. Greitai pasiekta aukšta temperatūra imituoja pačias nepalankiausias tiriamajai medžiagai, kai joje prasideda nepertraukiamas šilumos sklidimo procesas, aplinkos sąlygas, darantis įtaką fizikiniams-cheminiams virsmams tiriamojoje medžiagoje.

Naudojant minètą įrangą betono bandiniai buvo kaitinami tam tikrą iš anksto numatytą laiko tarpą t, $180 \mathrm{~min}$. Po šio laiko bandinys buvo ištraukiamas iš kameros ir atvėsinamas aplinkos sąlygose: temperatūra $23 \pm 3{ }^{\circ} \mathrm{C}$, santykinè drègmé $50 \pm 10 \%$.

Temperatūros pasiskirstymui įvairiuose betono sluoksniuose matuoti, buvo pasitelktos penkios K tipo termoporos. Jos įdedamos i betono kubeli, prieš tai išgręžus $3 \mathrm{~mm}$ skersmens kiaurymes i $5 \mathrm{~cm}$ bandinio gylį. Iš viso gręžiamos 5 kiaurymès $1 \mathrm{~cm}$ atstumu viena nuo kitos iš kaitinamos plokštumos. Bandinio su termoporomis vaizdas pateiktas 2.8 paveiksle.

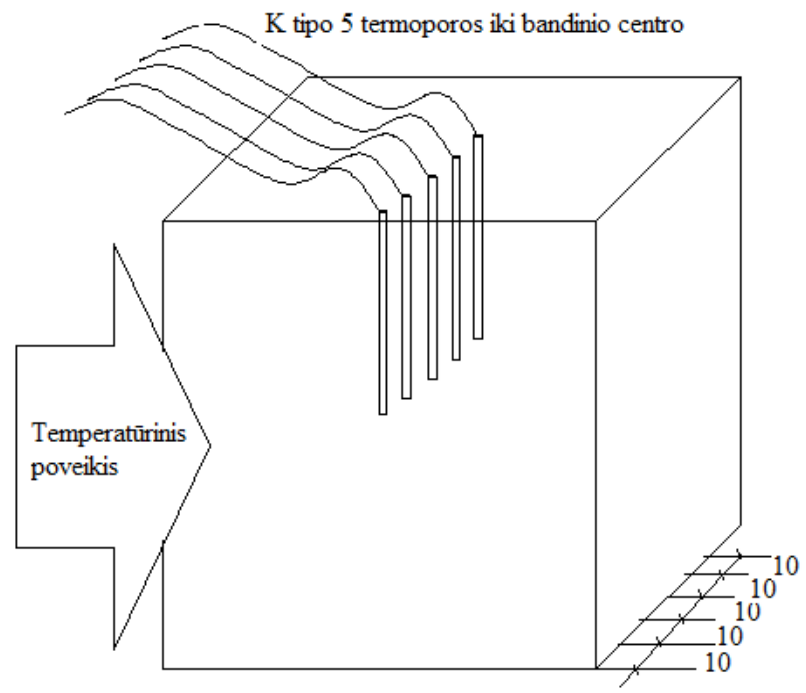

2.8 pav. Vienpusio atsparumo ugniai bandinio su termoporomis vaizdas

Fig. 2.8. One-side heating specimen with termocouples view

Betono savybių pokyčių vertinimas atliktas pagal 2.5 poskyryje aprašytas metodikas. 


\subsection{Tūrinis atsparumo ugniai bandymo metodas}

Tūrinio atsparumo ugniai bandymo metodui naudoti suformuoti skirtingų mišinių betono kubeliai, kurių matmenys $100 \mathrm{~mm} \times 100 \mathrm{~mm} \times 100 \mathrm{~mm}$. Kubelis buvo padedamas ant kaolino vatos $30 \mathrm{~mm}$ storio sluoksnio, taip viena kubelio briauna buvo izoliuota nuo temperatūrinio poveikio, kitos penkios neizoliuotos, t. y. užtikrintas laisvas šilumos pritekejjimas iš visų pusių. Bandymo metodo principinè schema pateikta 2.9 paveiksle.

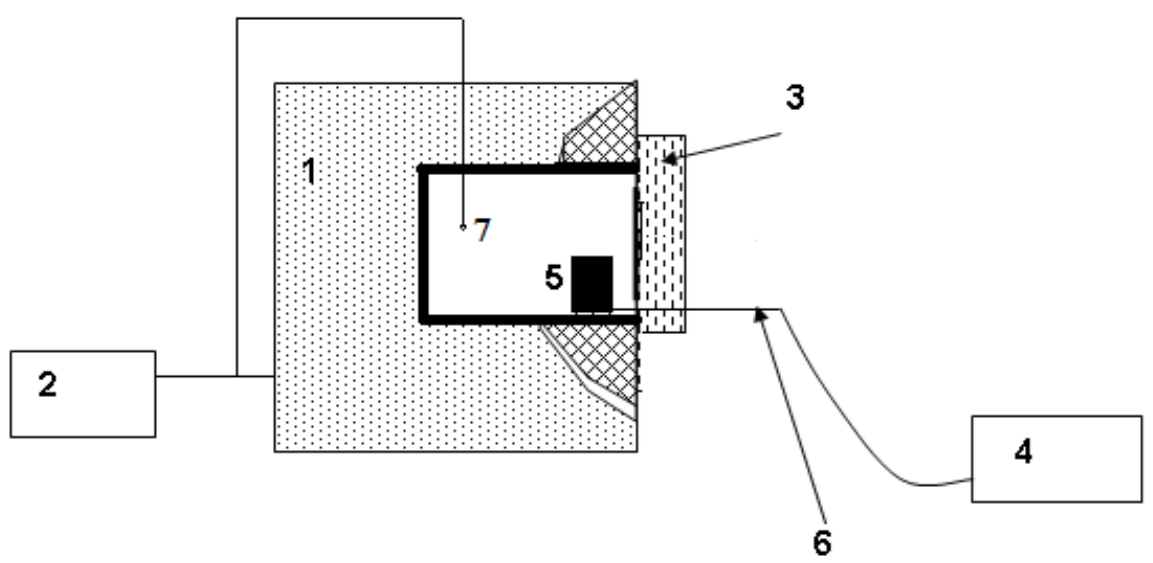

2.9 pav. Tūrinio atsparumo ugniai bandymo metodo principinè schema:

1 - kaitinimo krosnis; 2 - kaitinimo krosnies valdymo blokas; 3 - kameros durys; 4 - temperatūros registravimo prietaisas; 5 - bandinys; 6 - matavimo termoporos $\mathrm{K}$ tipo, 7 - krosnies termopora

Fig. 2.9. The principal scheme of the volumetric heating equipment that has been used

for volumetric heating tests: 1 - oven; 2 - oven heating control unit; 3 - door of chamber; 4 -temperature recorder; 5 - specimen, 6 - measuring thermocouple $\mathrm{K}$ type, 7 - thermocouple of oven

Tūriniai bandymai atliekami su Hasle firmos vertikalia konstrukcijų $3,4 \mathrm{~m} \times 3,4 \mathrm{~m} \times 1,5 \mathrm{~m}$ (aukštis $\times$ plotis $\times$ gylis) atsparumo ugniai bandymų krosnimi, kuri atitinka bandymo standarto LST EN 1363-1:2012 keliamus reikalavimus. Bandymų krosnies vaizdas pateikiamas paveiksle 2.10.

Eksperimento principas - kaitinti bandini iš visu pusių, kaip numatyta standarte LST EN 1363-1:2012 pagal reglamentuotą temperatūros-laiko priklausomybę. Temperatūros priklausomybè pateikta 2.1 formulèje, temperatūros kilimo grafikas 2.6 paveiksle, principinè schema 2.9 paveiksle. Naudojant minètą įrangą betono bandiniai buvo kaitinami tam tikrą iš anksto numatytą laiko tarpą t, 180 min. Po šio laiko bandinys buvo ištraukiamas iš kameros ir atvèsinamas aplinkos sąlygose: temperatūra $23 \pm 3{ }^{\circ} \mathrm{C}$, santykinè drègmè $50 \pm 10 \%$. 


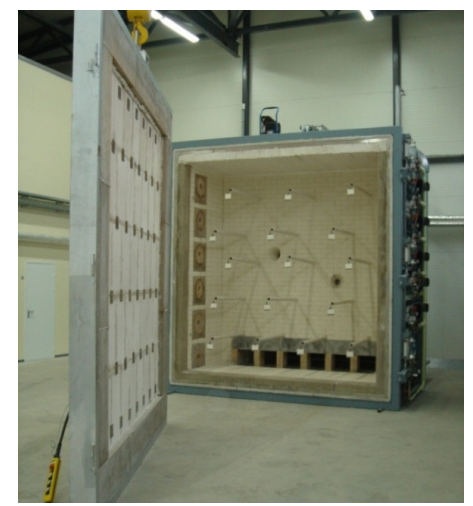

2.10 pav. Tūrinio kaitinimo bandymų ịangos bendras vaizdas

Fig. 2.10. The overall view of volumetrical heating testing equipment

Temperatūros pasiskirstymui betono įvairiuose sluoksniuose matuoti, buvo pasitelktos penkios K tipo termoporos. Jos įdedamos i betono kubelį, prieš tai išgręžus $3 \mathrm{~mm}$ skersmens kiaurymes i $5 \mathrm{~cm}$ bandinio gyli. Iš viso gręžiamos 5 kiaurymès $1 \mathrm{~cm}$ atstumu viena nuo kitos pradedant nuo bandinio krašto. Bandinio su termoporomis vaizdas pateiktas 2.11 paveiksle.

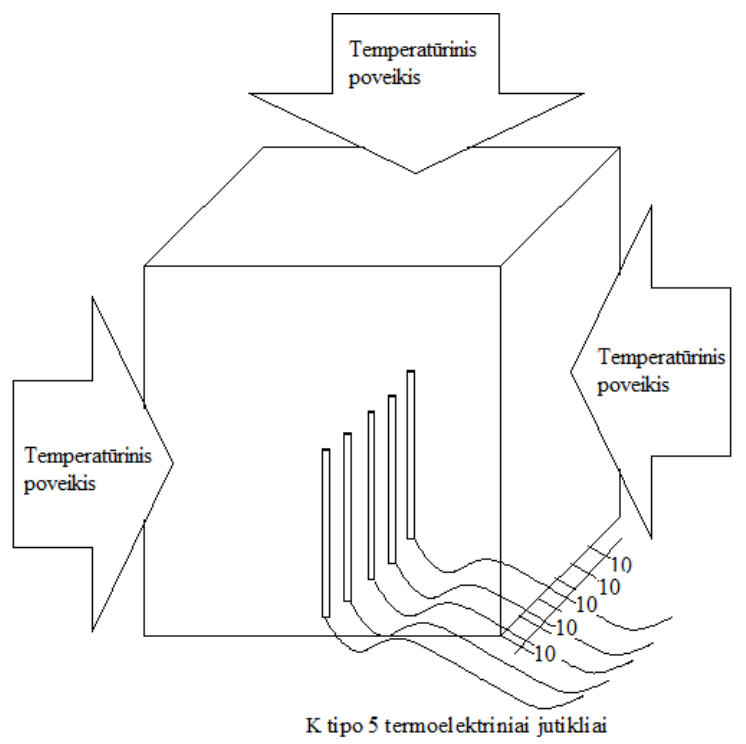

2.11 pav. Tūrinio atsparumo ugniai bandinio su termoporomis vaizdas

Fig. 2.11. Volumetrical heating specimen with termocouples view

Betono savybių pokyčių vertinimas atliktas pagal 2.5 poskyryje aprašytas metodikas. 


\subsection{Cementinio akmens ir betono savybių vertinimas}

\subsubsection{Cementinio akmens ir užpildų termogravimetrinė ir infraraudonūjų spindulių spektroskopijos analizè}

Terminius efektus kaitinamoje medžiagoje sukelia fizikiniai ir cheminiai procesai. Dèl šių efektų dažnai kinta tiriamosios medžiagos masè. Todèl, atliekant termografinę analizę, šiuolaikiniuose prietaisuose kartu registruojami ir masès pokyčiai. Šie duomenys naudojami tiriamujų medžiagų kiekybinei analizei.

Termogravimetrijos metu registruojama masès kitimo kreivè (vadinamoji gravimetrijos kreivè - TG) ir masès pokyčių $\Delta \mathrm{m} / \Delta \mathrm{T}$ kreivè (ji gaunama derivatografu ir vadinama derivacine terminès gravimetrijos kreive - DTG) (Šiaučiūnas et al. 2007).

Termografinè analizè atlikta naudojant termogravimetrini analizatoriu „TA instrument". Temperatūra matuota $\mathrm{K}$ tipo termopora, naudoti platinos tigliai. Analizè atlikta temperatūrų intervale nuo $25^{\circ} \mathrm{C}$ iki $1000{ }^{\circ} \mathrm{C}$. Temperatūros kèlimo greitis $10^{\circ} \mathrm{C} / \mathrm{min}$. Pasirinkta inertinè azoto aplinka.

Cementinio akmens paruošimas termogravimetriniams tyrimams:

1. Sumaišomi skirtingi cementai su vandeniu tuo pačiu santykiu ir pagaminamos prizmelès, matmenys $(40 \times 40 \times 160) \mathrm{mm}$.

2. Prizmelès vieną dieną kietinamos laboratorijos aplinkoje ir 28 dienas vandenyje $20^{\circ} \mathrm{C}$ temperatūroje, kiti bandiniai po kietinimo vandenyje buvo išlaikomi kondicionavimo patalpoje pusantrų metų, patalpos sąlygos: $23 \pm 2{ }^{\circ} \mathrm{C}$ temperatūra ir $50 \pm 5 \%$ santykinè drègmè.

3. Po kietinimo (28 parų arba 1,5 metų) iš prizmelès vidurio yra paimama cementinio akmens dalis, kuri sutrupinama ir sijojama, naudojant $0,8 \mathrm{~mm}$ akučių dydžio sietą.

4. Gavus hidratuoto cemento miltelius yra sustabdoma cementinio akmens hidratacija, panaudojant acetoną.

Užpildo termogravimetriniai tyrimai atliekami su skirtingais užpildais juos sutrupinus ir prasijojus per $0,8 \mathrm{~mm}$ akučių dydžio sietą.

Cementinio akmens infraraudonujų spindulių spektroskopiniai tyrimai atlikti su Mattson firmos infraraudonųjų spindulių spektrometru. Bandymai atliekami su skirtingais cementais, kurių hidratacija truko 28 paras ir 1,5 metų. Cemento milteliai paruošti pagal tą pačią technologiją kaip aprašyta 2.5.1 skyrelyje „cementinio akmens paruošimas termogravimetrijos tyrimams“ papildomai panaudojant kalio bromidą, kuris IR spindulių diapazone yra skaidrus (Šiaučiūnas et al. 2007).

Bandinių paruošimas infraraudonųjų spindulių spektroskopijos tyrimams:

1. $2 \mathrm{mg}$ tiriamos medžiagos sumaišoma su $200 \mathrm{mg}$ kalio bromidu ( $\mathrm{KBr})$. 
2. Mišinys suspaudžiamas presu ir gaunamas kelių šimtujų milimetro bandinys, kitaip vadinamas peletè.

\subsubsection{Betono savybių pokyčiai po kaitinimo}

Betono masès nuostoliai $\mathrm{M}$ apskaičiuojami po 3 val. kaitinimo temperatūriniu režimu pagal standartinę gaisro kreivę. Prieš kaitinant betono bandinys $(100 \mathrm{~mm} \times 100 \mathrm{~mm} \times 100 \mathrm{~mm})$ yra pasveriamas ir nustatoma pradinè mase $\mathrm{M}_{0}$. Po 3 val. kaitinimo bandinys ataušinamas aplinkos temperatūroje ir vèl pasveriamas, nustatoma $\mathrm{M}_{1}$. Masès nuostoliai apskaičiuojami pagal formulę:

$$
\mathrm{M}=\left(\left(\mathrm{M}_{0}-\mathrm{M}_{1}\right) / \mathrm{M}_{0}\right) \cdot 100 \%,
$$

čia $\mathrm{M}$ - masès nuostoliai, \%; $\mathrm{M}_{0}$ - pradinè bandinio masè, $\mathrm{g} ; \mathrm{M}_{1}-$ po 3 val. kaitinimo bandinio masè, $\mathrm{g}$

Ultragarso sklidimo greitis nustatomas betono bandinio po 28 paru kietinimo ir po 3 valandų kaitinimo vienpusiu atsparumo vertinimo metodu temperatūriniu režimu pagal standartinę gaisro kreivę. Ultragarso impulso sklidimo laikas nustatytas prietaisu „Pundit 7“ (keitiklių dažnis $54 \mathrm{kHz}$ ), apskaičiuotas ultragarso sklidimo greitis ( $\mathrm{V}_{\mathrm{UIG}}, \mathrm{m} / \mathrm{s}$ ) pagal formulę (Elzbutas 2007):

$$
\mathrm{V}_{\mathrm{UIG}}=1 / \mathrm{t} \text {, }
$$

čia 1 - bandinio ilgis, $\mathrm{m}$; $\mathrm{t}$ - signalo sklidimo laikas, $\mathrm{s}$

Betono gniuždymo stipris nustatomas po 28 parų kietinimo, kiekvienam sumaišytam betono mišiniui. Po temperatūrinio poveikio betono kubeliai gniuždomi praejjus ne daugiau kaip 24 valandoms. Gniuždymo stipris nustatomas hidrauliniu Alpha3-3000 S presu, gamintojas Form Test Seidner \& Co. $\mathrm{GmbH}$, apkrovos kèlimo greitis $0,6 \mathrm{MPa} / \mathrm{s}$.

\subsubsection{Betono dilatometrinè ir mikrostruktūros analizè}

Betono terminis išsiplètimas nustatomas naudojant dilatometrą „Linseis L76“, kaitinimo greitis $10^{\circ} \mathrm{C} / \mathrm{min}$. Analizè atlikta temperatūrų intervale nuo $25^{\circ} \mathrm{C}$ iki $1000{ }^{\circ} \mathrm{C}$. Bandiniu dydis $8 \mathrm{~mm} \times 8 \mathrm{~mm} \times 50 \mathrm{~mm}$, išpjauti iš $100 \mathrm{~mm} \times$ $100 \mathrm{~mm} \times 100 \mathrm{~mm}$ dydžio betono kubelio.

Sukietejusio betono su skirtingais oro kiekiais mikrostruktūra buvo tiriama naudojant SEM JEOL JSM-7600F skenuojančią elektroninę mikroskopiją (SEM). Elektroninès mikroskopijos parametrai: $10 \mathrm{kV}$ ir $20 \mathrm{kV}$ itampa, atstumas iki bandinio paviršiaus nuo 7 iki $10 \mathrm{~mm}$. Tyrimai atliekami iš atskelto be- 
tono bandinio. Tyrimui paimami bandiniai iš kaitintos betono pusès, iš bandinio centro ir iš neveiktos pusès. Skeltas betono paviršius buvo padengtas plonu aukso sluoksniu, vakuume garinant aukso elektrodą naudojant „QUORUM Q150R ES“ prietaisą. Vaizdas kuriamas registruojant antrinių elektronų signalą. Atliktas didinimas nuo 30 iki 15000 kartų.

\subsection{Tyrimų rezultatų statistinio apdorojimo metodika}

Regresinei analizei atlikti duomenys buvo grupuojami ir paruošiami programa „MS Excel“, o eksperimentiniams duomenims statistiškai apdoroti buvo naudojama kompiuterinè programa „STATISTICA 7“ (Sakalauskas 1998). Šia programa atlikta eksperimentinių duomenų regresinè analizè bei gautos regresinès kreivès patikimumo statistinè analizè. Regresinè analizè nustato statistinio ryšio pobūdị ir aprašo priklausomojo kintamojo vidutinių reikšmių priklausomybę nuo vieno ar kelių nepriklausomujų kintamųjų reikšmių matematine formule ir kartu padeda prognozuoti funkcijos reikšmes.

Buvo tikrinami įvairūs matematiniai modeliai: tiesinis $\left(y=b_{0}+b \cdot x\right)$, su lūžio tašku $\left(\mathrm{y}=\left(\mathrm{b}_{01}+\mathrm{b}_{11} \cdot \mathrm{x}_{1}+\ldots+\mathrm{b}_{\mathrm{ml}} \cdot \mathrm{x}_{\mathrm{m}}\right) \cdot\left(\mathrm{y} \leq \mathrm{b}_{\mathrm{n}}\right)+\left(\mathrm{b}_{02}+\mathrm{b}_{12} \cdot \mathrm{x}_{1}+\ldots+\right.\right.$ $\left.b_{\mathrm{m} 2} \cdot x_{m}\right) \cdot\left(y>b_{n}\right)$. Priklausomybei išreikšti buvo pasirenkama tokia funkcija, kuri tiksliausiai apibūdina duomenu pasiskirstymo pobūdị. Buvo apskaičiuoti regresinio modelio kokybès rodikliai: koreliacijos koeficientas $\mathrm{R}$ ir determinacijos koeficientas $\mathrm{R}^{2}$. Šie koeficientai pageidautini kuo artimesni vienetui (Čekanavičius, Murauskas 2004; Martinėnas 2004). Jeigu R koeficiento reikšmé yra tarp 0,90 ir 1 , tai tarp tiriamujų dydžių yra labai stiprus tarpusavio ryšys, kai $0,7<\mathrm{R}<0,89$, stiprus ryšys. Kai dydis yra tarp 0,69 ir 0,4 , jis yra vidutinio stiprumo, o kai mažiau nei 0,4 , priklausomybè tarp dydžiu silpna (Čekanavičius, Murauskas 2004; Martinènas 2004). Vidutinis standartinis nuokrypis $\mathrm{S}_{\mathrm{e}}$ išreiškiamas kvadratine šaknimi iš normuotos klaidų nuokrypio kvadratų sumos. Kuo apskaičiuotieji $\mathrm{S}_{\mathrm{e}}$ dydžiai mažesni, tuo mažesnis nuokrypis nuo regresinès kreivès (Čekanavičius, Murauskas 2004; Martinènas 2004).

\subsection{Antrojo skyriaus išvados}

1. Infraraudonujų spindulių spektroskopinè ir termogravimetrinè analizė leidžia ištirti cementinio akmens mineralinès sudèties pokyčius veikiant aukštai temperatūrai ir kiekybiškai įvertinti destrukcinius procesus vykstančius betone gaisro metu. 
2. Dilatometrinè analizė kiekybiškai parodo betono komponentų (užpildų, mineralinių priedų) kristalinès gardelès pokyčius aukštose temperatūrose ir destrukcinius procesus vykstančius betone.

3. Vienpusis ir tūrinis atsparumo ugniai bandymų metodai leidžia nustatyti temperatūrinių laukų bandinyje pasiskirstymą, kuriais remiantis galima tiksliai prognozuoti konstrukcijos skerspjūvio temperatūrą bet kuriame taške ir nustatyti betono atsparumą ugniai.

4. Aukštos temperatūros paveikto betono analizè naudojant elektroninę mikroskopiją leidžia užfiksuoti pakitusius cementinio akmens hidratacijos produktus pagal jų morfologiją. 


\section{Cemento tipo, užpildụ bei oro kiekio itaka betono irimo procesams veikiant aukštai temperatūrai}

Skyriuje pateikiami rezultatai, gauti atlikus temperatūros pasiskirstymo betono bandiniuose su skirtingais cementais, užpildais bei skirtingu ịtraukto oro kiekiu bandymus. Nagrinejjami masès nuostolių, ultragarso greičio sklidimo, deformaciniai, infraraudonujų spinduliu spektroskopiniai bei gniuždymo stiprio pokyčiai kaitinant betoną ar cementini akmeni iki $1000-1100{ }^{\circ} \mathrm{C}$ temperatūros. Taip pat pateikiami temperatūrinio režimo prognozavimo betone rezultatai gaisro metu.

Šio skyriaus medžiaga paskelbta trijuose straipsniuose (Jocius et al. 2013; Jocius et al. 2014; Jocius, Skripkiūnas 2016) ir pristatyta penkiose mokslinèse konferencijose. 


\subsection{Mineralinių priedų ịtaka betono atsparumui ugniai}

\subsubsection{Temperatūros pasiskirstymas betone su skirtingais cementais esant vienpusiam temperatūros poveikiui}

Norint ištirti cemento priedų itaką betono atsparumui ugniai, buvo atlikti temperatūros pasiskirstymo bandiniuose bandymai, naudojant vienpusę kaitinimo metodiką, pagal standartinę gaisro kreivę. Bandinys buvo kaitinamas 3 valandas. Tyrimams buvo parinkti penki skirtingi cementai: CEM I 42,5N (be priedu), CEM I 42,5R (be priedų, smulkiai maltas), CEM II/A-LL 42,5N (su $17 \%$ klinties priedu), CEM II/A-S 42,5 N (su $17 \%$ aukštakrosnių šlako priedu) ir CEM III/B 32,5 N-LH/SR (su $70 \%$ aukštakrosnių šlako priedu). Bandiniams formuoti, buvo pasirinktas inertinis užpildas šamotas frakcija $0 / 4$. Betono sudètys pateiktos 2.8 lentelèje. Su skirtingais cementais gautos betono perkaitimo kreivès pateikiamos 3.1-3.3 paveiksluose.

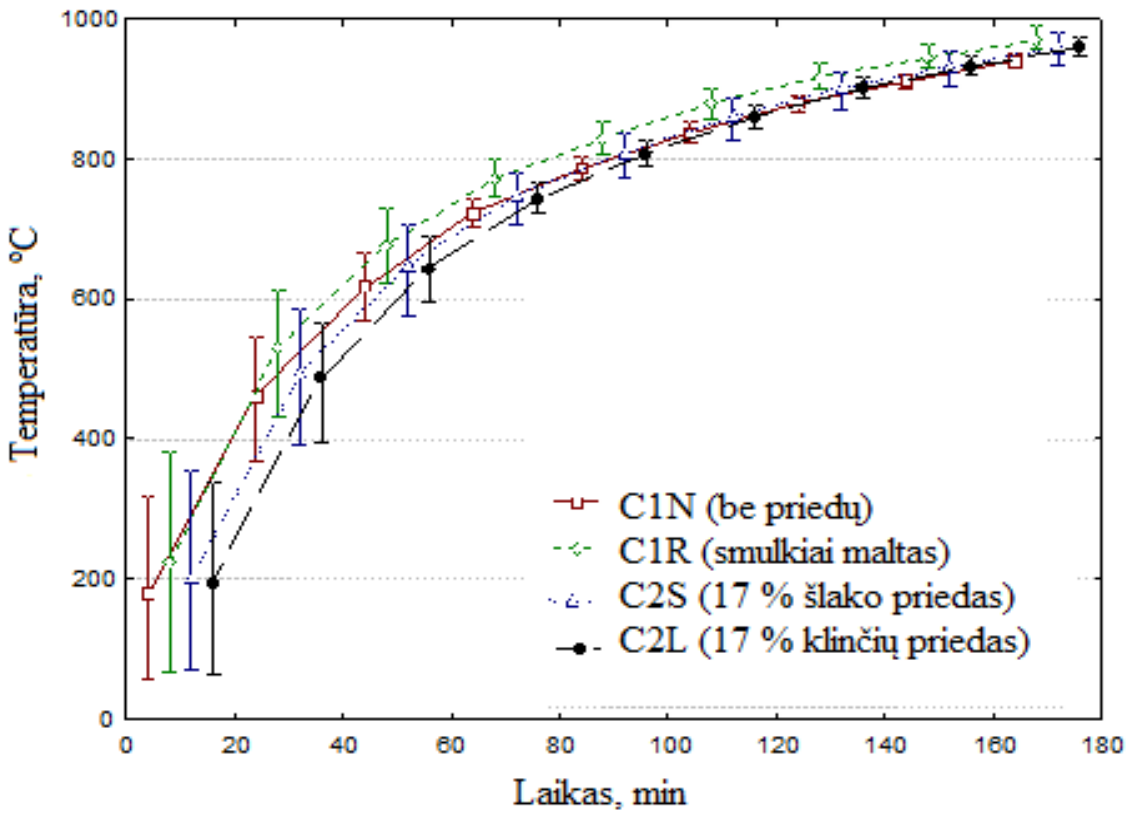

3.1 pav. Temperatūros pasiskirstymas betono bandiniuose $\mathrm{C} 1 \mathrm{~N}, \mathrm{C} 1 \mathrm{R}, \mathrm{C} 2 \mathrm{~S}, \mathrm{C} 2 \mathrm{~L}$ su skirtingais cementais $1 \mathrm{~cm}$ atstumu nuo kaitinamo paviršiaus kaitinant vienpusiu būdu

Fig. 3.1. The temperature distribution of the concrete samples C1N, C1R, C2S, C2L with different cement from $1 \mathrm{~cm}$ distance from the heated surface of the one side heating 
Bandiniuose su skirtingais cementais $1 \mathrm{~cm}$ atstumu nuo kaitinamo paviršiaus, temperatūra kyla tolygiai pagal logaritminę kreivę, pateiktą 2.9 paveiksle. Kreivès forma panaši ị standartinio gaisro kreivę. Pradžioje iki 20 minučių betono temperatūra žymiai skiriasi nuo aplinkos temperatūros pagal standartinę gaisro kreivę, o po 3 valandų aplinkos ir bandinio temperatūros beveik susilygina. Bandymo pradžioje fiksuojama didesnè duomenų sklaida, bandymo pabaigoje duomenų sklaida sumažèja. Aukščiausia temperatūra po trijų valandų kaitinimo, kuri siekia $977{ }^{\circ} \mathrm{C}$ gauta su smulkiai maltu cementu (C1R). Kitų cementų temperatūros pasiskirto intervale $947-967{ }^{\circ} \mathrm{C}$. Mažiausia temperatūra $\left(947^{\circ} \mathrm{C}\right)$ užfiksuota betono bandinyje su cementu, kuriame nèra priedų $(\mathrm{C} 1 \mathrm{~N})$.

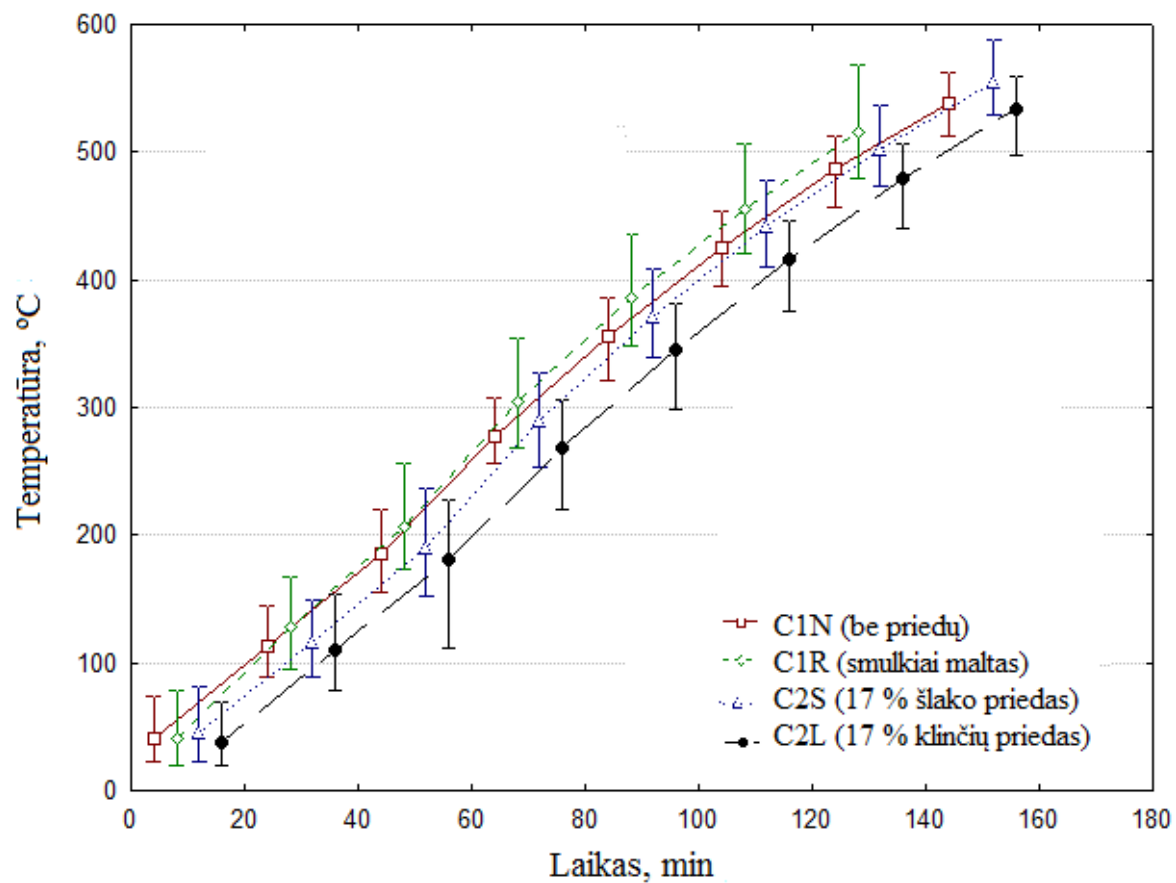

3.2 pav. Temperatūros pasiskirstymas betono bandiniuose $\mathrm{C} 1 \mathrm{~N}, \mathrm{C} 1 \mathrm{R}, \mathrm{C} 2 \mathrm{~S}, \mathrm{C} 2 \mathrm{~L}$ su skirtingais cementais $5 \mathrm{~cm}$ atstumu nuo kaitinamo paviršiaus kaitinant vienpusiu būdu

Fig. 3.2. The temperature distribution of the concrete samples C1N, C1R, C2S, C2L with different cement from $5 \mathrm{~cm}$ distance from the heated surface of the one side heating

Bandiniuose su skirtingais cementais nustatant temperatūros pasiskirstymą $5 \mathrm{~cm}$ atstumu nuo kaitinamo paviršiaus matomas beveik tiesinis temperatūros pokytis laiko bėgyje. Duomenų sklaida tiek bandymo pradžioje, tiek pabaigoje yra vienoda. Aukščiausios temperatūros fiksuojamos betono bandiniuose su smulkiai maltu cementu (C1R), po trijų valandų siekia $613{ }^{\circ} \mathrm{C}$, kituose cemen- 
tuose registruojami tokie rezultatai: cemente turinčiame $17 \%$ šlako priedo (C2S) pasiekta $608^{\circ} \mathrm{C}$ temperatūra, su cementu neturinčiu mineralinių priedų ir cementu turinčiu $17 \%$ klinties priedo pasiekta $589^{\circ} \mathrm{C}$ temperatūra.

Bandiniuose po 3 valandų kaitinimo su daug aukštakrosnių šlako turinčiu cementu (70\%), temperatūros pasiskirstymo nepavyko užfiksuoti, nes ịvyko bandinio sprogstamoji irtis. Temperatūros pasiskirstymo kreivès ịvairiuose bandinio sluoksniuose iki trisdešimties minučių pateikiamos 3.3 paveiksle.

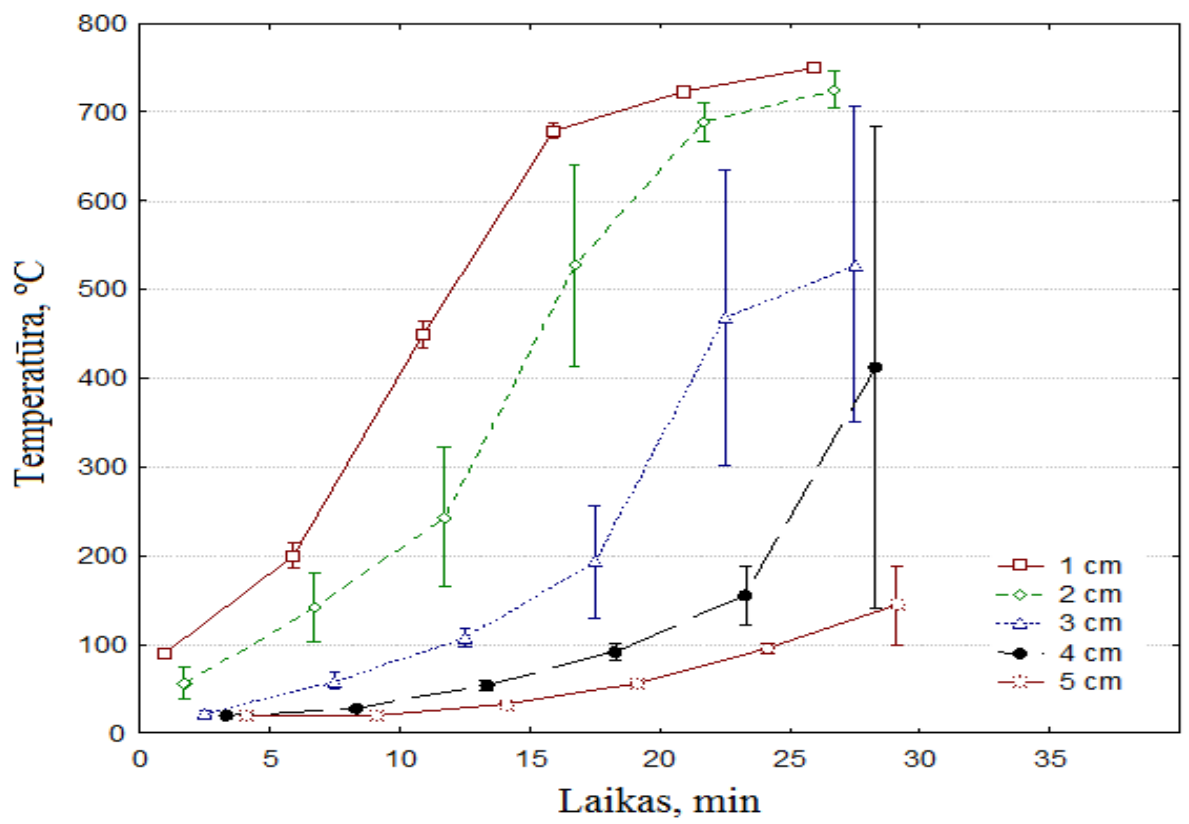

3.3 pav. Temperatūros pasiskirstymas betono bandiniuose (C3) su CEM III/B 32,5 NLH/SR (su $70 \%$ aukštakrosnių šlako priedu) kaitinant vienpusiu būdu

Fig. 3.3. Temperature distribution in concrete samples (C3) with CEM III / B32,5 N$\mathrm{LH} / \mathrm{SR}$ (with $70 \%$ blast furnace slag) of the one side heating

Bandiniuose su cementu turinčiame apie $70 \%$ aukštakrosnių šlako vyksta sprogstamoji irtis, dèl to duomenų sklaida yra didelè. $1 \mathrm{~cm}$ atstumu nuo kaitinamo paviršiaus po 30 minučių yra pasiekiama $750{ }^{\circ} \mathrm{C}$ temperatūra, $5 \mathrm{~cm}$ atstumu nuo kaitinamo paviršiaus yra pasiekiama $145{ }^{\circ} \mathrm{C}$ temperatūra. Iš 3.3 paveikslo galime matyti, kad vykstant intensyviam bandinio paviršiaus irimui, susidaro didelis temperatūrų skirtumas tarp paviršinio sluoksnio ir bandinio centro.

Siekiant išvengti betono bandinio sprogstamosios irties, buvo atlikti išdžiovinto $160{ }^{\circ} \mathrm{C}$ temperatūroje bandinio su šiuo cementu bandymai. Išdžiovin- 
to bandinio temperatūrinès kreivès skirtinguose sluoksniuose pateikiamos 3.4 paveiksle.

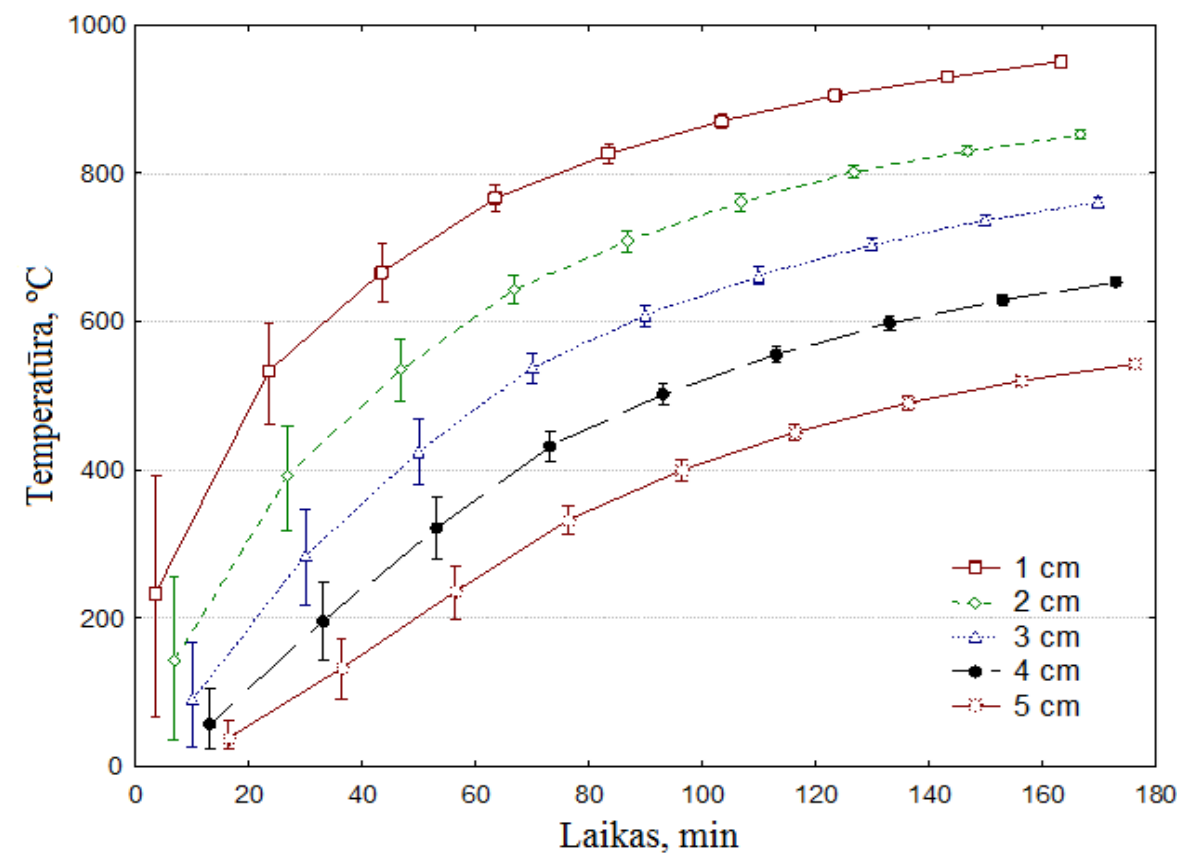

3.4 pav. Temperatūros pasiskirstymas betono bandinyje išlaikytame $160{ }^{\circ} \mathrm{C}$ temperatūroje (C3) su CEM III/B 32,5 N-LH/SR cementu (su 70 \% aukštakrosnių šlako priedu) kaitinant vienpusiu būdu

Fig. 3.4. Temperature distribution in the concrete sample passed at $160^{\circ} \mathrm{C}(\mathrm{C} 3)$ with the CEM III / B 32,5 N-LH / SR cement (containing 70\% of blast furnace slag) of the one side heating

Išdžiovintame bandinyje su dideliu kiekiu šlako, temperatūrų kilimas išoriniame ir centriniame sluoksniuose, buvo panašus kaip ir bandiniuose su kitais cementais tolygiai pagal logaritminę kreivę. Išdžiovinus bandinius su cementu turinčiu dideli kieki šlako, užfiksuotas 3,8 \% masès praradimas. Atlikus kaitinimą pagal standartinę vienpusio atsparumo ugniai bandymo metodiką, bandinio sprogstamoji irtis nebuvo užfiksuota.

Remiantis temperatūru pasiskirstymu bandinyje rezultatais, galima teigti, kad gaisro atveju yra pavojingiausias betonas, kuriame panaudotas cementas su dideliu šlako (apie $70 \%$ ) kiekiu t. y. CEM III tipo cementas. 


\subsubsection{Temperatūros pasiskirstymas betone su skirtingais cementais esant tūriniam temperatūros poveikiui}

Vykstant gaisrui, betoninès arba gelžbetoninès konstrukcijos gali būti veikiamos iš visų pusių, todèl buvo atliekami tyrimai, pasirenkant tūrinio atsparumo ugniai vertinimo metodiką. Temperatūros pasiskirstymo grafikai, betono bandinių su skirtingais cementais pateikiami 3.5-3.6 paveiksluose.

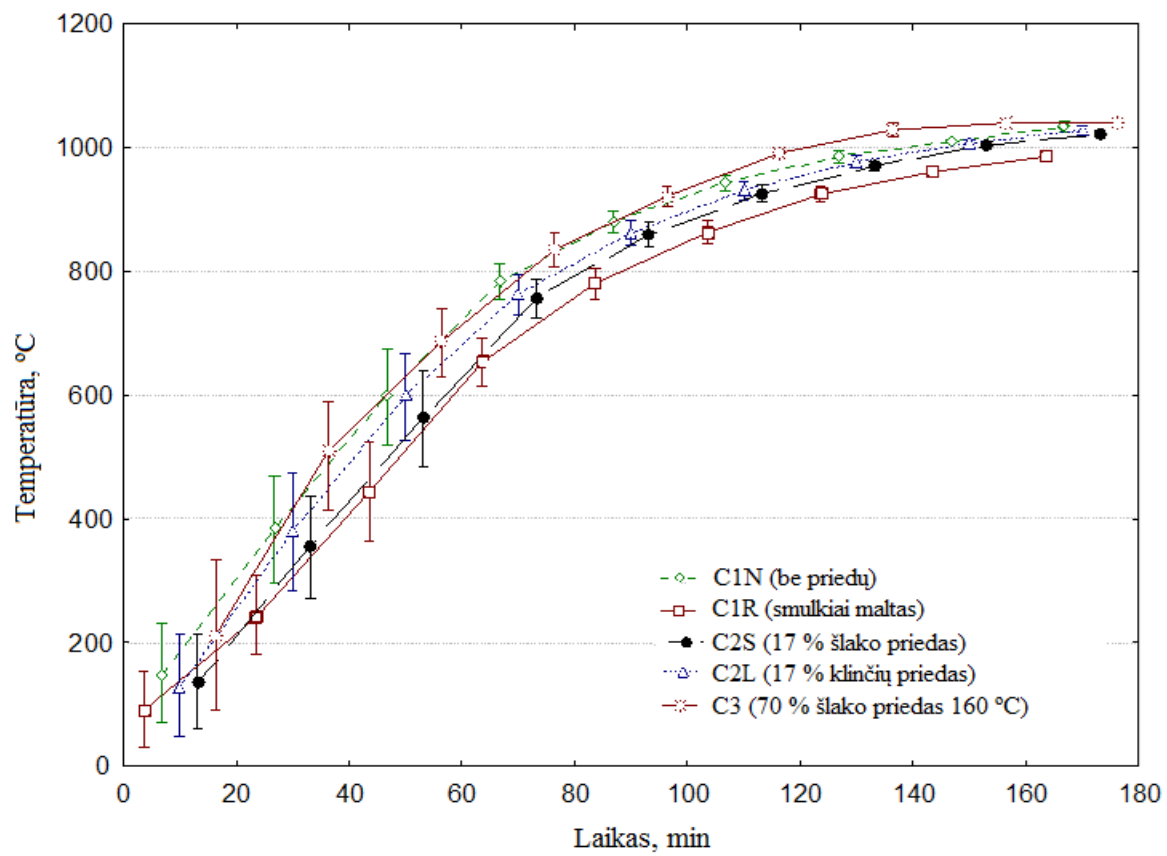

3.5 pav. Temperatūros pasiskirstymas betono bandiniuose C1N, C1R, C2S, C2L, C3 su skirtingais cementais $1 \mathrm{~cm}$ atstume kaitinant tūriniu būdu

Fig. 3.5. The temperature distribution of the concrete samples C1N, C1R, C2S, C2L, $\mathrm{C} 3$ with different cements $1 \mathrm{~cm}$ distance of volumetric heating

Bandiniuose su skirtingais cementais, $1 \mathrm{~cm}$ atstumu temperatūra kinta beveik tiesiškai iki $900{ }^{\circ} \mathrm{C}$ temperatūros, vèliau temperatūros kilimas sulèteja. Mažiausia temperatūra $991{ }^{\circ} \mathrm{C}$ po trijų valandų kaitinimo pasiekta betono bandiniuose, kurie suformuoti su smulkiai maltu cementu, neturinčiu mineralinių priedų. Bandiniuose su kitais cementais užfiksuotos temperatūros yra panašios: cemento be priedu $-1043{ }^{\circ} \mathrm{C}$, cemento su $17 \%$ klinties priedu $-1034{ }^{\circ} \mathrm{C}$, cemento su $17 \%$ šlako priedu $-1028{ }^{\circ} \mathrm{C}$, cemento su $70 \%$ šlako priedu ir išdžiovinto $160^{\circ} \mathrm{C}$ temperatūroje $-1039^{\circ} \mathrm{C}$. 


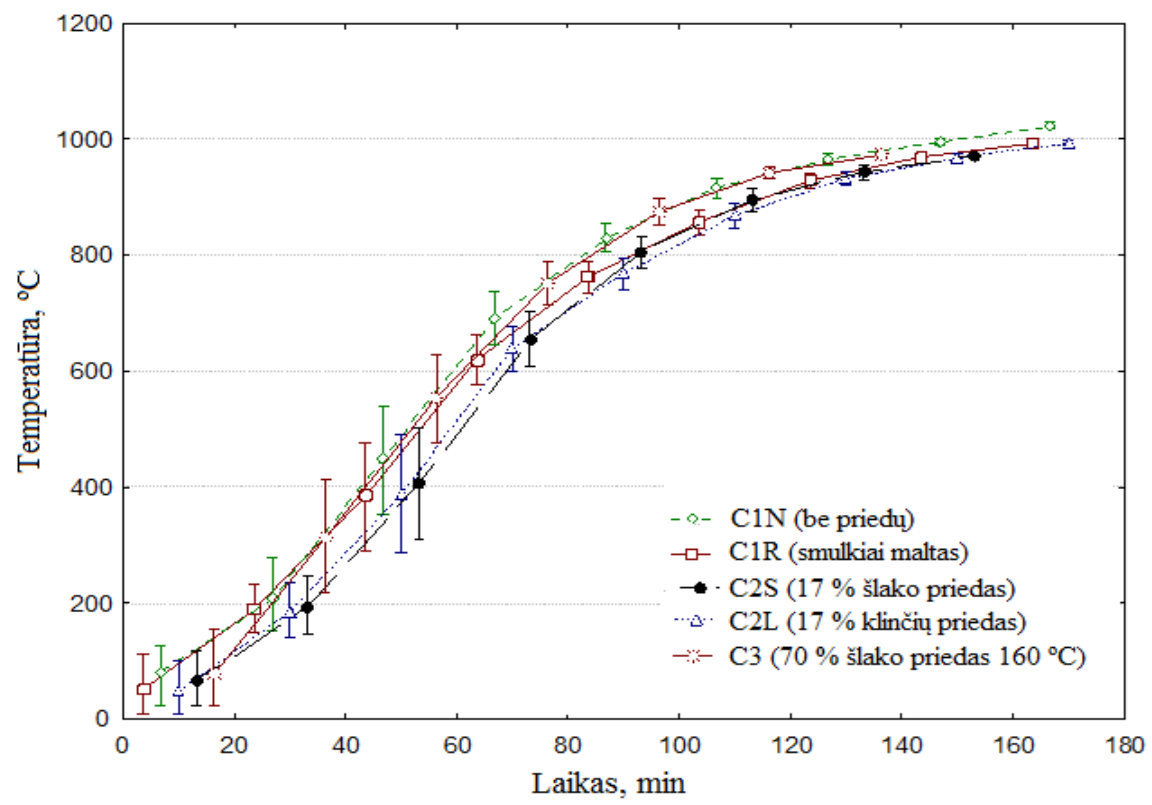

3.6 pav. Temperatūros pasiskirstymas betono bandiniuose su skirtingais cementais $5 \mathrm{~cm}$ atstume kaitinant tūriniu būdu

Fig. 3.6. The temperature distribution of the concrete samples with different cements $5 \mathrm{~cm}$ distance of volumetric heating

Betono bandiniuose su skirtingais cementais $5 \mathrm{~cm}$ atstumu nuo kaitinamo paviršiaus po 3 valandų kaitinimo pasiektos tokios temperatūros: betono su smulkiai maltu be priedų cementu $-997{ }^{\circ} \mathrm{C}$, su cementu be priedu $-1030{ }^{\circ} \mathrm{C}$, su cementu su klinties priedu $-998{ }^{\circ} \mathrm{C}$, su cementu su $17 \%$ šlako priedu $972{ }^{\circ} \mathrm{C}$, su cementu su $70 \%$ šlako priedu ir išdžiovinto $160{ }^{\circ} \mathrm{C}$ temperatūroje $976{ }^{\circ} \mathrm{C}$. Iš 3.5 ir 3.6 paveiksluose pateiktų kreiviu pastebèta, kad matuojant temperatūrų pasiskirstymą betono bandiniuose 1 ir $5 \mathrm{~cm}$ atstumu nuo kaitinamo paviršiaus nustatyti maži temperatūros skirtumai. Esant tūriniam bandymui šilumos perdavimas vyksta ne iš vienos pusès ị bandinio centrą o iš penkių skirtingų bandinio kraštinių, šiuo atveju gaunamas sudètingas šilumos perdavimo procesas ị bandinio centrą, kuris apsunkina bandymų rezultatų analizę. Remiantis atliktais vienpusio ir tūrinio kaitinimo bandymais nustatyta, kad šilumos perdavimo procesus betone geriau atspindi atlikti vienpusio kaitinimo tyrimų rezultatai. 


\subsubsection{Mineralinio priedo ịtaka cementinio akmens destrukciniams procesams}

Siekiant išsiaiškinti skirtingų tipų cemento ịtaką betono atsparumui ugniai, buvo atlikti termogravimetriniai tyrimai (TG, DTG) su cementiniu akmeniu. Tyrimui pasirinkti keturi skirtingi cementai: CEM I 42,5N (be priedų), CEM II/A-LL 42,5N (su $17 \%$ klinties priedu), CEM II/A-S 42,5N N (su $17 \%$ aukštakrosnių šlako priedu) ir CEM III/B 32,5N-LH/SR (su $70 \%$ aukštakrosnių šlako priedu). 3.7 paveiksle pateikta masès nuostolių veikiant temperatūrai kreivès (TG).

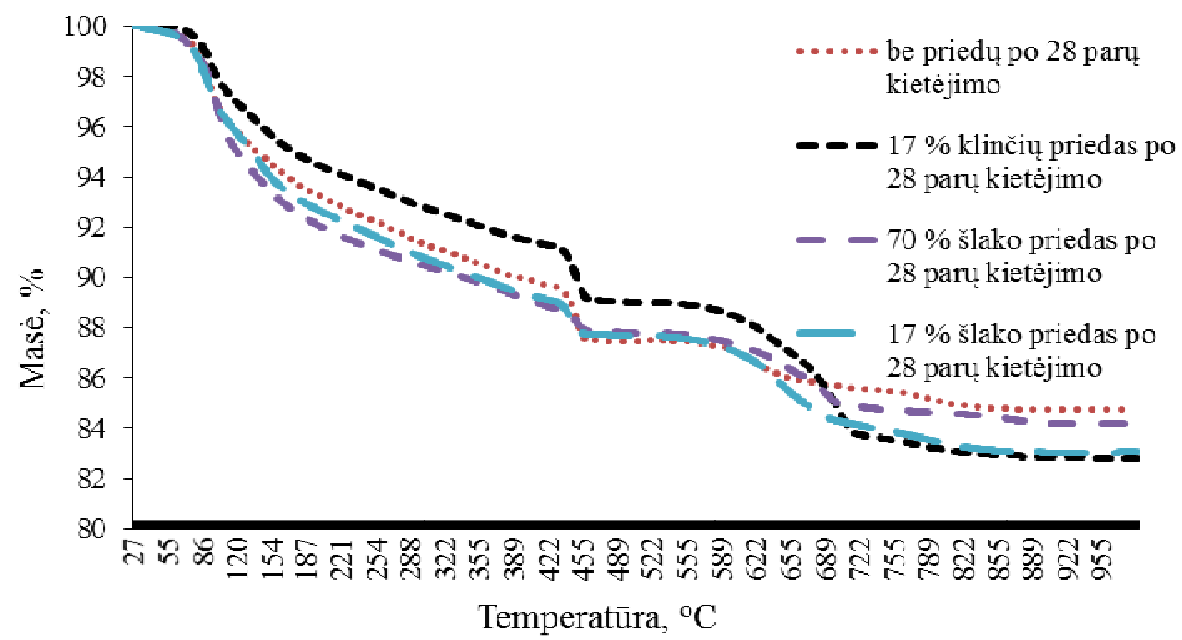

3.7 pav. Cementinio akmens su skirtingais mineraliniais priedais termogravimetrinès analizès kreivès po 28 parų kietejjimo

Fig. 3.7. Termogravimetric analysis curve of 28 days hardening of cement paste with different cement mineral additives

Remiantis termogravimetrinių tyrimų rezultatais (TG kreivėmis) galima ịvardinti cementinio akmens su skirtingais cemento mineraliniais priedais skirtumus:

$100-130{ }^{\circ} \mathrm{C}$ temperatūroje gauti masès nuostoliai charakterizuoja laisvo ir fiziškai surišto vandens kiekị cementiniame akmenyje. $100-130{ }^{\circ} \mathrm{C}$ temperatūroje didžiausi masès nuostoliai (4,3 \%) užfiksuoti su CEM III/B32,5 N-LH/SR tipo cementu, kurio sudettyje yra apie $70 \%$ aukštakrosnių šlako, mažiausi masès nuostoliai $(2,6 \%)$ užfiksuoti su CEM II A-LL 42,5N, kuriame yra $17 \%$ klinties priedo, su CEM I 42,5N užfiksuota 3,4 \%, su CEM II A-S 42,5N užfiksuota 3,8 \% masès nuostoliai. Šie masès nuostoliai paaiškinami laisvo ir adsorbuoto vandens pasišalinimu iš gelio pavidalo kalcio hidrosilikatų ir etringito.

$140-170{ }^{\circ} \mathrm{C}$ temperatūroje didžiausi masès nuostoliai užfiksuoti $(7,3 \%) \mathrm{su}$ CEM III/B32,5 N-LH/SR tipo cementu, mažiausi masès nuostoliai $(5,0 \%)$ 
užfiksuoti su CEM II A-LL 42,5N, su CEM I 42,5N užfiksuota 6,0 \%, su CEM II A-S $42,5 \mathrm{~N}$ užfiksuota $6,8 \%$. Šie masès nuostoliai paaiškinami heksagonalinio hidroaliuminato suirimu.

$430-470{ }^{\circ} \mathrm{C}$ temperatūroje didžiausi masès nuostoliai užfiksuoti $(12,5 \%)$ su CEM I 42,5N tipo cementu, mažiausi masès nuostoliai (10,9\%) užfiksuoti su CEM II A-LL 42,5N, su CEM III/B32,5 N-LH/SR užfiksuota (12,2 \%), su CEM II A-S 42,5N užfiksuota (12,3 \%). Masès nuostolius galima aiškinti kalcio hidrosilikatų dehidratacija. Cemente be mineralinių priedų yra didžiausias kalcio hidrosilikatu kiekis.

$670-730{ }^{\circ} \mathrm{C}$ temperatūros didžiausi masès nuostoliai užfiksuoti $(16,6 \%)$ su CEM II A-LL 42,5N tipo cementu, mažiausi masès nuostoliai $(14,6 \%)$ užfiksuoti su CEM I 42,5N, su CEM III/B32,5 N-LH/SR užfiksuota (15,3\%), su CEM II A-S 42,5N užfiksuota (16,2\%). Šis masės nuostolis paaiškinamas kalcio ir magnio karbonatų skilimu.

Bandymai atliekami iki $1000{ }^{\circ} \mathrm{C}$, gauti bendri masès nuostoliai: CEM I 42,5N - 15,2 \%, CEM II A-LL 42,5N - 17,2 \%, CEM III/B32,5 N-LH/SR $15,8 \%$, CEM II A-S 42,5N - 16,9\%.

Siekiant įvertinti betono hidrataciją po ilgesnio laiko tarpo buvo atlikti papildomi termogravimetriniai tyrimai su skirtingais cementais po pusantrų metų hidratacijos laikotarpio. Masès nuostolių TG kreivès pateiktos 3.8-3.9 paveiksluose.

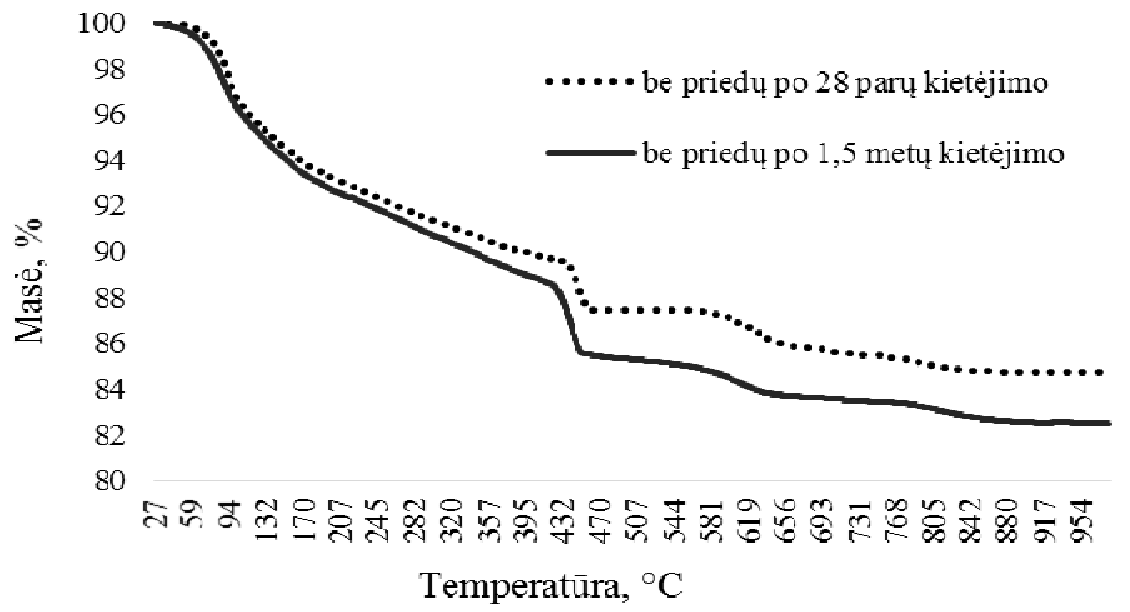

3.8 pav. Cementinio akmens be priedų po 28 parų ir 1,5 metų kietejjimo termogravimetrinès kreivès

Fig. 3.8. Termogravimetric analysis curves of hardening cement paste without additives after 28 days and 1.5 years 
$100-130{ }^{\circ} \mathrm{C}$ temperatūroje cementiniame akmenyje po 28 paru ir 1,5 metų gauti tokie rezultatai: po 28 paru gautas masès nuostolis $-3,4 \%$, kietinant 1,5 metu $-3,8 \%$.

$140-170{ }^{\circ} \mathrm{C}$ temperatūroje 28 paras kietintas cementas praranda $6,1 \%$, po 1,5 metų masès nuostoliai užfiksuoti $6,5 \%$, didesni masès nuostoliai užfiksuoti prie $430-470{ }^{\circ} \mathrm{C}$ temperatūros: po 28 paru masès nuostoliai siekia $12,5 \%$, po 1,5 metu $-14,6 \%$. Tai rodo, kad per minètą laikotarpi vyko intensyvi cemento hidratacija ir buvo gautas žymus kalcio hidrosilikatų kiekio padidejjimas. 670$730{ }^{\circ} \mathrm{C}$ temperatūroje po 28 paru masès nuostoliai užfiksuoti $14,6 \%$, po 1,5 metų kietinimo - 16,6 \%. Nuo 28 parų iki 1,5 metų kietinant cementini akmeni užfiksuotas apie $2 \%$ bendrų masès nuostolių skirtumas, kuris mažai padideja nuo $470{ }^{\circ} \mathrm{C}$ temperatūros. Tai reiškia, kad po ilgo hidratacijos laiko susidaro didesni kiekiai kalcio hidrosilikatų.

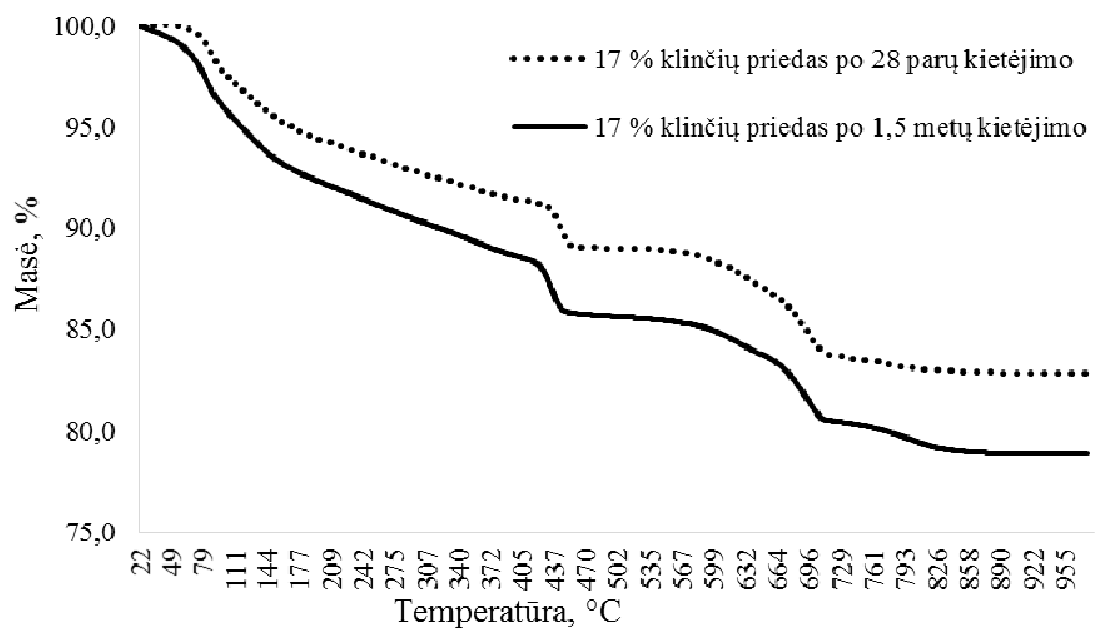

3.9 pav. Cementinio akmens su $17 \%$ klinties priedu po 28 parų ir 1,5 metų kietejjimo termogravimetrinès kreivès

Fig. 3.9. Termogravimetric analysis curves of hardening cement paste with $17 \%$ limestone additives after 28 days and 1.5 years

Cemente, kuriame yra klinties priedo, $100-130{ }^{\circ} \mathrm{C}$ temperatūroje gauti tokie rezultatai: po 28 parų kietinimo masès nuostoliai užfiksuoti $2,6 \%$, po 1,5 metu $-4,3 \%, 140-170{ }^{\circ} \mathrm{C}$ temperatūroje po 28 parų hidratacijos prarandama $5,0 \%$, po 1,5 metu kietinimo $-7,2 \%, 430-470{ }^{\circ} \mathrm{C}$ temperatūroje po 28 parų kietinimo užfiksuoti masès nuostoliai siekia $10,9 \%$, po 1,5 metu $-14,3 \%$, $670-730{ }^{\circ} \mathrm{C}$ temperatūroje po 28 parų kietinimo prarandama $16,5 \%$, po 1,5 
metų - 19,8 \%. Bendri masès nuostoliai po 1,5 metų yra $5 \%$ didesni, todèl galima teigti, kad po ilgos eksploatacijos trukmès tokio betono su tokiu cementu atsparumas ugniai mažeja. İvertinus skaitinius duomenis, galima teigti, kad didesni masès nuostoliai po 1,5 metų kietejjimo fiksuojami pirmame etape, kai šalinasi laisvasis vanduo, trečiame etape, kai vyksta kalcio hidrosilikatų dehidratacija ir ketvirtame etape, kai vyksta karbonatų skilimas.

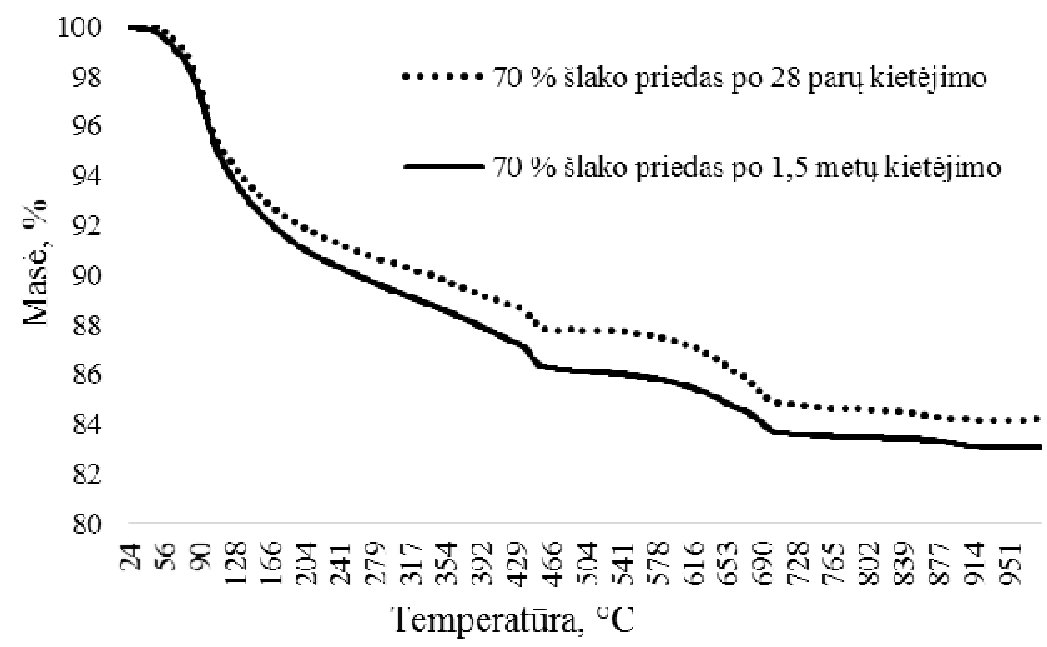

3.10 pav. Cementinio akmens su $70 \%$ šlako priedų po 28 parų ir 1,5 metų kietėimo termogravimetrinès kreivès

Fig. 3.10. Termogravimetric analysis curve of hardening cement paste with $70 \%$ slag additives after 28 days and 1.5 years

Iš kreivių pastebima, kad cemente, kuriame yra didelis kiekis aukštakrosnių šlako $(70 \%)$, skirtumai yra mažesni lyginant cementą, turintị klinties priedo. $100-130{ }^{\circ} \mathrm{C}$ temperatūroje gauti tokie rezultatai: po 28 parų kietinimo masès nuostolis užfiksuotas $4,2 \%$, po 1,5 metų $-4,5 \%, 140-170{ }^{\circ} \mathrm{C}$ temperatūroje po 28 parų hidratacijos prarandama $7,3 \%$, po 1,5 metu kietinimo - 8,0 \%, 430-470 ${ }^{\circ} \mathrm{C}$ temperatūroje po 28 parų kietinimo užfiksuotas masès nuostolis siekia $12,2 \%$, po 1,5 metu $-13,7 \%, 670-730{ }^{\circ} \mathrm{C}$ temperatūroje po 28 parų kietinimo prarandama $15,3 \%$, po 1,5 metu $-16,5 \%$. Ivertinus skaitinius duomenis, galima teigti, kad didžiausias masès nuostolių padidèjimas užfiksuotas trečiajame etape, kai vyksta kalcio hidrosilikatų dehidratacija. Nežymus bendrų masès nuostoliu padidèjimas cementiniame akmenyje su šlako priedu apie $1 \%$ rodo didesni atsparumą ugniai.

Masès pokyčių greitis (DTG kreivès) po 28 parų kietinimo ir 1,5 metų pateiktas 3.11-3.14 paveiksluose. 


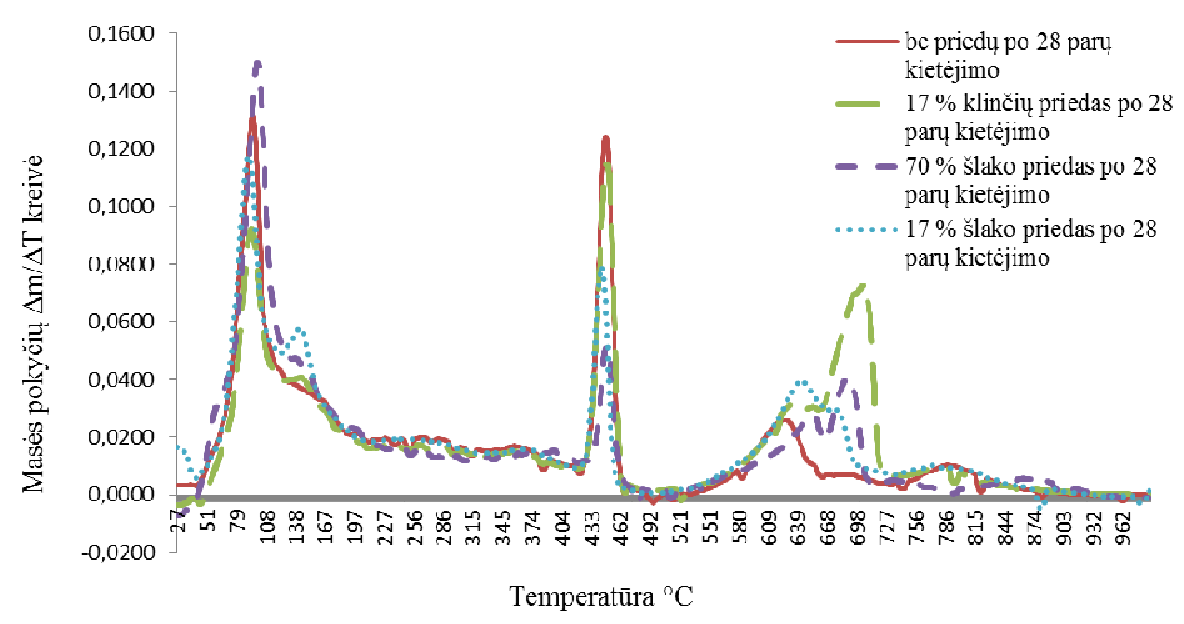

3.11 pav. Cementinio akmens su skirtingais mineraliniais priedais diferencinès termogravimetrijos kreivès

Fig. 3.11. Differential termogravimetric curves of hardening cement paste with different cement mineral additives

DTG kreivè su skirtingais mineraliniais priedais rodo masės pokyčių greiti priklausomai nuo temperatūros. Didžiausias greitis pirmame etape (smailè $105{ }^{\circ} \mathrm{C}$ ) pasiekiama su cementu, kuriame yra $70 \%$ aukštakrosnių šlako, mažiausias masès pokyčio greitis užfiksuotas su cementu turinčiu $17 \%$ klinties priedo. Su šlako priedo turinčiais cementais užfiksuota papildoma smaile prie $140{ }^{\circ} \mathrm{C}$ temperatūros charakterizuojanti hidroaliuminatų skilimą, kurie susidaro hidratuojant aliuminatams esantiems šlake, irstant hidroaliuminatui didžiausias masès nuostoliu greitis pasiektas su cementu, kuriame yra $17 \%$ šlako priedo, mažiausias cemente be priedų. Trečiame etape (smailè $450{ }^{\circ} \mathrm{C}$ ) prarandant chemiškai surištą vandeni iš kalcio hidrosilikatų, didžiausias masès pokyčių greitis fiksuojamas su cementu, kuriame nèra priedu, mažiausias greitis fiksuojamas su daug šlako turinčiu cementu. Tai rodo, kad didžiausias kalcio hidrosilikatų kiekis susidaro cemente be priedų, mažesni - cemente su šlako priedu. Kuo didesnis šlako kiekis cemente, tuo mažesnis kalcio hidrosilikatų kiekis dèl lètesnès tokio cemento hidratacijos. Ketvirtame etape (smaile $640{ }^{\circ} \mathrm{C}$ ) skylant kalcio hidroksidui $\left(\mathrm{Ca}(\mathrm{OH})_{2}\right)$ užfiksuotas cemente be priedų. Penktame etape (smailè $700{ }^{\circ} \mathrm{C}$ ) skylant kalcio ir magnio karbonatams didžiausi pokyčiai užfiksuoti su cementu turinčiu klinčių priedą, mažiausi pokyčiai fiksuoti su cementu neturinčiu priedų. Siekiant įvertinti ilgą cemento hidratacijos procesą, buvo atlikti tyrimai su skirtingais cemento mineraliniais priedais po 1,5 metu hidratacijos. Masès pokyčiu greičio kreivès po 28 paru kietejjimo ir 1,5 metų kietèjimo pateiktos 3.12-3.14 paveiksluose. 


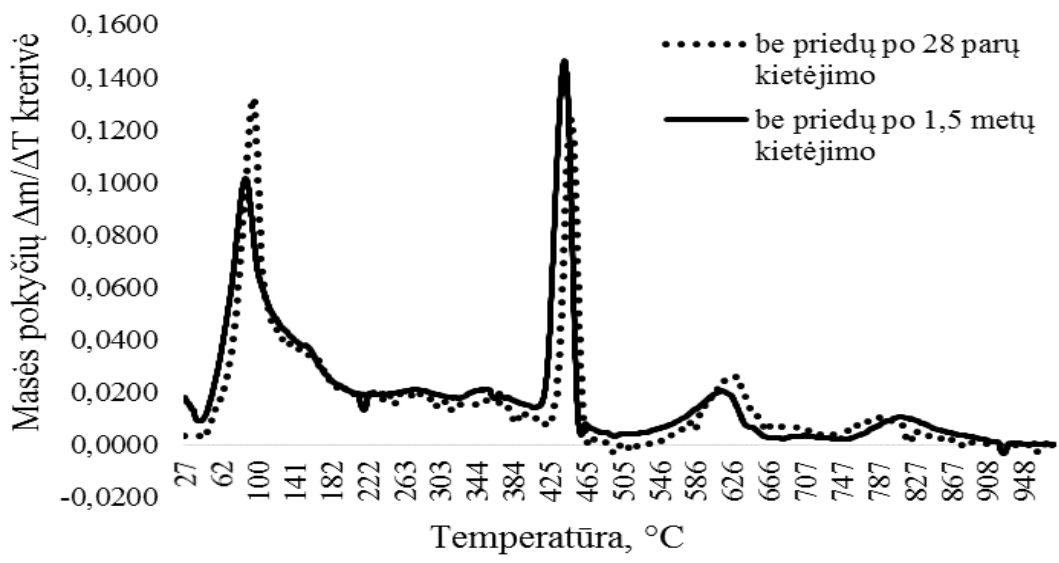

3.12 pav. Cementinio akmens be priedų po 28 parų ir 1,5 metų kietèjimo diferencinès termogravimetrijos kreivès

Fig. 3.12. Differential termogravimetric curves of hardening cement paste without additives after 28 days and 1.5 years

Iš 3.12 paveiksle pateiktų kreivių matosi, kad didžiausi skirtumai užfiksuoti pirmame ir trečiame etape, kurie parodo, kad po ilgesnio hidratacijos laikotarpio laisvojo vandens sumažeja, bet padidejja kalcio hidrosilikatų, kituose etapuose duomenys panašūs.

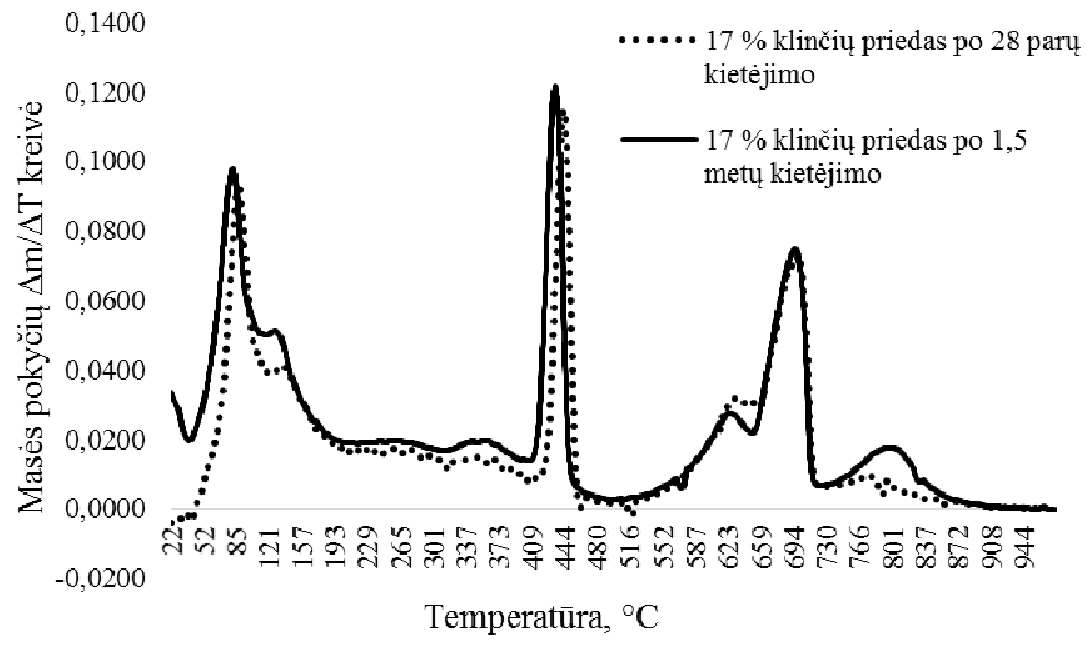

3.13 pav. Cementinio akmens su $17 \%$ klinčių priedu po 28 parų ir 1,5 metụ kietėjimo diferencinès termogravimetrijos kreivès

Fig. 3.13. Differential termogravimetric curves of hardening cement paste with $17 \%$ limestone additives after 28 days and 1.5 years 
Iš 3.13 paveiksle pateiktų kreivių užfiksuotas nežymus padidejjimas pirmame ir trečiame etape, kurie parodo laisvojo vandens ir kalcio hidrosilikatų nežymų padidèjimą po ilgo hidratacijos laikotarpio, kituose etapuose duomenys panašūs.

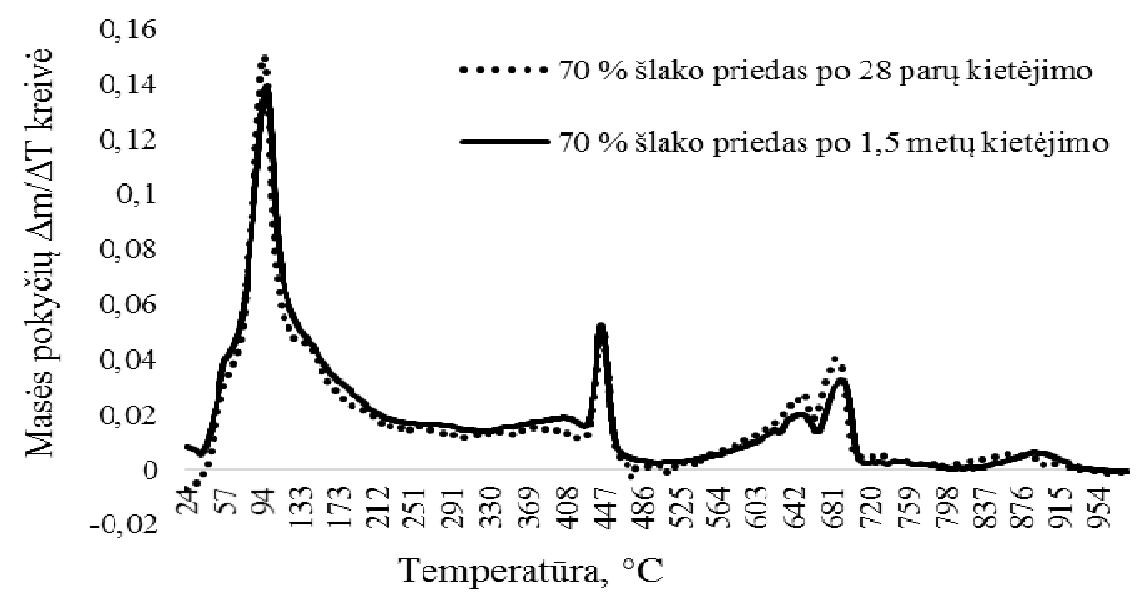

3.14 pav. Cementinio akmens su $70 \%$ šlako priedu po 28 parų ir 1,5 metų kietėjimo diferencinès termogravimetrijos kreivès

Fig. 3.14. Differential termogravimetric curves of hardening cement paste with $70 \%$ slag additives after 28 days and 1.5 years

Atlikus tyrimus su daug šlako turinčiu cementu (3.14 pav.), DTG kreivè arba masés pokyčiu greitis po 28 parų ir 1,5 metų hidratacijos rodo labai nedideli laisvojo vandens pokyti. Po ilgos hidratacijos trukmès laisvojo vandens nežymiai sumažèja o kalcio hidrosilikatų kiekis išlieka tas pats.

Siekiant išsiaiškinti skirtumus tarp cementų su skirtingais mineraliniais priedais buvo atlikti infraraudonujų spindulių spektroskopijos tyrimai. Gauti spektrai pavaizduoti 3.15-3.18 paveiksluose. Gautos IR kreivès rodo skirtumus tarp cemento mineralinių priedų (3.15 pav.). Kai bangos ilgis yra $874 \mathrm{~cm}^{-1}$ atsiranda kalcio karbonatu virpejjimas $\left(\mathrm{CO}_{3}\right)$, kurių didesnis kiekis užfiksuotas cemente su $70 \%$ ir $17 \%$ šlako kiekiu. Kai bangos ilgis yra $965 \mathrm{~cm}^{-1}$ atsiranda $\mathrm{SiO}_{4}$ vibracija. Kai bangos ilgis yra $1477 \mathrm{~cm}^{-1}$ ir $1422 \mathrm{~cm}^{-1}$ atsiranda karbonatu $\left(\mathrm{CO}_{3}\right)$ virpejjimas, kurių didžiausias kiekis cemente su $17 \%$ klinties priedu. Kai bangos ilgis yra $1657 \mathrm{~cm}^{-1}$ ir $3431 \mathrm{~cm}^{-1}$ užfiksuotas vandens molekulių $\left(\mathrm{H}_{2} \mathrm{O}\right)$ virpejimas. Kai bangos ilgis yra $3642 \mathrm{~cm}^{-1}$ atsiranda kalcio hidroksido $(\mathrm{OH})$ virpèjimas. 


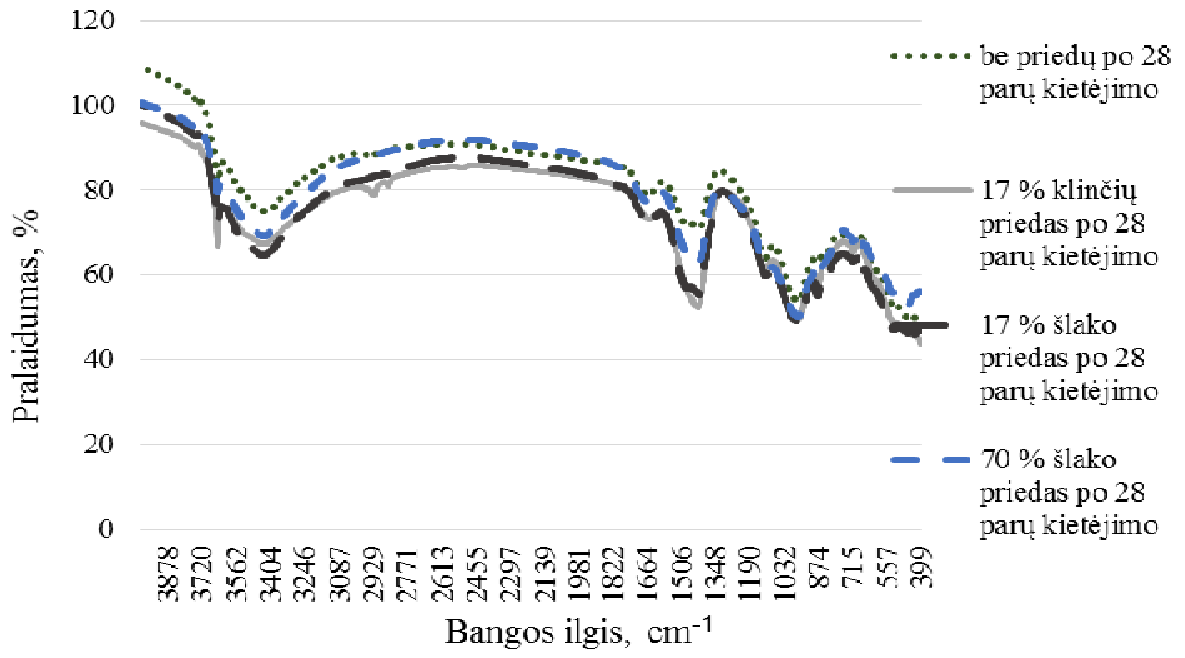

3.15 pav. Cementinio akmens su skirtingais cemento mineraliniais priedais po 28 parų kietėjimo infraraudonujų spindulių spektroskopinės kreivès

Fig. 3.15. Infrared spectroscopy curves of hardening cement paste with different cement mineral additives after 28 days

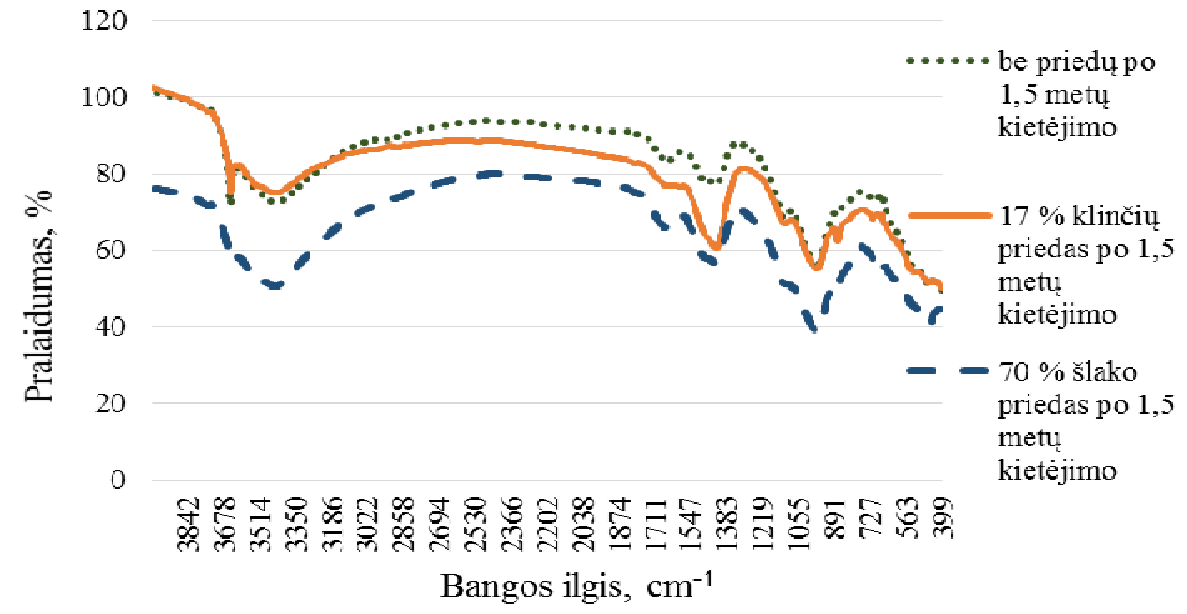

3.16 pav. Cementinio akmens su skirtingais cemento mineraliniais priedais po 1,5 metų kietejjimo infraraudonųjų spindulių spektroskopinės kreivès

Fig. 3.16. Infrared spectroscopy curves of hardening cement paste with different cement mineral additives after 1.5 years

Atlikus cementinio akmens su skirtingais priedais tyrimus po 1,5 metu (3.16 pav.) pastebimi didesni hidratacijos skirtumai cemente su $70 \%$ šlako 
priedu. Pagrindiniai skirtumai atsiranda kai bangos ilgis yra $965 \mathrm{~cm}^{-1}$, kur fiksuojama $\mathrm{SiO}_{4}$ vibracija ir bangos ilgiui $3431 \mathrm{~cm}^{-1}$, kur fiksuojama vandens molekulių $\left(\mathrm{H}_{2} \mathrm{O}\right)$ virpejjimas.

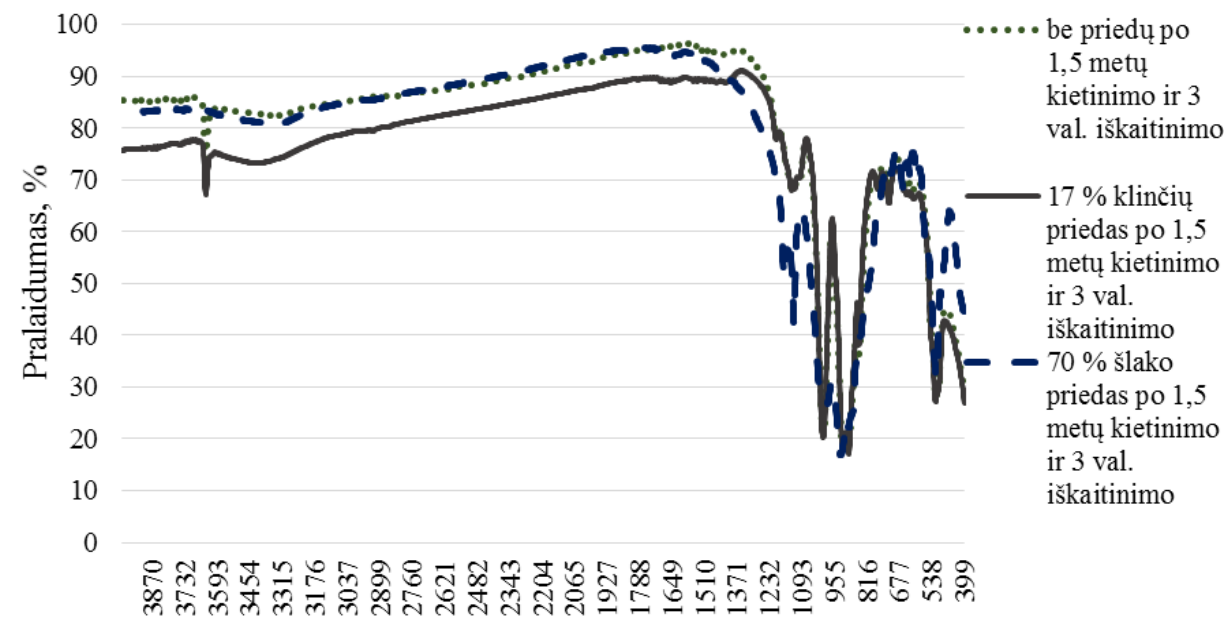

Bangos ilgis, $\mathrm{cm}^{-1}$

3.17 pav Cementinio akmens su skirtingais cemento mineraliniais priedais po 1,5 metu

kietėjimo ir 3 valandų temperatūrinio poveikio infraraudonųjų spindulių spektroskopinès kreivès

Fig. 3.17. Infrared spectroscopy curves of hardening cement paste with different cement mineral additives after 1.5 years and 3 hours of heating

Atlikus bandymus su cementiniu akmeniu su skirtingais cemento mineraliniais priedais, kuris buvo kaitinamas 3 valandas pagal standartinę gaisro kreivę (3.17 pav.), pastebimas žymus kreivių pokytis. Kai bangos ilgis yra $464 \mathrm{~cm}^{-1}$ tada atsiranda $\mathrm{SiO}_{4}$ vibracija. Kai bangos ilgis yra $874 \mathrm{~cm}^{-1}$ atsiranda $\mathrm{CO}$ molekulių vibracija. Nebelieka $\mathrm{H}_{2} \mathrm{O}$ vibracijos ties $3431 \mathrm{~cm}^{-1}$ bangos ilgiu. Šie rezultatai rodo kalcio hidroksido išnykimą cementiniuose bandiniuose po temperatūrinio poveikio ir labai mažą vandens kiekị, arba visišką jo nebuvimą.

Galima pabrezžti, kad didelių skirtumų IR spektruose nepastebèta ir IR spektrai nèra jautrūs kiekybiniams atskirų grupių pokyčiams.

\subsubsection{Mineralinio priedo įtaka betono savybių pokyčiams veikiant aukštai temperatūrai}

Betono masès nuostoliai gauti kaitinant vienpusiu atsparumo ugniai vertinimo metodu ir nustatyti remiantis šio darbo 2.5 .2 skyrelyje aprašytu apskaičiavimu. Masès nuostoliai betone su skirtingais cementais pateikti 3.1 lentelèje. 
3.1 lentelè. Masès nuostoliai betono bandiniuose su skirtingais cementais

Table 3.1. Weight loss of concrete samples with different cements

\begin{tabular}{|c|c|}
\hline Sudèties žymuo & Masés nuostolis po 3 val. kaitinimo, $\%$ \\
\hline C1N (be priedo) & 8,3 \\
\hline C1R (smulkiai maltas) & 8,29 \\
\hline C2L (17 \% klinčiu priedas) & 8,98 \\
\hline C2S (17\% šlako priedas) & 9,1 \\
\hline C3 (70 \% šlako priedas) & 50,5 (po 30 min)* \\
\hline
\end{tabular}

* - sprogstamasis irimas

Betono su skirtingais cementais masès nuostoliai kinta nuo 8,29-9,1\%, tai rodo, kad mineralinis priedas cemente neturi didelès įtakos cementinio akmens irimo procesams veikiant aukštai temperatūrai. Su 70 \% šlako turinčiu cementu (C3), dèl vykstančios sprogstamosios irties atsiranda dideli masès nuostoliai. Jie atsiranda dèl didelio kiekio laisvojo vandens pasišalinimo ir sukeliamos cementinès matricos destrukcijos. Bandymu metu praejjus 30 minučių, buvo užfiksuotas 50,5\% masès nuostolis. Gauti dideli masès nuostoliu skirtumai nuo $8,3 \%$ iki $50,5 \%$, parodo betoninių konstrukciju galimą elgseną ugnyje ir keliamą pavojų laikančioms konstrukcijoms panaudojus netinkamą cementą.

Ultragarso sklidimo greičio sumažejimas betone su skirtingais cementais nustatytas remiantis šio darbo 2.5.2 skyrelyje aprašyta metodika. Gauti rezultatai pateikti 3.2 lenteleje. Suformuotose betono bandiniuose su skirtingais cementais, ultragarsas greičiausiai sklinda su $17 \%$ turinčiu klinties priedo, mažiausias sklidimo greitis užfiksuotas su cementu be priedu. Paveikus betono bandinius temperatūra 3 valandas iš vienos pusès pagal standartinę temperatūros - laiko kreive, didžiausias ultragarso sklidimo greičio sumažèjimas gautas su $17 \%$ šlako turinčiu cementu $(40,9 \%)$. Mažiausi pokyčiai užfiksuoti betone su smulkiai maltu cementu $(20,6 \%)$ ir su $17 \%$ klinties turinčiu cementu $(23,9 \%)$. Ultragarso sklidimo greičio nepavyko užfiksuoti betone su $70 \%$ šlako turinčiu cementu, nes bandiniai suiro sprogstamosios irties būdu.

3.2 lentelè. Ultragarso sklidimo greitis betono bandiniuose su skirtingais cementais Table 3.2. Ultrasonic velocity of concrete samples with different cements

\begin{tabular}{|c|c|c|c|}
\hline Sudeties žymuo & $\begin{array}{c}\text { Ultragarso skli- } \\
\text { dimo greitis } \\
\text { prieš kaitinimą, } \\
\mathrm{m} / \mathrm{s}\end{array}$ & $\begin{array}{c}\text { Ultragarso skli- } \\
\text { dimo greitis po } \\
\text { 3 val. kaitinimo, } \\
\mathrm{m} / \mathrm{s}\end{array}$ & $\begin{array}{c}\text { Ultragarso } \\
\text { sklidimo } \\
\text { greičio suma- } \\
\text { žèjimas, \% }\end{array}$ \\
\hline C1N (be priedo) & 3984 & 2558 & 35,8 \\
\hline C1R (smulkiai maltas) & 4028 & 3197 & 20,6 \\
\hline C2L (17\% klinties priedas) & 4143 & 3154 & 23,9 \\
\hline C2S (17\% šlako priedas) & 4032 & 2382 & 40,9 \\
\hline C3 (70 \% šlako priedas) & 4030 & Nenustatyta* & - \\
\hline * - sprogstamasis irimas & \multicolumn{3}{|l}{} \\
\hline
\end{tabular}


3.18 paveiksle pateikti betono su šamoto užpildu ir skirtingais cementais temperatūrinių deformacijų kreivès.

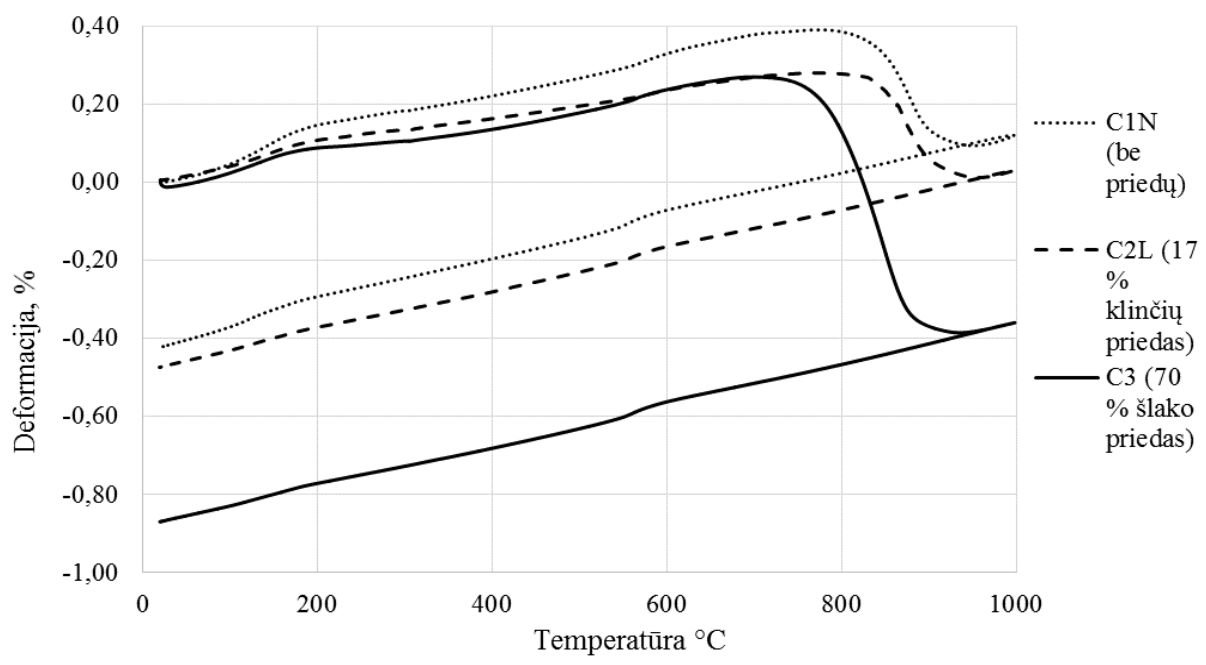

3.18 pav. Betono bandinių su skirtingais cementais terminis išsiplètimas ir susitraukimas

Fig. 3.18. Concrete samples thermal expansion and shrinkage with different cements

Didžiausias terminis plètimasis kaitinant užfiksuotas betono bandiniuose su cementu be mineralinių priedų $(\mathrm{C} 1 \mathrm{~N})$ ir siekia $0,4 \%$. Tačiau pasiekus apie $800{ }^{\circ} \mathrm{C}$ temperatūrą vyksta staigus cementinio akmens susitraukimas beveik iki pradinių bandinio matmenų. Vykstant bandinio aušinimui betono bandinys traukiasi analogiškai išsiplètimui ir pasiekia minusinę $-0,4 \%$ deformacijos reikšmę. Didžiausias betono susitraukimas prie $800{ }^{\circ} \mathrm{C}$ temperatūros vyksta su šlakiniu cementu, dèl didelio susidarančio skystosios fazès kiekio šiame cemente minètoje temperatūroje (Некрасов 1957). Aušinant betoną su šlakiniu cementu vyksta terminio susitraukimo deformacija analogiška kitų betonų susitraukimo deformacijoms. Temperatūrinès deformacijos betone yra labai svarbios dèl gniuždymo stiprio praradimų aiškinimo, nes vykstant deformacijoms suardoma kontaktinè zona tarp užpildo ir cementinès matricos, todèl paveikus betoną aukšta temperatūra yra prarandamas gniuždymo stipris ir gelžbetoninių konstrukcijų laikomoji galia.

Betono gniuždymo stipris nustatytas remiantis šio darbo 2.5 .2 poskyriuje aprašyta metodika. Betono bandinių, veikiamų temperatūrinio režimo pagal vienpusi atsparumo ugniai bandymų metodą, gniuždymo stiprio sumažejimas pateiktas 3.3 lentelèje. 
3.3 lentelè. Betono bandinių su skirtingais cementais gniuždymo stipris

Table 3.3. Concrete compressive strength of samples with different cements

\begin{tabular}{|c|c|c|c|c|c|}
\hline Rodikliai & $\begin{array}{c}\text { C1N (be } \\
\text { prieduc) }\end{array}$ & $\begin{array}{c}\text { C1R } \\
\text { (smulkiai } \\
\text { maltas) }\end{array}$ & $\begin{array}{c}\text { C2L (17\% } \\
\text { klinties } \\
\text { priedas) }\end{array}$ & $\begin{array}{c}\text { C2S (17 \% } \\
\text { šlako } \\
\text { priedas) }\end{array}$ & $\begin{array}{c}\text { C3 (70\% } \\
\text { šlako } \\
\text { priedas) }\end{array}$ \\
\hline $\begin{array}{c}\text { Gniuždymo stipris } \\
\text { prieš kaitinimą, MPa }\end{array}$ & 36,7 & 39,3 & 36,8 & 35,1 & 31,3 \\
\hline $\begin{array}{c}\text { Gniuždymo stipris po } \\
3 \text { val. kaitinimo, MPa }\end{array}$ & 25,8 & 28,7 & 32,2 & 24,4 & $\begin{array}{c}25,4 \\
\text { (po 30 min)* }\end{array}$ \\
\hline $\begin{array}{c}\text { Gniuždymo stiprio } \\
\text { sumažejimas, \% }\end{array}$ & 29,7 & 27,0 & 12,5 & 30,5 & $\begin{array}{c}18,8 \\
\text { (po 30 min)* }\end{array}$ \\
\hline
\end{tabular}

* - sprogstamasis irimas

Betono bandinių su skirtingais cementais gniuždymo stipris skiriasi. Gauti rezultatai rodo, kad didžiausią gniuždymo stiprị turi bandiniai su smulkiai maltu cementu (39,3 MPa), mažiausias gniuždymo stipris užfiksuotas su $70 \%$ šlako priedo turinčiu cementu (31,3 MPa). Atlikus vienpusio kaitinimo bandymus, paaiškejjo, kad didžiausi pokyčiai įvyko su bandiniais turinčiais aukštakrosnių šlako priedo. Betono bandinių su $17 \%$ šlako priedo turinčiu cementu gniuždymo stipris sumažejo 30,5 \%, su $70 \%$ šlako turinčiu cementu 18,8 \%. Reikia atkreipti dèmesi, kad betone su $70 \%$ turinčiu šlako priedo vyko sprogstamoji irtis ir šis rezultatas pateiktas po 30 minučių bandymo. Mažiausi gniuždymo stiprio pokyčiai įvyko bandiniuose su $17 \%$ klinties priedo turinčiu cementu $(12,5 \%)$. Šie rezultatai leidžia daryti išvadą, kad klinties priedas turi teigiamą itaką betono atsparumui ugniai. Galima daryti prielaidą, kad betono stiprumo sumažejjimui lemiamą itaką turi vandens kiekis ir cementinio akmens laidumas vandeniui ir jo garams. Cemente su klinties priedu yra mažesnis klinkerio kiekis ir po sukietejjimo yra gaunamas mažesnio tankio ir laidesnis cementinis akmuo. Kuo didesnis šlako kiekis tuo mažesnio laidumo cementinis akmuo susidaro ir mažejja betono atsparumas ugniai arba pasireiškia sprogstamoji irtis.

\subsection{Užpildụ ịtaka betono atsparumui ugniai}

\subsubsection{Temperatūros pasiskirstymas betone su skirtingais užpildais esant vienpusiam temperatūros poveikiui}

Vertinant skirtingų užpildų įtaką betono atsparumui ugniai, atlikti temperatūros pasiskirstymo bandinių skerspjūvyje tyrimai naudojant vienpusę atsparumo ugniai bandymo metodiką. Bandiniai buvo kaitinami 3 valandas. Tyrimams 
buvo parinkti keturi dažniausiai naudojami užpildai: žvirgždas (frakcija 4/16), dolomito skalda (frakcija 4/16), granito skalda (frakcija 4/16) ir keramzitas (frakcija 4/16) (lengvasis užpildas) ir du skirtingi cementai, cementas be priedų (CEM I 42,5N) ir su $17 \%$ klinties priedu (CEM II/A-LL 42,5N). Betono sudètys pateiktos 2.9 lenteleje. Betono bandinių su cementu be priedų perkaitimo kreivès pateiktos 3.19-3.20 paveiksluose.

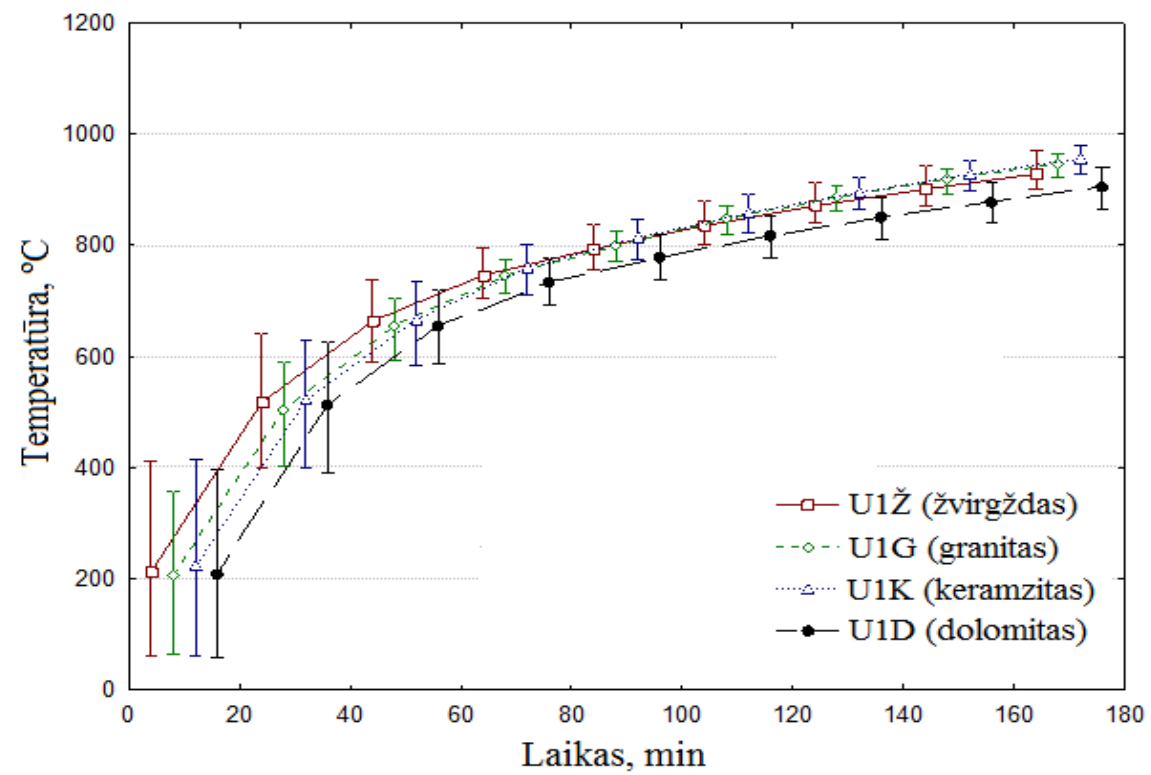

3.19 pav. Temperatūros pasiskirstymas betono bandiniuose su skirtingais užpildais ir CEM I 42,5N cementu $1 \mathrm{~cm}$ atstumu nuo kaitinamo paviršiaus kaitinant vienpusiai

Fig. 3.19. Temperature distribution in concrete samples with different aggregate and CEM I $42,5 \mathrm{~N}$ cement from $1 \mathrm{~cm}$ distance from the heated surface of the one side heating

Bandiniuose su skirtingais užpildais (3.19 pav.), temperatūra laiko bègyje kinta pagal logaritminị dèsnị. Kreivès forma panaši ị standartinio gaisro kreivę. Bandymo pradžioje fiksuojama didesnè duomenų sklaida, bandymo pabaigoje duomenų sklaida sumažèja. Aukščiausia temperatūra iki $700{ }^{\circ} \mathrm{C}$ pasiekiama su žvirgždo užpildu, o mažiausia su dolomito bei keramzito užpildais. Po ilgesnio kaitinimo laiko temperatūros išsilygina išskyrus dolomito užpildą, kuriama temperatūra išlieka mažesnè, negu betone su kitais užpildais. 


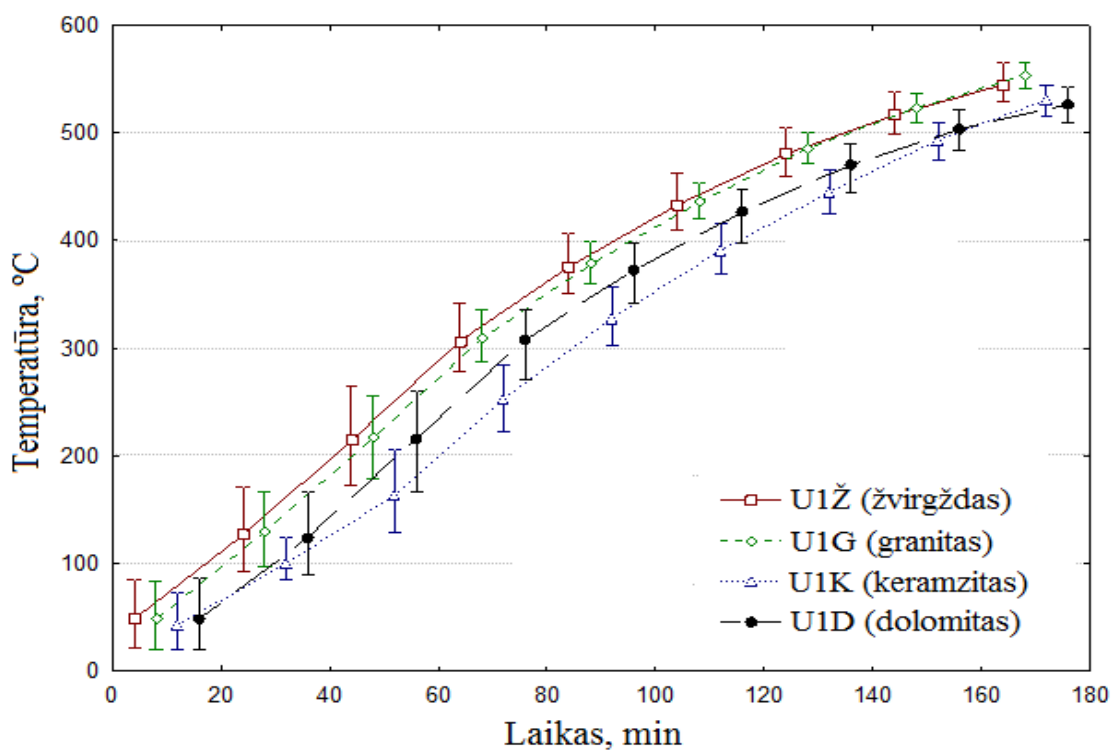

3.20 pav. Temperatūros pasiskirstymas betono bandinyje su skirtingais užpildais ir CEM I 42,5N cementu $5 \mathrm{~cm}$ atstumu nuo kaitinamo paviršiaus kaitinant vienpusiu būdu

Fig. 3.20. Temperature distribution in concrete samples with different fillings and CEM I 42,5 cement from $5 \mathrm{~cm}$ distance from the heated surface of the one side heating

Bandiniuose su skirtingais užpildais $5 \mathrm{~cm}$ atstumu nuo kaitinamo paviršiaus matomas tiesinis temperatūros pasiskirstymą laiko bėgyje. Duomenų sklaida tiek bandymo pradžioje, tiek pabaigoje yra panaši. Aukščiausios temperatūros fiksuojamos betono su žvirgždo ir granito užpildais, žemesnès temperatūros fiksuojamos su dolomito o žemiausios su keramzito užpildais.

Betono bandinių su skirtingais užpildais ir cementu turinčiu $17 \%$ klinties priedo (CEM II/A-LL 42,5N) temperatūros pasiskirstymo kreivès pateikiamos 3.21-3.22 paveiksluose.

Bandiniuose su skirtingais užpildais ir cementu, turinčiu $17 \%$ klinties priedo (3.21 pav.), temperatūra pasiskirsto analogiškai bandiniams su cementu be priedų. Kreivès forma panaši ì standartinio gaisro kreivę. Bandymo pradžioje fiksuojama didesnè duomenų sklaida, bandymo pabaigoje duomenų sklaida sumažèja. Aukščiausia temperatūra iki $700{ }^{\circ} \mathrm{C}$ pasiekiama su žvirgždo užpildu, žemiausia temperatūra pasiekiama su keramzito ir dolomito užpildais. Po ilgesnio kaitinimo laiko temperatūros išsilygina, išskyrus dolomito užpildą, kuriame temperatūra išlieka mažesnè negu betone su kitais užpildais. Panaudojus 
cementą su klinties priedu, temperatūrą $1 \mathrm{~cm}$ atstumu nuo kaitinamo paviršiaus po 3 valandų kaitinimo galima sumažinti nuo $912^{\circ} \mathrm{C}$ iki $873^{\circ} \mathrm{C}$.

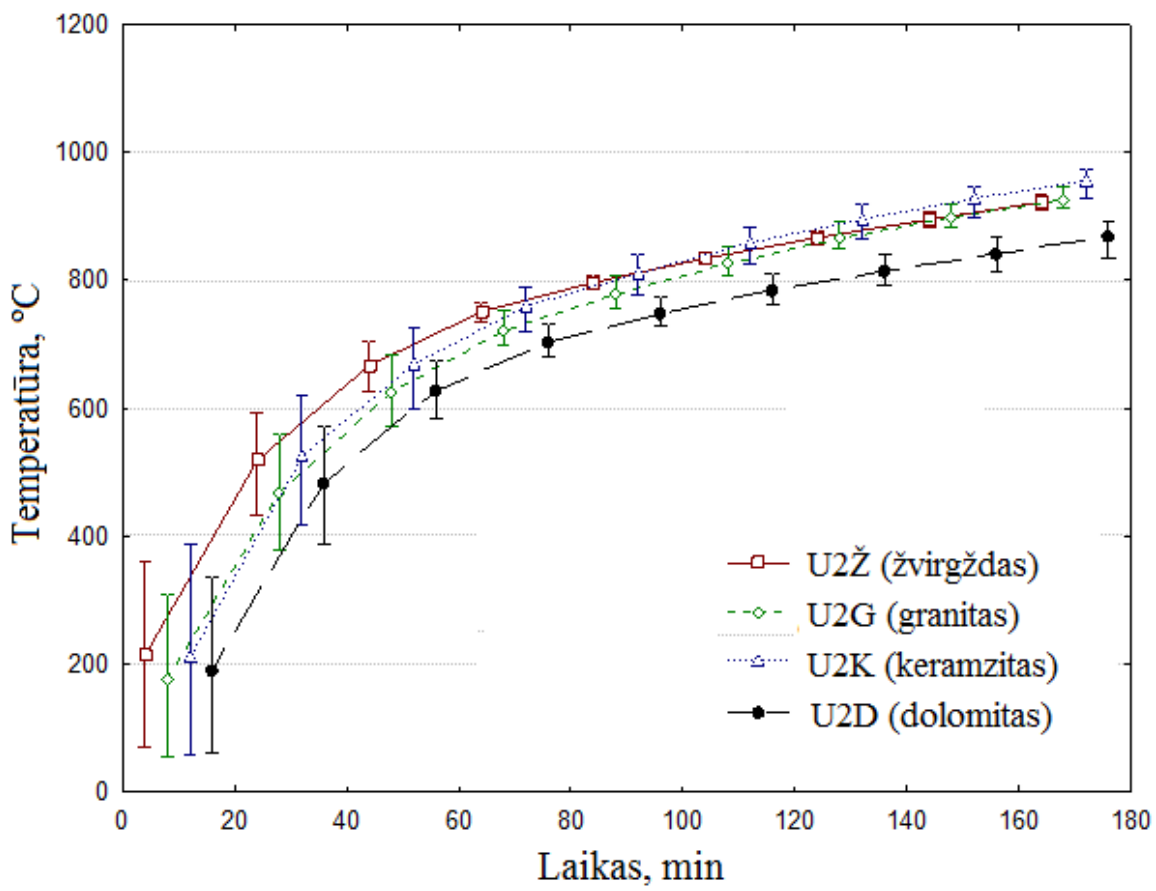

3.21 pav. Temperatūros pasiskirstymas betono bandiniuose su skirtingais užpildais ir CEM II A-LL 42,5N cementu $1 \mathrm{~cm}$ atstumu nuo kaitinamo paviršiaus kaitinant vienpusiu būdu

Fig. 3.21. Temperature distribution in concrete samples with different fillings and CEM II A-LL 42,5N cement from $1 \mathrm{~cm}$ distance from the heated surface of the one side heating

Bandiniuose su skirtingais užpildais ir cementu turinčiu 17 \% klinties priedo nustatant temperatūros pasiskirstymą $5 \mathrm{~cm}$ atstumu nuo kaitinamo paviršiaus (3.22 pav.) gaunamas beveik tiesinis temperatūros pokytis laiko bėgyje. Duomenų sklaida tiek bandymo pradžioje, tiek pabaigoje yra vienoda. Didžiausia temperatūra bandinio centre pasiekiama su žvirgždu, mažiausia temperatūra pasiekiama su keramzito ir dolomito užpildais. Betono su klinties priedu ir dolomitiniu užpildu temperatūra bandinio centre gaunama mažesnè $\left(509{ }^{\circ} \mathrm{C}\right)$ palyginus su bandiniu, kuriame naudotas cementas be priedu $\left(531^{\circ} \mathrm{C}\right)$. 


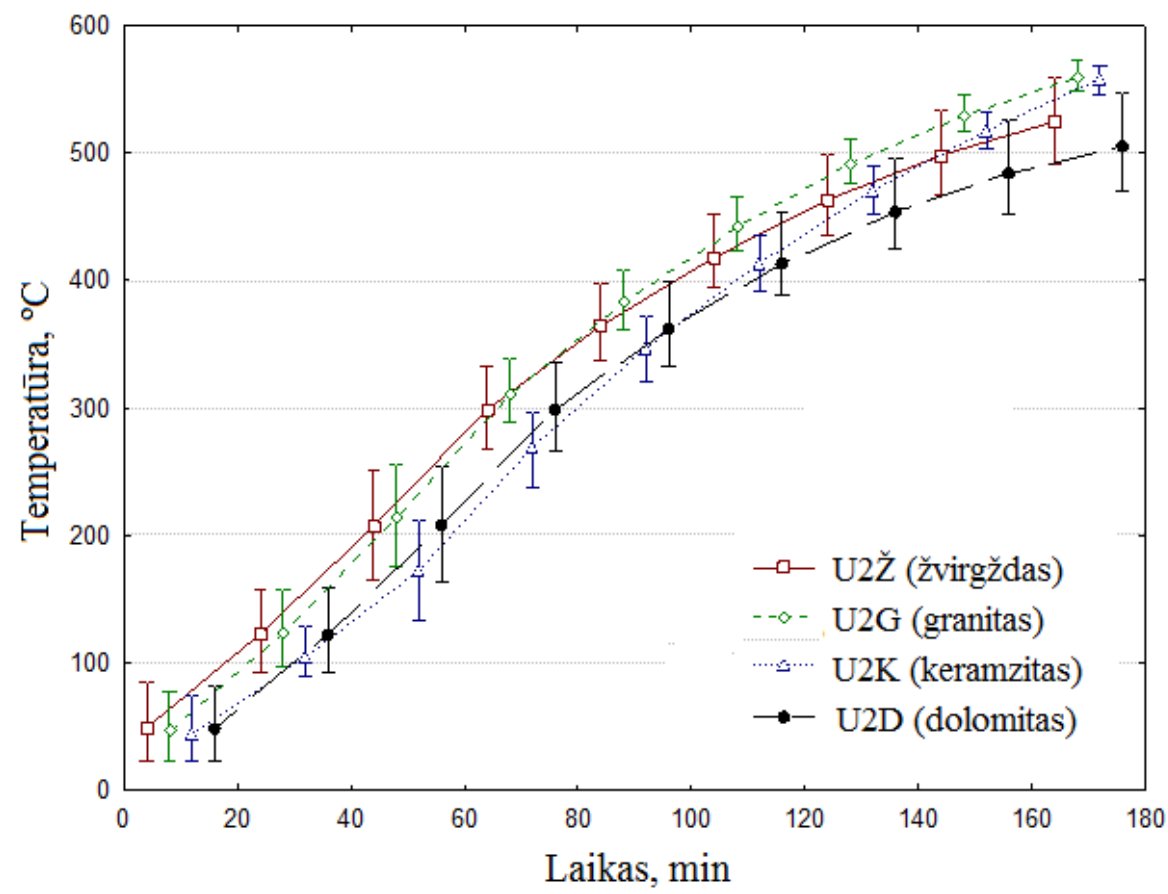

3.22 pav. Temperatūros pasiskirstymas betono bandiniuose su skirtingais užpildais ir

CEM II A-LL 42,5N cementu $5 \mathrm{~cm}$ atstumu nuo kaitinamo paviršiaus kaitinant vienpusiai

Fig. 3.22. Temperature distribution in concrete samples with different fillings and CEM II A-LL 42,5 cement from $5 \mathrm{~cm}$ distance from the heated surface surface of the one side heating

Remiantis gautais rezultatais galima teigti, kad mažiausios temperatūros bandinio paviršiuje, bei bandinio centre pasiekiamos betone, kuriame panaudotas dolomito užpildas. Didžiausia temperatūra bandinio $5 \mathrm{~cm}$ atstume nuo kaitinamo paviršiaus po 3 valandų kaitinimo gauta su betono bandiniais, kuriuose panaudotas dolomito užpildas: su CEM I cementu $5 \mathrm{~cm}$ atstume gauta $531{ }^{\circ} \mathrm{C}$ temperatūra su CEM II A-LL cementu $-509^{\circ} \mathrm{C}$. Didžiausia betono temperatūra $5 \mathrm{~cm}$ atstume su skirtingais užpildais ir CEM I cementu užfiksuota su granito užpildu $-560{ }^{\circ} \mathrm{C}$, su CEM II A-LL cementu užfiksuota taip pat su granito užpildu $-567{ }^{\circ} \mathrm{C}$. 


\subsubsection{Temperatūros pasiskirstymas betone su skirtingais užpildais esant tūriniam temperatūros poveikiui}

Norint ištirti skirtingų užpildų įtaką betono atsparumui ugniai buvo atlikti betono bandinių su skirtingais užpildais tyrimai, panaudojant tūrinio atsparumo ugniai bandymų metodą pagal standartinę gaisro kreivę. Bandiniai buvo kaitinami tris valandas. Tyrimams buvo parinkti keturi dažniausiai naudojami užpildai: žvirgždas, dolomito skalda, granito skalda ir keramzitas. Bandiniai suformuoti su cementu turinčiu 17 \% klinčiu priedo. Betono sudètys pateiktos 2.9 lentelejje. Betono bandinių perkaitimo kreivès pateikiamos 3.23-3.24 paveiksluose.

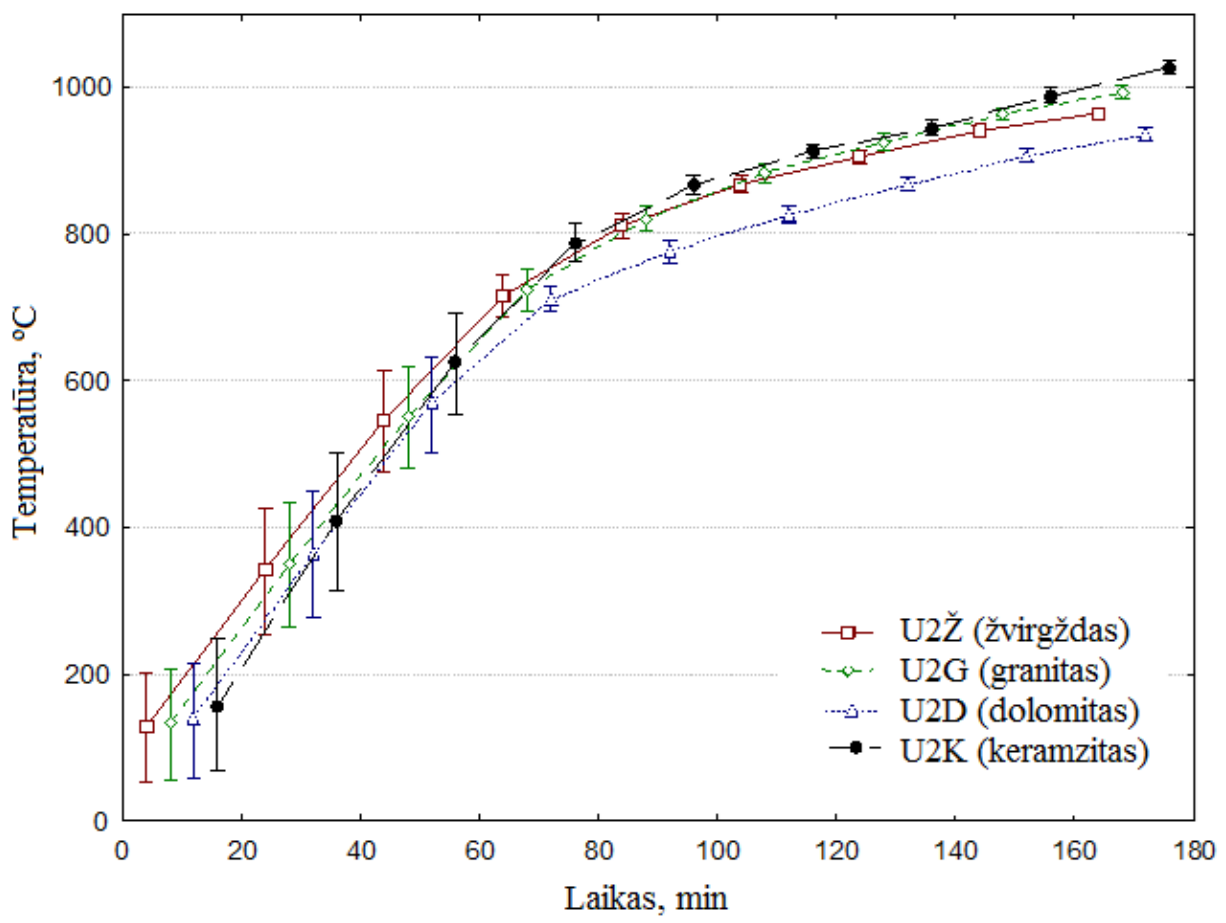

3.23 pav. Temperatūros pasiskirstymas betono bandiniuose su skirtingais užpildais $1 \mathrm{~cm}$ atstumu nuo kaitinamo paviršiaus kaitinant tūriniu būdu

Fig. 3.23. The temperature distribution of the concrete samples with different aggregates $1 \mathrm{~cm}$ distance from the heated surface of the volumetric heating

Betono bandiniuose su skirtingais užpildais (3.23 pav.) $1 \mathrm{~cm}$ atstumu nuo kaitinamo paviršiaus po 3 valandų temperatūra didejja vienodai. Iৃvertinus temperatūros nustatymo paklaidas, galima teigti, kad temperatūros bandinių paviršiuje pasiskirsto vienodai. 
Betono bandiniuose su skirtingais užpildais (3.24 pav.) $5 \mathrm{~cm}$ atstumu nuo kaitinamo paviršiaus iki $600{ }^{\circ} \mathrm{C}$ temperatūros pastebètas beveik vienodas temperatūros augimas o aukštesnèse temperatūrose gaunamas didesnis temperatūros verčių išsibarstymas.

Iš 3.23 ir 3.24 paveiksluose pateiktų kreivių galima matyti, kad naudojant tūrinị kaitinimą 1 ir $5 \mathrm{~cm}$ atstume nuo kaitinamo paviršiaus temperatūros bandiniuose su skirtingais užpildais pasiskirsto nedideliame intervale: $1 \mathrm{~cm}$ atstumu nuo kaitinamo paviršiaus $945-1035^{\circ} \mathrm{C}, 5 \mathrm{~cm}$ atstumu nuo kaitinamo paviršiaus $846-964{ }^{\circ} \mathrm{C}$. Žemiausios temperatūros gautos su dolomito užpildu ir siekè: $1 \mathrm{~cm}$ atstume nuo kaitinamo paviršiaus $945^{\circ} \mathrm{C}, 5 \mathrm{~cm}$ atstumu nuo kaitinamo paviršiaus $846^{\circ} \mathrm{C}$.

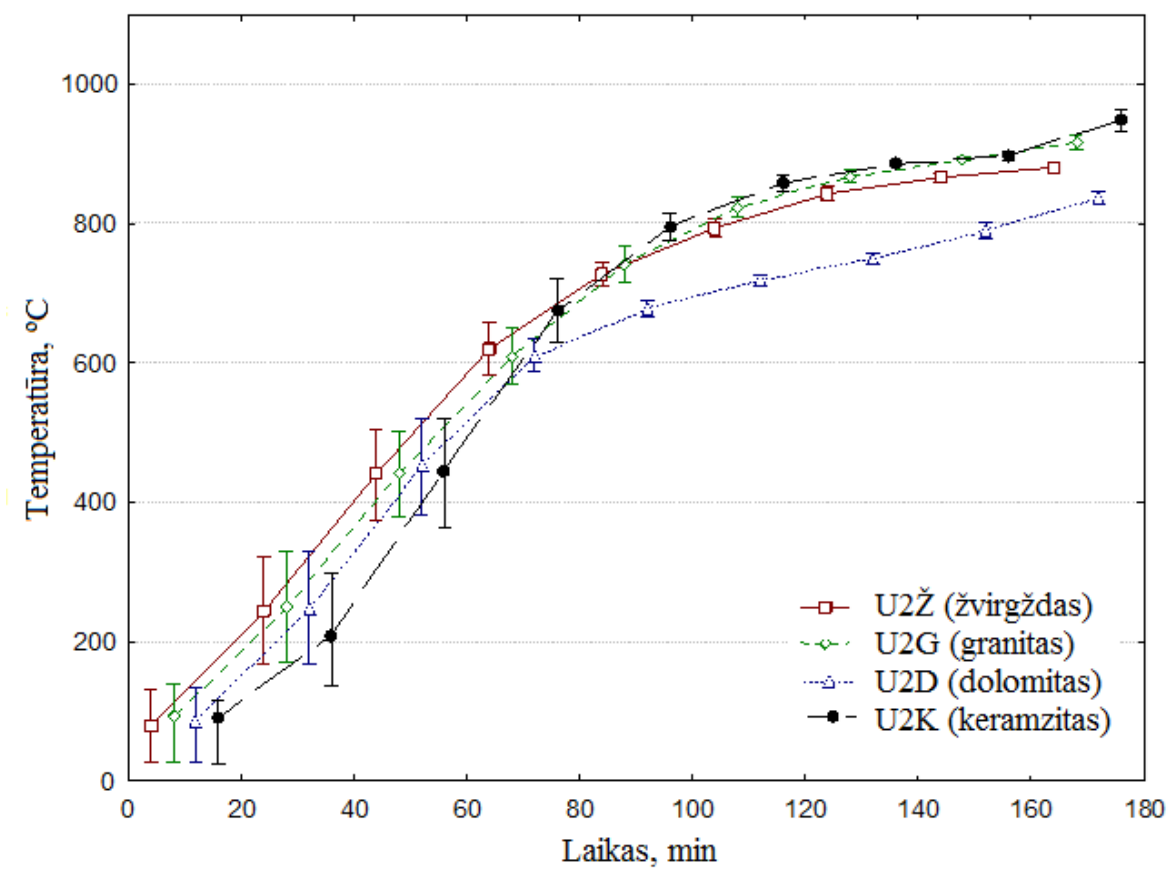

3.24 pav. Temperatūros pasiskirstymas betono bandiniuose su skirtingais užpildais $5 \mathrm{~cm}$ atstume nuo kaitinamo paviršiaus kaitinant tūriniu būdu

Fig. 3.24. The temperature distribution of the concrete samples with different aggregates $5 \mathrm{~cm}$ distance from the heated surface of the volumetric heating

Iš gautų tyrimų rezultatų galima daryti išvadą, kad dolomito užpildas turi teigiamą poveikị atsparumui ugniai lyginant su kitais užpildais, tačiau dèl mažu betono bandinių matmenų tūrinis bandymų metodas yra mažiau tikslus lyginant su vienpusiu kaitinimo metodu. 


\subsubsection{Destrukciniai procesai užpilduose veikiant aukštai temperatūrai}

Siekiant išsiaiškinti skirtingų užpildų ịtaką, buvo atlikti termogravimetriniai tyrimai. Tyrimui pasirinkti penki skirtingi užpildai: keramzitas, dolomitas, smèlis, žvirgždas, granitas. 3.25 paveiksle pateiktos masės nuostolių nuo temperatūros kreivès (TG).

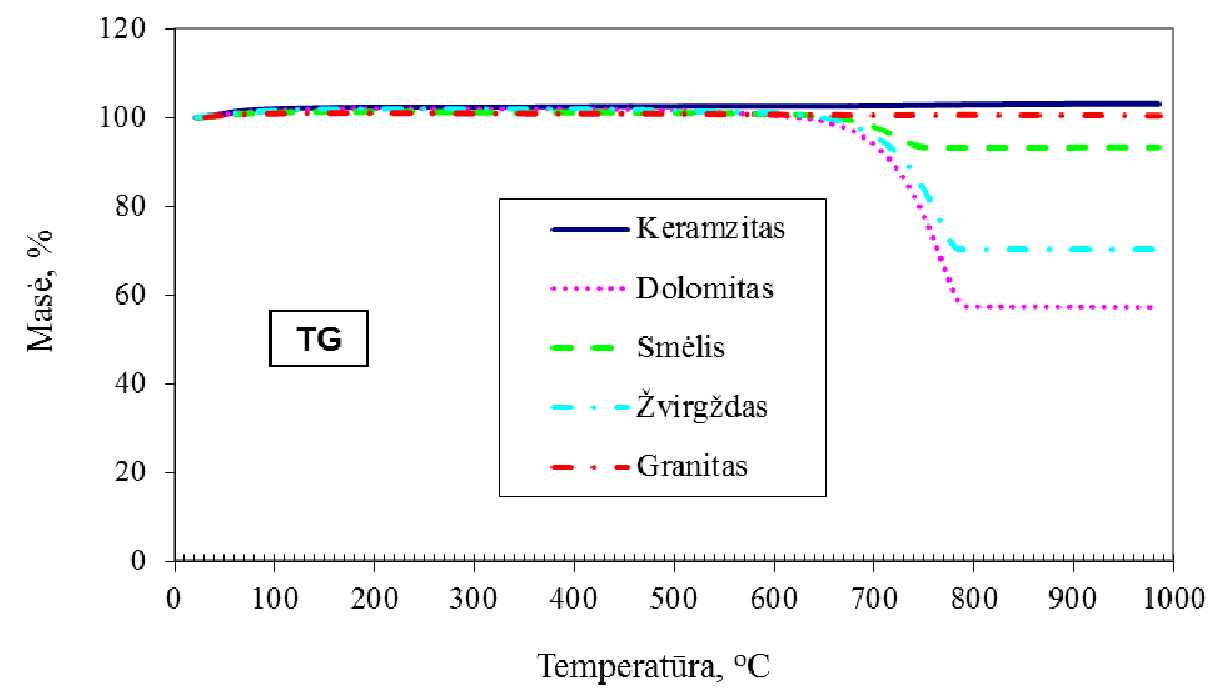

3.25 pav. Skirtingų užpildų termogravimetrinès kreivès

Fig. 3.25. Different types of aggregate termogravimetric curves

Remiantis termogravimetrijos kreivèmis (TG kreivès) galima ịvardinti tokius užpildų skirtumus. Keramzito ir granito užpildai yra inertiški temperatūros poveikiui iki $1000{ }^{\circ} \mathrm{C}$, nes temperatūriniai skilimai neužfiksuoti ir neužfiksuotas masès praradimas. Iš literatūros šaltinių ir gautų TG kreivių galima įvardinti, kad smèlio, žvirgždo ir dolomito užpilduose yra kalcio ir magnio karbonatų, kurie skyla esant $650-800{ }^{\circ} \mathrm{C}$ temperatūrai (Naujokaitis 2006; Balandis et., al. 2004). Didžiausi masès nuostoliai intervale $650-800{ }^{\circ} \mathrm{C}$ užfiksuoti su dolomito užpildu ir siekia $42,5 \%$, su žvirgždo užpildu - 29,7 \%, su smèlio užpildu $6,7 \%$. Todèl galima teigti, kad masès nuostoliu požiūriu tinkamiausi užpildai yra keramzitas ir granitas. Gamtinis smèlis taip pat pasižymi nedideliais masès nuostoliais veikiant aukštai temperatūrai.

Remiantis diferencinès termogravimetrijos rezultatais (DTG kreivemis, 3.26 pav.) masès pokyčiai fiksuojami tik $650-780{ }^{\circ} \mathrm{C}$ temperatūros intervale. Didžiausios masès pokyčiu greičio vertès yra užfiksuotos dolomite ir žvirgžde, 
mažesnès - smèlyje. Visiškai masės pokyčio greitis neužfiksuotas keramzite ir granite.

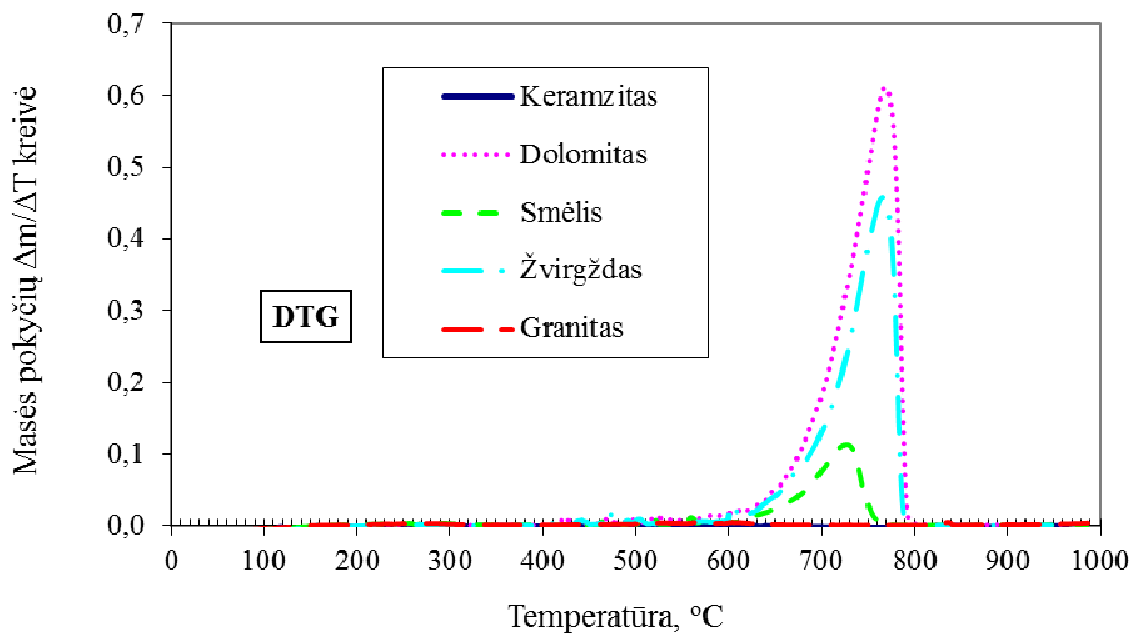

3.26 pav. Skirtingų užpildų diferencinės termogravimetrijos kreivės

Fig. 3.26. Differential termogravimetric curves of different aggregates

3.27 paveiksle pateikiama betono bandinių su skirtingais stambiaisiais užpildais terminio išsiplètimo dilatometrinès kreivès. Betono sudètis pateikta 2.9 lentelèje.

Visiems betono bandiniams būdingas išsiplètimas pasiekus $573{ }^{\circ} \mathrm{C}$ temperatūrą, kadangi visi betonai pagaminti su smulkiuoju užpildu smèliu, kuriame didžiąją dali sudaro kvarco mineralas. Kvarcas prie šios temperatūros keičia kristalinę gardelę iš $\beta$ ị $\alpha$, kas sukelia tūrines deformacijas. Didžiausios deformacijos minètoje temperatūroje pastebètos betone su granito stambiuoju užpil$\mathrm{du}$, kuriame yra papildomas kiekis kvarco.

Bendrosios deformacijos betono su skirtingais užpildais yra didžiausios naudojant žvirgždo užpildą, kurios siekia apie $1,0 \%$, su granito užpildu siekia $0,8 \%$, su dolomito užpildu siekia $0,4 \%$ o mažiausios deformacijos užfiksuotos su keramzito užpildu, kurios siekia $0,2 \%$. Todèl tinkamiausi ugniai atsparumo požiūriu betono stambieji užpildai yra keramzitas (lengvajam betonui) ir dolomitas. 


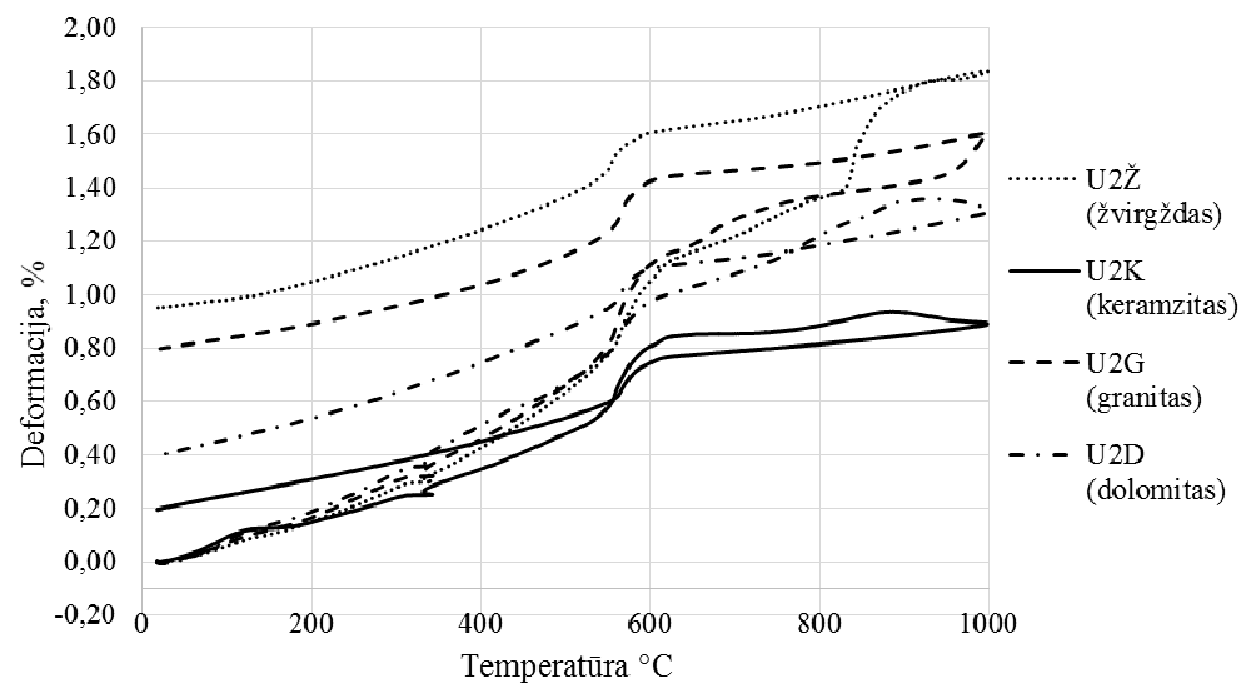

3.27 pav. Betono bandinių su skirtingais užpildais terminis išsiplètimas ir susitraukimas

Fig. 3.27. Thermal expansion and shrinkage of concrete samples with different aggregates

Didžiausias plètimasis kaitinant užfiksuotas betono bandiniuose su žvirgždo užpildu ir siekia apie $1,8 \%$, tačiau vykstant bandinio aušinimui betono bandinys traukiasi ir pasiekia 1,0 \% reikšmę. Mažiausias betono bandinių plètimasis užfiksuotas su keramzito užpildu ir siekia $0,8 \%$ ribą, vèstant bandiniui išsiplètimas mažèja ir pasiekia apie $0,2 \%$ ribą. Šie skirtumai aiškinami keramzito užpildo mineraline sudètimi ir jo terminiu inertiškumu. Betono su dolomito užpildu terminis išsiplètimas siekia $1,4 \%$, atvèsus bandinys pasiekia $0,4 \%$ ribą, tai daro mažesnę įtaka betono destrukciniams procesams lyginant su kitais sunkiaisiais užpildais.

\subsubsection{Užpildo mineralinės sudèties ịtaka betono savybių pokyčiams veikiant aukštai temperatūrai}

Betono su stambiaisiais užpildais masès nuostolių vertès po 3 valandų kaitinimo pateiktos 3.4 lentelèje. Betono masès nuostoliu po kaitinimo rezultatai rodo, kad su visais užpildais gaunami panašūs masès nuostoliai (nuo 6,7 \% iki $9,6 \%$ su cementu be mineraliniu priedų ir nuo 7,0 \% iki 10,0\% su cementu su klinties priedu), išskyrus granito užpildą, kuris duoda masès nuostolius 5,3\% ir $6,0 \%$ atitinkamai cementu be priedu ir su klinties priedu. Rezultatai rodo, kad 
granito stambusis užpildas, sukelia mažiausius masès nuostolius betone veikiant aukštai temperatūrai.

3.4 lentelè. Betono bandinių su skirtingais užpildais masès nuostoliai po kaitinimo Table 3.4. Concrete samples with different fillings weight loss after heating

\begin{tabular}{|c|c|c|}
\hline \multirow{2}{*}{ Sudetties žymuo } & \multicolumn{2}{|c|}{$\begin{array}{c}\text { Masės nuostoliai po 3 val. kaitinimo, kai cemento tipai } \\
\text { skirtingi, \% }\end{array}$} \\
\cline { 2 - 3 } & CEM I 42,5N & CEM II/A-LL 42,5N \\
\hline U2Ž (žvirgždas) & 6,67 & 7,04 \\
\hline U2D (dolomitas) & 9,32 & 9,20 \\
\hline U2G (granitas) & 5,33 & 5,98 \\
\hline U2K (keramzitas) & 9,61 & 9,95 \\
\hline
\end{tabular}

Ultragarso sklidimo greičio sumažèjimas po vienpusio kaitinimo betonuose su skirtingais užpildais pateiktas 3.5 lentelejje.

3.5 lentelè. Ultragarso sklidimo greitis betono bandiniuose su skirtingais užpildais ir skirtingais cemento tipais

Table 3.5. Ultrasonic velocity of concrete samples with different aggregates and different types of cement

\begin{tabular}{|c|c|c|c|}
\hline Sudėties žymuo & $\begin{array}{c}\text { Ultragarso sklidimo } \\
\text { greitis prieš kaitini- } \\
\text { mą, m/s }\end{array}$ & $\begin{array}{c}\text { Ultragarso sklidimo } \\
\text { greitis po 3 val. } \\
\text { kaitinimo, m/s }\end{array}$ & $\begin{array}{c}\text { Ultragarso skli- } \\
\text { dimo greičio } \\
\text { sumažejimas, \% }\end{array}$ \\
\hline U1Ž (žvirgždas) & 4826 & 1327 & 75,5 \\
\hline U2Ž (žvirgždas) & 4809 & 1364 & 71,6 \\
\hline U1D (dolomitas) & 4926 & 1164 & 76,4 \\
\hline U2D (dolomitas) & 4828 & 1645 & 65,9 \\
\hline U1G (granitas) & 4891 & 1200 & 75,5 \\
\hline U2G (granitas) & 4800 & 1067 & 77,8 \\
\hline U1K (keramzitas) & 3929 & 1526 & 61,2 \\
\hline U2K (keramzitas) & 3863 & 1501 & 61,1 \\
\hline
\end{tabular}

Suformuotose betono bandiniuose su skirtingais užpildais, ultragarsas greičiausiai sklinda su dolomito užpildu ir siekia $4926 \mathrm{~m} / \mathrm{s}$. Mažiausias sklidimo greitis užfiksuotas betone su keramzito užpildu ir siekia $3863 \mathrm{~m} / \mathrm{s}$. Paveikus betono bandinius temperatūra 3 valandas iš vienos pusès pagal standartinę gaisro kreivę, didžiausias ultragarso sklidimo greičio sumažejimas gautas su 17 \% klinčių priedo turinčiu cementu ir granito užpildu, pokytis siekia 77,8 \%. Mažiausiai pakinta betono bandiniai su keramzito užpildu jie siekia $61,1 \%$ ir su dolomito užpildu 65,9 \%. Užfiksuoti mažiausi pokyčiai gali būti aiškinami keramzito terminiu inertiškumu ir didelèmis granito užpildo deformacijomis veikiant aukštai temperatūrai. 
Betonų su cementu be priedų ir skirtingais stambiaisiais užpildais (žvirgždu, dolomitu, granitu) ultragarso sklidimo greitis po kaitinimo sumažeja beveik vienodai - apie $76 \%$, o su cementu su klinties priedu mažiausias sumažèjimas gaunamas su dolomito užpildu ir siekia $66 \%$. Remiantis gautais ultragarso sklidimo greičio sumažejimo rezultatais galima teigti, kad tinkamiausias stambusis užpildas normaliajam betonui yra dolomitas.

Betono su skirtingais stambiaisiais užpildais gniuždymo stipris pateiktas 3.6 lentelèje, gniuždymo stiprio sumažèjimas po 3 val. temperatūrinio poveikio pagal standartinę gaisro kreivę pateiktas 3.28 paveiksle (su cementu be priedų) ir 3.29 paveiksle (su cementu kuriame yra $17 \%$ klinties priedo).

3.6 lentelè. Betono bandinių gniuždymo stipris su skirtingais užpildais prieš kaitinimą ir po 3 val. temperatūrinio poveikio

Table 3.6. Concrete samples compressive strength with different aggregate before heating and after 3 hours heating

\begin{tabular}{|c|c|c|}
\hline Sudėties žymuo & $\begin{array}{c}\text { Gniuždymo stipris prieš } \\
\text { kaitinimą, MPa }\end{array}$ & $\begin{array}{c}\text { Gniuždymo stipris po 3 val. } \\
\text { kaitinimo, MPa }\end{array}$ \\
\hline U1Ž (žvirgždas) & 59,2 & 33,5 \\
\hline U1D (dolomitas) & 59,7 & 33,6 \\
\hline U1G (granitas) & 67,8 & 34,1 \\
\hline U1K (keramzitas) & 20,1 & 14,9 \\
\hline U2Ž (žvirgždas) & 63,0 & 33,8 \\
\hline U2D (dolomitas) & 57,3 & 32,4 \\
\hline U2G (granitas) & 61,5 & 32,5 \\
\hline U2K (keramzitas) & 15,9 & 12,0 \\
\hline
\end{tabular}

Betono bandinių su skirtingais užpildais gniuždymo stipris skiriasi. Gauti rezultatai rodo, kad didžiausią gniuždymo stiprị turi bandiniai su CEM I 42,5R cementu ir granito užpildu $(67,8 \mathrm{MPa})$, mažiausias gniuždymo stipris užfiksuotas su CEM II/A-LL 42,5N cementu ir keramzito užpildu (lengvajam betonui) (15,9 MPa).

Iš gautų rezultatų, kurie pateikti 3.28 paveiksle, galima pastebèti, kad žymiai mažesnis gniuždymo stiprio sumažejimas yra užfiksuotas su keramzito stambiuoju užpildu, kuris siekia $25 \%$. Su sunkiaisiais užpildais (žvirgždas, dolomitas, granitas) didžiausias gniuždymo stiprio sumažejimas gaunamas su granito užpildu ir siekia $49,7 \%$ su cementu be priedu ir $47,1 \%$ su cementu su $17 \%$ klinties priedu. Normaliujų betonų su žvirgždo skalda stiprumo sumažèjimas siekia 43,4 \% su cementu be priedų ir 46,3\% su cementu su klinties priedu. Mažiausias gniuždymo stiprio sumažejimas gaunamas su dolomito už- 
pildu jis siekia 43,7\% su cementu be priedų ir 43,4\% su cementu su klinties priedu.
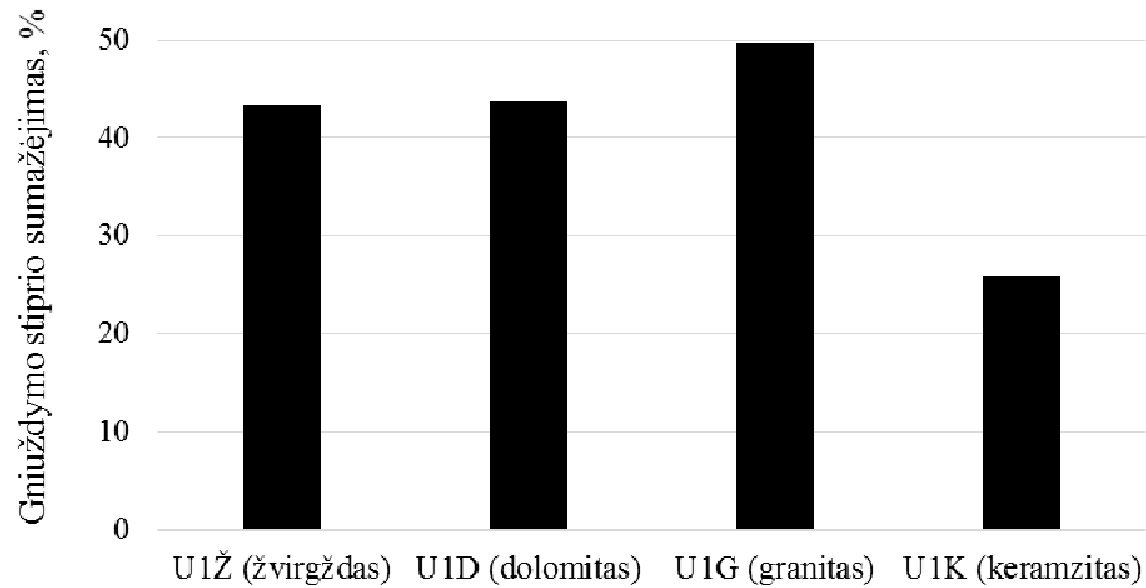

3.28 pav. Betono bandinių su cementu be priedų ir skirtingais užpildais gniuždymo stiprio sumažèjimas

Fig. 3.28. Concrete samples compressive strength decrease with cement without additives and different aggregates

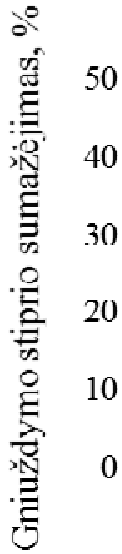

50

0
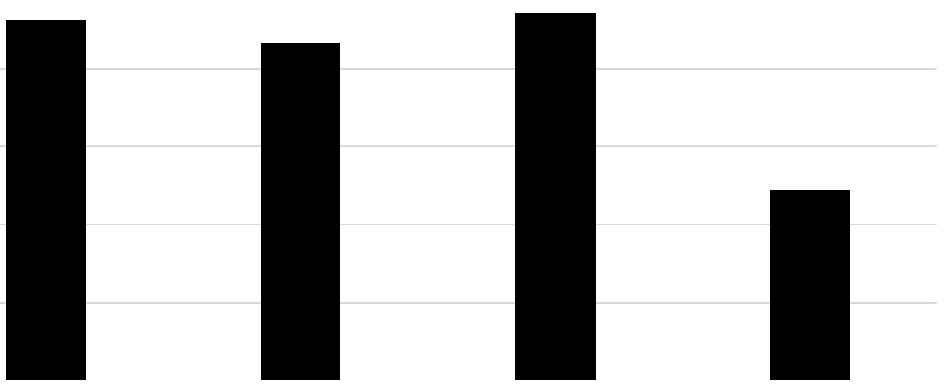

U2Ž (Žvirgždas) U2D (dolomitas) U2G (granitas) U2K (keramzitas)

3.29 pav. Betono bandinių su cementu su $17 \%$ klinties priedu ir skirtingais užpildais gniuždymo stiprio sumažejjimas

Fig. 3.29. Concrete samples compressive strength decrease with cement with $17 \%$ limestone additive and different aggregates 
Tyrimų rezultatai rodo, kad tinkamiausias atsparumo ugniai požiūriu sunkusis užpildas yra dolomitas, kurio stiprumo sumažèjimas yra mažiausias. Granito sunkusis užpildas netinkamas naudoti atsparumo ugniai požiūriu betonuose, nes su šiuo užpildu betono stiprumo sumažejjimas yra didžiausias.

\subsection{Itraukto oro kiekio ịtaka betono atsparumui ugniai}

\subsubsection{Temperatūros pasiskirstymas betone su skirtingu oro kiekiu esant vienpusiam temperatūros poveikiui}

Oro kiekio betono mišinyje matavimai atlikti pagal standartinę bandymo metodiką LST EN 12350-7 (naudojant slègini metodą) pateikti 3.7 lentelèje. Didinant orą įtraukiančios įmaišos kieki iki $0,6 \%$, oro kiekis betono mišinyje didèjo nuo 3,2 \% iki 14,0 \%. Didejjant oro kiekiui betono mišinyje suketejusio betono stiprumas nežymiai mažeja, todèl norint gauti analogišką betono stiprumą su dideliu oro kiekiu (apie 10-14 \%) buvo padidintas cemento kiekis ir sumažintas V/C santykis. Betono sudètys pateiktos 2.10 lentelèje.

3.7 lentelè. Itraukto oro kiekio betono mišinyje bandymų rezultatai

Table 3.7. Test rezults of entrained air in concreat mixture

\begin{tabular}{|c|c|c|}
\hline Sudèties žymuo, \% & $\begin{array}{l}\text { Orą itraukiančios } \\
\text { imaišos kiekis, \% }\end{array}$ & $\begin{array}{l}\text { Itraukto oro kiekis } \\
\text { betono mišinyje, \% }\end{array}$ \\
\hline O (itraukto oro 3,2 \%) & 0 & 3,2 \\
\hline O-01 (itraukto oro $4,0 \%$ ) & 0,1 & 4,0 \\
\hline O-02 (itraukto oro 5,0 \%) & 0,2 & 5,0 \\
\hline O-03(itraukto oro $10,0 \%$ ) & 0,3 & 10,0 \\
\hline O-06 (itraukto oro $14,0 \%$ ) & 0,6 & 14,0 \\
\hline O-03P (itraukto oro 8,5 \%) & 0,3 & 8,5 \\
\hline O-06P (itraukto oro $12,0 \%$ ) & 0,6 & 12,0 \\
\hline
\end{tabular}

Sukietejusio betono su 3,2\%, 5,0 \%, 14,0 \% įtraukto oro kiekiu mikrostruktūros nuotraukos (didinimas 50-100 kartų) pateiktos 3.30 paveiksle.

Iš pateikto 3.30 paveikslo galima matyti betono bandiniu su skirtingu itrauktu oro kiekiu skelto paviršiaus mikrostruktūrą, kuri skiriasi: a) nuotraukoje uždarų oro porų kiekis nedidelis 1-2 vnt. $90 \mathrm{~mm}^{2}$ plote, b) nuotraukoje uždarų 
oro porų kiekis didesnis apie 6 vnt. $90 \mathrm{~mm}^{2}$ plote, c) nuotraukoje uždarų oro porų kiekis didelis - apie $10 \mathrm{vnt} .90 \mathrm{~mm}^{2}$ plote.

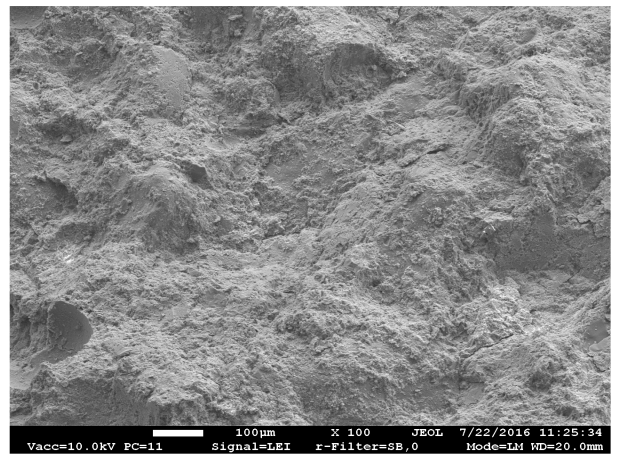

a)

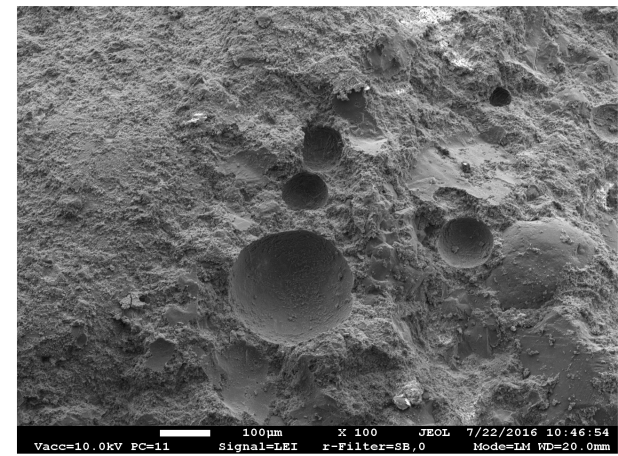

b)

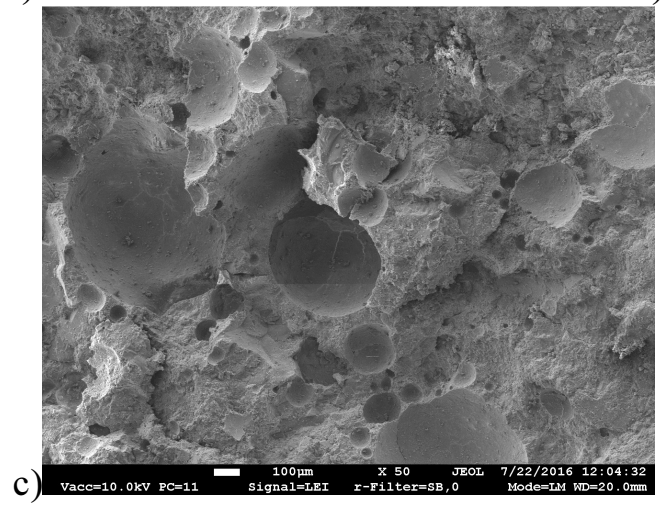

3.30 pav. Betono bandinių skelto paviršiaus mikrostruktūros nuotraukos: a) $\mathrm{O}$ (itraukto oro 3,2 \%); b) O-02 (itraukto oro 5,0 \%); c) O-06 (itraukto oro 14,0\%)

Fig. 3.30. Concrete samples of splited surface microstructure photos:

a) $\mathrm{O}$ (3.2\% entrained air); b) O-02 (5.0\% entrained air); c) O-06 (14.0\% entrained air)

Temperatūros pasiskirstymo skirtinguose betono sluoksniuose tyrimams, buvo naudojami betonai turintys skirtingą oro kiekị. Tyrimai atliekami pagal tą pačią vienpusio kaitinimo metodiką. Ištirti betonai, kurių oro kiekiai yra: $3,2 \%, 4 \%, 5 \%, 10 \%, 14 \%$, imaišant orą itraukiančios įmaišos kiekị atitinkamai: $0 \%, 0,1 \%, 0,2 \%, 0,3 \%, 0,6 \%$. Papildomai buvo atlikti bandymai su padidintu cemento kiekiu tam, kad išlaikyti tą pati betono stiprumą padidèjus oro kiekiui jame. Sumaišius betono mišini su $0,3 \%$ itraukiančios įmaišos kiekiu, buvo gautas oro kiekis betone $8,5 \%$; su $0,6 \%$ įmaiša buvo gautas oro kiekis $12 \%$. Betono sudètys pateiktos 2.10 lentelèje. Betono bandinių temperatūros pasiskirstymo kreivès su CEM II/A-LL 42,5N tipo cementu, dolomito užpildu ir skirtingu oro kiekiu pateikiamos 3.31-3.32 paveiksluose. 
Betono bandiniuose su skirtingu oro kiekiu, temperatūra kyla pagal logaritminị dèsnị. Kreivès forma panaši ị standartinio gaisro kreivę. Bandymo pradžioje fiksuojama didesnè duomenų sklaida, bandymo pabaigoje duomenų sklaida sumažèja. Iki $700{ }^{\circ} \mathrm{C}$ temperatūros aukščiausia temperatūra $1 \mathrm{~cm}$ atstumu nuo kaitinamo paviršiaus gaunama betone be orą įtraukiančios įmaišos (sudèties žymuo O) su savaime ịtrauktu oro kiekiu 3,2 \%. Mažiausia temperatūra $1 \mathrm{~cm}$ atstumu nuo kaitinamo paviršiaus gaunama su $5 \%$ įtraukto oro kiekiu, gaunamu panaudojus $0,2 \%$ įmaišos nuo cemento kiekio. Aukščiau $700{ }^{\circ} \mathrm{C}$ temperatūros $1 \mathrm{~cm}$ atstumu nuo paviršiaus temperatūra bandiniuose su skirtingu oro kiekiu susivienodina, tačiau betone su $5 \%$ ji išlieka mažesnè.

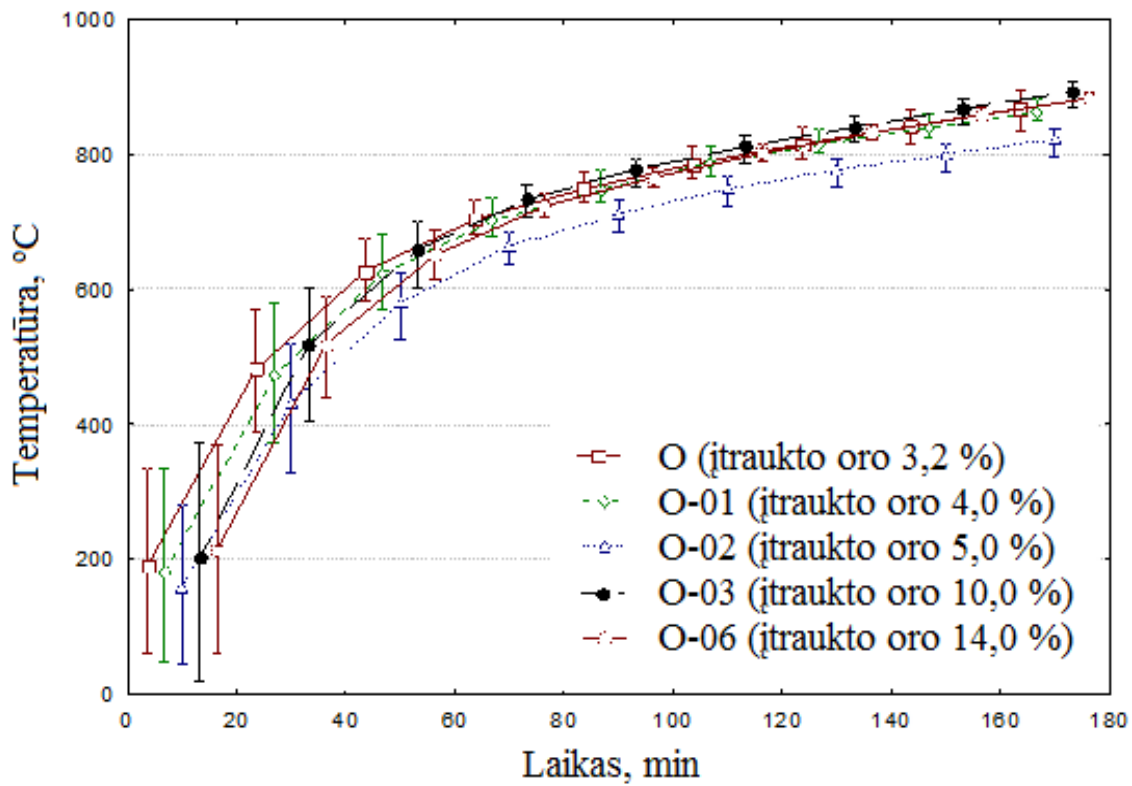

3.31 pav. Temperatūros pasiskirstymas betono bandiniuose su skirtingais oro kiekiais $1 \mathrm{~cm}$ atstumu nuo kaitinamo paviršiaus kaitinant vienpusiu būdu

Fig. 3.31. Temperature distribution in concrete samples with different amount of air $1 \mathrm{~cm}$ from the heated surface of the one side heating

Aukščiausia temperatūra po 3 valandų kaitinimo pasiekiama betono bandinyje su $10 \%$ oro kiekiu ir siekia $893{ }^{\circ} \mathrm{C}$. Toliau išsidèsto bandiniai su $4 \%$ ir $14 \%$ oro kiekiu $-871{ }^{\circ} \mathrm{C}$, su padidintu cemento kiekiu $-8,5 \%$ ir $12 \%$ oro kiekiu $-853{ }^{\circ} \mathrm{C}$. Mažiausia temperatūra pasiekiama su $5 \%$ oro kiekiu ir siekia $820^{\circ} \mathrm{C}$. 
Bandiniuose su skirtingu oro kiekiu nustatant temperatūros pasiskirstymą $5 \mathrm{~cm}$ atstumu nuo kaitinamo paviršiaus (3.32 pav.) matomas beveik tiesinis temperatūros kitimas laiko bėgyje. Maksimalios temperatūros betonuose su orą įtraukiančia įmaiša ir oro kiekiu $4,0-14,0 \%$ po 3 valandų kaitinimo išsidèsto mažame intervale nuo $470{ }^{\circ} \mathrm{C}$ iki $478{ }^{\circ} \mathrm{C}$. Tuo tarpu betone be orą įtraukiančios imaišos su 3,2 \% oro kiekiu ši temperatūra yra didesnè ir siekia $505{ }^{\circ} \mathrm{C}$ temperatūrą.

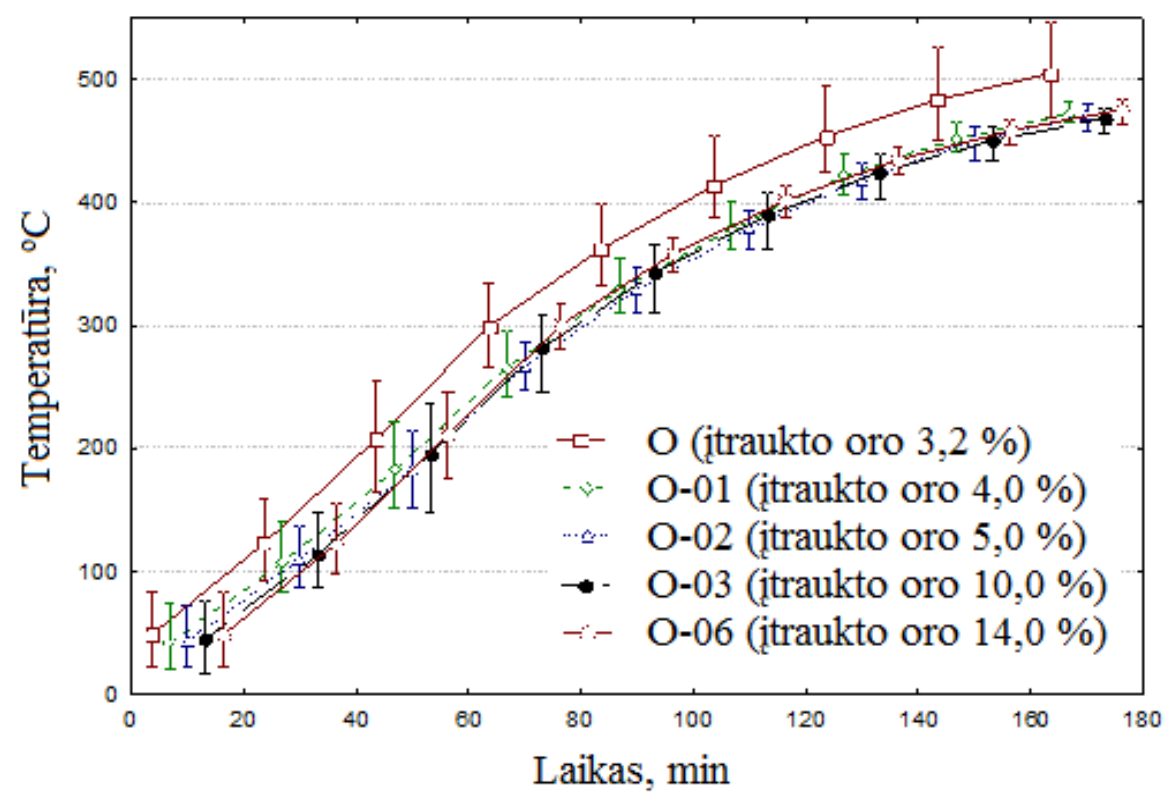

3.32 pav. Temperatūros pasiskirstymas betono bandiniuose su skirtingais oro kiekiais $5 \mathrm{~cm}$ atstumu nuo kaitinamo paviršiaus kaitinant vienpusiai

Fig. 3.32. Temperature distribution in concrete samples with different amount of air $5 \mathrm{~cm}$ from the heated surface of the one side heating

Tyrimų rezultatai rodo, kad padidinus oro kieki betone iki 4,0-5,0 \% betono temperatūra po kaitinimo vidiniuose sluoksniuose gali būti sumažinta daugiau nei $30^{\circ} \mathrm{C}$.

\subsubsection{Oro kiekio ịtaka betono savybių pokyčiams veikiant aukštai temperatūrai}

Betono su skirtingu oro kiekiu dilatometrinès kreivès iki $1000{ }^{\circ} \mathrm{C}$ temperatūros pateiktos 3.33 paveiksle. Betono sudètys pateiktos 2.10 lentelèje. 


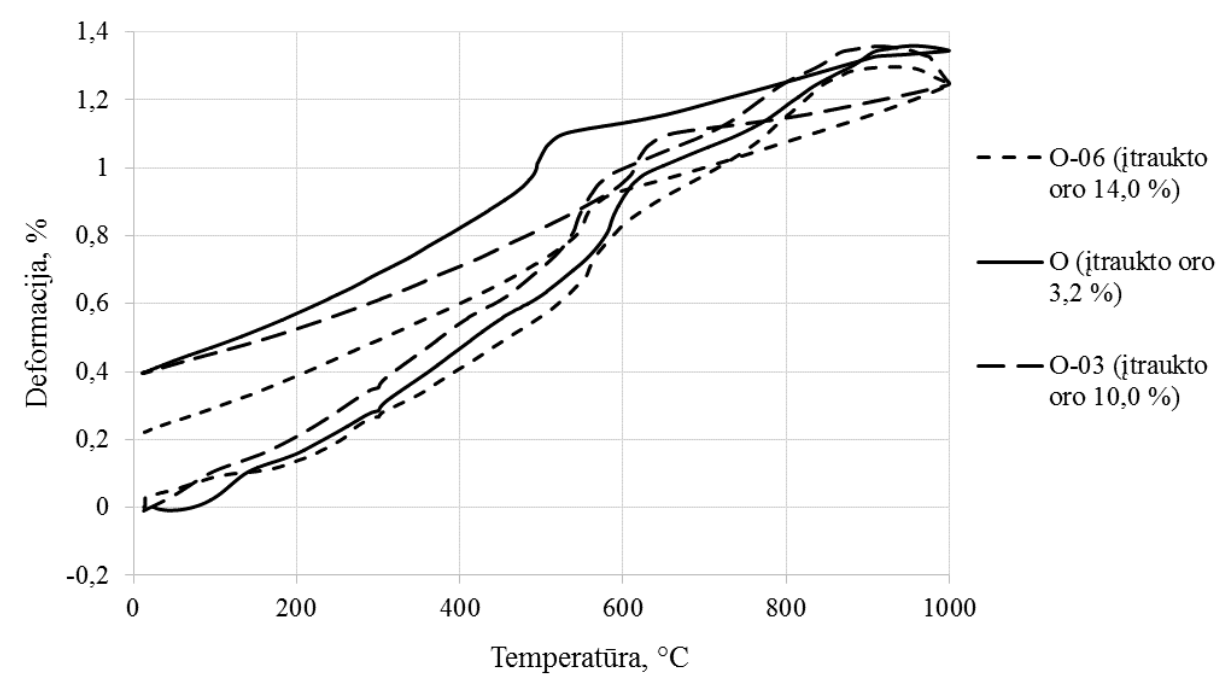

3.33 pav. Betono bandinių su skirtingais oro kiekiais terminis išsiplètimas ir susitraukimas

Fig. 3.33. Thermal expansion of concrete samples with different amount of air

3.33 paveiksle pateiktose dilatometrinèse kreivėse pastebètas žymus bandinių tūrio padidejimas prie $573{ }^{\circ} \mathrm{C}$ temperatūros, kuriame vyksta kvarco persikristalizavimo procesai. Didžiausias plètimasis kaitinant užfiksuotas betono bandiniuose su mažiausiu oro kiekiu betone, t. y. 3,2\%, deformacija siekia $1,6 \%$ ribą. Mažiausios deformacijos užfiksuotos su didžiausiu oro kiekiu betone ir siekia apie $1,3 \%$ ribą. Vèstant bandiniui pastebima ta pati tendencija, su mažu oro kiekiu liekamoji deformacija yra $0,6 \%$, su didžiausiu oro kiekiu liekamoji deformacija siekia $0,2 \%$. Ši liekamoji deformacija yra du kartus mažesne lyginant su kitais tirtais betonais. Betono deformacijų sumažejjimą kaitinant galima paaiškinti didesniu oro tūriu, kuris kompensuoja susidarančius vidinius įtempius.

Betono su skirtingais itraukto oro kiekiais masès nuostoliai po 3 valandų kaitinimo pateikti 3.34 paveiksle. Betono sudètys pateiktos 2.10 lentelèje.

Iš 3.34 paveikslo matyti, kad betono masès nuostoliai nežymiai mažèja nuo 9,2 \% iki 8,6 \% didejjant oro kiekiui nuo 3,2 \% (betonas be orą įtraukiančios įmaišos) iki $14 \%$ (su $0,6 \%$ orą itraukiančios įmaišos). Gauti rezultatai rodo, kad oro kiekio didinimas betono mišinyje nežymiai sumažina masès nuostolius po kaitinimo. 


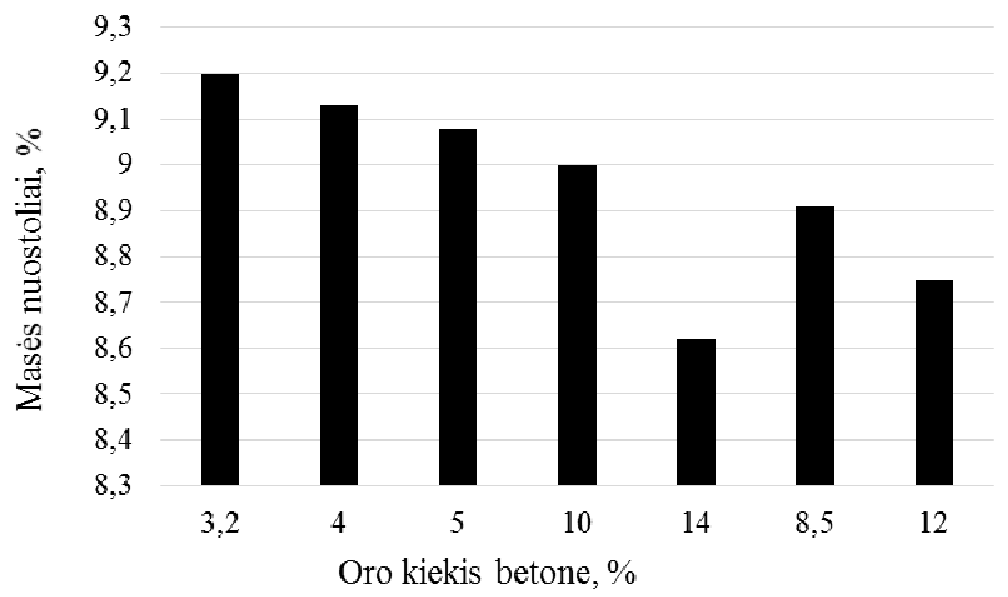

3.34 pav. Betono bandinių su $17 \%$ klinties priedo turinčiu cementu, dolomito užpildu ir su skirtingu oro kiekiu masès nuostoliai po trijų valandų kaitinimo vienpusiu būdu

Fig. 3.34. Weight loss in concrete samples with $17 \%$ limestone additive, dolomite aggregate and different amounts of air after three hours of heating of the one side heating

Betono ultragarso sklidimo greičio priklausomybè nuo įtraukto oro kiekio betone pateikta 3.35 paveiksle. Betono sudètys pateiktos 2.10 lentelèje.

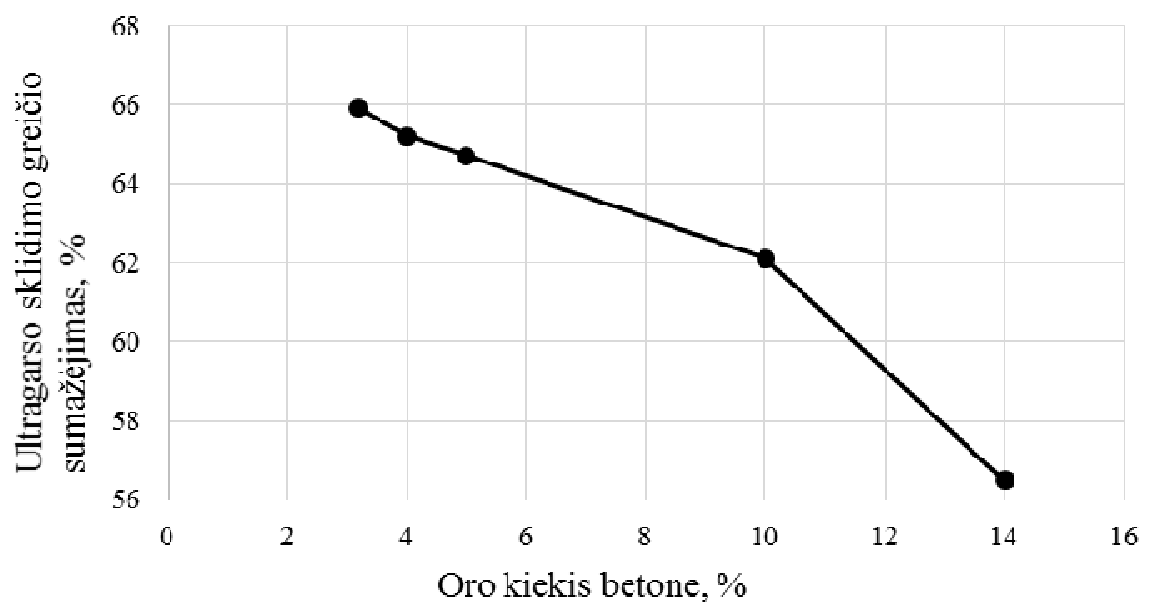

3.35 pav. Ultragarso sklidimo greičio sumažejjimo priklausomybė nuo oro kiekio betone (17\% klinčių priedas, dolomito užpildas) po 3 val. kaitinimo vienpusiu būdu

Fig. 3.35. Ultrasonic velocity decrease dependence of air volume in concrete (17\% limestone additive, dolomite aggregate) after $3 \mathrm{~h}$. of one side heating 
Suformuotose betono bandiniuose su skirtingais oro kiekiais, ultragarsas greičiausiai sklinda betono bandinyje su $3,2 \%$ oro kiekiu, o mažiausias ultragarso sklidimo greitis užfiksuotas su $14 \%$ oro kiekiu betone. Tai gali būti paaiškinama per cementini akmenị didesniu greičiu perduodamu ultragarso impulsu, negu per oro poras. Kuo didesnis cementinio akmens kiekis betone, tuo didesnis ultragarso sklidimo greitis. Paveikus betono bandinius su skirtingais oro kiekiais pagal standartinę gaisro kreivę gauti tokie rezultatai. Ultragarso greičio sumažèjimas betone tiesiškai mažèja didejjant itraukto oro kiekiui. Jis siekia $65,9 \%$, kai oro kiekis $3,2 \%$ ir $56,5 \%$, kai oro kiekis $14 \%$.

Betono su skirtingu oro kiekiu, bei padidintu cemento kiekiu mišiniuose gniuždymo stiprio rezultatai pateikti 3.8 lentelèje, gniuždymo stiprio sumažèjimo priklausomybè nuo įtraukto oro kiekio betone pateiktas 3.36 paveiksle.

3.8 lentelè. Betono bandinių gniuždymo stipris su skirtingais oro kiekiais

Table 3.8. Compressive strength of concrete samples with different amount of air

\begin{tabular}{|c|c|c|}
\hline Sudeties žymuo, \% & $\begin{array}{c}\text { Gniuždymo stipris } \\
\text { prieš kaitinimą, MPa }\end{array}$ & $\begin{array}{c}\text { Gniuždymo stipris po 3 } \\
\text { val. kaitinimo, MPa }\end{array}$ \\
\hline O (itraukto oro 3,2 \%) & 58,8 & 32,4 \\
\hline O-01 (itraukto oro 4,0 \%) & 57,3 & 40,2 \\
\hline O-02 (itraukto oro 5,0 \%) & 52,5 & 36,9 \\
\hline O-03(itraukto oro 10,0 \%) & 38,3 & 28,1 \\
\hline O-06 (itraukto oro 14,0 \%) & 32,9 & 24,2 \\
\hline O-03P (itraukto oro 8,5 \%) & 62,8 & 43,7 \\
\hline O-06P (itraukto oro 12,0 \%) & 55,1 & 31,7 \\
\hline
\end{tabular}

Betono bandiniu su skirtingais oro kiekiais gniuždymo stipris mažèja didèjant oro kiekiui betone, pagal žinomą priklausomybę, kad 1,0\% įtraukto oro sumažina betono gniuždymo stiprị 4-5\%. Padidinus cemento kieki betono mišinyje su oro kiekiu $8,5 \%$ ir $12,0 \%$, gaunamas panašus betono gniuždymo stipris, kaip ir su oro kiekiu 3,2\% ir 4,0\%.

Atlikus vienpusio kaitinimo bandymus gauname, kad didžiausias gniuždymo stiprio sumažèjimas ịvyko su mažiausiu oro kiekiu ir siekia apie $45 \%$. (3.36 pav.) Padidinus oro kiekị betono mišinyje iki 4,0 \%, gaunamas staigus gniuždymo stiprio sumažejimo kritimas iki $30 \%$. Tolesnis oro kiekio didinimas betono mišinyje nežymiai mažina betono stiprio sumažejimą ir nèra efektyvus. Padidinus oro kieki betono mišinyje iki $14 \%$, galima gauti betono gniuždymo stiprio sumažèjimą lygų $26 \%$. Tyrimų rezultatai rodo, kad įtraukto oro kiekio padidinimas betono mišinyje panaudojant orą ịtraukiančią ịmaišą, leidžia efektyviai sumažinti destrukcinius procesus suketejjusiame betone, vykstančius dèl aukštos temperatūros. 


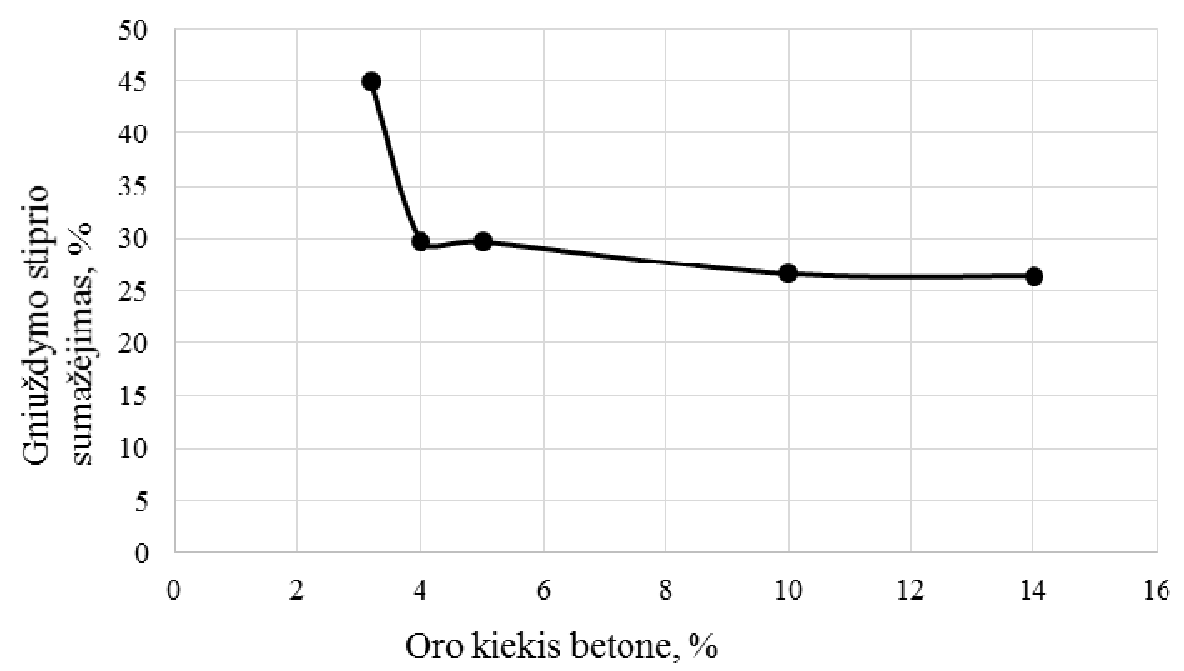

3.36pav. Betono bandinių ( $\mathrm{O}, \mathrm{O}-01, \mathrm{O}-02, \mathrm{O}-03, \mathrm{O}-06)$ gniuždymo stiprio sumažèjimo priklausomybè nuo oro kiekio betone kaitinant vienpusiu būdu

Fig. 3.36. Concrete samples $(\mathrm{O}, \mathrm{O}-01, \mathrm{O}-02, \mathrm{O}-03, \mathrm{O}-06)$ compressive strength decrease dependence from different amount of air of the one side heating

Analogiškas įtraukto oro poveikis pastebimas ir betono irimo procesams dèl užšaldymo ir atšildymo poveikio drègnoje būklèje, kurio metu taip pat susidaro vandens hidrostatinis slègis kapiliarinèse porose cementiniame akmenyje. Efektyvus itraukto oro kiekis betono atsparumo ugniai padidinimui yra 4,0$5,0 \%$.

\subsubsection{Betono su skirtingu oro kiekiu mikrostruktūros pokyčiai veikiant aukštai temperatūrai}

Siekiant ịvertinti ịtraukto oro kiekio ịtaką betono atsparumui ugniai, buvo atlikta betono bandinių su skirtingu oro kiekiu mikrostruktūros analize, naudojant skenuojančią elektroninę mikroskopiją. Paveiksluose 3.36-3.40 pateikiamas betono bandiniu vaizdas su skirtingais oro kiekiais. Betono sudetys pateiktos 2.10 lenteleje. Didinimas siekè nuo 50 iki 15000 kartų.

Iš 3.37 paveikslo matyti, kad bandinių, kuriuose nebuvo dèta orą itraukiančios įmaišos (oro kiekis 3,2 \%) po 3 val. kaitinimo atskiri cementinio akmens fragmentai pradejo atskilinèti nuo bandinio paviršiaus. Bandinių, i kuriuos buvo ịdèta $0,2 \%$ orą ịtraukiančios įmaišos (oro kiekis 5,0 \%) paviršiuje atsirado platūs plyšiai, o bandinių su $14,0 \%$ oro kiekiu paviršius liko mažiausiai pakitęs, su nedideliais pažeidimais, smulkiais plyšiais. 


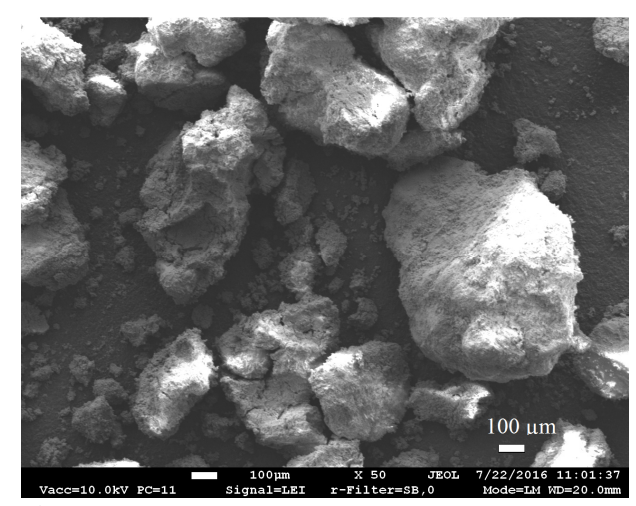

a)

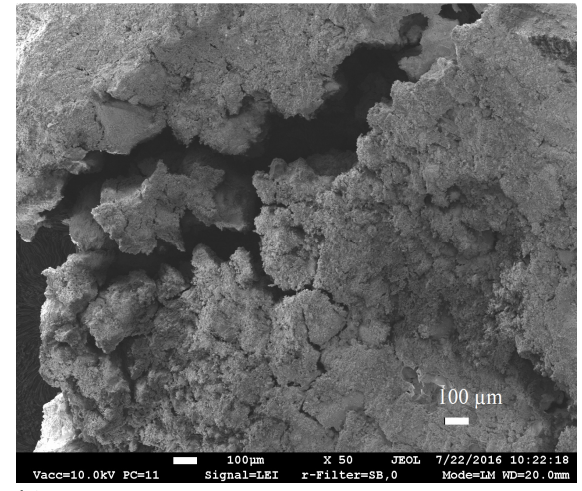

b)

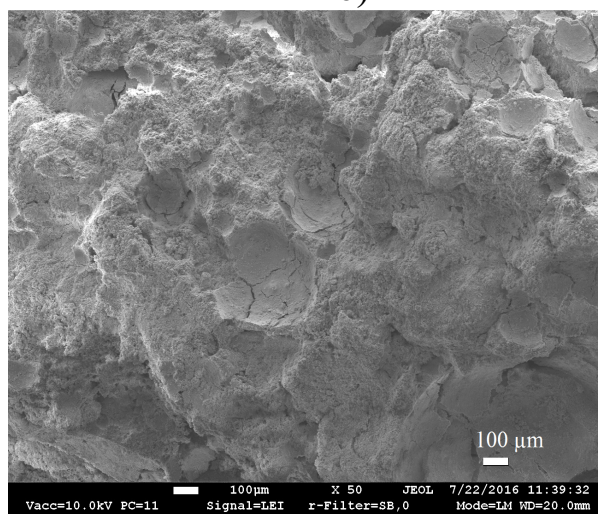

c)

3.37 pav. Betono bandinių su skirtingu itrauktu oro kiekiu kaitinto paviršiaus mikrostruktūra (50 kartų didinimas): a) O (itraukto oro $3,2 \%$ ); b) $\mathrm{O}-02$ (itraukto oro $5,0 \%$ ); c) O-06 (itraukto oro $14,0 \%$ )

Fig. 3.37. Concrete specimens with entrained air of one side heating a refraction microstructure: a) O (3.2\% entrained air); b) O-02 (5.0\% entrained air);

c) $\mathrm{O}-06(14.0 \%$ entrained air $)$

Tokị efektą galima būtų paaiškinti tuo, kad vandens garai plito ị oro poras, susidarè mažesnis slègis ir mažesni vidiniai įtempimai. Cementinèje matricoje su mažesniu kiekiu oro porų vandens garai besiverždami iš vidinių sluoksnių ardè medžiagą ir sukèlè gilius įtrūkius arba cementinio akmens fragmentų atskilinèjimą nuo paviršiaus. Buvo atlikta vidinių betono sluoksnių $(5 \mathrm{~cm}$ atstumu nuo kaitinamo paviršiaus) mikrostruktūros analizè, kuri pateikta 3.38 paveiksle. 


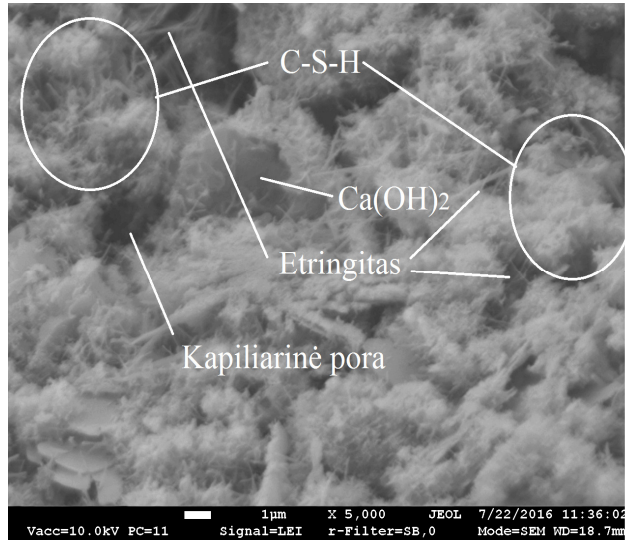

a)

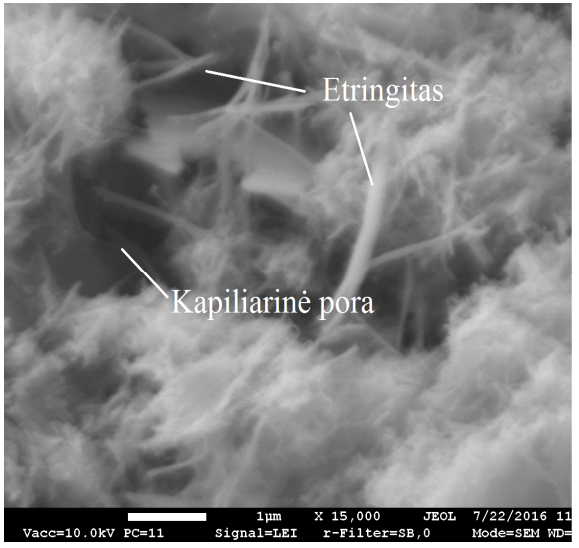

b)

3.38 pav. Betono bandinių O (ịtraukto oro 3,2 \%) nekaitinto paviršiaus lūžio mikrostruktūra: (a) 5000 kartų didinimas (b) 15000 kartų didinimas

Fig. 3.38. Concrete samples $\mathrm{O}$ with (entrained air $3.2 \%$ ) refraction microstructure from not heated surface: a) 5000 magnification times (b) 15000 magnification times

Betone be orą įtraukiančios įmaišos (3,2 \% oro kiekis), mažai paveiktame aukštos temperatūros iki $200{ }^{\circ} \mathrm{C}$ nekaitintoje bandinio pusèje cementinio akmens mikrostruktūroje galima išskirti eilinius cemento hidratacijos produktus: kalcio hidrosilikatų smulkių plaušelių sankaupas, stambias kalcio hidroksido heksagonalines plokšteles, lazdelių formos etringito kristalus bei hidratacijos produktais neužpildytas kapiliarines poras (3.38 pav. a ir b). Šie hidratacijos produktai turi klasikinę morfologiją tai rodo, kad jų nepakeitè minètas temperatūrinis poveikis.

Betono su padidintu oro kiekiu iki 5,0\% temperatūros nepaveiktos pusès ir aukštos temperatūros paveiktos centrinès dalies mikrostruktūros nuotraukos pateikiamos 3.39 pav.

Palyginus betono su $5 \%$ oro kiekiu mikrostruktūrą atskirų zonų paveiktos nedidele iki $200{ }^{\circ} \mathrm{C}$ temperatūra ir aukštos temperatūros iki $500-600{ }^{\circ} \mathrm{C}$, matome, kad tiek vienoje tiek kitoje zonoje pranyksta etringito kristalai, tačiau išlieka nepakitusios kalcio silikatų smulkių plaušelių sankaupos. Žemos temperatūros paveiktoje zonoje, matomos heksagonalinès kalcio hidroksido plokštelès, kurių nèra aukštos temperatūros zonoje. Aukštos temperatūros zonoje atsiranda neapibrèžtos formos kristalai, kuriuos galima priskirti kalcio oksidui $(\mathrm{CaO})$. 


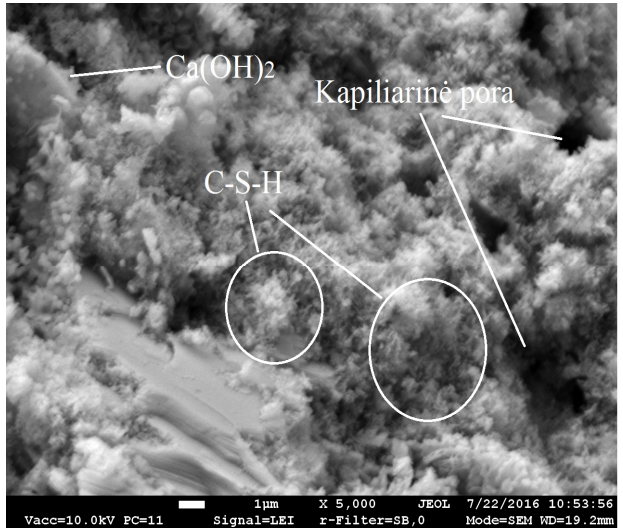

a)

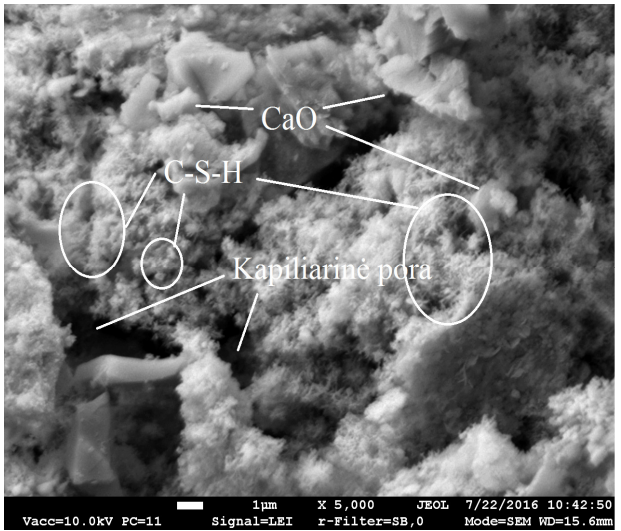

b)

3.39 pav. Betono bandinių O-02 (ịtraukto oro 5,0 \%) lūžio mikrostruktūra (5000 kartų didinimas): a) nekaitinto paviršiaus; b) bandinio centro

Fig. 3.39. Concrete samples O-02 (entrained air 5.0\%) refraction microstructure (5000 magnification times): a) from not heated surface; b) sample center

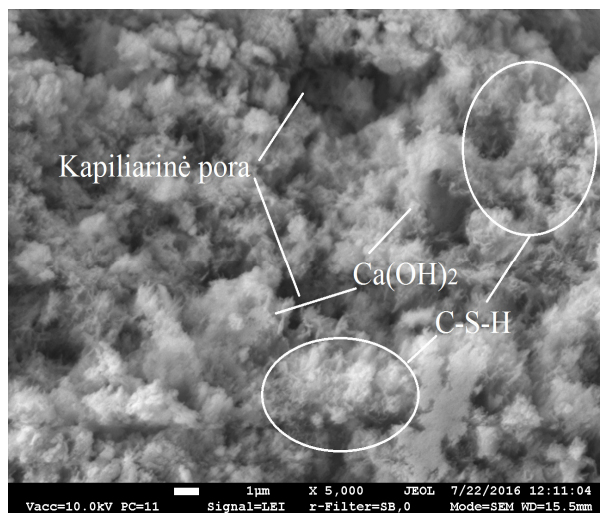

a)

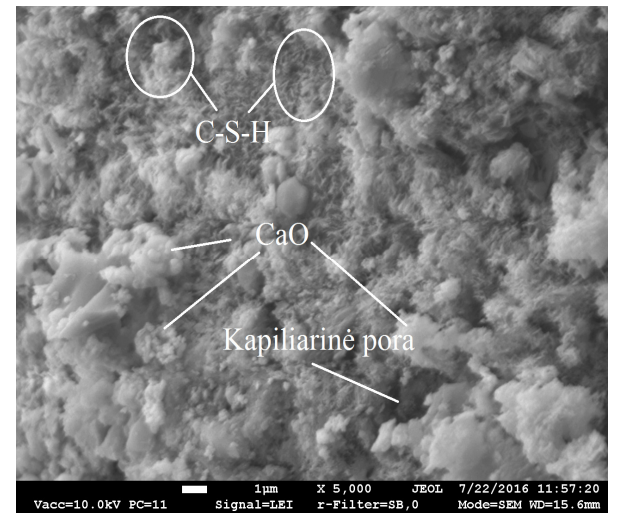

b)

3.40 pav. Betono bandinių O-06 (įtraukto oro 14,0 \%) lūžio mikrostruktūra (5000 katų didinimas: a) nekaitinto paviršiaus; b) bandinio centro

Fig. 3.40. Concrete samples O-06 (entrained air 14.0\%) refraction microstructure, 5000 magnification times: a) from not heated surface b) samples center

Palyginus betono su $14 \%$ oro kiekiu mikrostruktūros vaizdą aukštos temperatūros zonoje $\left(500-600^{\circ} \mathrm{C}\right)$ ir žemesnès temperatūros zonoje $\left(200{ }^{\circ} \mathrm{C}\right)$ išnyksta entringito kristalai. Kalcio hidroksido heksagonalinès plokštèlès matomos žemos temperatūros paveiktoje zonoje, tačiau jų nėra aukštos temperatūros 
zonoje. Vietoje kalcio hidroksido plokštelių auštos temperatūros zonoje matomi neaiškios formos kristalai kuriuos galime priskirti kalcio oksidui.

Po aukštos temperatūros poveikio, betono bandinių centre $\left(500-600{ }^{\circ} \mathrm{C}\right)$ susidaro didelis kiekis mikro plyšių (3.4 pav), kietoje fazèje, kurie žymiai sumažina cementinio akmens stiprumą.

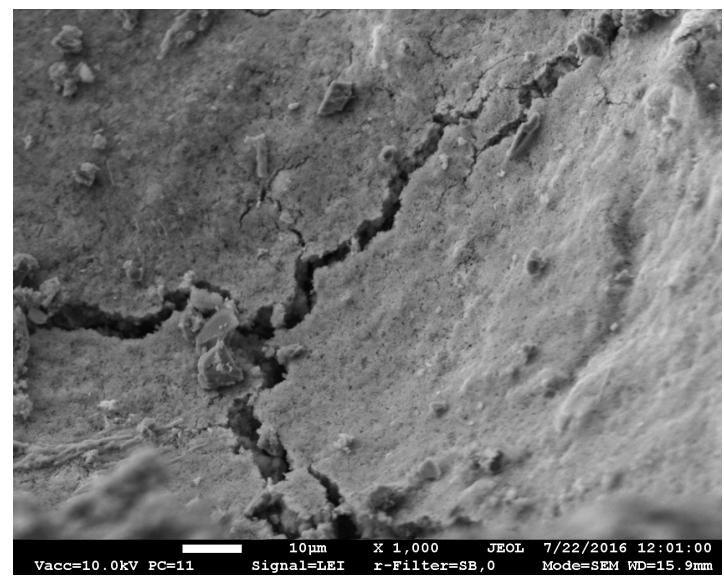

3.41 pav. Betono bandinių mikro plyšių vaizdas bandinio centre (1000 kartų didinimas)

Fig. 3.41. Concrete samples micro-cracks image in the center of the sample (1000 magnification times)

\subsubsection{Temperatūrinio režimo betone gaisro metu prognozavimas}

Iš eksperimentų metu gautų temperatūrinių kreivių galima tiksliai prognozuoti susidarančias temperatūras skirtinguose betono su klinties portlandcemenčiu ir dolomito užpildu sluoksniuose nuo kaitinamo paviršiaus po skirtingos laiko trukmès. Prognozavimas atliktas veikiant betono paviršių temperatūra, kuri kinta pagal standartinę gaisro kreivę, kaitinant vienpusiai. Taip yra modeliuojamas temperatūros poveikis (analogiškas gaisrui) atitvarinèms konstrukcijoms, kai liepsna ir karštis veikia iš vienos pusès. Naudojant programinę įrangą statistiniams skaičiavimams nustatyta, kad minètas kreives galima gana tiksliai (koreliacijos koeficientas 0,97 ) aprašyti polinominèmis funkcijomis, kurios pateiktos 3.9 lentelèje. Atlikus regresinę analizę buvo sudarytos empirinès lygtys (3.8 lentelè), pagal kurias galima prognozuoti betono temperatūrą $\left(\mathrm{T},{ }^{\circ} \mathrm{C}\right)$ po pasirinkto kaitinimo laiko $(\tau, \mathrm{min})$ ir pasirinktu atstumu nuo kaitinimo paviršiaus (a, cm). Lygčių koreliacijos ir determinacijos koeficientai pateikiami 3.9 lentelèje. 
3.9 lentelè. Temperatūros betone gaisro metu, kaitinant vienpusiai prognozavimo empirinès lygtys

Table 3.9. Empirical formula to temperature prediction in fire of concrete from the one side heating

\begin{tabular}{|c|c|c|c|}
\hline Sudėties žymuo & Empirinè lygtis & $\begin{array}{l}\text { Koreliacijos } \\
\text { koeficientas }\end{array}$ & $\begin{array}{c}\text { Determinacijos } \\
\text { koeficientas }\end{array}$ \\
\hline $\begin{array}{c}\mathrm{O} \\
\text { (itraukto oro 3,2\%) }\end{array}$ & $\begin{array}{c}\mathrm{T}=439,1+8,323 \tau-0,025 \tau^{2}- \\
226,03 \mathrm{a}+24,72 \mathrm{a}^{2}-0,142 \tau \mathrm{a}\end{array}$ & 0,976 & 0,952 \\
\hline $\begin{array}{c}\text { O-01 } \\
\text { (itraukto oro } 4,0 \% \text { ) }\end{array}$ & $\begin{array}{c}\mathrm{T}=448.5+8,365 \tau-0,025 \tau^{2}- \\
245.1 \mathrm{a}+27.77 \mathrm{a}^{2}-0,190 \tau \mathrm{a}\end{array}$ & 0,974 & 0,948 \\
\hline $\begin{array}{c}\text { O-02 } \\
\text { (itraukto oro } 5,0 \%)\end{array}$ & $\begin{array}{c}\mathrm{T}=425,3+8,015 \tau-0,023 \tau^{2}- \\
229,1 \mathrm{a}+25,89 \mathrm{a}^{2}-0,183 \tau \mathrm{a}\end{array}$ & 0,974 & 0,948 \\
\hline $\begin{array}{c}\text { O-03 } \\
\text { (itraukto oro } 10,0 \% \text { ) }\end{array}$ & $\begin{array}{c}\mathrm{T}=441,2+8,533 \tau-0,026 \tau^{2}- \\
223,6 \mathrm{a}+23,66 \mathrm{a}^{2}-0,201 \tau \mathrm{a}\end{array}$ & 0,977 & 0,955 \\
\hline $\begin{array}{c}\text { O-06 } \\
\text { (itraukto oro } 14,0 \%)\end{array}$ & $\begin{array}{c}\mathrm{T}=436,63+8,554 \tau-0,027 \tau^{2}- \\
214,6 \mathrm{a}+22,34 \mathrm{a}^{2}-0,181 \tau \mathrm{a}\end{array}$ & 0,976 & 0,953 \\
\hline $\begin{array}{c}\mathrm{O}-03 \mathrm{P} \\
\text { (itraukto oro } 8,5 \% \text { ) }\end{array}$ & $\begin{array}{c}\mathrm{T}=424,4+8,196 \tau-0,024 \tau^{2}- \\
223,3 \mathrm{a}+24,78 \mathrm{a}^{2}-0,203 \mathrm{ta}\end{array}$ & 0,976 & 0,952 \\
\hline $\begin{array}{c}\mathrm{O}-06 \mathrm{P} \\
\text { (itraukto oro } 12,0 \%)\end{array}$ & $\begin{array}{c}\mathrm{T}=434,5+8,228 \tau-0,024 \tau^{2}- \\
230,2 \mathrm{a}+25,62 \mathrm{a}^{2}-0,204 \tau \mathrm{a}\end{array}$ & 0,976 & 0,952 \\
\hline
\end{tabular}

Kadangi lygčių koeficientai mažai skiriasi buvo sudarytos apibendrintos lygtys betonui be orą įtraukiančios įmaišos (3.1) ir su orą įtraukiančia ịmaiša (3.2):

$$
\begin{gathered}
\mathrm{T}=439+8,3 \tau-0,025 \tau^{2}-226 \mathrm{a}+25 \mathrm{a}^{2}-0,14 \tau \mathrm{a} ; \\
\mathrm{T}=435+8,3 \tau-0,025 \tau^{2}-227 \mathrm{a}+25 \mathrm{a}^{2}-0,19 \tau \mathrm{a} .
\end{gathered}
$$

3.1 lygtis naudojama, kai betone nebuvo dèta orą ịtraukiančios įmaišos, 3.2 lygtis naudojama, kai ị mišini dedama orą ịtraukianti ịmaiša.

Polinominè priklausomybe pagal 3.1-3.2 empirines lygtis pateikta 3.423.43 paveiksle. Kadangi plieno kritinè temperatūra gaisro metu yra $500{ }^{\circ} \mathrm{C}$, svarbu, kad gaisro metu betono sluoksnis, kuriame yra armatūra, nepasiektų kuo ilgiau šios kritinès temperatūros.

3.42 paveiksle pateiktą priklausomybę galima naudoti betonui be oro itraukiančios įmaišos. 3.43 paveiksle pateiktą priklausomybę galima panaudoti betonui su orą įtraukiančia įmaiša, kai betone yra oro kiekis didesnis už 4,0 \%. 


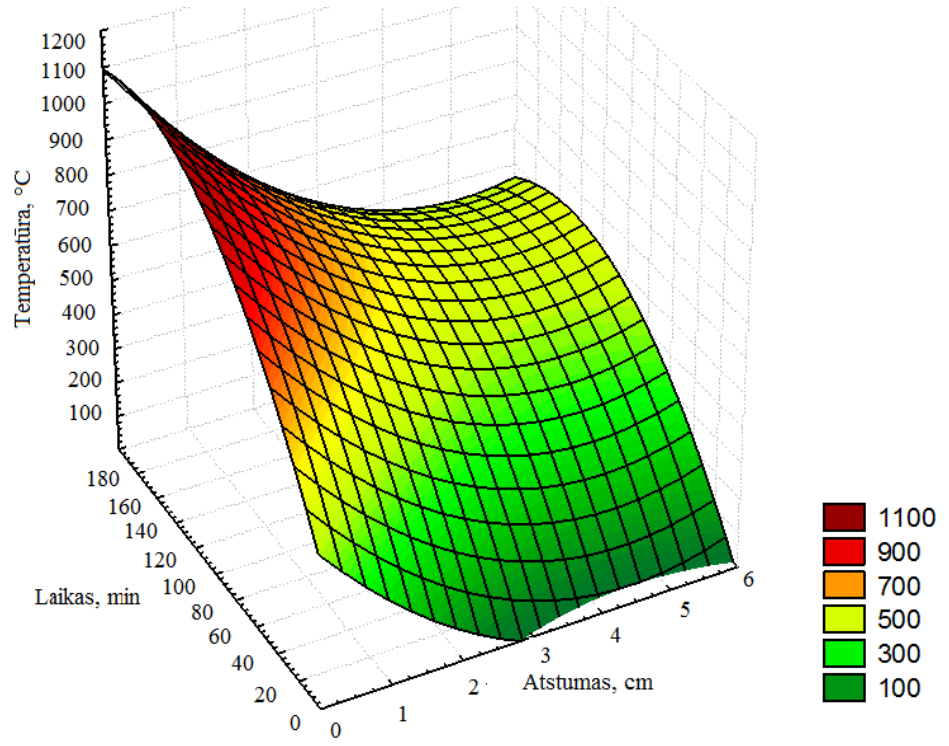

3.42 pav. Temperatūros priklausomybè nuo laiko ir atstumo nuo bandinio paviršiaus, kaitinant vienpusiai, pagal 3.1 empirinę lygti

Fig. 3.42. The temperature dependence on time and distance from the surface in accordance with 3.1 empirical formula from the one side heating

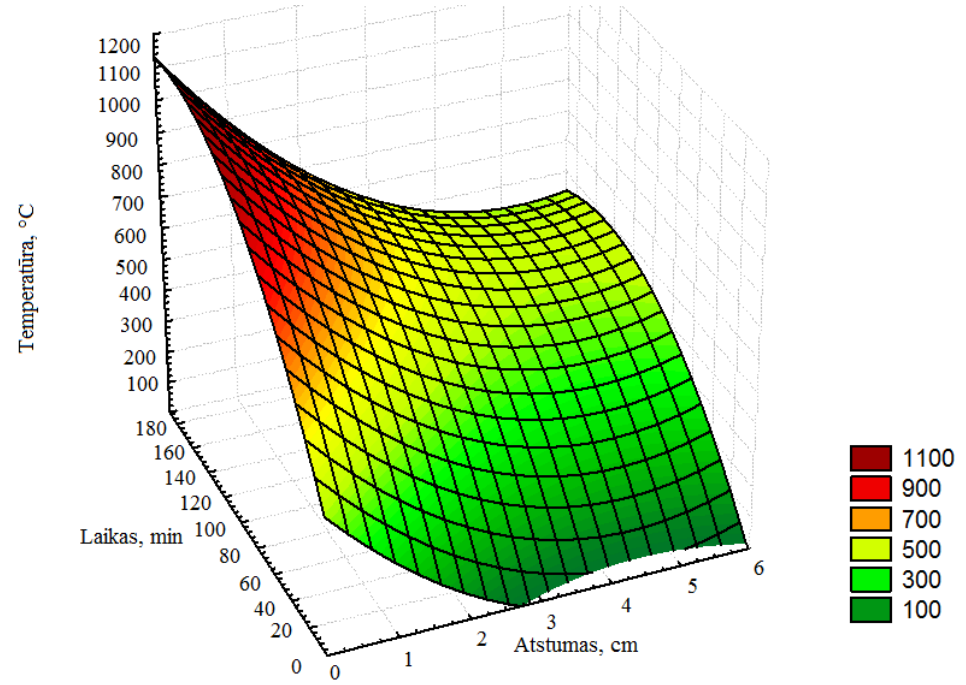

3.43 pav. Temperatūros priklausomybė nuo laiko ir atstumo nuo bandinio paviršiaus, kaitinant vienpusiai, pagal 3.2 empirinę lygtị

Fig. 3.43. The temperature dependence on time and distance from the surface of the test in accordance with 3.2 empirical formula from the one side heating 
Iš tyrimų rezultatų matyti, kad gautas betonas $5 \mathrm{~cm}$ atstume nuo kaitinamo paviršiaus po 180 min nepasiekè kritinès $500{ }^{\circ} \mathrm{C}$ temperatūros, kai įtraukto oro kiekis betone buvo didesnis už 4,0\%,3 cm atstume nuo kaitinamo paviršiaus minèta temperatūra nepasiekiama po $100 \mathrm{~min}$, o $2 \mathrm{~cm}$ atstume - po $60 \mathrm{~min}$.

\subsection{Trečiojo skyriaus išvados}

1. Vienpusiu kaitinimo metodu tiriant temperatūrų pasiskirstymą betono bandiniuose su skirtingais cementais $5 \mathrm{~cm}$ atstumu nuo kaitinamo paviršiaus, nustatyta aukščiausia temperatūra su smulkiai maltu cementu (CEM I 42,5R) - ji siekia $613{ }^{\circ} \mathrm{C}$, o mažiausia $589{ }^{\circ} \mathrm{C}$ temperatūra užfiksuota su cementu neturinčiu mineralinių priedų (CEM I 42,5N) ir $17 \%$ klinties turinčiu cementu (CEM II A-LL 42,5 N).

2. Betone su šlakiniu cementu, kuriame yra $70 \%$ aukštakrosnių šlako, kaitinimo metu dèl intensyviu adsorbuoto vandens garavimo pasireiškia sprogstamoji irtis, todèl šis cementas nerekomenduojamas betonui, kuriam keliami padidinti atsparumo ugniai reikalavimai.

3. Vertinant betonų su skirtingais cementais masès nuostolius ir ultragarso sklidimo greičio pokyčius po vienpusio terminio poveikio žymių skirtumų nenustatyta, tačiau betono gniuždymo stiprio sumažèjimas po vienpusio terminio poveikio su $17 \%$ klinties priedo turinčiu cementu yra žymiai mažesnis ir sudaro $12,5 \%$, tuo tarpu su kitais cementais jis siekia 27,0 $30,5 \%$.

4. İvertinus termogravimetrinių tyrimų rezultatus, galima išskirti penkis cementinio akmens kitimo etapus, kurie gali sukelti destrukcinius procesus veikiant aukštai temperatūrai: $100-130{ }^{\circ} \mathrm{C}$ temperatūroje laisvo ir adsorbuoto vandens pasišalinimas, $140-170{ }^{\circ} \mathrm{C}$ temperatūroje hidroaliuminatų irimas, $430-470{ }^{\circ} \mathrm{C}$ temperatūroje kalcio hidrosilikatų dehidratacija, 600$670{ }^{\circ} \mathrm{C}$ kalcio hidroksido dehidratacija, $670-730{ }^{\circ} \mathrm{C}$ temperatūroje kalcio karbonatų disociacija. Šiems procesams turi įtakos cemento mineralinė sudètis ir cemente esantys mineraliniai priedai.

5. Dilatometriniai betono tyrimai rodo, kad didinant temperatūrą iki $1000{ }^{\circ} \mathrm{C}$ cementinis akmuo su skirtingais mineraliniais priedais plečiasi iki $0,2-$ $0,4 \%$, aušinant cementinis akmuo traukiasi nuo $-0,4 \mathrm{iki}-0,9 \%$. Bendra cementinio akmens deformacija su šlakiniu cementu siekia apie $1 \%$, o su cementu be priedų ir cementu su klinčių priedu yra apie du kartus mažesnè, dèl susidarančio mažesnio skystosios fazès kiekio aukštoje temperatūroje.

6. Temperatūros betone su skirtingais užpildais kaitinant vienpusiu metodu $5 \mathrm{~cm}$ atstumu nuo kaitinamo paviršiaus po 3 valandų kaitinimo pagal standartinę gaisro kreivę pasiekia tokias ribas: su cementu neturinčiu priedų bei 
žvirgždo užpildu $551{ }^{\circ} \mathrm{C}$, su granito užpildu $560{ }^{\circ} \mathrm{C}$, su keramzito užpildu $540{ }^{\circ} \mathrm{C}$, su dolomito užpildu $531{ }^{\circ} \mathrm{C}$, su cementu turinčiu $17 \%$ klinties priedo bei žvirgždo užpildu $530{ }^{\circ} \mathrm{C}$, su granito užpildu $567{ }^{\circ} \mathrm{C}$, su keramzito užpildu $565^{\circ} \mathrm{C}$, su dolomito užpildu $509^{\circ} \mathrm{C}$. Betonuose su dolomito užpildu ir su cementu be priedų bei cementu su $17 \%$ klinties priedu gaunama mažiausia temperatūra $5 \mathrm{~cm}$ atstumu nuo kaitinamo paviršiaus.

7. İvertinus vienpusị ir tūrinio bandymų metodus, kaitinant betono bandinius pagal standartinę gaisro kreivę, nustatyta, kad statinio konstrukcijos gaisro metu gali būti veikiamos vienpusiu ir tūriniu būdu, priklausomai nuo konstrukcijos paskirties ir padèties gaisro metu, todèl šie skirtingi betono atsparumo ugniai bandymo metodai gali būti taikomi ịvairioms statinio konstrukcijoms, atsižvelgiant $i$ jų panaudojimą.

8. Termogravimetrijos tyrimai iki $1000{ }^{\circ} \mathrm{C}$ temperatūros rodo, kad dažniausiai naudojamuose užpilduose (smèlis, žvirgždas, dolomitas) skyla kalcio ir magnio karbonatai, užfiksuotos skilimo temperatūros ribos yra nuo $650{ }^{\circ} \mathrm{C}$ iki $800{ }^{\circ} \mathrm{C}$. Užpilduose neturinčiuose karbonatinių uolienų (granitas, keramzitas) jokie pokyčiai termogramose neužfiksuoti.

9. Dilatometriniai betono su skirtingais užpildais tyrimai rodo plètimosi bei susitraukimo deformacijas prie $573{ }^{\circ} \mathrm{C}$, kuri charakterizuoja kvarco kristalinès gardelès pokyčius. Liekamoji betono su skirtingais užpildais deformacijos kaitinant iki $1000^{\circ} \mathrm{C}$ temperatūros mažiausios su keramzito užpildu $(0,2 \%)$ ir su dolomito užpildu $(0,4 \%)$, didžiausios deformacijos su žvirgždo užpildu $(1,0 \%)$ ir su granito užpildu $(0,8 \%)$. Didžiąją tūrio dalị betone sudaro užpildas, todèl užpildo deformacijos veikiant aukštai temperatūrai turi didelę itaką betono atsparumui ugniai.

10. Betono su skirtingais užpildais gniuždymo stiprio sumažejimas po aukštos temperatūros poveikio kaitinant vienpusiu būdu priklauso nuo užpildo ir svyruoja 43-49 \% ribose, išskyrus keramzito užpildą (lengvajam betonui), kai betono gniuždymo stiprio pokytis po kaitinimo yra žymiai mažesnis ir siekia $25-26 \%$.

11. Didejjant įtraukto oro kiekiui betone, mažèja masès nuostoliai, ultragarso greičio pokytis, gaunamos žemesnès perkaitimo temperatūrų vertès ir mažesni betono stiprio sumažèjimai po temperatūrinio poveikio pagal standartinę gaisro kreivę atliekant bandymus vienpusiu kaitinimo metodu. Esant $5 \%$ ịtaukto oro kiekiui betone (su $0,2 \%$ orą įtraukiančios įmaišos) jo gniuždymo stipris po 3 valandų kaitinimo sumažeja 29,7 \%, kai tuo tarpu esant oro kiekiui 3,2\% (be orą ịtraukiančios įmaišos) gniuždymo stipris sumažèja 44,9 \%. Šie gauti skirtumai gali būti aiškinami betono poringumo pokyčiais. Betone esančios uždaros oro poros leidžia plèstis kaitinimo metu susidariusiems vandens garams ir taip sumažina vidinius ịtempius cementi- 
niame akmenyje. Tačiau ịtraukto oro kiekis virš $5 \%$ neturi didelès įtakos betono stiprumo sumažèjimui po vienpusio terminio poveikio.

12. Naudojant orą ịtraukiančias įmaišas galima gaminti padidinto atsparumo ugniai cementinius betonus, kurių apsauginio sluoksnio storis priklauso nuo norimos gauti atsparumo ugniai klasès ir gali būti parinktas pagal autoriaus nustatytas grafines priklausomybes. 


\section{Bendrosios išvados}

1. Temperatūriniam poveikiui atspariam betonui gaminti labiausiai tinka cementas su klinties priedu (CEM II A-LL tipo). Betonu su skirtingais cementais temperatūrinių laukų matavimai $5 \mathrm{~cm}$ atstumu nuo kaitinamo paviršiaus po 3 valandu poveikio pagal standartinę gaisro kreivę kaitinant vienpusiu būdu rodo, kad su cementu su klinties priedu pasiekiama žemiausia temperatūra (apie $24{ }^{\circ} \mathrm{C}$ ) ir mažiausias gniuždymo stiprio praradimas, kuris siekia $12,5 \%$ lyginant su kitais tirtais cementais, kurie praranda 27,0-30,5\% gniuždymo stiprio. Tai galima paaiškinti mažesniu adsorbuotu vandens kiekiu tokiame cementiniame akmenyje bei karbonatinio priedo irimu aukštesnèse temperatūrose.

2. Keramzito užpildas turi pranašumą atsparumo ugniai požiūriu lyginant su kitais užpildais. Betono su šiuo užpildu gniuždymo stipris sumažèja apie 25$26 \%$, tuo tarpu betono su kitais užpildais - 43-49 \%. Tai aiškinama mažesnėmis betono su tokiu užpildu terminèmis deformacijomis. Atlikus temperatūrų pasiskirstymo tyrimus su skirtingais betono užpildais pagal standartinę gaisro kreivę kaitinant vienpusiai gauta, kad $5 \mathrm{~cm}$ atstumu pasiekiama mažiausia temperatūra su dolomito užpildu $531^{\circ} \mathrm{C}$ (su cementu, neturinčiu mineralinio priedo), $509^{\circ} \mathrm{C}$ (su cementu, turinčiu klinties priedą).

3. Padidinus oro kieki betono mišinyje iki 4-5 \% žymiai sumažèja betono gniuždymo stiprio nuostoliai po terminio poveikio - nuo $44,9 \%$, kai oro 
kiekis lygus 3,2 \% (betonas be orą ịtraukiančios įmaišos) iki 29,8 \%, kai oro kiekis 4,0\%; 29,7\%, kai oro kiekis $5 \%$; 26,6\%, kai oro kiekis $10 \%$; $26,4 \%$, kai oro kiekis $14 \%$. Temperatūrinių laukų tyrimai rodo, kad $5 \mathrm{~cm}$ atstume nuo kaitinamo paviršiaus betone su $5 \%$ įtraukto oro kiekiu temperatūra yra apie $31{ }^{\circ} \mathrm{C}$ žemesnè negu temperatūra betone be orą įtraukiančios imaišos. Gauti rezultatai aiškinami dideliu betono uždaru poringumu, kuris kompensuoja susidarančius vidinius įtempius bei vandens garų slègi terminio poveikio metu.

4. Geriausi rezultatai betono atsparumo ugniai požiūriu pasiekti su cementu, turinčiu klinties priedo, dolomito stambiuoju užpildu ir $5 \%$ įtraukto oro kiekiu. Po temperatūrinio poveikio pagal standartinę gaisro kreivę veikiant vienpusiai, toks betonas po 3 valandų kaitinimo praranda 29,7 \% gniuždymo stiprio. Betono temperatūros verte $5 \mathrm{~cm}$ atstume nuo kaitinamo paviršiaus nesiekia $480{ }^{\circ} \mathrm{C}$ temperatūros. Padidinus įtraukto oro kiekị iki $5 \%$ galima gaminti gelžbetonines konstrukcijas su $5 \mathrm{~cm}$ apsauginiu betono sluoksniu, kurių atsparumas ugniai siektų REI 180.

5. Išvestos empirinès temperatūros pasiskirstymo betone lygtys kaitinant vienpusiai leidžia prognozuoti temperatūrinị režimą betono apsauginiame sluoksnyje gaisro metu ir gali būti naudojamos tiksliau ịvertinti reikiamam jo storiui iki armatūros gelžbetoninėse konstrukcijose. 


\section{Literatūra ir šaltiniai}

Anderberg, Y. Spalling phenomena of HPC and OC, Proceedings of the International workshop on fire performance of high-strength concrete, NIST, Gaithesburg, USA, 1997. $180 \mathrm{p}$

Antonovič, V. 1999. Natrio silikato ir jo tirpalo ịtaka kaitrai atsparaus betono savybèms. Daktaro disertacija. Vilniaus Gedimino technikos universitetas. Vilnius.

Arioz, O. 2007. Effects of elevated temperatures on properties of concrete. Fire Safety Journal 42: 516-522.

Balandis A.; Kaminskas R.; Vaickelionis G. 2004 Statybinių medžiagų chemija II dalis Neorganinių rišamujų medžiagų chemija Kaunas: Technologija. 86 p.

Bamonte, P.; Lo Monte, F. 2015 Reinforced concrete columns exposed to standard fire: Comparison among different constitutive models for concrete at high temperature. Fire Safety Journal 71: 310-323.

Bilodeau, A.; Malhotra, V. M. 2000. High-volume fly ash system: concrete solution for sustainable development. ACI Material Jounal. 97 (1), 41-48.

Bilodeau, A.; Kodur, V.K.R.; Hoff, G.C. 2004 Optimization of the type and amount of polypropylene fibres for preventing the spalling of lightweight concrete subjected to hydrocarbon fire, Cement Concrete Composision 26 (2): 163-174. 
Bo Wu; Wei Xiong; Bo Wen. 2014 Thermal fields ofcrackedconcretemembersin fire. Fire Safety Journal 66: 15-24.

Bosiljkov, V.B. 2003. SCC mixes with poorly graded aggregate and high volume of limestone filler. Cement Concrete Reserch 33: 1279-1286.

Boulder Canyon Project Report 1995. Thermal properties of concrete. Final Report by USBR, Bulletin No. 1, Part VII, 1940. India: 162-6.

Carmen I,; Jose V.; Aguado S,; Manuel L.; Romero, Espinos A,; Hospitaler A,; 2015. Fire design method for concrete filled tubular columns based on equivalent concrete core cross-section. Fire Safety Journal 78: 10-23.

Castellote, M.; Alonso, C.; Andrade, C.; Turrillas, X.; Campo, J. 2004. Composition and microstructural changes of cement pastes upon heating, as studied by neutron diffraction. Cement and Concreate Research 34:1633-1644.

Chan, S.Y.N.; Peng, G. F.; Anson, M 1996. Comparison between high-strength concrete and normal-strength concrete subjected to high temperature, Material Structure. 29 (1): 616-619.

Chotard, T.; Gimet-Breart, N.; Smith, A. 2001. Application of ultrasonic testing to describe the hydration of calcium aliuminate cement at the early age. Cement and Concreate Research Journal 30: 405-412.

Čekanavičius, V.; Murauskas, G. Statistika ir jos taikymai. 2 d. Vilnius: TEV, 2004, $272 \mathrm{p}$.

Debicki, G.; Haniche, R.; Delhomme, F. (2012). An experimental method for assessing the spalling sensitivity of concrete mixture submitted to high temperature. Cement and Concreate Composites 30: 112-121

Deltuva, J.; Gailius, A.; Gumuliauskas, A.; Kulikauskas, L.; Malakuskas, M.; Martynaitis, M. 1982 Statybinès medžiagos. Vadovèlis. Vilnius: Mokslas. 348 p.

Demirel, B.; Kelestemur, O. 2010. Effect of elevated temperature on the mechanical properties of concrete produced with finely ground pumice and silica fume. Fire Safety Journal 45: 385-391.

Drysdale, D. 1998. An introduction to fire dynamics. Second Editon. John and sons, $447 \mathrm{p}$.

Eisinas, A.; Baltakys, K. 2009. Portlandito kiekio hidratuotame portlancementyje nustatymas vienalaikès terminès analizès metodu, Cheminè technologija 1: 1392-1231.

El-Dieb, A. S. 2009. Mechanical, durability and microstructural characteristics of ultrahigh- strength self-compacting concrete incorporating steel fibers. Material Designe 30 (10): 4286-4292.

Elzbutas H. Statybinių medžiagų savybių ir struktūros ypatybių tyrimo metodai. Kaunas: Vitae Litera. 2007. 147 p. 
Erline, B.; Hime, W. G.; Kueneeing, W.H. 1972 Evaluating fire damage to concrete structures, Concreat Construction. 154-159.

Garboczi, E. J.; Bentz, D. P. 1996. Modelling of the microstructure and transport properties of concrete. Construction Building Material. 10: 293-300.

Gawin, D.; Pesavento, F.; Schrefler, B.A. 2003 Modelling of hygro-thermal behaviour of concrete at high temperature with thermo-chemical and mechanical material degradation, Computer Methods in Applied Mechanics and Engineering 192: 1731-1771.

Gawin, D.; Pesavento, F.; Schrefler, B.A. 2004 Modelling of deformations of highstrength concrete at elevated temperatures, Concreat 37 (268): 218-236.

Gawin, D.; Pesavento, F.; Schrefler, B.A. 2006 Towards prediction of the thermal spalling risk through a multi-phase porous media model of concrete, Compuer Methods in Applied Mechanics and Enginearing, Vol. 195: 5707-5729.

Goberis, S.; Antonovič, V. 2007. Kaitrai atsparūs šamotbetoniai Vilnius, Technika. 360 p. ISBN 978-9955-28-210-5.

Gribniak, V.; Bačinskas, D.; Kaklauskas, G. 2006. Gaisro temperatūra veikiamų laikančiųjų gelžbetoninių tunelio elementų elgsenos skaitinio modeliavimo strategija, The Baltic Journal of Road and Bridge Engineering 1(1): 5-9.

Handoo, S. K.; Agarwal, S.; Agarwal, S.K. 2002 Physicochemical, mineralogical, and morphological characteristics of concrete exposed to elevated temperatures. Cement and Concrete Research 32: 1009-1018.

Heinz, D.; Gobel, M.; Hilbig, H. et al., 2010 Effect of TEA on fly ash solubility and early age strength of motor, Cement Concrete. Research 40: 392-397.

Hertz, K. D. 2003 Limits of spalling of fireexposed concrete, Fire Safety Journal, 38: 103-116.

Hertz, K. D.; Sorensen, L.S. 2005 Test method for spalling of fire exposed concrete, Fire Safety Journal, 40: 466-476.

Heskestad, G.; Delichatsios, M.A. 1989. Short Communication. Update: The Initial Convective Flow in Fire, Fire Safety Journal 15:471-475.

Hojae Lee; Cho Jae-Leon; Yoon, Eui-Sik; Cho Myungsug; Kim Do-Gyeum 2016. Assessment of mass fraction and melting temperature for the application of limestone concrete and siliceous concrete to nuclear reactor basemat considering molten core concrete interaction. Nuclear Engineering and Technology 48:448-456.

Hung, Y.; Wong, Y.; Poon, C.; Anson, M. 2001. Impact of high temperature on PFA concrete. Cement and Concreate Research 31: 1065-1073.

Jalal Mostafa; Fathib Mojtaba; Farzad Mohammad. 2013. Effects of fly ash and TiO 2 nanoparticles on rheological, mechanical, microstructural and thermal properties of high strength self compacting concrete. Mechanics of Materials. 61:11-27. 
Jansen, D.; Goetz-Neunhoeffer, F.; Stabler, C.; Neuauer, J. A. 2011 Remastered external standard method applied to the quan tification of early OPC hydration, Cement and Concrete. Research. 41: 602-608.

Jonaitis, B.; Papinigis, V. 2005. Ilgalaikès apkrovos ir gaisro temperatūru ịtaka betono mechaninėms savybėms, Journal of Civil Engineering and Management 11(4): 283-288.

Jonaitis, B.; Papinigis, V. 2006 Naujas Europos sajungos gaisro veikiamų gelžbetoninių konstrukciju projektavimo metodika, Technological and Economic Development of Economy 12(2): 108-117.

Kalliopi, K. A. Pore structure of cement-based materials. Testing, interpretation and requirements. Modern concrete technology series. vol.12. 2006. p 1-33.

Khan, M.; Bhattacharjee, B. Relationship 1995between thermal conductivities of aggregate and concrete. In: Reddy RR, editor. Civil engineering materials and structures. Osmania University Hyderabad, India:162-169.

Khan, M. I. 2002. Factors acting the thermal properties of concrete and applicability of its prediction models School of Civil Engineering, University of Nottingham, Nottingham NG7 2RD, UK Building and Environment 37: 607-614.

Khoshnazar, R.; Beaudoin, J. J, Alizadeh, R.; Raki, L. 2012 Volume stability of calcium sulfoaluminate phases. The American Ceramic Society 95: 3979-3984

Kimura, K.; Ozawa, M.; Rokugo, K.; Morimoto, H. 2008. Relationship between internal vapor pressure and explosive spalling of fiber reinforced concrete, Proceedings of the Japan Concrete Institute 30 (1): 339-344.

Kostrzanowska-Siedlarz, A.; Gołaszewski, J. 2015. Rheological properties and the air content in fresh concrete for self compacting high performance concreteof Technology, Faculty of Civil Engineering, Department of Materials Engineering and Building Processes, Akademicka 5 Str., 44-100 Gliwice, Poland Construction and Building Materials 94: 555-564

Kumar, M.; Paulo, P.; Monteiro, J. M. 2005 Concrete Microstructure Properties, and Materials 3 rd edition, Department of Civil and Enviromental Engineering University of California at Berkeley

Lietuvos TSR mineralinių žaliavų apžvalga. Ats. Redakt. V. Vonsavičius. II tomas, Vilnius, $1961 \mathrm{~m}, 415 \mathrm{psl}$.

LST EN 1992-2-1-2:2005 (Eurokodas 2-1-2:2005) „Gelžbetoninių konstrukcijų projektavimas. 1-2 dalis. Bendrosios taisyklès. Konstrukcijų gaisrinès saugos projektavimas. Europos standartizacijos komitetas.

LST EN 13369 Benrosios surenkamų betoninių gaminių taisyklès. Europos standartizacijos komitetas. 
LST EN 197-1:2011 Cementas. 1 dalis. Iprastinių cementų sudètis, techniniai reikalavimai ir atitikties kriterijai. Europos standartizacijos komitetas.

LST EN 12620:2003+A1:2008 Betono užpildai. Europos standartizacijos komitetas.

LST EN 13043:2003 Keliams, skridimo aikštėms ir kitoms eismo zonoms naudojamų bituminių mišinių ir paviršiaus apdorojimo sluoksnio mineralinės medžiagos. Europos standartizacijos komitetas.

LST EN 1097-2+AC: 2003 Bandymai užpildų mechaninėms ir fizikinėms savybèms nustatyti. 2 dalis. Atsparumo trupinimui nustatymo metodai. Europos standartizacijos komitetas.

LST EN 1097-3: 2002 Užpildų mechaninių ir fizikinių savybių nustatymo metodai. 3 dalis. Piltinio tankio ir tuštymètumo nustatymas. Europos standartizacijos komitetas.

LST EN 1367-2:2010 Bandymai užpildų šiluminėms savybėms ir atsparumui atmosferos poveikiams nustatyti. 2 dalis. Magnio sulfato metodas. Europos standartizacijos komitetas.

LST EN 933-11:2009 Bandymai užpildų geometrinėms savybėms nustatyti. 1 dalis. Granuliometrinès sudèties nustatymas. Sijojimo metodas . Europos standartizacijos komitetas.

LST EN 1097-1:2011 Bandymai užpildų mechaninėms ir fizikinėms savybėms nustatyti. 1 dalis. Atsparumo dèvejjimuisi nustatymas (Devalio metodas). Europos standartizacijos komitetas.

LST EN 12350-2:2009 Betono mišinio bandymai. 2 dalis. Slankumo bandymas. Europos standartizacijos komitetas.

LST EN 12350-6:2009 Betono mišinio bandymai. 6 dalis. Tankis. Europos standartizacijos komitetas.

LST EN 12350-7:2009 Betono mišinio bandymai. 7 dalis. Oro kiekis. Slèginiai metodai. Europos standartizacijos komitetas.

LST EN 12390-3:2009 Sukietėjusio betono bandymai. 3 dalis. Bandinių gniuždymo stipris. Europos standartizacijos komitetas.

LST EN 12390-7:2009 Sukietejusio betono bandymai. 7 dalis. Sukietejusiobetono tankis. Europos standartizacijos komitetas.

LST EN 1363-1:2012 Atsparumo ugniai bandymai. 1 dalis. Bendrieji reikalavimai Europos standartizacijos komitetas.

Lukošius, K. Naujas vienpusis konstrukciju kaitinimo metodas ir jo taikymas prognozuojant atitvariniu konstrukciju atsparuma ugniai. Daktaro disertacija. VGTU, Vilnius, 2004. 100 p.

Marshall, A. L. 1972 The thermal properties of concrete. Building Science 7(3):167-174. 
Martinėnas, B. 2004. Eksperimento duomenų statistinè analizè. Vilnius: Technika. $101 \mathrm{p}$.

Martinez-Ramirez, S.; Palomo, A. 2001. Microtructure studies on portland cement pastes obtained in highly alkaline environments. Cement and Concreate Research Journal 31: 1581-1585.

Matesova, D.; Keršner, Z. 2006 Effect of porosity and fracture toughness on explosive spalling of concrete. Brittle Matrix Composites 8: 581-588.

Mendoza, O.; Tobón, J.I. 2013 An alternative thermal method for identification of pozzolanic activity in $\mathrm{Ca}(\mathrm{OH})_{2}$ /pozzolan pastes, J. Thermal Analysis Calorimetric 114: 589-596.

Min Li, Chun Xiang Qian, Wei Sun. 2004 Mechanical properties of high-strength concrete after fire. Cement and Concrete Research 34: 1001-1005.

Mindeguia, J. G.; Pimienta, P.; Noumowé, A.; Kanema, M. 2010 Temperature, pore pressure and mass variation of concrete subjected to high temperature - Experimental and numerical discussion on spalling risk. Cement and Concrete Research 40: 477- 487.

Monteagudo, S. M.; Moragues, A.; Galvez, J. C.; Casati, M. J.; Reyes, E. 2014. The degree of hydratation assessment of blended cement pastes by differential thermal and thermogravimetric analysis. Morphological evolution of the olid phases. Thermochimica Acta 592: 37-51.

Moropoulou, A.; Bakolas, A.; Aggelakopoulou, E. 2004 Evaluation of pozzolanicactivity of natural and artificial pozzolans by thermal analysis, Thermochim Acta 420: 135140.

Na-Hyun Yia,b, Seung-Jai Choia, Sang-Won Leea, Jang-Ho Jay Kim 2015. Failure behavior of unbonded bi-directional prestressed concrete panels under RABT fire loading. Fire Safety Journal 71: 123-133.

Naujokaitis, A. 2006. Statybinès medžiagos užpildai, Vilniaus Gedimino technikos universitetas. $247 \mathrm{p}$.

Naujokaitis, A. Statybinès medžiagos. Betonai. Vilnius. Technika. 2007. 355 p.

Navickas, A. A.; Skripkiūnas, G.; Gečys, R. 2003. medžiagotyros ir statybinių medžiagų laboratoriniai darbai. Kaunas: Technologija, 109 psl.

Pacewska, B.; Bukowska, M.; Wilinska, I.; Swat, M. 2002 Modification of the properties of concrete by a new pozzolan: a waste catalyst from the catalytic process in a fluidized bed, Cement Concrete Research. 32: 145-152.

Phan, L. T.; Carino, J. N. 1998 Review of Mechanical Properties of HSC at Elevated Temperature, Journal of Materials in Civil Engineering, Americal Society of Civil Engineering, Vol. 10, No. 1: 58-64. 
Pliya, P. 2011. Contribution of cocktail of polypropylene and steel fibres in improving the behaviour of high strength concrete subjected to high temperature. Construction and Building Materials 25: 1926-1934 p.

Priešgaisrinès apsaugos ir gelbejjimo departamento prie Vidaus reikalų ministerijos direktoriaus įsakymas „Dėl gaisrinès saugos pagrindinių reikalavimų patvirtinimo $2010 \mathrm{~m}$. gruodžio 7 d. Nr. 1-338.

Pundienè, I. 2000. SiO2 mikrodulkiu ịtaka mažacemenčių kaitrai atspariu betonu iš šamoto atlieku savybèms. Daktaro disetacijos santrauka. Termoizoliacijos institutas: $16 \mathrm{p}$.

Rush, D.; Bisby, L; Gillie, M.; Jowsey, A; Lane, B. 2015. Furnace tests on unprotected and protected concrete filled structural hollow sections. Fire Safety Journal 78: 71-84

Sakalauskas, V. Statistika su Statistica. Vilnius: Margi raštai, 1998. 229 p.

Sandberg, F. Doncaster, 2004 On the mechanism of strength enhancement of cementpaste and mortar with triisopropanolamine, Cement Concrete. Research. 34: 973-976.

Sarvaranta, L.; Mikkola, E. 1994 Fibre motar composites under fire conditions: effects of ageing and moisture content of specimens, Material Structure. 27: 532-538.

Schmitta, N.; Hernandeza, J. F.; Lamoura,V.; Berthauda,Y.; Meunierc,P.; Poirier, J. 2000. Coupling between kinetics of dehydration, physical and mechanical behaviour for high alumina castable. Cement and Concreate Research Journal 30: 1597-1607.

Shui, Z.; Xuan, D.; Chen, W.; Yu, R.; Zhang, R. 2009. Cementitious characteristics of hydrated cement paste subjected to various dehydration temperatures. Construction and Building Materials 23: 531-537.

Sideris, K. K.; Manita, P.; Papageorgiou, A.; Chaniotakis, E. 2006 Mechanical characteristic of high performance fiber reinforced concretes at elevated temperatures, ACI Special Publication 212-60: 973-988.

Skripkiūnas, G. Statybinių konglomeratų struktūra ir savybės. Vadovėlis. KTU. Vitae Litera. 2007. 344 p.

Soo-Ho Chang; Soon-Wook Choi; Junhwan Lee. 2016. Determination of the combined heat transfer coefficient to simulate the fire-induced damage of a concrete tunnel lining under a severe fire condition. Tunnelling and Underground Space Technology 54: 1-12.

Suhua Ma; Weifeng Li; Shenbiao Zhang; Yueyang Hu; Xiaodong Shen. 2015 Study on the hydration and microstructure of Portland cement containing diethanolisopropanolamine Cement and Concrete Research 67: 122-13.

Sun Bei; Lin Zhixiang. 2016. Investigation on spalling resistance of ultra-high-strength concrete under rapid heating and rapid cooling Case Studies in Construction Materials 4: 146-153.

Šiaučiūnas, R.; Baltakys, K.; Baltušnikas, A. Silikatinių medžiagų instrumentinè analizè. Vadovèlis. KTU. Vitae Litera. 2007. 244 p. 
Vektaris, B.; Vilkas V. Betono tvarumas. Monografija. Technologija 2006. 162 p.

Velázquez, S.; Monzó, J.; Borrachero, M. V.; Soriano, L.; Payá, J. 2016 Evaluation of the pozzolanic activity of spent FCC catalyst/fly ashmixtures in Portland cement pastes. Thermochimica Acta 632: 29-36.

Vydra, V.; Vodak, F.; Kapičkova, O.; Hoškova, Š. 2001. Effect of temperature on porosity of concrete for nuclear-safety structures, Cement and Concrete Research Journal 31:1023-1026.

Žurauskienè, R.; Naujokaitis, A. P.; Mačiulaitis, R. ir Žurauskas, R. 2012. Statybinès medžiagos. Vilnius: Technika. 540 p.

Weichung Yeih; Tun Chi Fu; Jiang Jhy Chang; Ran Huang. 2015 Properties of pervious concrete made with air-cooling electric arc furnace slag as aggregatesDepartment of Harbor and River Engineering, National Taiwan Ocean University, Keelung 202, Taiwas Construction and Building Materials 93: 737-745.

Xiao Jianzhuang; Zhiwei Li; Qinghai Xie; Luming Shen. 2016 Effect of strain rate on compressive behaviour of high-strength concrete after exposure to elevated temperatures, Fire Safety Journal. 83: 25-37

Xing, Z., Anne-Lise, B., Ronan, H., Noumowe, A., Ledesert, B. 2015. Aggregate's influence on thermophysical concrete properties at elevated temperature Construction and Building Materials Construction and Building Materials 95: 18-28.

Zoldners, N. G. 1971 Thermal properties of concrete under sustained elevated temperatures. ACI Publication SP-25: 1-31.

Бутт, Ю.; Сычев, М.; Тимашев, В. Химическая мехнология вяжущих материалов. Москва: Высшая школа, 1980. 452 с.

Ильин, Н. А. Последствия огневого воздействия на железобетонные конструксии. Москва. 1979. 212 с.

Мачюлайтис, Р. Морозостойкость и долговечность изделий фасадной керамики. Монография. Вильнюс: Техника. 1997. 307 с.

Некрасов, К. Жароупорныци ветон. Москва: Промстройиздат, 1957. 284 с.

Тейлор, Х. Химия Цемента. Москва: Мир, 1996. 215 с. 


\section{Autoriaus mokslinių publikacijụ disertacijos tema sąrašas}

Straipsniai recenzuojamuose mokslo žurnaluose

Jocius, V.; Skripkiūnas, G.; Lipinskas, D. 2013. Cement type influence on fire resistance of concrete, International Review of Civil Engineering 4(4): 162-167 (SCOPUS).

Jocius, V.; Skripkiūnas, G.; Lipinskas, D. 2014. Effect of aggregate on the fire resistance of concrete, International Review of Civil Engineering 5(4): 118-123 (SCOPUS).

Jocius, V.; Skripkiūnas, G. 2016. The mechanism of disintegration of cement concrete at high temperatures, Construction Science, 18: 4-9. 



\section{Summary in English}

\section{Introduction}

\section{Formulation of the problem}

Various types of cement concrete that may vary in cement type, aggregates and chemical admixtures, can be used in the production of reinforced concrete structures. This affects the microstructure of concrete and processes taking place at high temperatures. Concrete structure peculiarities are important in assessing the fire resistance of concrete. Currently, when designing the fire resistance of reinforced concrete structures, characteristics of concrete used in the production of the structures, materials used in production and their composition, and especially the volume of entrained air, do not receive sufficient attention.

Fire resistance of reinforced concrete structures is determined according to the thickness of the protective layer of concrete to reinforcement; however, in order to avoid additional protective layers, in case of reinforced concrete structures that are subject to high fire resistance requirements (R 180 criterion) accurate assessment of distribution of temperature fields in the concrete cross-section and proper selection of materials used to produce such concrete and its composition is necessary.

This thesis analyses the influence of cements of different types, different aggregates and entrained air content on fire resistance of concrete. 


\section{The relevance of the thesis}

One of the essential requirements that construction materials are subject to is fire resistance. In order to produce efficient reinforced concrete structures of high fire resistance, technical changes at high temperatures of concrete itself must be assessed. Raw materials for such concrete must be properly selected, quantities of components in concrete must be optimized and concrete structure resistant to high temperatures must be created optimizing concreate porosity. The results of the investigation can be applied to design fire resistant concrete structures and to produce cement concrete of increased fire resistance.

\section{The object of the research}

The object of thesis is fire resitance of concrete with various types of cement, which contain different mineral additives (blast furnace slag, limestone additives), different coarse aggregates (gravel, crushed granite, crushed dolomite, expanded clay aggregates) and different entrained air content in concrete mixture.

\section{The aim of the thesis}

To investigate the infuence of mineral additives (blast furnace slag, limestone), different mineral composition aggregates and entrained air content in concrete mixture on fire resistance of concreate.

\section{The objectives of the thesis}

1. To determine temperature distribution in the cross-section of concrete containing different cements, aggregates and entrained air content affected by high temperatures according to the standard fire curve, and to describe it mathematically.

2. To examine temperature impacts and destruction processes on concrete containing different cements and aggregates.

3. To determine changes in the microstructure and physical mechanical properties of concrete with different entrained air content under the impact of high temperatures.

4. To detarmine recommended raw materials and entrained air content in concrete when designing concreate structures with increased fire resistance.

\section{Research methodology}

Standard methods for determining slump, density and entrained air content were used to assess technological characteristics of concrete mixtures. Methods of compressive strength and ultrasonic pulse velocity were used to examine hardened concrete. To examine the distribution of temperature fields of concrete, one-way and volumetric heating methods according to a standard fire curve were used. Methods of weight loss, thermogravimetric analysis, 
infrared spectroscopy and dilatometry were used to examine the process of destruction of hardened cement paste, different aggregates and concrete. Changes in concrete microstructure were examined using a scanning electron microscopy.

\section{The scientific novelty of the thesis}

The following results important for material engineering science where obtained during investigation:

1. Temperature distribution patterns in cement concretes with different cements, aggregates and different entrained air content were determined with the temperature changing according to the standard fire curve.

2. The influence of entrained air content in concreate with air-entrained admixtures on concreate fire resistance and possibilities to use such concrete in increased fire resistance structures was determined.

\section{The practical value of the research finding}

Practical recommendations on cement type, aggregates and chemical admixtures selection for concreate were made for design of concrete with increased fire resistance.

The results can be used for the assessment of the concreate protective layer up to the reinforcement for the designed fire resistance of concreate structure considering according to mathematical equations determinated by author.

\section{The defended statements}

1. Mineral additive in cement (blast furnace slag) affecting adsorbed water content in hardened cement paste, and changes in crystalline cell occurring in aggregates, causing deformation processes in concrete during heating, have negative influence on fire resistance of concrete.

2. Increased air content in concrete up to $5 \%$ compensates temperature deformations and the pressure caused by water vapour migration under the influence of high temperature in concrete, can be used for the increasing fire resistance of concreate.

\section{The approval of the research findings}

Three scientific publications on the topic of the dissertation were published reviewed foreign journal, two of which in publications registered in Scopus database. Results of the research conducted in the dissertation were presented in five scientific conferences held in Lithuania and abroad:

- Jocius V. 2011. Cement Concrete Decomposition Mechanism at High Temperatures, $14^{\text {th }}$ conference of young scientists of Lithuania "Science - the future of Lithuania". 
- Jocius V., Skripkiūnas G., Lipinskas D. 2012. The Influence of Cement Type on Fire Resistance of Concrete. Republican conference "Materials Engineering 2012".

- Jocius V., Skripkiūnas G., Lipinskas D. 2013. The Influence of Cement Type and Different Types of Aggregates on Fire Resistance of Concrete. 54 ${ }^{\text {th }}$ international scientific conference of Riga Technical University.

- Jocius V., Skripkiūnas G., Lipinskas D. 2013. The Influence of Cement Type and Fillers on Fire Resistance of Concrete. Republican conference "Materials Engineering 2013".

- Jocius V., Skripkiūnas G., Lipinskas D. 2014. The Influence of Aggregates on Fire Resistance of Concrete. $55^{\text {th }}$ international scientific conference of Riga Technical University.

\section{The structure of the thesis}

The dissertation consists of the introduction, three chapters, general conclusions, a list of references and publications of the author of the dissertation.

The paper comprises 103 pages, excluding summary in the English language and annexes; it contains 5 numbered formulas, 60 figures and 20 tables. 108 sources of literature were used when writing the dissertation.

\section{Acknowledgements}

I want to say sincerely thank to Warsaw University of Technology Branch in Plock Chemistry institute staff, lead by Prof. Habil. Dr. Barbara Pacewska for valuable advice and performed termogravimetric and infrared spectroscopy analysis research during the scientific traineeship.

\section{Scientific research analysis of temperature influence on concrete components, structure and properties}

Hardened cement paste is a porous body with colloidal dispersible microcrystal, which can bond a relatively large amount of water, comprising the greatest part of the solid phase thereof.

The hardening of Portland cement takes place in aqueous medium saturated with calcium hydroxide $\mathrm{Ca}(\mathrm{OH})_{2}$. Cement minerals forms new hydrated compounds with water. There are three main products that form at the time of cement hydration: calcium silicate hydrates $(\mathrm{C}-\mathrm{S}-\mathrm{H})$; calcium hydroxide $(\mathrm{CH})$; calcium sulphoaluminate - in trisulfate $(\mathrm{AFt})$ or monosulfate $(\mathrm{AFm})$ form.

Scientists distinguish four stages of formation of Portland cement:

1. Having gotten into the water, cement particles start to dissolve.

2. A layer of hydration products forms on the surface of course cement particles. The finest particles become cores of hydration products. Cement particles expand when 
covered in hydrates, because the volume of hydrates is greater than the volume of cement powder.

3. Expansion results in smaller cores contacting with the surface of large particles, thus intervening and forming a cluster structure.

4. With further expansion, clusters contact in expanded places and stick together, forming a bridge structure.

Aggregate is an important component of concrete. Aggregate is an inert component of mixtures, which forms the major share of the mixture volume, up to $95 \%$. The main purpose of aggregates is to fill up the volume in the mixture, reducing the volume of a binder and improving technical properties of concrete.

To improve concrete properties, various additives are mixed in the composition of concrete. The functioning of granulated slags in cement systems is the same as that of pozzolanic additives. However, slags differ from other pozzolana, because they can harden themselves. The main product of hydration of blast furnace slag mixed with Portland cement and water was determined to be essentially exactly the same as that of Portland cement.

When hardened Portland cement paste is exposed to high temperatures, $\mathrm{Ca}(\mathrm{OH})_{2}$ calcium hydroxide, the size whereof is $10 \mathrm{~nm}$, loses water when heated and converts to $\mathrm{CaO}$ crystal of typical size of $10^{-3} \mathrm{~nm}$. The specific surface of calcium oxide is large, thus it is saturated from the environment and rehydrates. During the second hydration, the volume of $\mathrm{Ca}(\mathrm{OH})_{2}$ increases by $44 \%$. Such a phenomenon leads to complete decomposition of hardened cement paste.

When heating concrete, the explosive effect is possible. Scientists state that the explosive effect is possible at temperatures below $200{ }^{\circ} \mathrm{C}$. Other authors name temperatures of $200-350{ }^{\circ} \mathrm{C}$, say that the explosive effect is identified at this reference temperature value.

LST EN 13369:2013 standard "General rules of precast concrete products" establishes that fire resistance according to fire spread parameters may be evaluated in accordance with calculation methods or according to tests.

\section{Materials used for testing and fire resistance testing methodologies}

Portland cement with different mineral additives was used in the tests, including CEM I 42,5 R (without additives, finely ground), CEM I 42,5 N (without additives), CEM II/ALL 42,5 N (17\% limestone additive), CEM II/A-S 42,5 N (17\% blast furnace slag additive), CEM III/B 32,5 N (70 \% blast furnace slag additive), manufacturer - AB Akmenès Cementas". Chamotte "Grade-Bos 125" from the Polish company T-Ozmo. Operating temperature $-1250{ }^{\circ} \mathrm{C}, \mathrm{Al}_{2} \mathrm{O}_{3}$ content $-29 \%$. Sand, gravel, crushed granite, crushed dolomite and expanded clay aggregate was used in testing.

Concrete strength class is $\mathrm{C} 35 / 45$, which is suitable for producing load-bearing structures. S2.1 table presents composition and quantities of concrete mixture that were used to examine the infuence of mineral additives. Tests were conducted with cement with no additives, with finely ground cement, cement with $17 \%$ limestone additive and $17 \%$ and $70 \%$ slag additive. Water and cement ratio equal 0.93 . 
Table S2.1. Concrete mixtures composition (quantities for $1 \mathrm{~m}^{3}$ of concre) for testing the infuence of mineral additives

\begin{tabular}{|c|c|c|c|c|c|c|c|c|}
\hline \multirow{2}{*}{$\begin{array}{l}\text { Composi- } \\
\text { tion }\end{array}$} & \multicolumn{5}{|c|}{ Cement, kg } & \multirow{2}{*}{$\begin{array}{c}\text { Chamot } \\
\text { te (fr } \\
0 / 4), \mathrm{kg}\end{array}$} & \multirow{2}{*}{$\begin{array}{c}\text { Plasti- } \\
\text { cizer, } \\
\text { kg }\end{array}$} & \multirow{2}{*}{$\begin{array}{c}\text { Water, } \\
\mathrm{kg}\end{array}$} \\
\hline & $\begin{array}{c}\text { CEM I } \\
\mathrm{N} 42,5 \\
\mathrm{~N}\end{array}$ & $\begin{array}{c}\text { CEM } \\
\text { I R } \\
42,5 \\
\text { R }\end{array}$ & $\begin{array}{c}\text { CEM II } \\
\text { A-LL } \\
4, .5 \mathrm{~N}\end{array}$ & $\begin{array}{c}\text { CEM II } \\
\text { A-S } \\
42,5 \mathrm{~N}\end{array}$ & $\begin{array}{c}\text { CEM } \\
\text { III } / \mathrm{B} \\
32,5 \mathrm{~N} \\
-\mathrm{LH}\end{array}$ & & & \\
\hline $\begin{array}{c}\text { C1N } \\
\text { (without } \\
\text { additives) }\end{array}$ & 323 & - & - & - & - & 1896 & 6.4 & 300 \\
\hline $\begin{array}{l}\text { C1R (fine- } \\
\text { ly gound) }\end{array}$ & - & 323 & - & - & - & 1896 & 6.4 & 300 \\
\hline $\begin{array}{c}\text { C2L (17\% } \\
\text { limestone } \\
\text { additive) }\end{array}$ & - & - & 323 & - & - & 1896 & 6.4 & 300 \\
\hline $\begin{array}{l}\text { C2S (17\% } \\
\text { slag addi- } \\
\text { tive) }\end{array}$ & - & - & - & 323 & - & 1896 & 6.4 & 300 \\
\hline $\begin{array}{c}\text { C3 }(70 \% \\
\text { slag addi- } \\
\text { tive })\end{array}$ & - & - & - & - & 323 & 1896 & 6.4 & 300 \\
\hline
\end{tabular}

S.2.2 table illustrates the composition of concrete mixture and quantities, which were used to investigate the infuence of aggregates. The tests were conducted with gravel, crushed dolomite, crushed granite and expandet clay aggregates.

Table S2.2. Concrete mixtures composition (quantities for $1 \mathrm{~m}^{3}$ of concrete) for testing of the infuence of aggretates

\begin{tabular}{|c|c|c|c|c|c|c|c|c|c|c|}
\hline \multirow{3}{*}{ 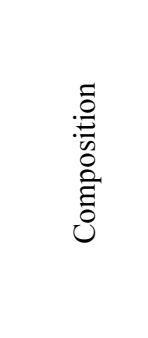 } & \multicolumn{2}{|c|}{ Cement, kg } & \multicolumn{6}{|c|}{ Aggregate, $\mathrm{kg}$} & \multirow{3}{*}{ 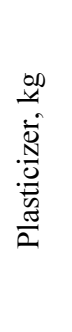 } & \multirow{3}{*}{ 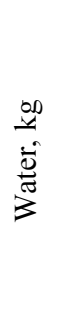 } \\
\hline & \multirow{2}{*}{ 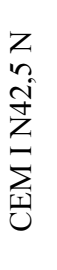 } & \multirow{2}{*}{ 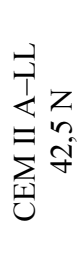 } & \multirow{2}{*}{ 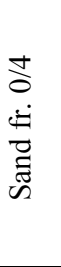 } & \multirow{2}{*}{ 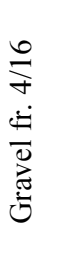 } & \multirow{2}{*}{ 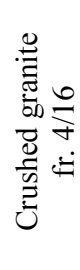 } & \multirow{2}{*}{ 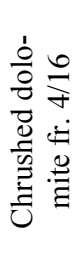 } & \multicolumn{2}{|c|}{ 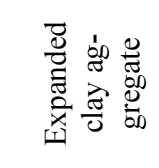 } & & \\
\hline & & & & & & & $\begin{array}{c}\text { fr. } \\
4 / 8\end{array}$ & $\begin{array}{c}\text { fr. } \\
4 / 8\end{array}$ & & \\
\hline 1 & 2 & 3 & 4 & 5 & 6 & 7 & 8 & 9 & 10 & 11 \\
\hline $\begin{array}{c}\text { U1Ž } \\
\text { (gravel) }\end{array}$ & 331 & - & 856 & 1020 & - & - & - & - & 3.31 & 149 \\
\hline $\begin{array}{c}\mathrm{U} 1 \mathrm{G} \\
\text { (granite) }\end{array}$ & 331 & - & 856 & - & 1020 & - & - & - & 3.31 & 149 \\
\hline $\begin{array}{c}\text { U1D } \\
\text { (dolomite) }\end{array}$ & 331 & - & 856 & - & - & 1020 & - & - & 3.31 & 149 \\
\hline
\end{tabular}


End of the Table S2.2

\begin{tabular}{|c|c|c|c|c|c|c|c|c|c|c|}
\hline 1 & 2 & 3 & 4 & 5 & 6 & 7 & 8 & 9 & 10 & 11 \\
\hline $\begin{array}{c}\text { U1K (ex- } \\
\text { panded } \\
\text { clay }\end{array}$ & 331 & - & 856 & - & - & - & 92 & 112 & 3.31 & 149 \\
\hline $\begin{array}{c}\text { U2Ž } \\
\text { gravel) }\end{array}$ & - & 331 & 856 & 1020 & - & - & - & - & 3.31 & 149 \\
\hline $\begin{array}{c}\text { U2G } \\
\text { granite) }\end{array}$ & - & 331 & 856 & - & 1020 & - & - & - & 3.31 & 149 \\
\hline $\begin{array}{c}\text { U2D (do- } \\
\text { lomite) }\end{array}$ & - & 331 & 856 & - & - & 1020 & - & - & 3.31 & 149 \\
\hline $\begin{array}{c}\text { U2K (ex- } \\
\text { panded } \\
\text { clay) }\end{array}$ & - & 331 & 856 & - & - & - & 92 & 112 & 3.31 & 149 \\
\hline
\end{tabular}

S2.3. table presents composition of concrete mixture and quantities that were used to test the infuence the entrained air content on concrete fire resistance.

Table S2.3. Concrete mixtures composition (quantities for $1 \mathrm{~m}^{3}$ of concre) for testing of the infuence of entrained air content

\begin{tabular}{|c|c|c|c|c|c|c|}
\hline \multirow[t]{2}{*}{ Composition } & \multirow{2}{*}{$\begin{array}{c}\text { Cement, } \\
\text { kg }\end{array}$} & \multicolumn{2}{|c|}{ Aggregate, $\mathrm{kg}$} & \multirow{2}{*}{$\begin{array}{l}\text { Plasti- } \\
\text { cizer, } \\
\text { kg }\end{array}$} & \multirow{2}{*}{$\begin{array}{l}\text { Air- } \\
\text { entrain- } \\
\text { ing } \\
\text { admix- } \\
\text { ture, \% }\end{array}$} & \multirow{2}{*}{$\begin{array}{c}\text { Water, } \\
\text { kg }\end{array}$} \\
\hline & & $\begin{array}{l}\text { Sand fr. } \\
0 / 4\end{array}$ & $\begin{array}{c}\text { Chrushed } \\
\text { dolomite } \\
\text { fr. } 4 / 16\end{array}$ & & & \\
\hline $\begin{array}{l}\mathrm{O} \text { (entrained air } \\
\text { content } 3.2 \% \text { ) }\end{array}$ & 331 & 856 & 1020 & 3.31 & 0.0 & 149 \\
\hline $\begin{array}{l}\mathrm{O}-01 \text { (entrained air } \\
\text { content } 4.0 \% \text { ) }\end{array}$ & 331 & 856 & 1020 & 3.31 & 0.1 & 149 \\
\hline $\begin{array}{l}\mathrm{O}-02(\text { entrained air } \\
\text { content } 5.0 \% \text { ) }\end{array}$ & 331 & 856 & 1020 & 3.31 & 0.2 & 149 \\
\hline $\begin{array}{l}\mathrm{O}-03(\text { entrained air } \\
\text { content } 10.0 \% \text { ) }\end{array}$ & 331 & 856 & 1020 & 3.31 & 0.3 & 149 \\
\hline $\begin{array}{l}\mathrm{O}-06(\text { entrained air } \\
\text { content } 14.0 \%)\end{array}$ & 331 & 856 & 1020 & 3.31 & 0.6 & 149 \\
\hline $\begin{array}{c}\mathrm{O}-03 \mathrm{P} \text { (entrained air } \\
\text { content } 8.5 \%)\end{array}$ & 460 & 856 & 1020 & 4.6 & 0.3 & 149 \\
\hline $\begin{array}{c}\mathrm{O}-06 \mathrm{P} \text { (entrained air } \\
\text { content } 12.0 \% \text { ) }\end{array}$ & 520 & 856 & 1020 & 5.2 & 0.6 & 149 \\
\hline
\end{tabular}

$100 \mathrm{~mm} \times 100 \mathrm{~mm} \times 100 \mathrm{~mm}$ concrete cubes were produce for the experiments. Slump of the concrete mixture was determined according to LST EN 12350-2, its density - according to LST EN 12350-6, and entrained air content in the mixture - according 
to LST EN 12350-7. Before tests, concrete cubes were cured in water of $20 \pm 2{ }^{\circ} \mathrm{C}$ for 28 days. 12 pcs. samples were made in each batch. Three samples from each batch were used to determine compressive strength after 28 days. Compressive strength of concrete was determined according to LST EN 12390-3. The density of hardened concrete was determined according to LST EN 12390-7 requirements.

Concrete cubes of different mixtures were formed for application of one-sided fire resistance testing method. Four edges of the cube were insulated in mineral wool and the other two were not insulated. One uninsulated edge of the cube was pressed to the furnace. Figure S2.1 illustrates the principal scheme of the evaluation methodology of oneside heating.

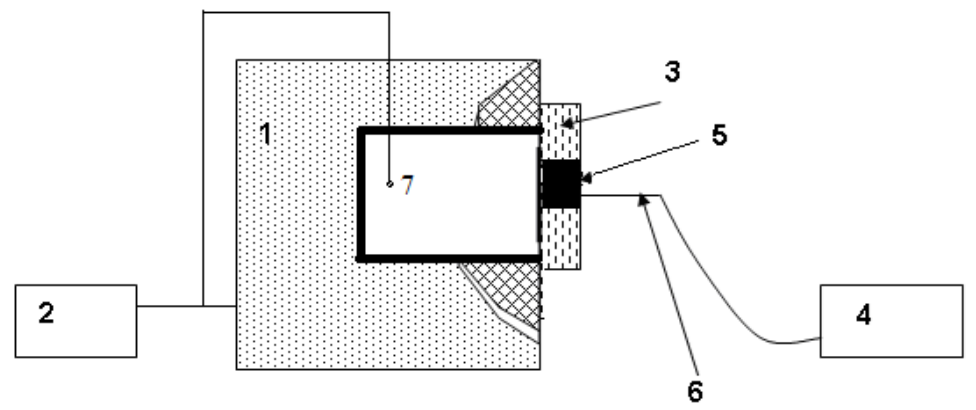

Fig. S2.1. The principal scheme of the one-side heating equipment that was used for one side heating tests: 1 - electric oven; 2 - electric oven heating control unit; 3 - sample storage device with mineral wool insulating; 4 -temperature recorder; 5 -specimen, 6 - measuring thermocouple K type, 7 - thermocouple of oven

Concrete cubes of different mixtures were formed for application of volumetric fire resistance testing method. One edge of the cube was insulated from thermal effects, and the other five were left uninsulated. A concrete cube was easily placed into the furnace on the insulating plate. Figure S2.2 illustrates the principal scheme of the volumetric fire resistance testing method.

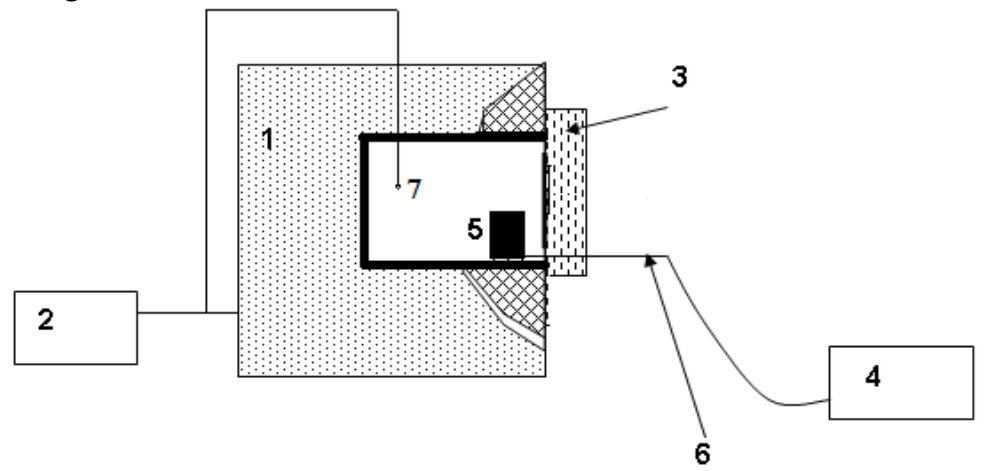

Fig. S2.2. The principal scheme of the volumetric heating equipment that has been used for volumetric heating tests: 1 - oven; 2 - oven heating control unit; 3 - door of chamber; 4 temperature recorder; 5 - specimen, 6 - measuring thermocouple $\mathrm{K}$ type, 7 - thermocouple of oven 
The principle of the experiment is to heat the sample from one or all sides as provided for in the LST EN 1363-1:2012 standard according to the regulated temperature time dependence. In addition to the above-listed tests, thermogravimetry of hydrated cement paste and aggregates as well as measurements of weight losses and changes in the ultrasonic pulse velocity propagation speed were performed, compressive strength, also conducting concrete dilatometric research and microstructure analysis using scanning electronic microscopy.

\section{Type of cement, aggregates and the amount of air influence on concrete exposured to elevated high temperatures fracture processes}

Figure S3.1 illustrates compressive strength of concrete affected by temperature mode according to a one-sided method of evaluation of fire resistance with different cements.

The presented figure S3.1 illustrates that the greatest reduction in the compressive strength after heating was observed with cement containing $17 \%$ of slag, and was $30.5 \%$. A sample with cement with $70 \%$ slag content disintegrated by way of explosive spalling in 30 minutes, and lost $18.8 \%$ of compressive strength; it is estimated that having continued the experiment for up to 3 hours, the sample would have disintegrated in full. Concrete samples with cement containing 17\% limestone additive lost the least (12.5\%) compressive strength. These results can be explained by the conducted dilatometric tests presented in Figure S3.2.

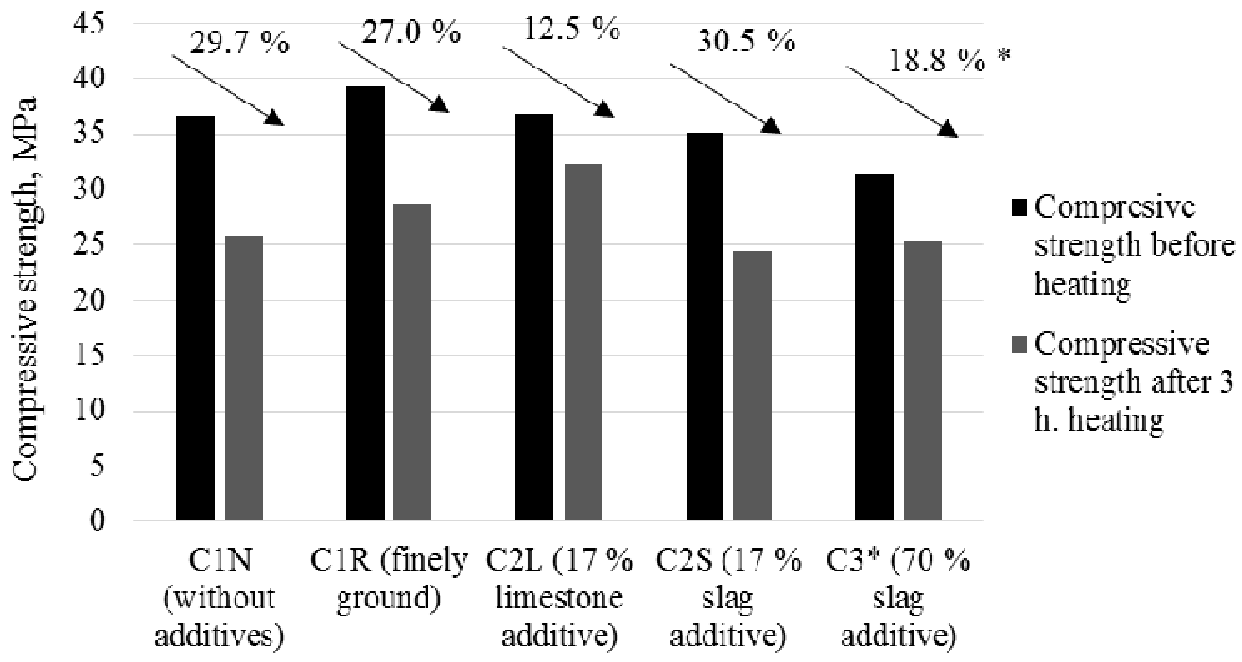

Fig. S3.1. Concrete compressive strength of samples with different cements.

* - explosive spalling, result after $30 \mathrm{~min}$. 


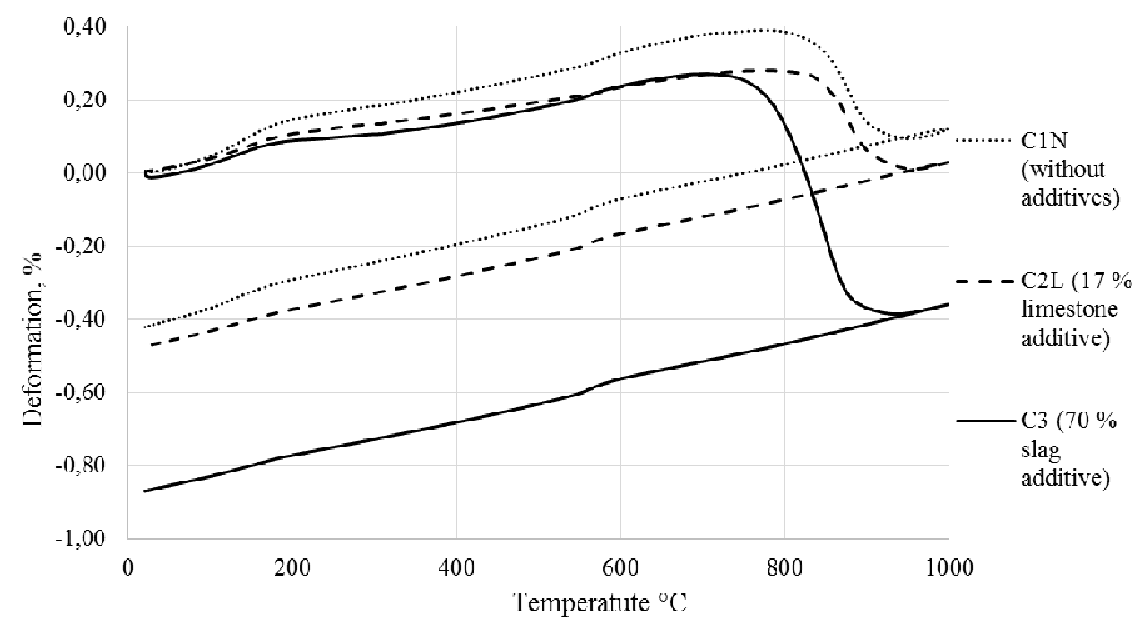

Fig. S3.2. Concrete samples thermal expansion and shrinkage with different cements

The presented Fig. S3.2 illustrates different deformations of concrete samples with different mineral additives. The greatest deformations were observed in concrete samples with $70 \%$ slag additive, which account for about $1 \%$ in total. The lowest deformations were captured in concrete samples with $17 \%$ limestone additive, accounting for about $0.5 \%$. These results allow stating that concrete with cement containing $17 \%$ limestone additive is more resistant to temperature effects.

Fig. S3.3 illustrates compressive strength of concrete under the influence of temperature mode according to a one-side fire resistance evaluation method, with different aggregates.

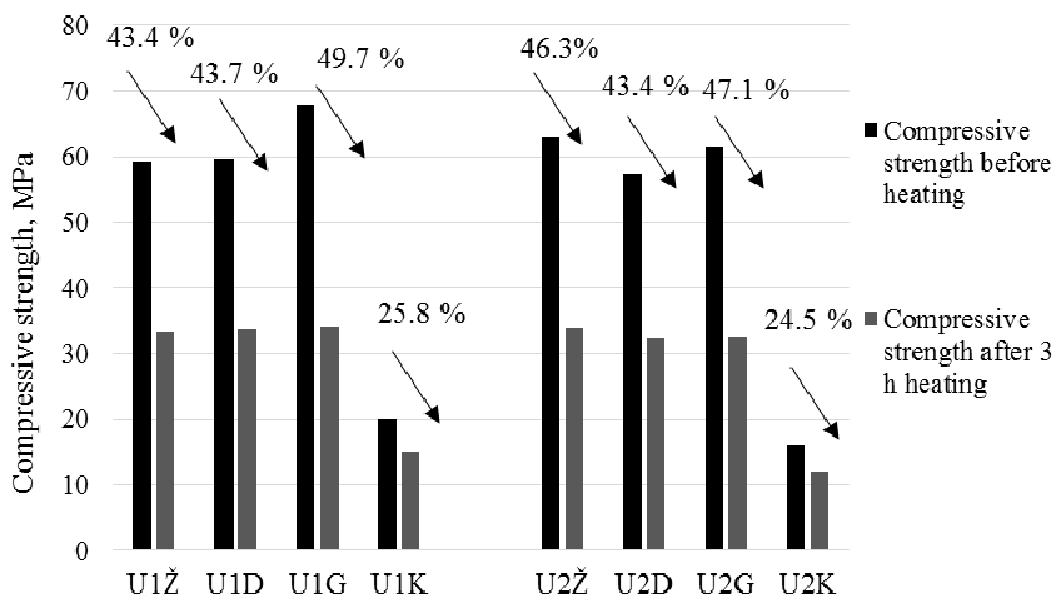

Fig. S3.3. Concrete compressive strength decrease of samples after one side heating with different aggregates 
The obtained results reveal that the greatest reduction in compressive strength was captured in concrete samples with granite aggregate accounting for $49.7 \%$ (with cement without additives) and $47.1 \%$ (with cement containing $17 \%$ limestone additives). Better results were captured with expanded clay aggregate, where the decrease in compressive strength accounted for $25.8 \%$ (with cement without additives) and $24.5 \%$ (with cement containing $17 \%$ limestone additives). These results may be explained by thermogravimetric and dilatometric tests illustrated in Figures S3.4 and S3.5.

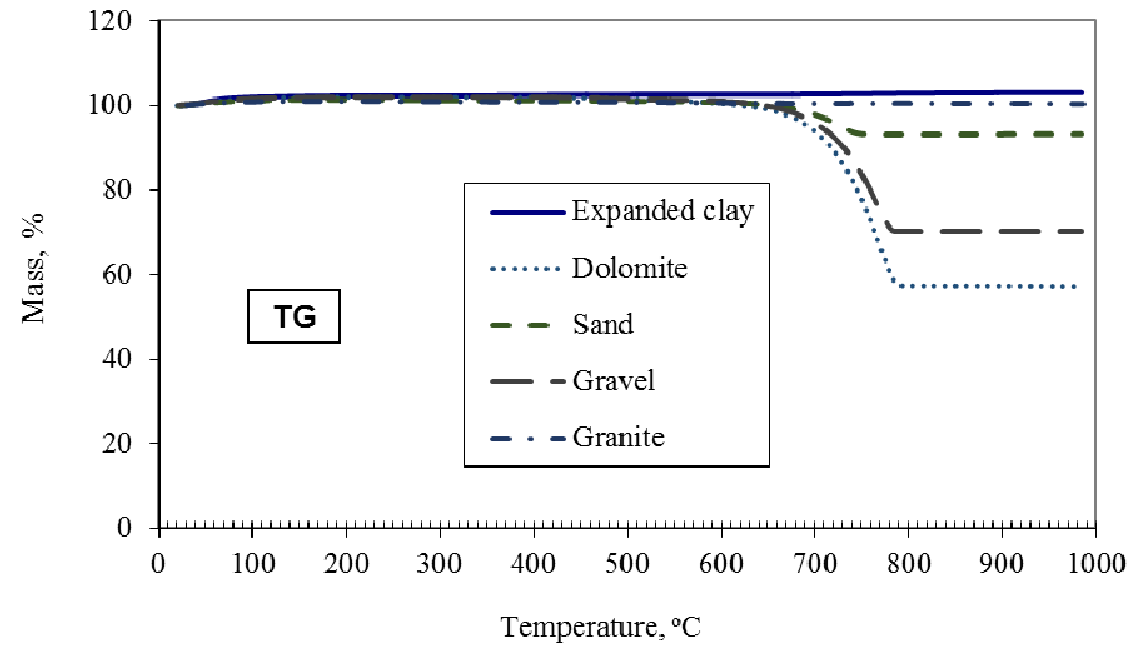

Fig. S3.4. Termogravimetric curves of different type of aggregates

Curves illustrating weight loss presented in Figure S3.4. show that no temperature decomposition takes place in expanded clay and granite aggregates, but weight losses were captured in sand, gravel and dolomite. Calcium and magnesium carbonates decompose at $650-800{ }^{\circ} \mathrm{C}$, which affects mechanical properties of concrete.

Figure S3.5 illustrates different deformation of concrete samples with different aggregates. The greatest deformation were captured in concrete samples with crushed granite aggregate accounting for about $1.8 \%$. The lowest deformations were captured in concrete samples with expanded clay aggregate accounting for about $0.9 \%$. These results allow stating that concrete with expanded clay aggregate is more resistant to temperature effects; when it comes to heavy aggregates, lowest deformations were captured with crushed dolomite aggregate.

Figure S3.6 illustrates concrete compressive strength affected by temperature mode according to a one-side fire resistance testing method with different entrained air content. Data presented in Figure S3.6. reveals that the worst results were captured with concrete with the lowest air content of $3.2 \%$ (concretw without air entrained admixture). Compressive strength decreased by $44.9 \%$. The best results were achieved with the greatest air content (14\%), when the compressive strength decreased by $26.4 \%$. 


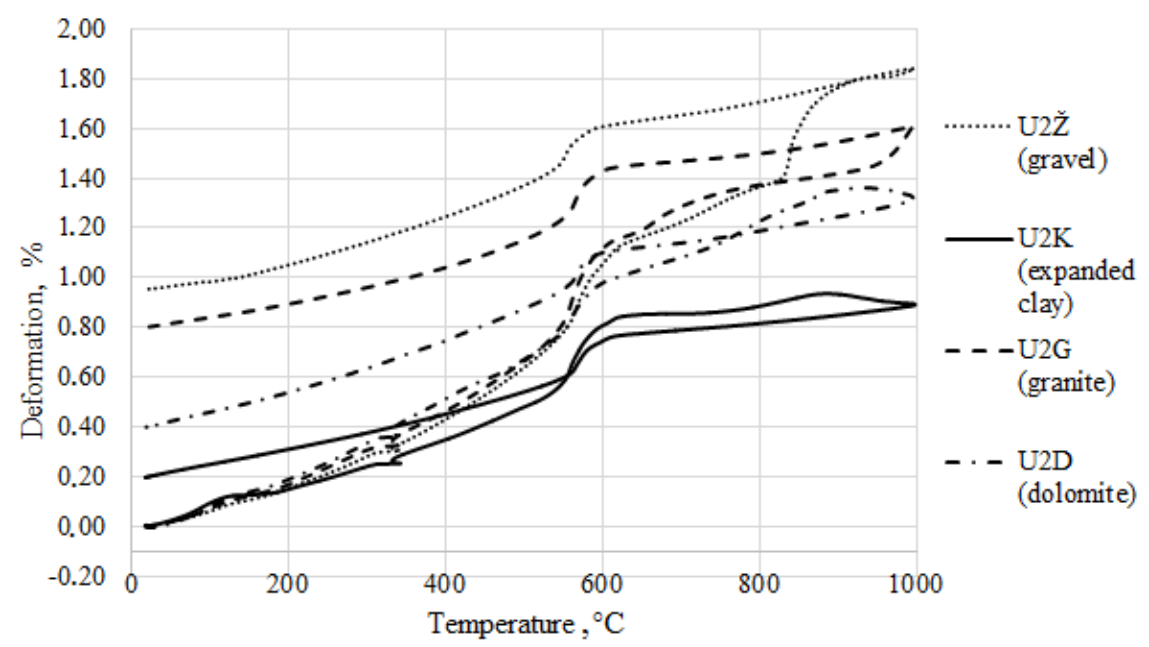

Fig. S3.5. Thermal expansion and shrinkage of concrete samples with different aggregate

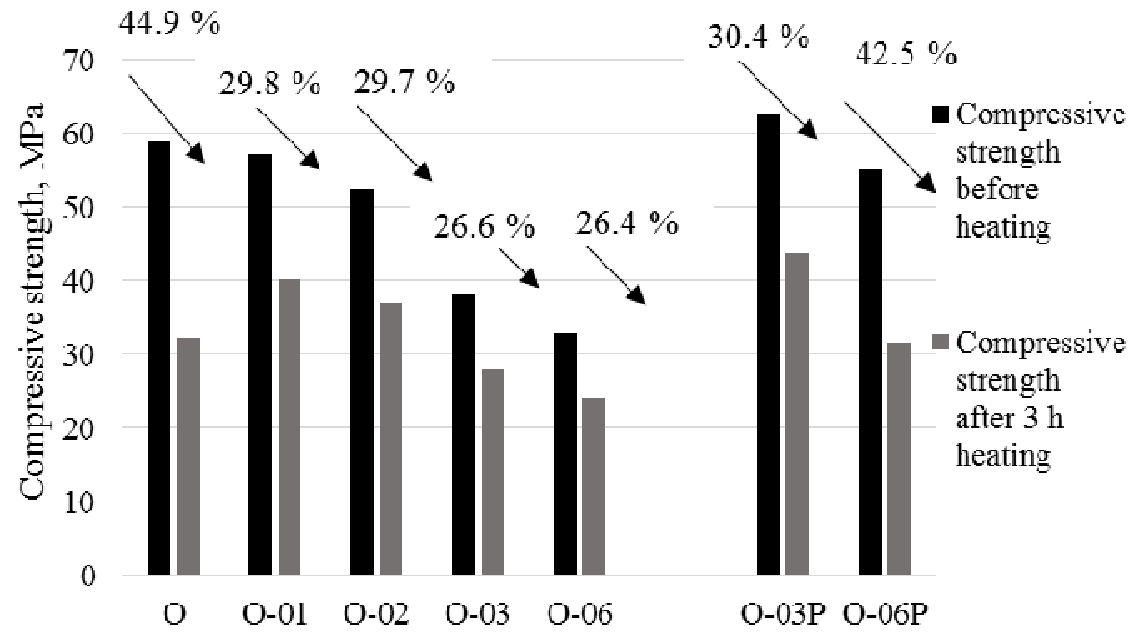

Fig. S3.6. Compressive strength before and after heating of concrete samples with different entrained air content

Figure S3.7 presents photos of microstructure of heated surface of concreate with different content of entrained air.

Figure S3.7 illustrates that surface particles of samples without air entraining admixtures (air content 3.2\%) started chipping off and crumbling of the sample after 3 hours of heating. Deep cracks formed in samples with $0.2 \%$ air-entraining admixture (air content 5\%), while surface of samples with 14\% air content changed the least, with 
shallow cracks. Such effect could be explained by the fact that water vapour spread to larger pores, forming lower pressure and lower stresses.

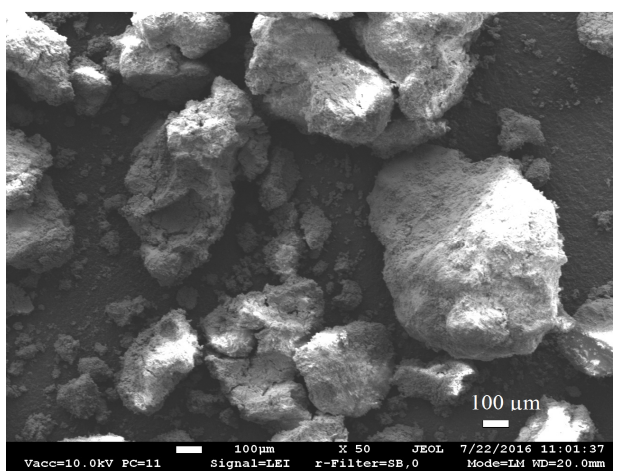

a)

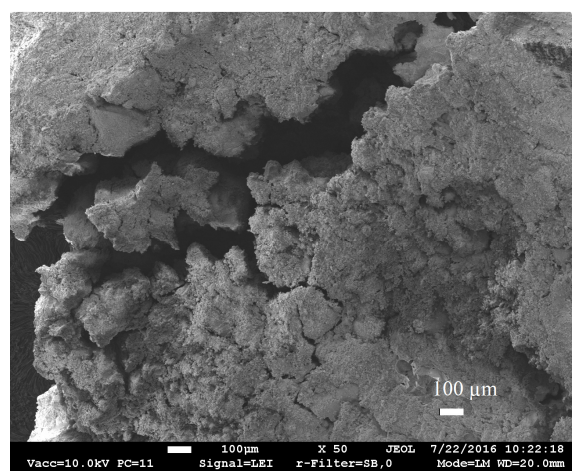

b)

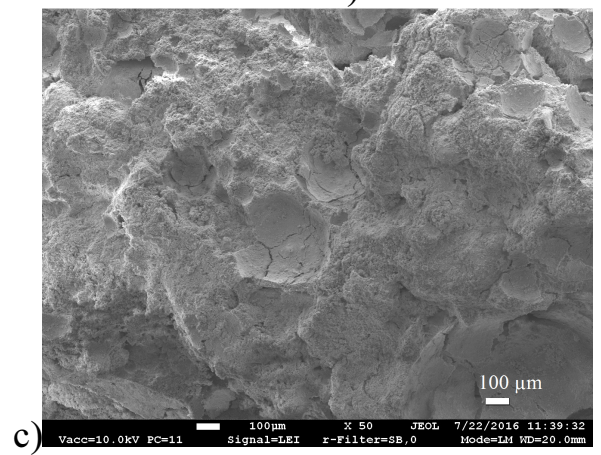

Fig. S3.7. Concrete samples with different content of entrained air surface microstructure:

a) $3.2 \%$; b) $5.0 \%$; c) $14 \%$

Temperature curves obtained during the experiments allow accurately describing the dependences received by polynomic functions. Having conducted regression analysis, empirical equations were drawn up, which allow forecasting concrete temperature $\left(\mathrm{T},{ }^{\circ} \mathrm{C}\right)$ after the chosen heating duration $(\tau, \mathrm{min})$ at the selected distance from the heating surface $(\mathrm{a}, \mathrm{cm})$.

$$
\begin{aligned}
& \mathrm{T}=439+8.3 \tau-0.025 \tau^{2}-226 \mathrm{a}+25 \mathrm{a}^{2}-0,14 \tau \mathrm{a} \\
& \mathrm{T}=435+8.3 \tau-0.025 \tau^{2}-227 \mathrm{a}+25 \mathrm{a}^{2}-0,19 \tau \mathrm{a}
\end{aligned}
$$

The equation (S.1) is used when no air-entraining admixture was added in concrete, while the equation (S.2) is used when air-entraining admixture was added to the mixture.

Figures S3.8 respectively, present a graphic polynomial dependence according to S.2 empirical equations. Since the critical temperature of steel at the time of the fire is $500{ }^{\circ} \mathrm{C}$, it is important that concrete does not reach this temperature for as long as possible. 


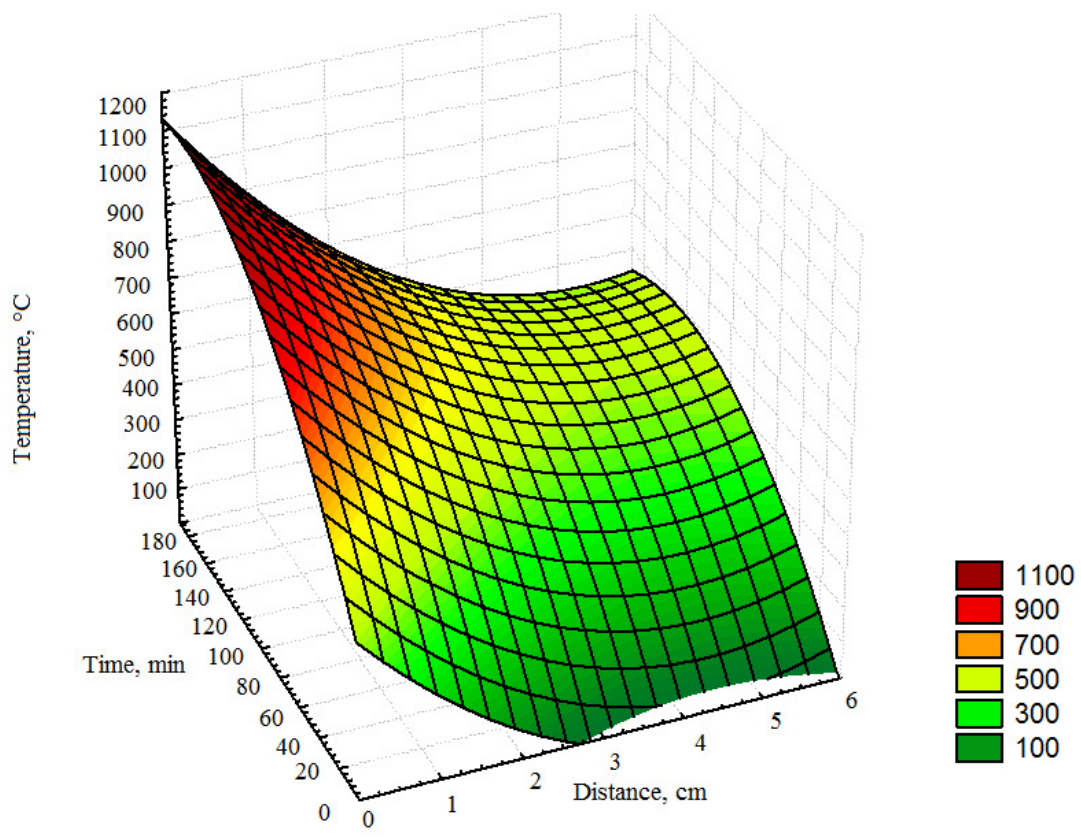

Fig. S3.8. Temperature dependence on time and distance from the surface of the test in accordance with S.2 empirical formula

The results of investigation shows the tested concrete in $5 \mathrm{~cm}$ distance from heated surface after $180 \mathrm{~min}$ don't receive critical temperature equal to $500{ }^{\circ} \mathrm{C}$ when entrained air content in concreate is more than $4 \%$, in $3 \mathrm{~cm}$ distance from heated surface this temperature don't receive after $100 \mathrm{~min}$ and in $2 \mathrm{~cm}$ distance from heated surface after $60 \mathrm{~min}$.

\section{General conclusions}

1. Cement containing limestone additive (CEM II A-LL type) is most suitable for concrete resistant to temperature effects. Measurements of temperature fields of concreate with cements with different mineral additives at a distance of $5 \mathrm{~cm}$ from the heated surface in 3 hours of impact according to a standard fire curve reveal that the lowest temperature (lower by about $24^{\circ} \mathrm{C}$ ) is achieved and lowest losses in compressive strength of concrete with cement containing limestone additive after thermal effect account for $12.5 \%$, while concrete with other cements loses $27.0 \%$ $30.5 \%$ of strength. The received results can be explained by lower adsorbed water content in hardened cement paste and destruction of carbonate additive at higher 
temperature than calcium silicate hydrates, composed after clinker hydration process.

2. Expanded clay aggregate has an advantage in terms of fire resistance compared to other aggregates. The reduction of the compressive strength of concrete expanded clay aggregate decreases by about $25-26 \%$ with different aggregates accounts for $43-49 \%$. The received results can be explained by lower thermal deformations of concreate with this aggregate. Having conducted temperature distribution tests with different concrete aggregates according to the standard fire curve, it turned out that the lowest temperature at the distance of $5 \mathrm{~cm}$ was achieved with dolomite aggregate, which was $531{ }^{\circ} \mathrm{C}$ in case of cement without additives and $509{ }^{\circ} \mathrm{C}$ in case of cement with limestone additive.

3. Having increased enrained air content in concrete mixture up to $4-5 \%$, the loss of compressive strength after thermal effects decreases significantly: from $44.9 \%$, when entrained air content is $3.2 \%$ (concrete without air-entraining admixture), to $29.8 \%$, when entrained air content is $4.0 \% ; 29.7 \%$, when entrained air content is $5 \%$; $26.6 \%$, when entrained air content is $10 \%$, and $26.4 \%$, when entrained air content is $14 \%$. Tests of temperature fields in concrete samples with different entrained air content reveal that temperature is by about $31{ }^{\circ} \mathrm{C}$ lower at the distance of $5 \mathrm{~cm}$ from the heated surface in concrete with $5 \%$ entrained air content compared to concrete without air-entraining admixture. The received results can be explained by high closed porosity level of concrete, which compensates the forming internal stresses and water vapour pressure at the time of exposure to heat.

4. The best results in terms of fire resistance of concrete were achieved with cement containing limestone additive, coarse dolomite aggregate and 5\% entrained air content. After temperature impact according to the standard fire curve, such concrete loses $29.7 \%$ of its compressive strength after 3 hours of heating. Temperature value of concrete at the distance of $5 \mathrm{~cm}$ from the heated surface stays below $480{ }^{\circ} \mathrm{C}$. Having increased air content in concrete mixture up to $5 \%$ the reinforced concrete structures can by produce with $5 \mathrm{~cm}$ concrete protective layer and fire resistance corresponded to REI 180.

5. The empirical equations obtained with the help of test results of the one-side heated cube specimens can be used for predicting temperature distribution within the concrete cover. These equations could enable a more accurate assessment of the required cover thicknes in reinforced concrete structures. 



\section{Priedai $^{3}$}
A priedas. Disertacijos autoriaus sąžiningumo deklaracija B priedas. Bendraautorių sutikimai teikti publikacijose skelbtą medžiagą mokslo daktaro disertacijoje C priedas. Autoriaus mokslinių publikacijų disertacijos tema kopijos

${ }^{3}$ Priedai pateikiami pridètoje kompaktinejje plokštelëje. 
Vytautas JOCIUS

CEMENTO TIPO, UŽPILDU IR ORO KIEKIO MIŠINYJE ITAKA BETONO ATSPARUMUI UGNIAI

Daktaro disertacija

Technologijos mokslai, medžiagų inžinerija (08T)

CEMENT TYPE, AGGREGATES AND AIR CONTENT IN CONCRETE MIXTURE INFLUENCE ON THE FIRE RESISTANCE OF CONCRETE

Doctoral Dissertation

Technological Sciences,

Materials Engineering (08T)

201707 18. 11,5 sp. I. Tiražas 20 egz.

Vilniaus Gedimino technikos universiteto

leidykla "Technika“,

Saulètekio al. 11, 10223 Vilnius,

http://leidykla.vgtu.lt

Spausdino BI UAB „Baltijos kopija“

Kareivių g. 13B, 09109 Vilnius 